Photograph courtesy of: OREGON HISTORICAL SOCIETY

From "Souvenir Views of Portland"s Great Flood-June 1894" Published by Peasley Bros. Portland. 
Photograph courtesy of:

OREGON HISTORICAL SOCIETY

From "Souvenir Views of Portland's Great Flood-June 1894"

Published by Peasley Bros. Portland. 


\section{Storm Runoff As Related To Urbanization in the Portland, Oregon- Vancouver, Washington Area}

By Antonius Laenen

U.S. GEOLOGICAL SURVEY

Water Resources Investigations

Open-File Report 80-689

Prepared in cooperation with the

City of Portland, Multnomah County, Oregon,

Clark County, Washington, and U.S. Army Corps of Engineers

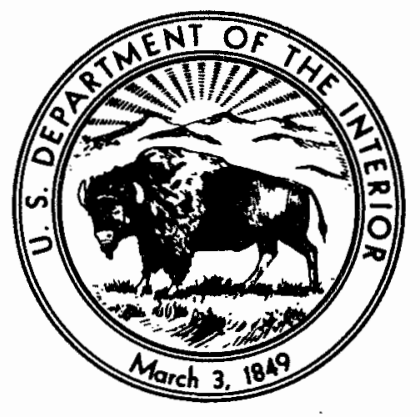




\section{UNITED STATES DEPARTMENT OF THE INTERIOR \\ CECIL D. ANDRUS, Secretary GEOLOGICAL SURVEY \\ H. William Menard, Director}

For additional information write to:

U.S. GEOLOGICAL SURVEY

P.O. Box 3203

Portland, Oregon 97208 


\section{Contents}

Conversion factors

Glossary -

Abstract

Introduction-1.2.

Rainfa11-runoff processes-1.

Problem-

Present solution-1.- 3

Solution used in this study-a 3

Acknowledgments-1. 3

Physical setting-1

Geography--

East Portland-1and 4

West Portland--

Vancouver-1.. 6

Drainage systems-1.. 6

Rainfa11 characteristics-_. 7

Data-collection methods-_... 10

Rainfal1-runoff data collection network-1

Basin characteristics-_... 10

Description of the hydrologic analyses used-16

Digital model calibration--16

Digital model simulation-

Mode1 verification--..- 21

Peak- and storm-runoff frequency analyses-_.

Storm base flow- 27

Lag-time relations-- 29

Uniqueness of selected basins

Ke11y Creek-1. 30

Vancouver sewer-1. 30

Beaverton Creek-1. 30

Beaverton Creek tributary-a. 31

Butternut Creek-1.

Singer Creek-1.-.

Kellogg Creek, Vancouver Lake tributary, and Cougar Creek-.-.-...-.- 32

Tryon Creek tributary-

Sa1tzman Creek-1.

Regionalization of flood-peak and storm-runoff characteristics-_....... 32

Example--

Sensitivity-1... 37

Assessment of peak discharges for historic extremes prior to period

of study-- peak discharges for historic extremes prior to period 39

Conclusions -

Selected references-10 70 


\section{Illustrations}

Page

Plate 1. Topographic map showing gage locations and basin boundaries-_-___- In pocket

Figure 1. Map showing geography of Portland - Vancouver area-_-_-__-_-_-_ 4

2. Isopluvial map of 0.02 exceedance probability, 6-hour precipitation

3. Rainfall-intensity curves for U.S. Customs House, Portland, Oreg.

4. Graph showing distribution of drainage area in relation to impervious area-_-_-__- 11

5. Graph showing distribution of drainage area in relation to average basin slope

6. Graph showing determination of effective impervious area by digital model

7. Example of scatter diagram of model results for storm runoff-

8. Example of scatter diagram of model results for peak

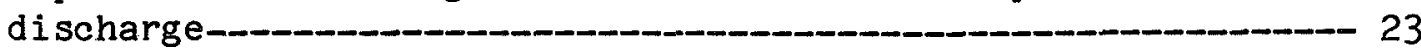

9. Computer printout showing storm rainfall and discharge hydrograph-__-__- 24

10. Scatter diagram of Johnson Creek model verification--_-_-_--_--- 25

11. Graph showing relation of lag time to length-slope ratio - - -

12. Bar graph showing residuals of peak discharge for individual basins-_-_-_-_-__- 34

13. Bar graph showing residuals of storm runoff for individual basins-_-_-_-_-_- 35

14. Graph showing sensitivity of storage in basins__________- 39

15. Graph showing relation of maximum 24-hour precipitation to peak discharge for Johnson Creek-__ 40

16. Graph showing relation of maximum 1-hour precipitation to peak discharge for Fanno Creek____ 42

17. Log-Pearson Type III frequency curves for Johnson Creek 


\section{Tables}

Page

Table 1. Drainage-basin characteristics-_- 13

2. Identification and definition of parameters used in the digital model-__-_- 17

3. Calibrated model parameters used for synthesis of discharge peaks and storm runoff-__- 19

4. Peak discharge for selected flood frequencies and

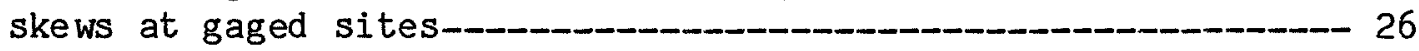

5. Peak discharge yields and storm runoff for selected flood frequencies at gaged sites-_- 28

6. Sensitivity analysis of parameters in regression

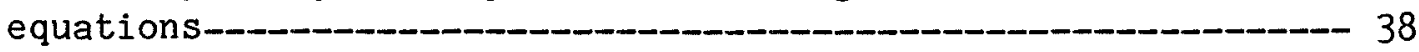

7. Summary of statistics for regression analysis of peak discharge for selected exceedance probabilities (recurrence intervals)

8. Summary of regression-equation coefficients and exponents for peak discharge for selected exceedance probabilities (recurrence intervals) -

9. Summary of statistics for regression analysis of storm runoff without base flow for selected exceedance probabilities (recurrence intervals)-_-_-_-_-_-_ 47

10. Summary of regression-equation coefficients and exponents for storm runoff without base flow for selected exceedance probabilities (recurrence intervals)

11. Summary of statistics for regression analysis of storm runoff with base flow for selected exceedance probabilities (recurrence intervals)

12. Summary of regression-equation coefficients and exponents for storm runoff with base flow for selected exceedance probabilities (recurrence intervals)

13. Daily precipitation (computer printouts)

14. Selected storm data-_ 62 


\section{CONVERSION FACTORS}

[For use of those readers who may prefer to use metric units rather than inch-pound units, the conversion factors for the terms used in this report are listed below: ]

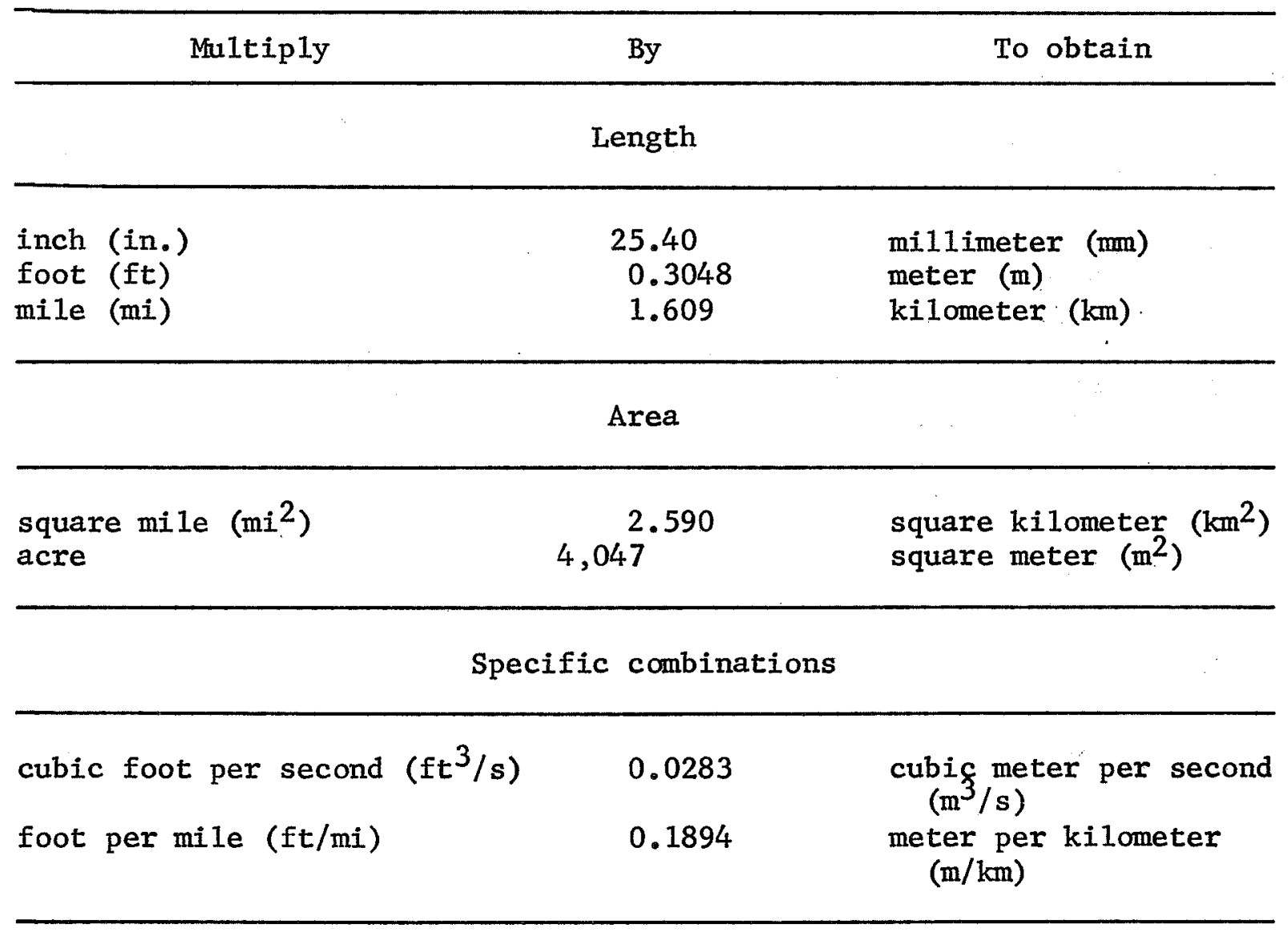




\section{GLOSSARY}

Exceedance probability.--Probability that a random event will exceed a specific magnitude in a given time period. For example, a flood with a 0.01 exceedance probability is a flood that has one chance in a hundred of being exceeded in any one year. This is a 100-year flood under the "recurrence-interva1" terminology. In this report, the term "exceedance probability" is used in preference to the term "recurrence interval." Both terms, however, are used in most of the tables, graphs, and illustrative problems.

R-square.--The coefficient of determination. It is a measure of the variation explained by the regression equation. R-square $\times 100$ yields the percent of variation explained. If $R$-square $=1$, then 100 percent of the variation is explained by the equation; if $\mathrm{R}$-square $=0.75$, then 75 percent of the variation is explained by the equation. It is a "best-fit" test for the population scatter about a curve.

"F" statistic.--A test that defines the significance of the independent variables. The larger the "F" value, the more significance it has in the equation. Unless otherwise shown, all "F" statistics fal1 within the 95-percent confidence 1imit.

Standard error of estimate (SEE).--A statistical measure of accuracy based on population scatter about the curve only. It is the square root of the variance and is graphically defined as having two-thirds of the data points falling within its limits.

Detention storage.--Storage of storm runoff from roofs, parking lots, and other impervious surfaces especially designed to reduce peak flows. Detention-storage areas normally have constricted outlets so that water will flood designated areas and flow out slowly, thereby reducing the effective flood peak.

Effective impervious area (EIA).--The area, as a percentage of total drainage area, having a direct hydraulic link to the stream and impervious to the infiltration of rain. 


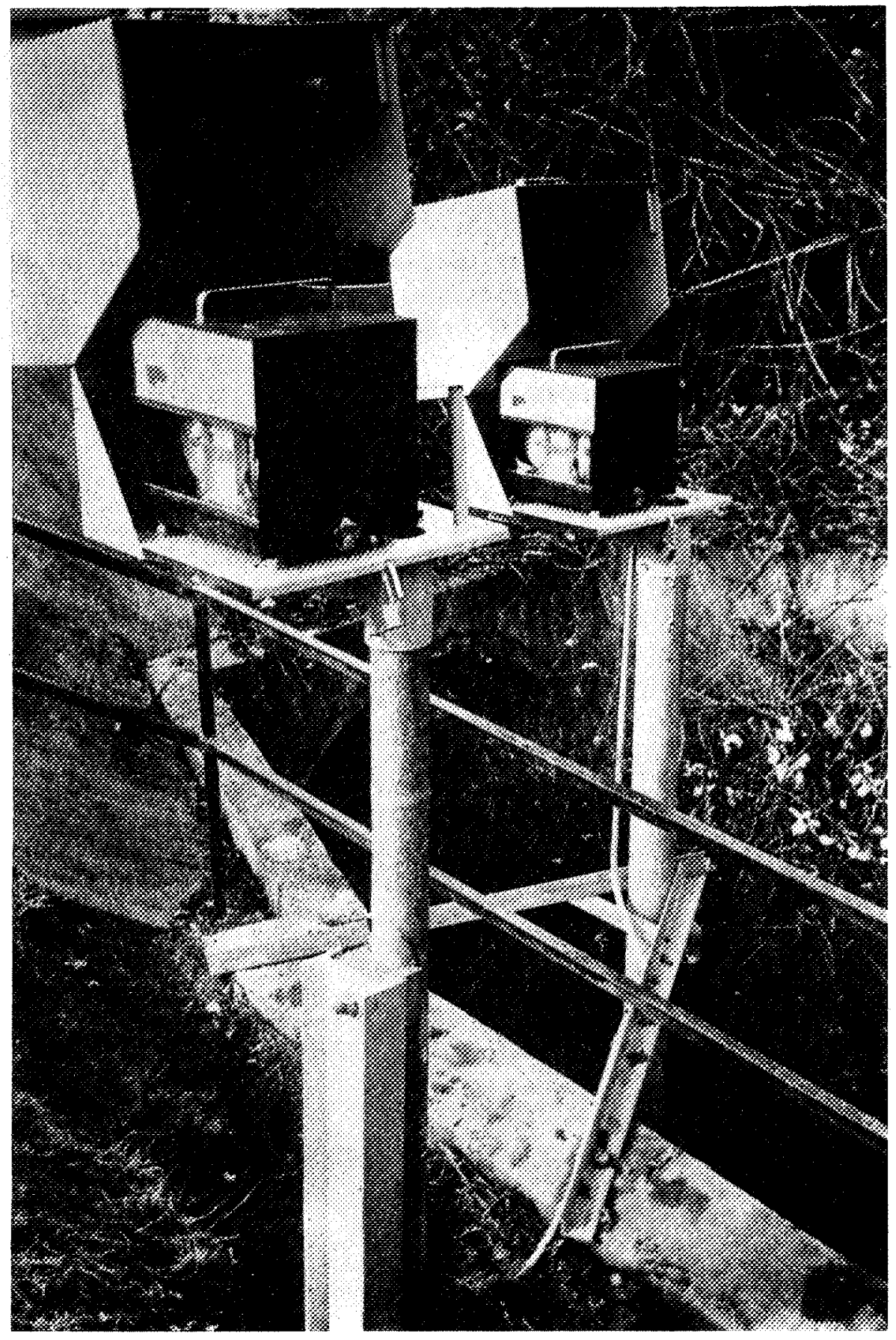

Typical rainfall-runoff gage installation 


\title{
STORM RUNOFF AS RELATED TO URBANIZATION IN THE PORTLAND, OREGON-VANCOUVER, WASHINGTON AREA
}

By Antonius Laenen

\begin{abstract}
A series of equations was developed to provide a better method of determining flood frequencies in the Portland-Vancouver urban area than is now available. The resulting regression equations can be used to compute peak discharge and storm runoff with a standard error of estimate of approximately 30 percent. Basins used to define the regression equations ranged in size from 0.2 to 26 square miles. Those physical basin parameters that proved to be significant are: drainage area, effective impervious area, storage, rainfall intensity, basin slope, and soil infiltration. The equations indicate that total urbanization of an undeveloped basin can increase peak discharge as much as $3 \frac{1}{2}$ times and almost double the volume of storm runoff.

Impervious area, as delineated by mapping techniques, proved to be an inadequate physical parameter for use in the regression equations because builders and planners have devised many methods of routing storm runoff from impervious areas to the main channel (in effect, speeding up or slowing down the response to the storm). In some parts of the study area, storm runoff was diverted into dry wells and never entered the main channel. To define the effect of this rerouting, the digital model was used to find an effective impervious area that would "best fit" the rainfall-runoff data. Field estimates to verify the effectiveness of the impervious area for two of the basins showed that optimizations were within 20 percent of those shown by the digita1 mode1.

Users of these data who may find the effective impervious area a difficult, expensive, and time-consuming parameter to obtain have an alternative. The combination of land-use type I (parks, forests, and vacant lots) and Type II (agriculture) proved to be an excellent inverse indicator of impervious area. Land-use types $I$ and II, coupled with the street-gutter density, an indication of effective routing, provide the user with alternative indices of urbanization.
\end{abstract}


Storage, as defined by the surface area of lakes, ponds, marshes, flood plains, depressions, and detention facilities, proved to be a highly significant parameter in determining peak flow. Sensitivity analysis shows that peak flows may be decreased as much as 40 percent in a basin with 1 percent of its area utilized for storage, whereas peak flows may be decreased as much as 70 percent in a basin with 10 percent of its area in storage. These gross approximations are highly dependent on the location of the storage in the basin.

\section{INTRODUCTION}

The Portland metropolitan area is in a period of rapid growth. This rainfa11-runoff study was done in response to a need by local designers and planners to evaluate the effect of urbanization on runoff and to determine the magnitude and frequency of floods. The project provided an opportunity to obtain rainfal1-runoff information in the urban environment of the Portland metropolitan area. The purpose of this report is to present an interpretation of the data collected and summarize a series of regression equations that define the magnitude and frequency of floods in the Portland urban area.

\section{$\underline{\text { Rainfa11-Runoff Processes }}$}

Rain falling on the land surface fills depressions, infiltrates into the soil, and runs off to drainage channels. Most natural and rural land has some topographic relief and is covered by vegetation. The land is considered to be pervious, or capable of infiltrating some portion of the rainfall. Overland runoff is controlled by the magnitude and intensity of the rainfall event, soil infiltration, vegetation, land slope, topography, drainage geometry, surface geology, and urbanization.

Almost a11 land has some impervious cover which prevents infiltration and is dependent predominantly on soil type, surface geology, and urbanization. Rain falling on the impervious cover runs off almost immediately, and surface depressions fill quickly. If the impervious area is not directly connected to a drainage channel, the adjoining pervious area will attenuate the almost complete and rapid runoff which will both infiltrate partially into nearby soil and lose some of its velocity. However, much of the runoff from the impervious cover eventually appears as flow in the channel.

\section{$\underline{\text { Problem }}$}

Urbanization brings with it impervious cover and modifications to drainage systems that generally result in increased discharge-carrying capacity. The increase in impervious area reduces the area available for infiltration, thus increasing the amount of runoff for any rainfall event. The response of a rainfal1-runoff event is also changed; it is faster and more intense, primarily because of the increased hydraulic efficiency of the overland- and channe1-flow conditions. Urbanization, however, can be a paradox. The paving over of the land, the creation of concrete channels, the stripping of natural vegetation and forest litter, and the compaction of soils should increase runoff in all respects. Runoff volumes almost always increase as a result of 
urbanization. Peak discharges, on the other hand, are affected by man's structures and channel modifications. Peak discharges can and sometimes do decrease because of, or in spite of, urbanization.

In the Portland metropolitan area, the effects of urbanization on flood peaks were not accurately known. This study was made to define magnitude and frequency of floods more accurately for the area, thereby providing more adequate tools for design and planning than are presently available.

\section{Present Solution}

Various methods are presently available to estimate floods in urban areas, and most of these use rainfall-intensity statistics. One of the most common methods for computation is a rational formula $(Q=\mathrm{CiA})$ that involves the selection of three values--the coefficient of runoff (C), indicating a dependency on various watershed characteristics; the rainfa11-intensity duration (i) related to the time of concentration; and the area (A) of the basin. As can be inferred from the explanation of the rainfal1-runoff processes, both the coefficient of runoff and the time of concentration are complex, difficult to express in a single value, and nearly impossible to obtain to any degree of accuracy in the absence of actual data.

\section{Solution Used in This Study}

An analysis was made of rainfa11-runoff data to improve the accuracy of assessing and estimating the effect of urbanization on the magnitude and frequency of floods. Data from 24 streamflow sites and their associated rain gages, operated by the U.S. Geological Survey (USGS) and the city of Portland, were used to calibrate a digital rainfal1-runoff model for each basin. The calibrated digital model was used to generate a synthetic set of flood peaks based on 70 years of storm data from National Weather Service records for Portland. The resulting annual peak-flow and storm-runoff information was used to define individual flood-frequency relations for each gage site. The relations, in turn, were regressed to physical basin parameters resulting in regression equations for peak discharges and volumes for selected exceedance probabilities. In addition, a plot of length-slope ratio to lag time was used to evaluate the effect of urbanization on the lag time of a basin.

\section{Acknowledgments}

This study was done in cooperation with the city of Portland, Clark and Multnomah Counties, and the U.S. Army Corps of Engineers. The author acknow1edges the direct cooperation of the city of Portland Department of Public Works, Bureau of Sanitary Engineering, and especia11y Messrs. Gregory Kurahashi, George Myra, and William Boyd, who gave their time and supplied data to meet the Survey's schedule and criteria. 


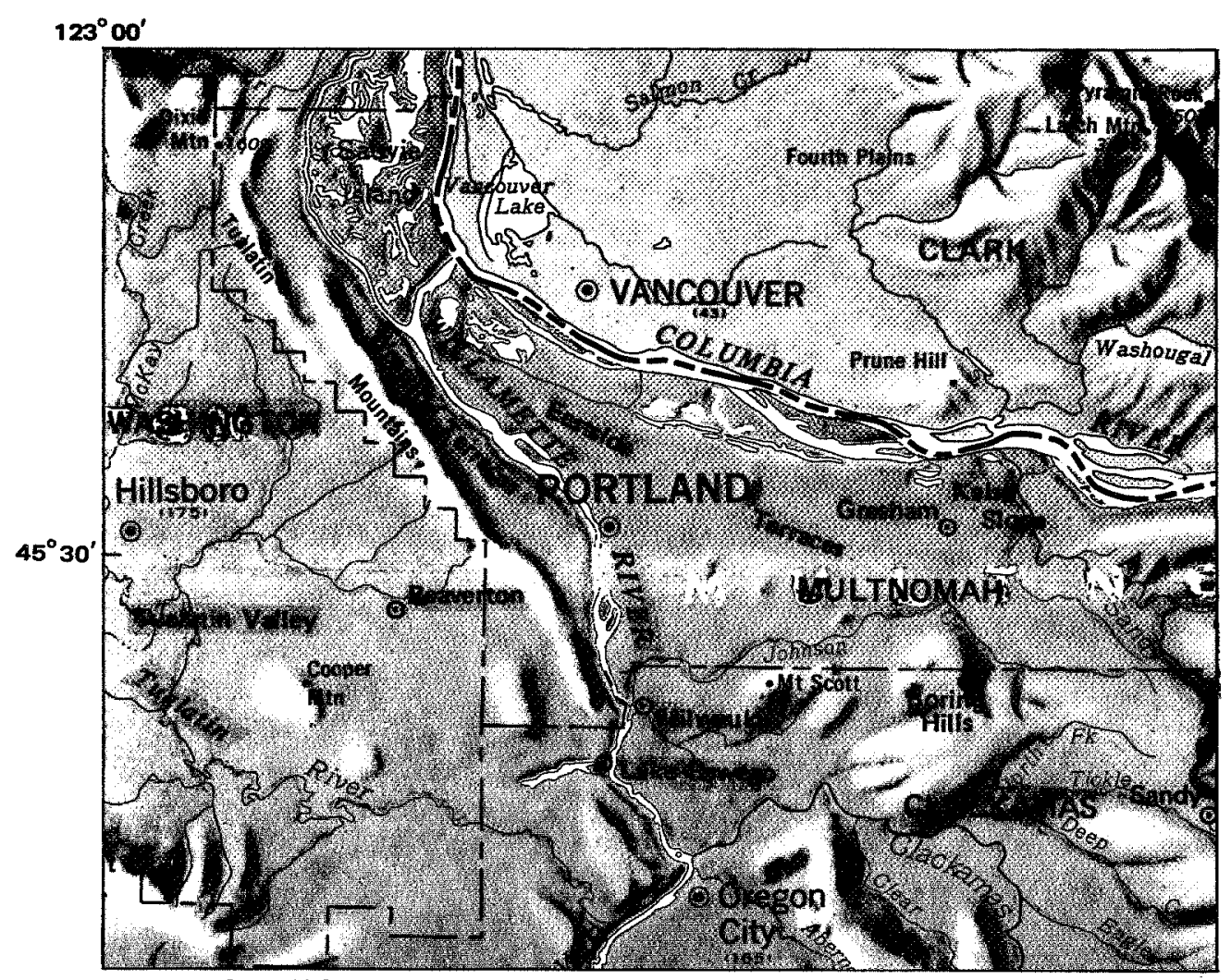

Base map from U.S. Geological Survey Oregon and Washington (relief)

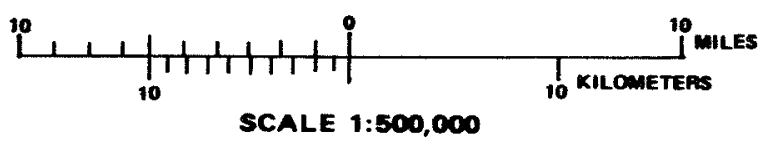

Figure 1.-Geography of the Portland-Vancouver Area.

\section{PHYSICAL SETIING}

\section{Geography}

The Portland-Vancouver metropolitan area lies at the confluence of the Columbia and Willamette Rivers (see fig. 1 and p1. 1). Geographically, the area can be divided into three subareas--east Portland (east of the Willamette River), west Portland (west of the Willamette River), and Vancouver (north of the Columbia River).

\section{East Portland}

The east Portland area is roughly bounded by four large rivers--the Columbia River on the north, the Willamette River on the west, the Clackamas River on the south, and the Sandy River on the east. The area includes the 
following distinct topographic features: the Boring Hi11s, the Kelso slope, the east-side terraces and associated small hills and buttes, and the columbia River flood plain.

The Boring Hills is an area of rolling hills of volcanic and erosional origin. Several of the hills reach an altitude of about $1,000 \mathrm{ft}$. The highest is Mount Scott (alt 1,083 ft), which is about $800 \mathrm{ft}$ higher than the terraces to the west and north. The Boring Hills are divided into three main parts by broad and gently rolling valleys.

The Kelso slope is a dissected northwestward-sloping surface west of the canyon of the Sandy River. It slopes from an altitude of about 1,000 ft near Sandy to about $400 \mathrm{ft}$ east of Gresham. A thick clayey soil underlies most of the Kelso slope and valleys in the Boring Hills. The relatively impermeable soil and the sloping land surface cause a rather rapid runoff of surface water.

The east-side terraces were formed by the ancestral Columbia and Willamette Rivers during a time when the rivers were flowing at higher levels than at present. Three isolated hills--Rocky Butte, Mount Tabor, and Kelly Butte--rise about 200 to $400 \mathrm{ft}$ above the surrounding terraces. These hills are composed of the Pliocene and Pleistocene Boring Lava and associated remnants of the Pliocene Troutdale Formation and stood as "is lands" when the streams were forming the terraces. The terraces do not have a we11-developed stream system in al1 places and are underlain mostly by permeable sand and grave1. Although the precipitation is fairly abundant, most of it percolates down to the ground-water body and leaves the area by underflow.

A major feature of the terraces is a broad abandoned stream channel that extends in a northwestward arc for about $12 \mathrm{mi}$ from the Clackamas River through the Sellwood district to the Hawthorne Bridge. This channel probably once carried the flow of the clackamas River and perhaps, at times, a11 or part of the flow of the Willamette River. This feature is now drained in part by Crystal Springs, Kellogg, lower Johnson, and Mount Scott Creeks.

The flood plain south of the Columbia River contains several marshes, shallow lakes, and sloughs. Most of the flood plain is protected by artificial dikes and is only partly flooded during years of exceptionally heavy rainfall or of very high water in the Columbia River. Under natural conditions, however, the flood plain is partly or completely flooded during normal high-water periods and is naturally drained through a system of sloughs and minor streams.

\section{West Portland}

The west Portland area can be roughly divided into the following areas: the Tualatin Mountains (West Hills), the west-side terraces (downtown Portland), and the lower Tualatin Valley (see fig. 1). 
The northwest-trending Tualatin Mountains rise to an altitude of $1,100 \mathrm{ft}$ in this area and extend as far south as Lake Oswego. These mountains are better known locally as the West Hills. The flanks sloping northeastward to the flood plains of the Columbia and Willamette Rivers and southwestward into the Tualatin Valley are deeply dissected by streams. The mountains are underlain by the Miocene Columbia River Basalt Group, which is overlain by upland silt.

The eastern and southeastern parts of the Tualatin Valley are separated from the floor of the Willamette Valley by low ridges and uplands called the West Linn Heights, an extension of the Tualatin Mountains. Oregon City, across the Willamette River, lies on a bluff which is a continuation of the heights.

According to Brown (1963), the downtown Portland area from about 50-foot altitude to the base of the West Hills consists of older alluvium and terrace grave1. The terrace gravel was deposited by the ancestral Willamette and Columbia Rivers. Below the 50-foot altitude, the Willamette River flood plain consists of soils that are finer and less permeable than the terrace gravel.

The Tualatin Valley is a broad elliptical plain surrounded by long terraces that slope toward the center of the valley. Cooper and Bull Mountains are near the middle of relatively flat lowlands. The valley floor consists primarily of silt underlain by a thick layer of impermeable clay and silt with widely separated beds of sand and gravel. The clay is so tight in some areas that it takes several months of winter rains before the soil is wetted several feet below the surface.

\section{Vancouver}

According to Mundorff (1964), the Vancouver area consists of a series of nearly flat plains and benches rising steplike from the level of the Columbia River. The terraces here, as in the Portland area, are underlain mostly by permeable sand and gravel, and rain percolates readily into the soil. The area from an altitude of $50 \mathrm{ft}$ to the foothills is locally known as Fourth plains. It contains both the remnants of the original alluvial fill from the East Fork of the Lewis River and the more recent alluvial and glacial outwash material deposited by the Columbia River. The lowest bench, at an altitude below $50 \mathrm{ft}$, is the flood plain of the Columbia. Vancouver Lake, an old river meander, is part of this flood plain.

\section{Drainage Systems}

The entire study area is approximately $500 \mathrm{mi}^{2}$ and lies within the Columbia River drainage basin, which has a drainage area of $241,000 \mathrm{mi}^{2}$. Other major streams that drain parts of the study area include the Willamette River, with a drainage area of $11,100 \mathrm{mi}^{2}$; the Tualatin River, with a drainage area of about $700 \mathrm{mi}^{2}$; the Clackamas River, with a drainage area of about $900 \mathrm{mi}^{2}$; and the Sandy River, with a drainage area of approximately $500 \mathrm{mi}^{2}$. 
In east Portland, the largest of the sma11 streams that drain the area are Johnson, Crystal Springs, Mount Scott, and Kellogg Creeks, draining into the Willamette River; Rock and Deep Creeks, draining into the Clackamas River; and Beaver and Kelly Creeks, draining into the Sandy River. The east-side terrace area has few streams and many undrained depressions. The only streams originating in the terrace area are Crystal Springs Creek, Kellogg Creek, and some minor tributaries in the Oak Grove area.

In the west Portland area, the largest streams are Rock Creek and its tributaries (Beaverton and Cedar Mill Creeks) and Fanno Creek. These streams drain into the Tualatin River. Numerous canyons drain the east slope of the West Hills into the Willamette River.

In the Vancouver area, the largest creeks include Burnt Bridge Creek, which drains into Vancouver Lake, and Cougar and Salmon Creeks, which drain into the Columbia River. Here, as in the east-side terrace area, elongated depressions trap rainwater.

\section{RAINFALL CHARACTERISTICS}

Portland has a winter-rainfall climate, with a normal annual precipitation of 37.6 in. $1 /$ recorded at the Portland International Airport. Approximately 88 percent of the total annual precipitation occurs from October through May as the result of frontal storm systems spawned in the Pacific Ocean. Heavy downpours are infrequent, but gentle rains occur almost continually during the winter. The remaining 12 percent of the annual rainfall occurs from June through September, generally from convection storms occurring on the average of once a month. These storms are generally not very intense compared to storms in other parts of the United States, but are more intense for shorter durations than are the winter storms. Snow seldom falls, and generally lasts for only a few days.

Annual precipitation ranges from 38 to $66 \mathrm{in}$, over the project area. At the two long-term, first-order precipitation gages (see fig. 2) at the U.S. Customs House (1872-1973) and the Portland International Airport (1946-79), the annual average precipitation is 38 and 45 in., respectively, for the 1946-73 period. The isopluvial map (fig. 2) shows a 1.8- to 3.0-inch difference in rainfall over the project area for the 6-hour precipitation with 0.02 exceedance probability. The pattern of areal distribution of rainfall intensity is similar to that of annual precipitation. Data for both daily rainfall and unit rainfal1 (5-minute duration) have been adjusted for individual watershed models to compensate for this areal distribution (see table 3 ).

1/ The 1941-70 normal rainfa11 is determined from records collected primarily at the Portland International Airport and from other nearby locations (from Annual Summary published by the National Oceanic and Atmospheric Administration). 


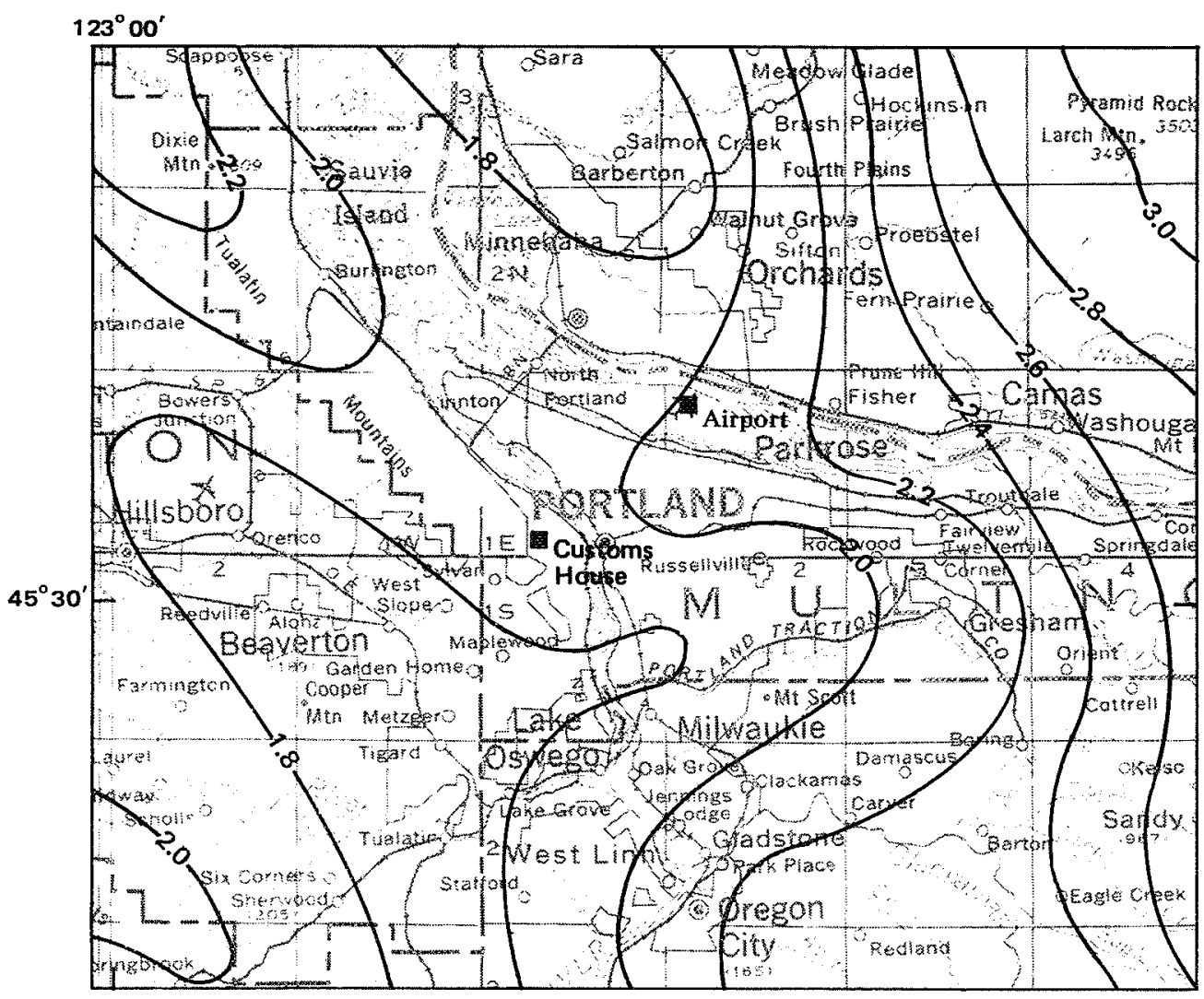

Base map from U.S. Geological Survey Oregon and Washington (State)

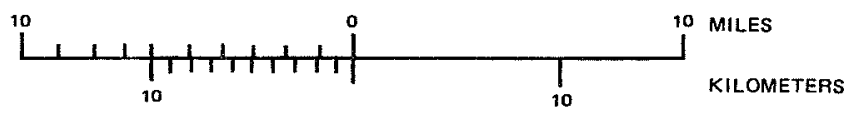

SCALE 1:500.000

National Weather Service official rainfall record station

Figure 2.-Map of 0.02 exceedance probability, (50-year), 6-hour precipitation, in inches, for the Portland-Vancouver area. (Adapted from National Oceanic and Atmospheric Administration, 1973a and 1973b).

Data used for all storm analyses in this report were collected between 1902 and 1973 at the U.S. Customs House between NW. Everett and Davis Streets at Park Avenue. On December 12-13, 1882, and on January 5-6, 1883, daily totals of $7.66 \mathrm{in}$, and $5.55 \mathrm{in.}$, respectively, were recorded. Both these events exceeded the 24-hour, 0.01 exceedance probability intensity (fig. 3 ) for the rainfal1-intensity curves developed from station data for the period 1903-49 (U.S. Weather Bureau, 1955).

During the data-collection period, extremes of note occurred on (1) December 11-12, 1977, when a storm with a 24 -hour extreme of 3.3 in. occurred (which was the maximum-yield storm event for many of the basins); and (2) May 1, 1976, when a hailstorm in Vancouver with 5-, 15-, and 30-minute 


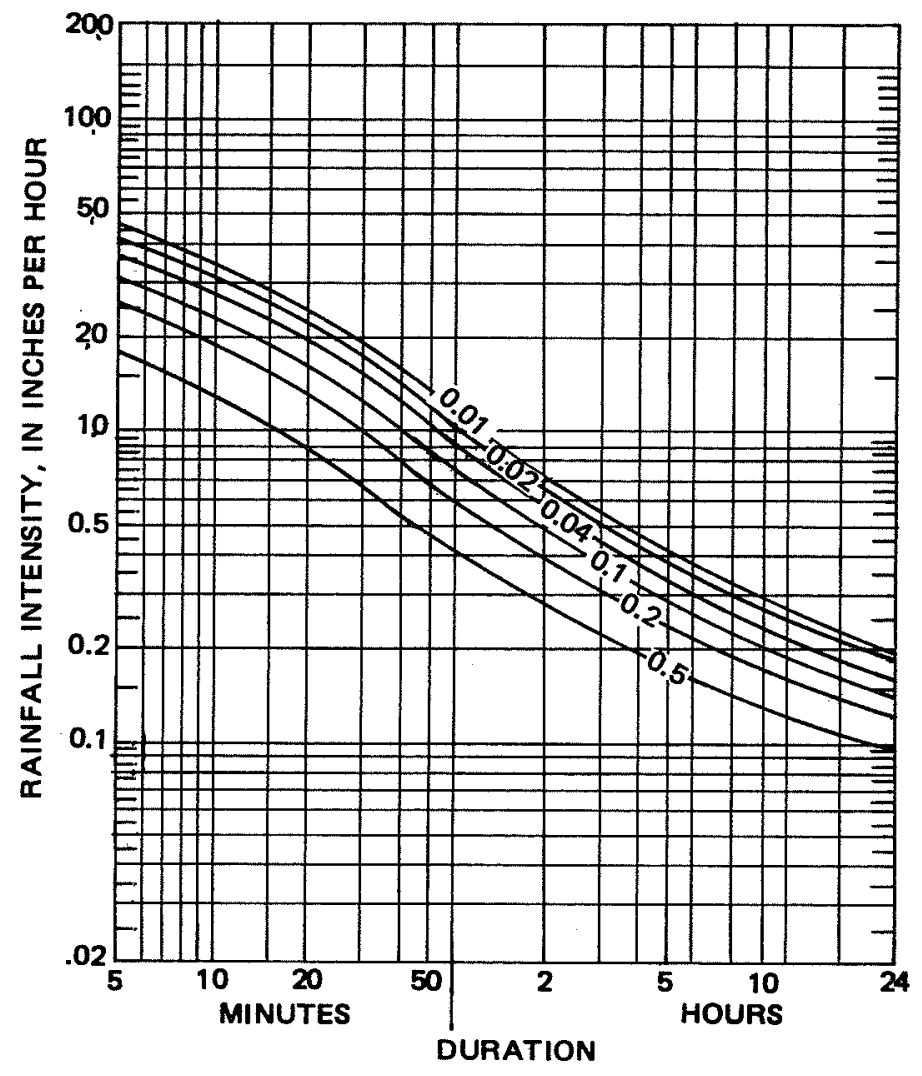

Figure 3.-Rainfall-intensity curves for given exceedance probabilities for U.S. Customs House, Portland, Oreg. (1903-44). (Adapted from intensity curves in U.S. Weather Bureau Technical Paper 25, 1955).

rainfa 11 amounts of $0.34,0.54$, and 0.63 in. $2 /$, respective1y, occurred. The intensity curves (fig. 3) show the December 1977 storm to be about a 0.2 exceedance-probability storm. Rainfall intensity has been greater than 2.5 in. in 24 hours only 25 times during the period 1872-1973. Because of the magnitude of the December 1977 storm, it provided more credibility to the rainfa11-runoff calibrations described in this report. The May 1, 1976, storm in Vancouver plots near the 0.01 exceedance probability for the 5-minute time durations.

The rainfall record used in synthesis for this report does not include the historical extremes mentioned. However, a sufficient length of historical record indicates that any bias due to this exclusion should be slight. This report includes a brief assessment of hypothetical peaks caused by the historic extreme events in comparison with other peaks of record.

2/ For this storm, accumulations of 1 to 2 in. of hail were reported in the vicinity of the Vancouver rain gage. Most of the hail was not measured. The intensities shown reflect very little of the water content associated with the hail. 


\section{Rainfal1-Runoff Data Collection Network}

Rainfal1 and runoff data were collected at 17 streamflow and 18 rain-gage sites maintained by the USGS and at seven sewer-gage and six rain-gage sites maintained by the city of Portland (see p1. 1 for locations of gage sites). (The city sewer-gage and rain-gage network is considerably larger than shown; however, not all sites could be used in this rainfall-runoff analysis.) A description of the instrumentation and methods used for data collection and the bulk of the data collected are included in a report by Laenen and Solin (1978). The remainder of the data is summarized in tables 13 and 14 of this report (raw data were collected at 5-minute intervals).

Data were collected to encompass as much of the urban spectrum as possible, within the limits of certain physical constraints. In the planning phase of the project, hydraulically acceptable sites (those sites where little time would have to be spent defining a stage-discharge relation) were canvassed first. Two sets of scatter diagrams were then developed--drainage area versus impervious area (fig. 4) and drainage area versus basin slope (fig. 5), thereby creating envelopes of experience for the study area. The next step was to define a network with an even scatter of physical characteristics within the envelopes. Voids were filled, where possible, by relaxing origina1site acceptability specifications and using less favorable locations for the network. Figures 4 and 5 show the characteristics for the final network plotted with the original relations. In final analysis, both basin slope and impervious area proved to be significant characteristics and remained in the resulting regression equations.

Discharge measurements were made at al1 sites (including city gages) to verify the stage-discharge relations.

\section{Basin Characteristics}

Table 1 is a compilation of drainage-basin characteristics. Many characteristics were evaluated in the regression-analysis phase of this study and are included in this report. Not all characteristics proved to be significant; however, because they may be valuable for some future statistical analysis, they are presented in this report in their entirety. Table 1 supersedes the basin-characteristics table in the report by Laenen and Solin (1978, p. 4) and includes city of Portland sewered basins. Definitions are as follows (acronyms are shown in parentheses):

Drainage area (DA).--Area of the basin, in square miles, planimetered from USGS $7 \frac{1}{2}$-minute topographic series maps. Basin boundaries were delineated by outlining drainage divides and then adjusting the natural drainage areas, where necessary, on the basis of current storm-sewer information obtained from city and county agencies. A field determination was made at boundaries where drainage area divides could not be determined from the maps. 


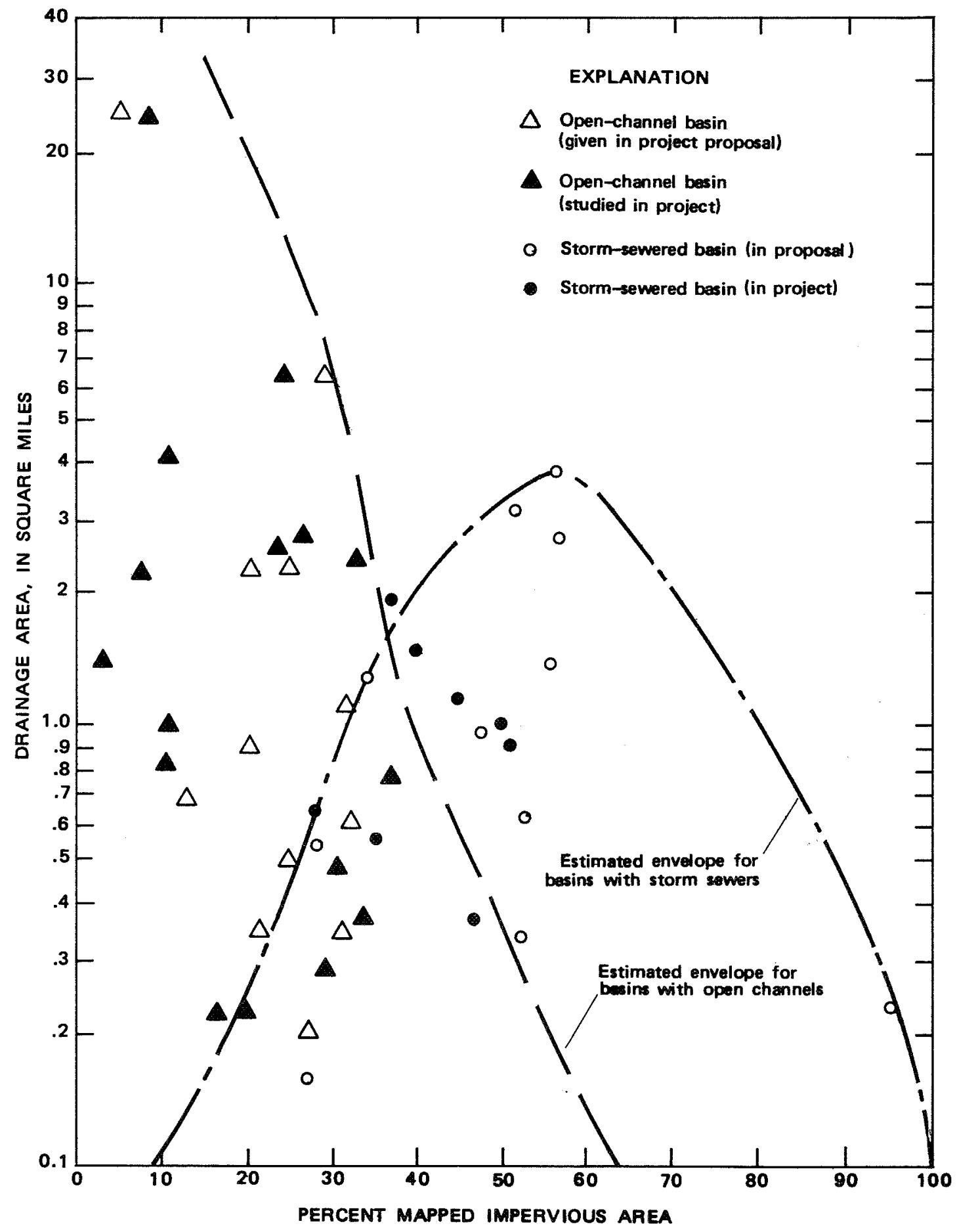

Figure 4.-Distribution of drainage area in relation to impervious area for project data-collection network. 


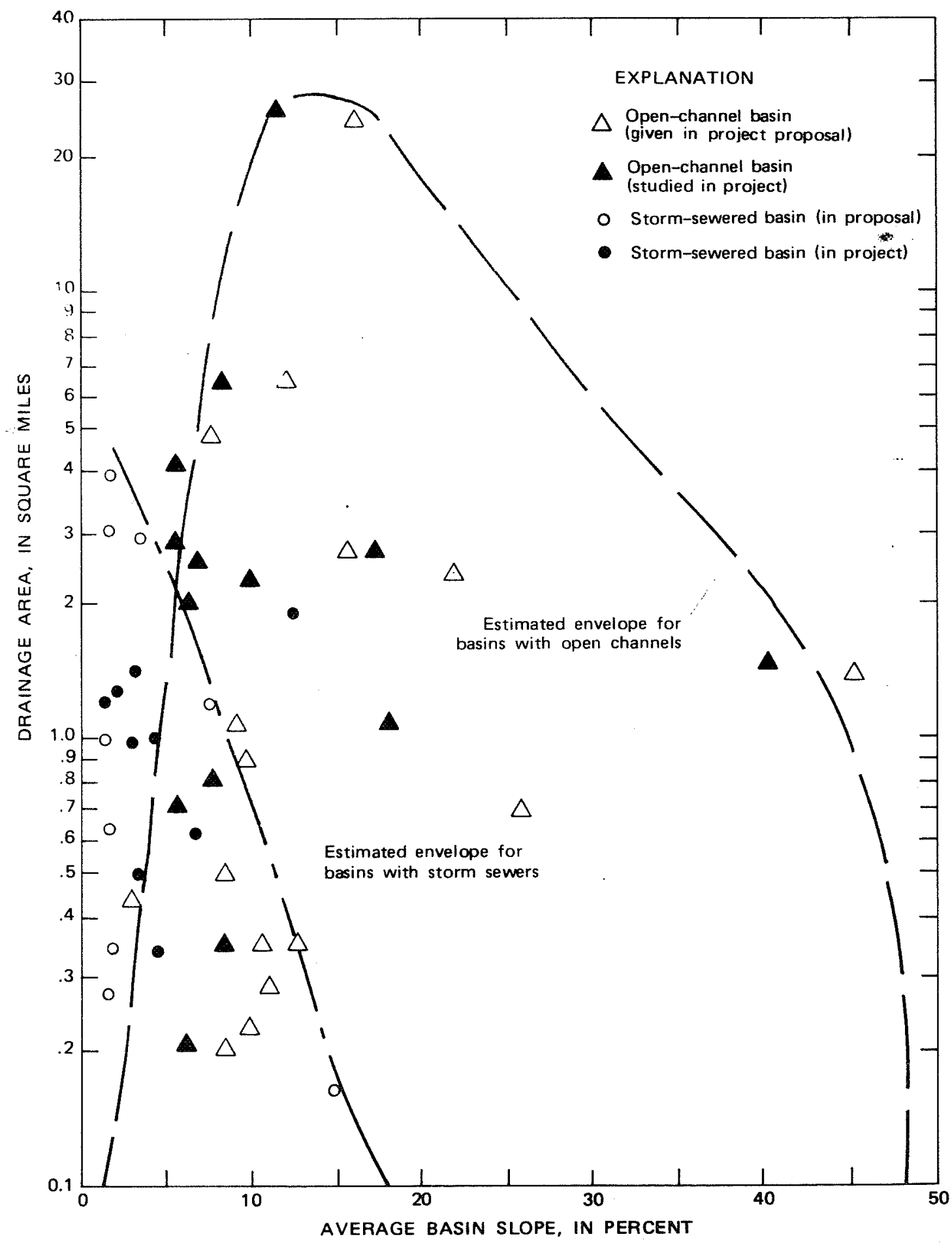

Figure 5.-Distribution of drainage area in relation to average basin slope for project data-collection network. 


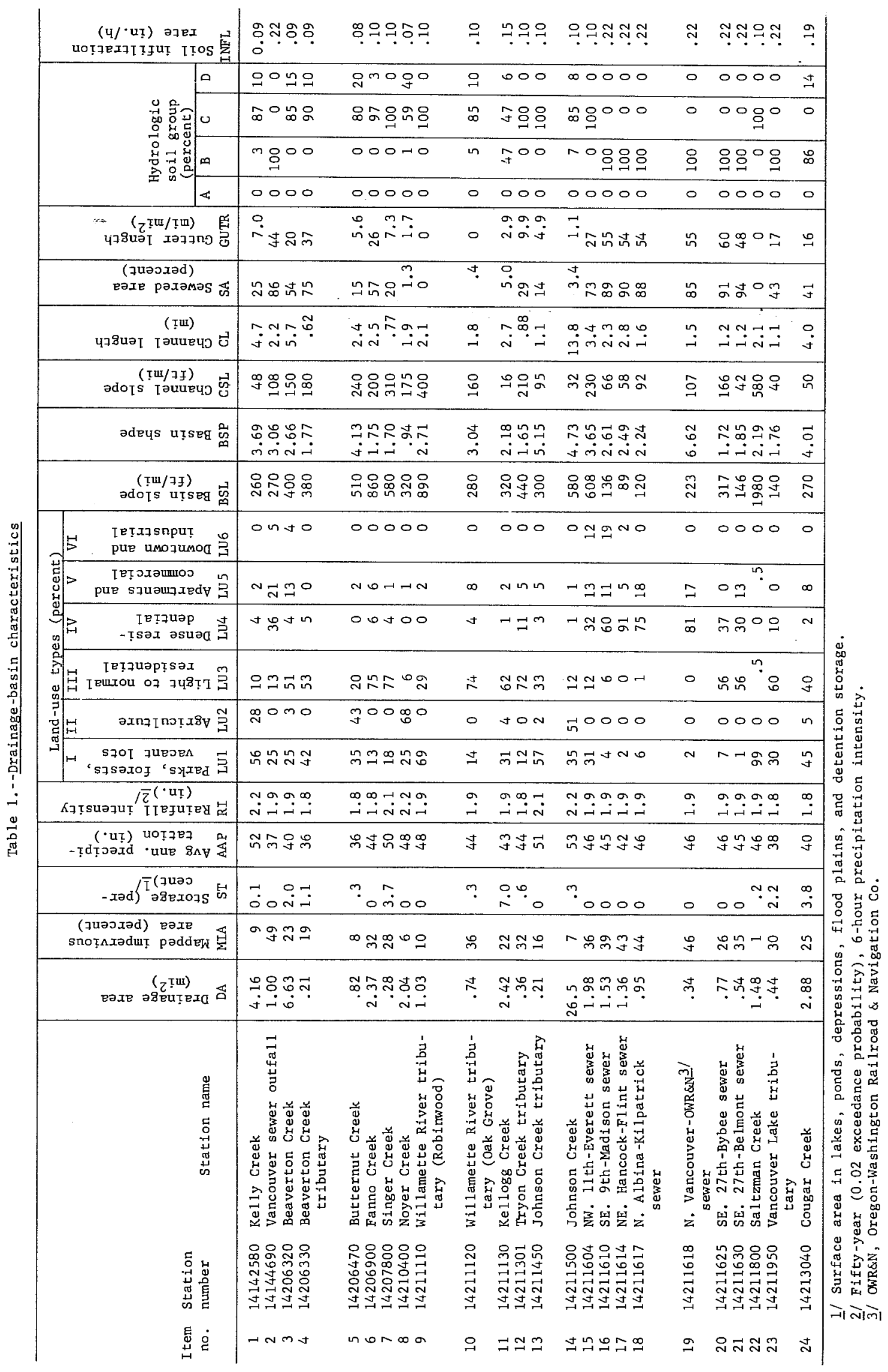


Mapped impervious area (MIA).--Drainage area, in percent of total drainage area, impervious to the infiltration of rain, including such areas as. paved roads, paved parking lots, roofs, driveways, and sidewalks. Impervious area was determined from maps made by both the Metropolitan Service District

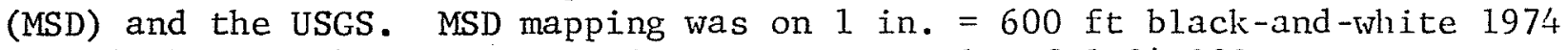
aerial photography. USGS mapping was at a scale of $1: 24,000$.

Storage (ST).--The surface area, in percent of the total drainage basin, where water can be stored during a storm event. This consists of lakes; ponds, marshes, flood plains, depressions, and detention-storage facilities. Add 0.1 percent to this value to make it valid in regression equations.

Average annual precipitation (AAP).--The average annual precipitation, in inches, for the drainage area for the period 1941-70, estimated from National Oceanic and Atmospheric Administration isohyetal maps (scale 1:2,000,000).

Rainfal1 intensity (RI).--The 50-year, 6-hour precipitation, in inches, for the drainage area, determined from isopluvial maps (scale 1:2,000,000) published by the National Oceanic and Atmospheric Administration (1973). In this report, it is commonly referred to as intensity. Subtract $1.7 \mathrm{in}$. from this value to make it valid in the regression equations.

Land-use types.--Land uses in types I through VI, as mapped by MSD and the USGS, and as defined as follows:

I (LU1). Parks, forests, and vacant lots.

II (LU2). Agriculture.

III (LU3). Light-to-norma1 residentia1.

IV (LU4). Dense residential.

V (LU5). Apartments, commercial areas with some lawns, and industrial areas with gravel lots.

VI (LU6). Downtown business, shopping centers, and industrial areas with paved lots.

Note: LU12 is the sum of land-use types I and II.

Land Use Inventory maps at a 1 -in. $=200$-ft scale, which show similar land-use types but in greater detail, are currently in use by MSD.

Basin slope (BSL).--The average slope for the basin, in feet per mile, computed from USGS topographic maps, using the formula described by Wisler and Brater (1959):

$$
\mathrm{BSL}=\mathrm{CL} / \mathrm{DA}
$$

where

$$
\begin{aligned}
\mathrm{C} & =\text { contour interval, in feet } \\
\mathrm{L} & =\text { total length of contours, in miles, and } \\
\mathrm{DA} & =\text { drainage area, in square miles. }
\end{aligned}
$$


The relation of basin slope to main channel slope differs considerably between basins in the project area, probably reflecting basin-terrain characteristics. For instance, the Willamette River tributary at Oak Grove has a channel that closely follows the general level of the basin terrain; therefore, the basin slope is not much greater than the main channel slope. The two slope characteristics for Saltzman Creek also are comparable, because both the basin terrain and the channel are quite steep. Characteristics are quite different, however; for Kellogg Creek where the stream lies in a lowgradient valley with steep side slopes. Johnson Creek has similar characteristics and thus has a considerably greater basin slope than channel slope.

Basin shape (BSP),--The ratio of the length to average basin width calculated by the formula:

$$
\mathrm{BSP}=\mathrm{Lc} \mathrm{c}^{2} / \mathrm{DA}
$$

where

Lc = straight-line distance from basin outlet to the point on the basin divide used to measure the main channe1, and

$\mathrm{DA}=$ drainage area.

Channel slope (CSL).--The channel slope, in feet per mile, for the basin as determined from topographic maps. It is defined as the difference in elevation, in feet, at points 10 percent and 85 percent of the distance upstream from the gaged site along the main channel (see channel length) divided by the distance, in miles, along the channel between the two points.

Channel length (CL).--The channel length, in miles, for the basin as determined from USGS maps. It is defined as the distance from the gaged site upstream to the watershed divide along the most we11-defined and longest channel.

Sewered area (SA).--Area, in percent of total drainage area, serviced by storm sewers as taken from drainage maps supplied by various city and county agencies. To define the boundary of the sewered area, the distance of one city block was added to the outermost catch basins on the assumption that the outer catch basins, on the average, would drain approximately a one-block area. Add 0.1 percent to this value to make it valid in regression equations.

Gutters (GUTR).--Length of street gutters, in miles per square mile, defined by drainage maps showing curbs and catch basins, and by field delineation. Add $0.1 \mathrm{mile}$ to this value to make it valid in regression equations. Multiply by 2 if both sides of the street have gutters.

Hydrologic soil group.--Soil group types A through D, as mapped by the U.S. Soil Conservation Service in their county soil surveys (1975) and unpublished soil maps. The range of infiltration rates, in inches per hour, is bracketed following each definition: 
A. (Low runoff potential). Soils having a high infiltration rate, even when thoroughly wetted, and consisting chiefly of deep, we11-drained to excessively drained sand or gravel [0.45 - 0.30].

B. Soils having a moderate infiltration rate when thoroughly wetted and consisting chiefly of moderately deep to deep, moderately well to well-drained soils with moderately fine to moderately coarse texture $[0.30-0.15]$.

C. Soils having a slow infiltration rate when thoroughly wetted and consisting chiefly of soils with a layer that impedes downward movement of water, or soils with moderately fine to fine texture $[0.15-0.05]$.

D. (High runoff potential). Soils having a very slow infiltration rate when thoroughly wetted and consisting chiefly of clay soils with a high swelling potential, soils with a permanent high water table, soils with a claypan or clay layer at or near the surface, and shallow soils over nearly impervious material [<0.05].

Soil infiltration rate (INFL).--Average soil infiltration, in inches per hour, as determined by averaging ranges given for each soil group, types $A-D$, then weighting them by percent of total basin covered.

\section{DESCRIPTION OF THE HYDROLOGIC ANALYSES USED}

\section{Digital Mode1 Calibration}

The USGS rural and urban rainfa11-runoff models developed by Dawdy, Lichty, and Bergmann (1972) were used for modeling and simulation. The intent of this report is not to fully describe the models used, but to describe them adequately enough to give some insight into the models and regression results presented.

Data collected were entered into USGS models as daily rainfa11 and evaporation (to define antecedent moisture conditions) and as unit rainfall (the individual storm events). During the model-calibration phase for each basin, the various parameters were optimized to yield the best statistical results. Following is a brief description of the model. (See table 2 for a list of mode1 acronyms and definitions.)

Saturated and unsaturated soil-moisture levels for the pervious area are accounted for by using the parameters EVC, RR, BMSM, and DRN. The mode1 simulates hydrographs for pervious and impervious basin segments and adds them together. The model is divided into three phases of optimization--runoff volume, timing, and peak. In both the volume and peak phases, soil-moisture accounting parameters (EVC, RR, BMSM, DRN) and soil-infiltration parameters (PSP, KSAT, RGF) are optimized. For the pervious area, the computation of rainfa11 excess is accomplished using a modified infiltration equation developed by Phillip (1954). In the timing phase, routing parameters (TC, KSW) are optimized. The surface-routing component is based on unit hydrograph concepts (Sherman, 1932) and assumes a model composed of linear 
Table 2.--Identification and definition of parameters used in the digital model 17

\begin{tabular}{|c|c|c|c|}
\hline Component & $\begin{array}{r}\text { Parameter } \\
\text { identifier }\end{array}$ & Units & Definition \\
\hline \multirow{4}{*}{$\begin{array}{l}\text { Antecedent- } \\
\text { moisture. } \\
\text { accounting }\end{array}$} & EVC & -- & $\begin{array}{l}\text { Pan coefficient that converts pan evapo- } \\
\text { ration to potential evapotranspiration }\end{array}$ \\
\hline & $\mathbf{R R}$ & -- & $\begin{array}{l}\text { Coefficient that proportions daily rain- } \\
\text { fall into infiltration and surface } \\
\text { runoff. }\end{array}$ \\
\hline & BMSM & Inches & $\begin{array}{l}\text { Maximum effective soil-moisture storage } \\
\text { volume at field capacity. }\end{array}$ \\
\hline & DRN & $\begin{array}{l}\text { Inches } \\
\text { per hour }\end{array}$ & $\begin{array}{l}\text { Constant coefficient that controls } \\
\text { drainage rate of infiltrated soil } \\
\text { moisture. }\end{array}$ \\
\hline
\end{tabular}

PSP Inches Capillary potential, or soil suction, at wetted front for field-capacity conditions.
Infiltration RGF -- Ratio that varies PSP over the soil- moisture range from wilting point to field capacity.
KSAT Inches Minimum saturated value of hydraulic con- per hour ductivity to determine infiltration rates.

\begin{tabular}{llc}
\hline TC & Minutes & $\begin{array}{c}\text { Time characteristic for translation of } \\
\text { rainfall excess by distance-area } \\
\text { histograms. }\end{array}$ \\
Routing & $\mathrm{KSW} \quad$ Hours $\quad \begin{array}{c}\text { Time characteristic for 1inear reservoir } \\
\text { routing. }\end{array}$ \\
\hline
\end{tabular}

1/ Taken from Dempster (1974). 
reservoirs and channels. Optimization is obtained by "hill-climbing" techniques, using bounded parameters (as described by Dawdy, Lichty, and Bergmann, 1972) and the objective function (sum of the squared deviations of logarithms) as the statistical indicator of "best fit."

The model was used to optimize four soil parameters (PSP, KSAT, RGF, and BMSM). All other parameters were set to values computed from either regional data or graphical analysis (table 3 ).

The urban model allows for the input of multiple rain-gage data for soilmoisture accounting. Subbasin boundaries are defined based on rain-gage location. Sets of distance-area values for both pervious and impervious areas were required for each subbasin. The combination of distributed moisture accounting (multiple input) and distributed routing made it possible to simulate the effects of both rainfall variability and urban development.

The model was used to evaluate the effective impervious area (EIA). This evaluation was based on the premise that runoff volume of a storm in urban areas is highly dependent on the impervious area. This premise has been found to be valid in most urban studies. Verification of this method of estimating effective impervious area was accomplished by a field survey of the effective impervious area in two of the smaller basins.

In many areas in and around Portland and Vancouver, runoff from roofs and any impervious surface either partially or totally drains into dry wells, discharges directly onto lawns, or is routed by unimproved minor channels. In some basins, entire sewered areas are dry-welled. The impervious areas contributing runoff to dry wells or pervious areas in a drainage basin are difficult to determine. One way of estimating an effective impervious area was by using the optimal fitting technique with the Geological Survey's digital rainfal1-runoff calibration model. Although this technique lumps many soil and topographic characteristics together, including the impervious area, it still yields a reasonable estimate of the effectiveness of the hydraulic linkage in the system. Effective impervious area can be considerably different from that which may be mapped. To define impervious areas in ungaged basins, the hydraulic connections between the impervious areas and the stream would have to be cataloged, and then evaluated for their effectiveness. This is time consuming and may be impractical for most studies.

The first phase of the model (volume fitting) was used to compute the standard error for several different values of impervious area. Figure 6 shows how the model "fit" varied with the change in impervious area for two basins. It shows the plot of impervious area, in percent, versus the resulting standard error, with the low point (the best standard error) on the resultant curve yielding the optimal impervious area. The computer-modeled optimal impervious area is, for al1 practical purposes, the effective impervious area. 


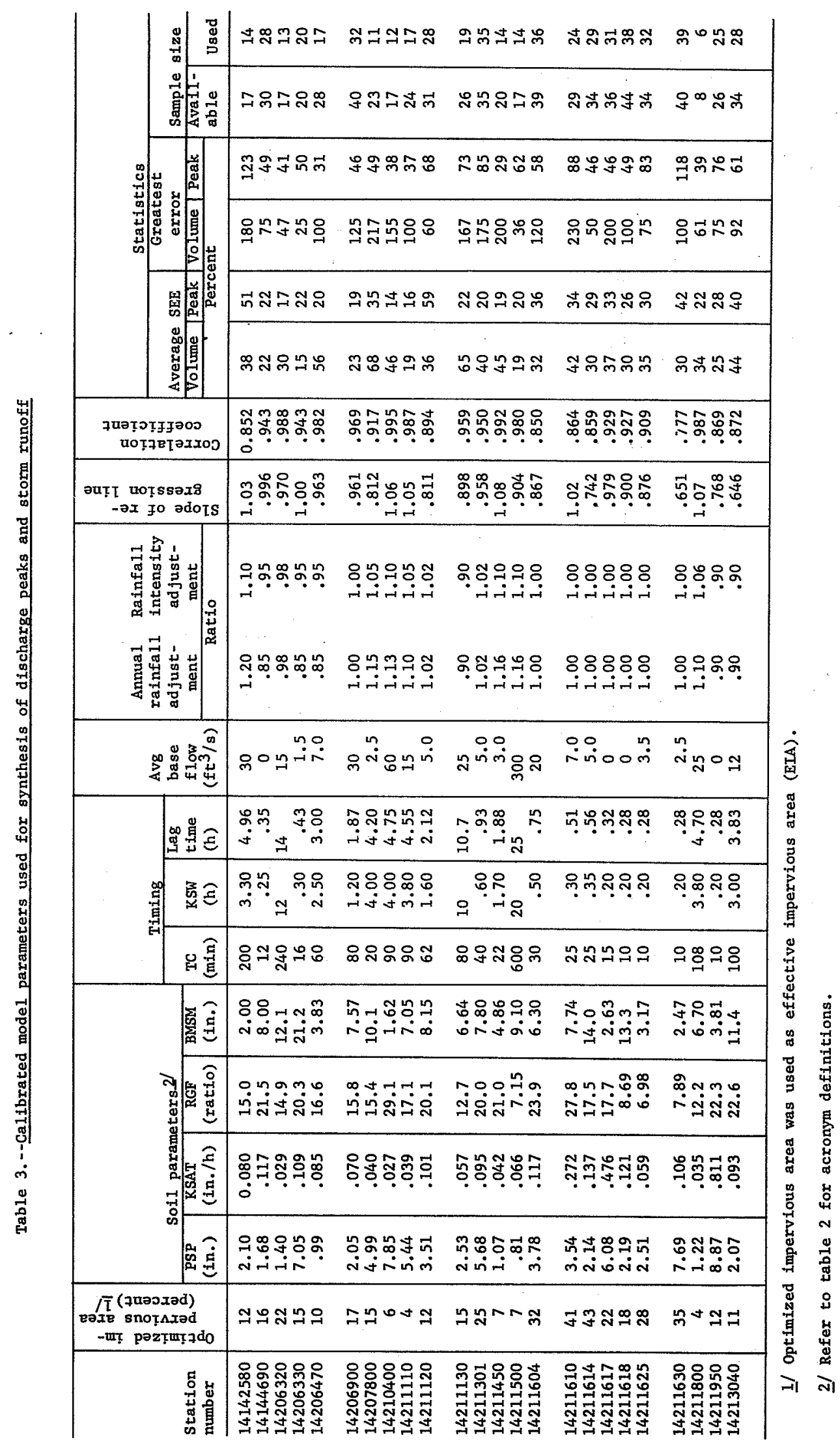



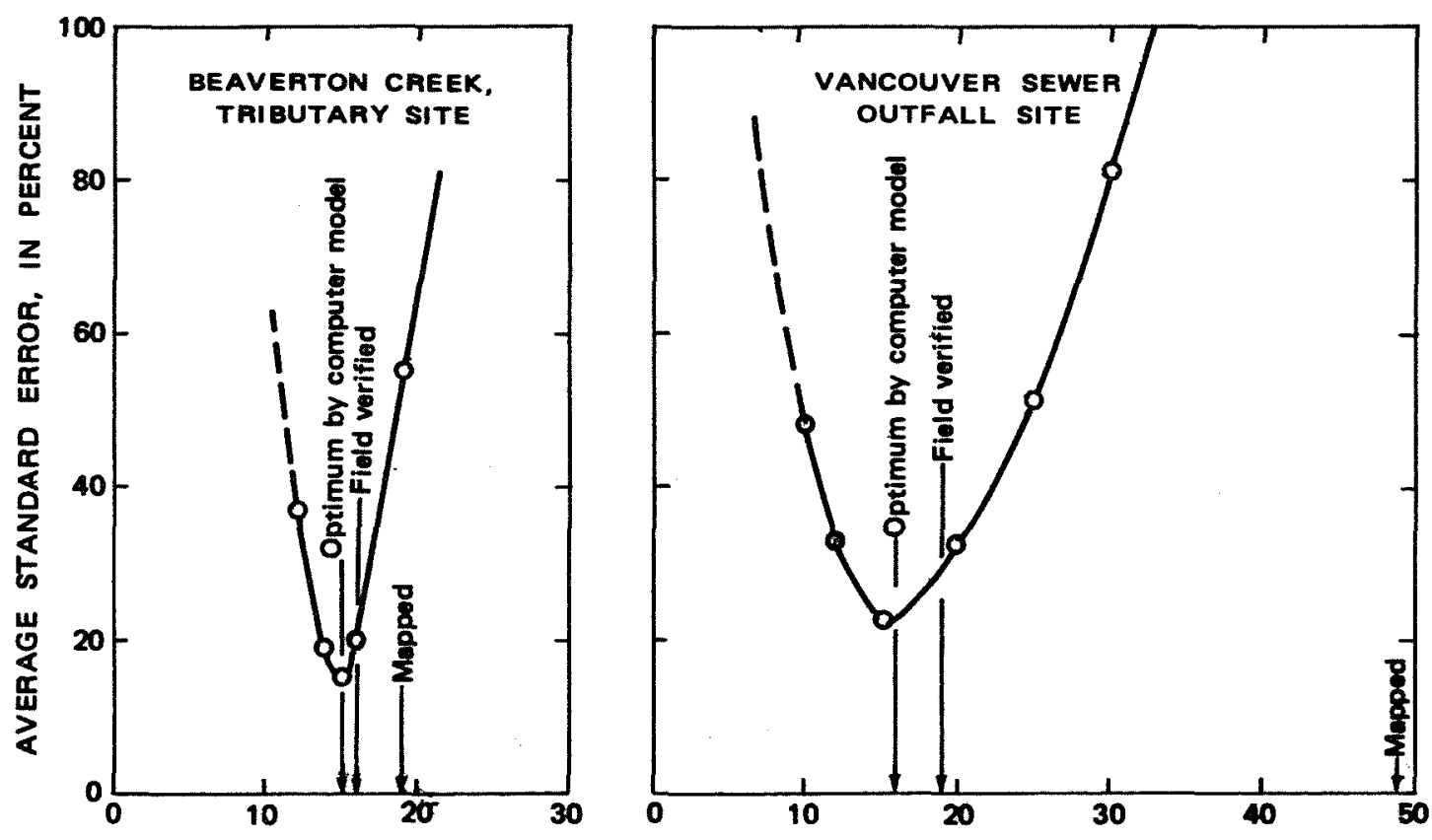

IMPERVIOUS AREA, IN PERCENT

Note: Curve delineated by model results of average standard error for various imposed impervious areas with all other model parameters held constant.

Figure 6.-Determination of effective impervious area by digital model.

Field verification was undertaken in two basins--Beaverton Creek tributary (14206330) and Vancouver sewer outfall (14144690). Figure 6 shows the plot of impervious area versus SEE for Beaverton Creek tributary, with the field estimate of the percentage of effective impervious area and the mapped percentage of impervious area indicated. The field estimate showed almost all impervious areas to be effective except for some parking lots that allowed runoff to spill over onto adjacent fields. The Vancouver sewer-outfall basin (see fig. 6) showed the largest difference between mapped impervious area and the computer optimum or effective impervious area for all the basins studied. A field survey showed that only the streets, the freeway, and some downtown buildings were directly connected to the storm-sewer system. In some parts of the basin, paved areas drained into unimproved ditches and swales. In most of the basin, residential dwellings and some downtown buildings had roof drains that were connected directly to dry wells. This basin and adjacent basins have the most extensive use of dry wells as a building practice in the entire study area. There was no way to define the effectiveness of these dry wells during any one storm. For field estimation purposes, all roofs and paved areas were subtracted from the total impervious area where overflow drained onto lawns. No attempt was made to modify the size of the drainage area, which, in reality, has a reduced area contributing to runoff. 
The optimization used to define an effective impervious area as described above provides insight into processes that occur between runoff from the actual impervious areas and the ultimate flow in the main channel. This optimization provides a crude way to define interactions that are too complicated to define for a large basin. To some degree, it modifies the apparent influence of soil and topographic parameters of the basin. This optimization technique also masks any error in total drainage area and could reflect some slight bias in the final regression results.

Figures 7, 8, and 9 are graphs of Fanno Creek data. Similar data are available for other basins. Figure 7 is a plot of simulated versus observed runoff volumes, figure 8 is a plot of simulated versus observed peak flows, and figure 9 is a typical storm hydrograph. Table 3 shows a summary of the model calibration results. The average SEE was 36 percent for volumes and 28 percent for peaks. Generally, the model did not simulate thunderstorms well because of the nonuniform areal distribution of the rain. For drainages more than approximately $1 \mathrm{mi}^{2}$, only winter storms were modeled because summer thunderstorms generally simulated lower discharges than observed. In these drainage areas, winter storms produced much larger peaks than did thunderstorms. For basins less than approximately $1 \mathrm{mi}^{2}$, al1 storms were modeled.

\section{Digital Model Simulation}

Five-minute rainfall data for approximately five storms per year for 70 years were obtained from the Nationa1 Oceanic and Atmospheric Administration. These data were used to drive the calibrated digital model to simulate a set of peaks for each basin studied; these peaks were then used in a floodfrequency analysis.

Inputs to the simulation program were daily rainfall and evaporation (to determine antecedent moisture conditions), unit rainfall, and the calibrated model parameters. Only one rainfal1 and one evaporation record can be used. Any areal variation in rainfall volume and intensity must be accounted for by direct multipliers to the data input. An annual rainfall adjustment was applied to daily rainfall values, and a rainfa11-intensity adjustment was applied to unit rainfall values. Adjustments used for this project are listed in table 3 and were determined from National Oceanic and Atmospheric Administration isohyetal and isopluvial maps. Because the evaporation record was not as long as the rainfall record, it was synthesized using the existing data patterns.

\section{Mode1 Verification}

Peak-flow data available from Johnson and Saltzman Creeks (14211500 and 14211800) were compared with computer-synthesized peaks to evaluate the statistical reliability of the methods used in this report and to detect any bias. The comparisons were made for periods outside the model calibration period and provided an independent verification of the model results. 


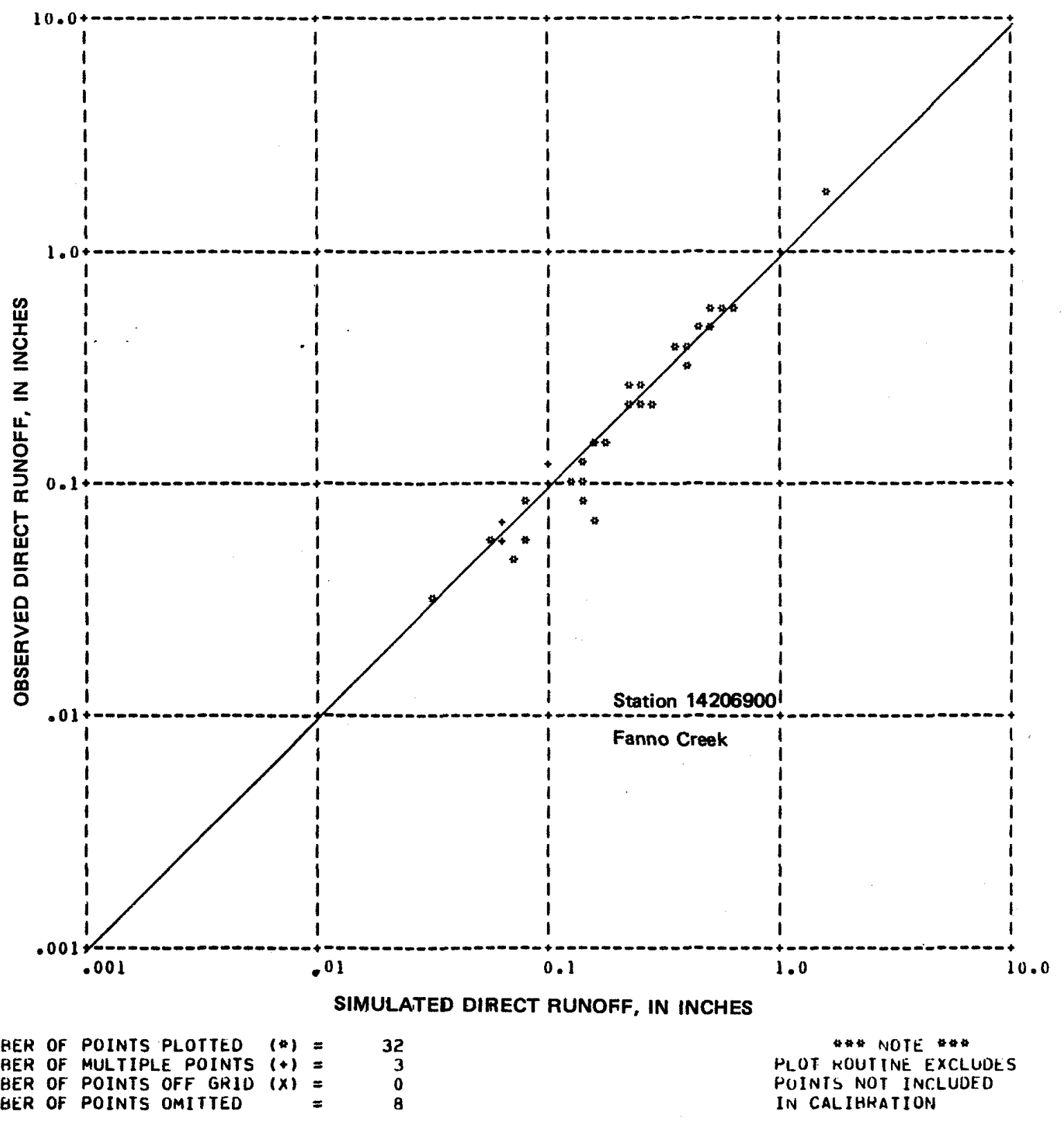

Figure 7.-Example of scatter diagram of model results for storm runoff. 


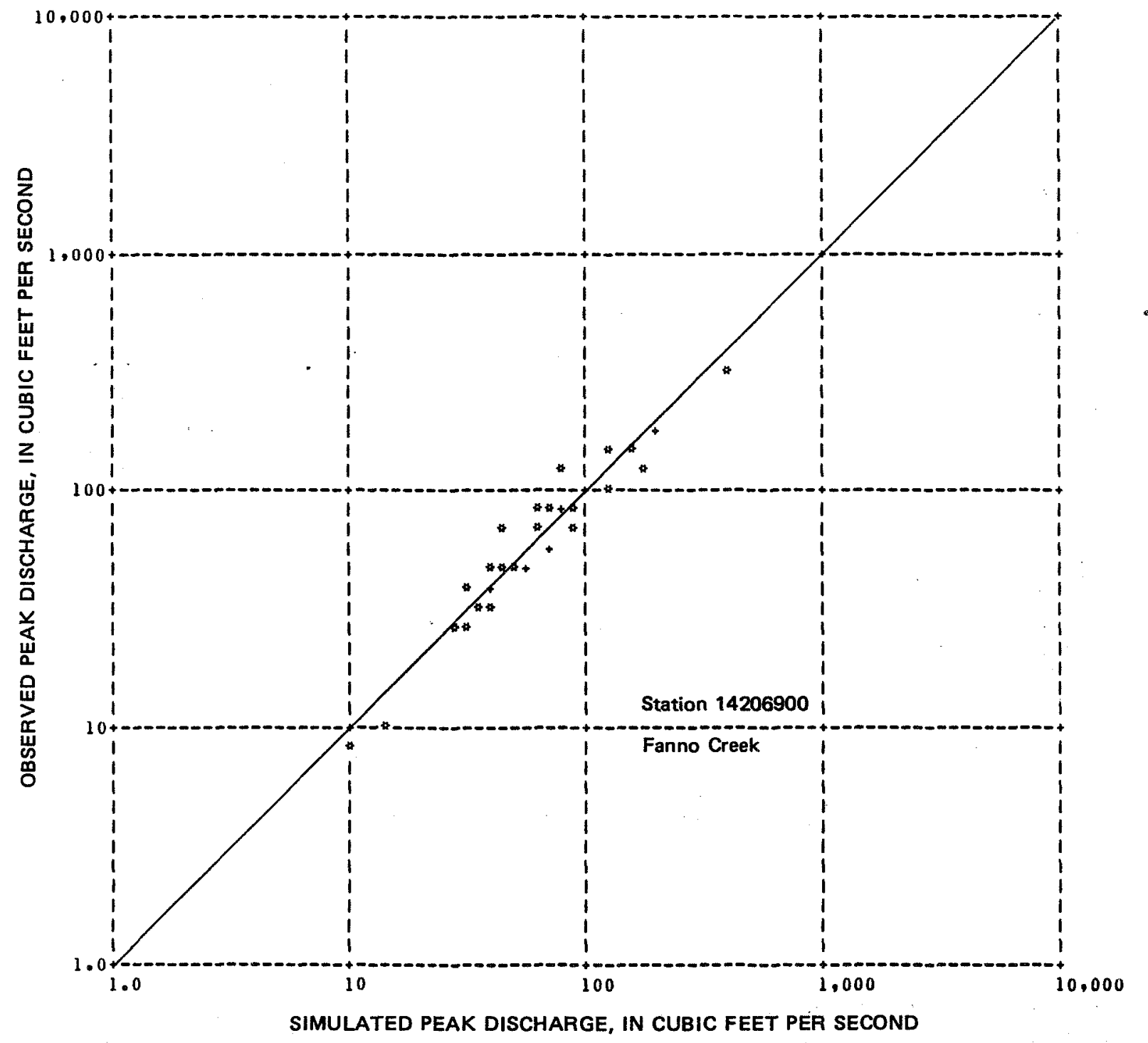

NUMBER OF POINTS PLOTTED (*) = 32

NUMBER OF MULTIPLE POINTS $(+)=5$

NUMBER OF POINTS OFF GRID $(x)=0$

NUMBER OF POINTS OMITTED $=8$ PLOT ROUTINE EXCLUDES
POINTS NOT INCLUDED IN CAL IGRATION

Figure 8.-Example of scatter diagram of model results for peak discharge. 


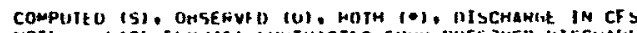

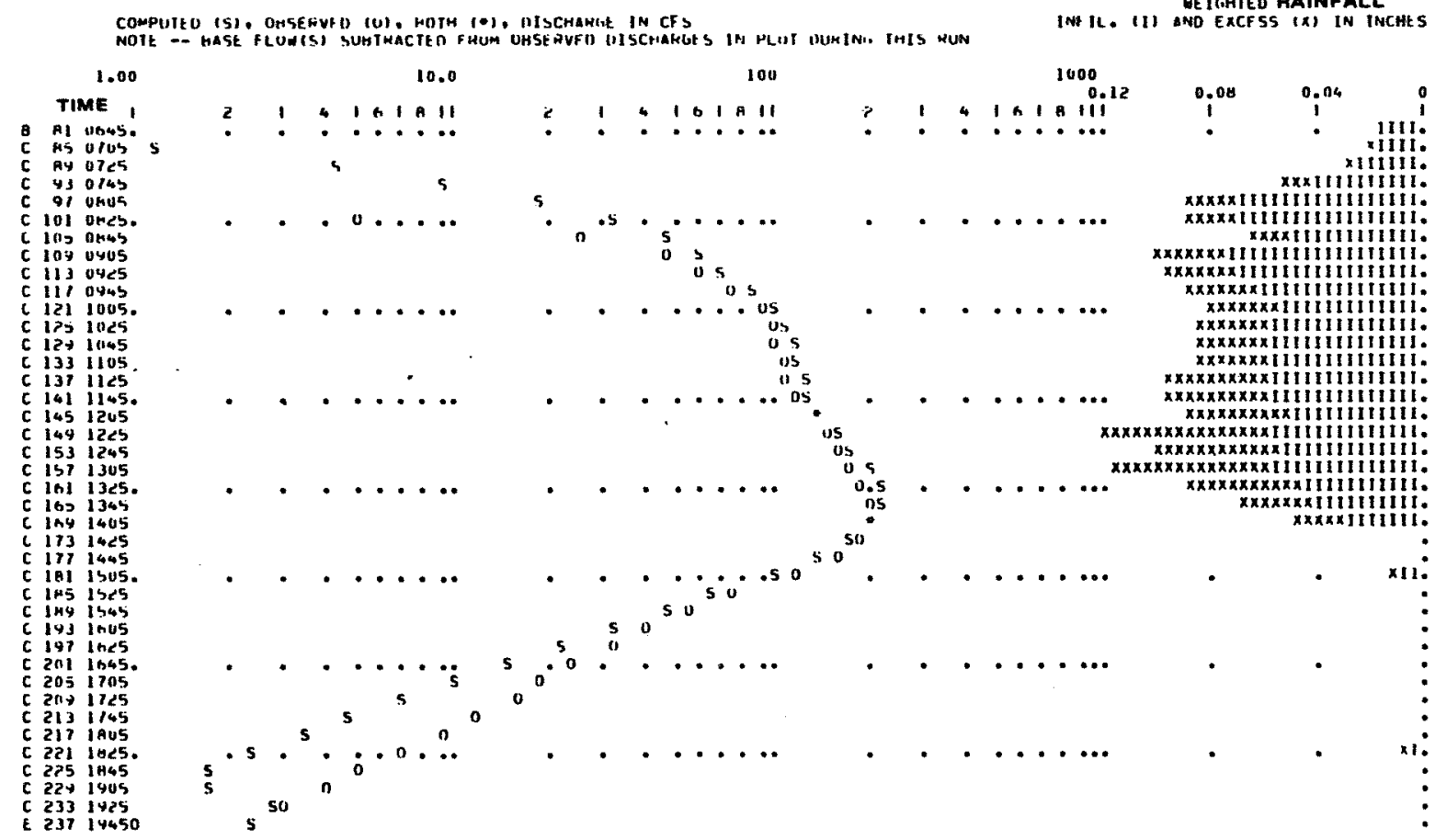

Figure 9.-Storm rainfall and discharge hydrograph.

Johnson Creek, which showed an excellent model calibration, has a large drainage basin. National Weather Service maps indicate that precipitation is 16 percent higher in the Johnson Creek basin than at the location of the rain gage used in synthesis, with at least this much variability for each individual storm. Factors from table 3 were used to adjust historical records in the synthesis. The relation between observed peaks and simulated peaks for Johnson Creek for the period 1949-73 (fig. 10) shows the associated scatter and verifies methods used in this report. The scatter is random, which indicates little, if any, bias. The standard deviation is 30 percent for this relation. Peak-flow data for Saltzman Creek for the period 1952-73 were used in a similar verification. The scatter was random, and the standard deviation was 40 percent. The model calibration for Saltzman Creek is considered to be poor, even with the small SEE shown, because of the small sample size available for calibration. 


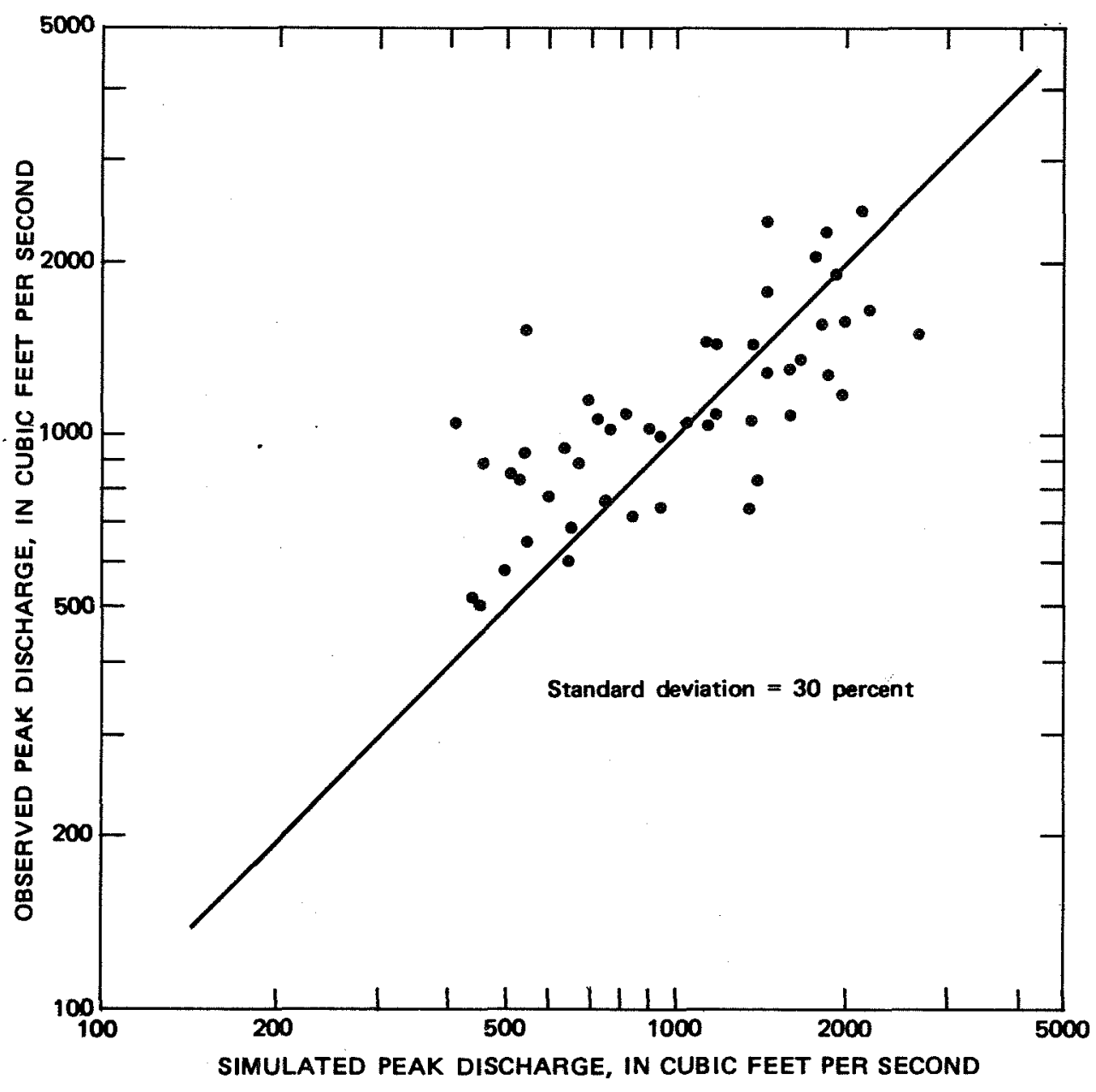

Figure 10.-Johnson Creek (14211500) verification model (1949-73 data plotted).

\section{Peak- and Storm-Runoff Frequency Analyses}

Results of the log-Pearson type-III analyses of peak discharges are presented in table 4. Three sets of computations were made using zero skew, a weighted skew using Water Resources Council (WRC) guidelines, and the station skew to show the variability caused by the use of different skews. The average of all station skews for peak-discharge frequency relations in this area is +0.03 , which is approximately equal to the regional skew of +0.1 and closely approximates zero skew. The weighted skew was based on annual peak flows synthesized from 71 years of rainfall data. This approach is acceptable since the average of the weighted skews, +0.08 , is nearly the same as the averages of the other skews used. Regression analyses covered a11 skew-discharge data included in table 4, and the final regression analysis used the weighted skew. The various regression results were not statistically different, less than 10 percent change in any one coefficient or exponent, and did not decrease the SEE significantly; therefore, these results were not included in this report. 
Table 4. --peak discharges for selected flood frequencies and skews at gaged sites, derived by synthesizing discharge from historical rainfall date (Portland, Oreg., Customs House, 1903-73)

\begin{tabular}{|c|c|c|c|c|c|c|c|c|c|c|c|c|c|c|c|c|c|c|c|c|c|}
\hline \multirow[b]{2}{*}{$\begin{array}{l}\text { Station } \\
\text { number }\end{array}$} & \multicolumn{6}{|c|}{$\begin{array}{l}\text { Peak discharge, in } \mathrm{ft}^{3} / \mathrm{s} \text {, for exceedance prob- } \\
\text { abilities (recurrence interval) at zero skew }\end{array}$} & \multirow{2}{*}{ 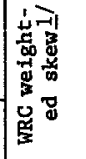 } & \multicolumn{6}{|c|}{$\begin{array}{l}\text { Peak discharge, in } \mathrm{ft}^{3} / \mathrm{s} \text {, for exceedance prob- } \\
\text { abilities (recurrence interva) }\end{array}$} & \multirow{2}{*}{ 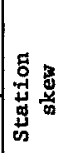 } & \multicolumn{6}{|c|}{$\begin{array}{l}\text { Peak discharge, in } \mathrm{ft} 3 / \mathrm{s} \text {, for exceedance prob- } \\
\text { abilities (recurrence interval) }\end{array}$} & \multirow{2}{*}{$\begin{array}{l}\text { Storm } \\
\text { base } \\
\text { flow } 2 / \\
\left(\mathrm{ft}^{3} / \mathrm{s}\right)\end{array}$} \\
\hline & $\begin{array}{c}0.5 \\
(2 \mathrm{yr})\end{array}$ & $\left(\begin{array}{ll}0.2 \\
(5 \text { yr })\end{array}\right.$ & $\begin{array}{l}0.10 \\
(10 \mathrm{yr})\end{array}$ & $\begin{array}{c}0.04 \\
(25 \mathrm{yr})\end{array}$ & $\begin{array}{c}0.02 \\
(50 \mathrm{yr})\end{array}$ & $\begin{array}{c}0.01 \\
(100 \mathrm{yx})\end{array}$ & & $\begin{array}{c}0.5 \\
(2 . \mathrm{yr})\end{array}$ & $\begin{array}{l}0.2 \\
(5 \mathrm{yr})\end{array}$ & $\begin{array}{c}0.10 \\
(10 \mathrm{yr})\end{array}$ & $\begin{array}{c}0.04 \\
(25 \mathrm{yr})\end{array}$ & $\begin{array}{c}0.02 \\
(50 \mathrm{yr})\end{array}$ & $\begin{array}{c}0.01 \\
(100 \mathrm{yr})\end{array}$ & & \begin{tabular}{|l|}
0.5 \\
$(2 . y r)$
\end{tabular} & $\begin{array}{l}0.2 \\
(5 \mathrm{yx})\end{array}$ & $\begin{array}{c}0.10 \\
(10 \mathrm{yr})\end{array}$ & $\begin{array}{c}0.04 \\
(25 \mathrm{yr})\end{array}$ & $\begin{array}{c}0.02 \\
(50 \mathrm{yr})\end{array}$ & $\begin{array}{c}0.01 \\
(100 \mathrm{yr})\end{array}$ & \\
\hline 14142580 & 276 & 432 & 546 & 702 & 824 & 953 & 0.127 & 273 & 430 & 550 & 718 & 855 & 1,000 & 0.145 & 272 & 430 & 551 & 720 & 859 & 1,010 & 30 \\
\hline & & & & & & & & & 205 & & & & & & 126 & 206 & 260 & 330 & 381 & 432 & 0 \\
\hline 14206320 & 317 & 474 & 586 & 733 & 848 & 966 & -.157 & 321 & 476 & 581 & 715 & 814 & 914 & -.38 & 325 & 477 & 5 & 694 & 779 & 8 & 15 \\
\hline 1420633 & 13 & 19 & 24 & 30 & 35 & 39 & .512 & 12 & 19 & 24 & 32 & 39 & 47 & .772 & 12 & 19 & 24 & 33 & 42 & 51 & 1.5 \\
\hline 14206470 & 51 & 76 & 93 & 117 & 135 & 153 & -.073 & 52 & 76 & 93 & 115 & 132 & 150 & -.182 & 52 & 76 & 93 & 113 & 128 & 144 & 7.0 \\
\hline 14206900 & 212 & 308 & 375 & 461 & 527 & 594 & .034 & 211 & 308 & 376 & 464 & 532 & 601 & -.008 & 213 & 308 & 374 & 460 & 526 & 592 & 30 \\
\hline & 14 & 22 & 27 & 34 & 39 & 45 & .140 & 14 & 22 & 27 & 35 & 41 & 47 & .166 & 14 & 22 & 27 & 35 & 41 & & 2.5 \\
\hline $142104 \mathrm{C}$ & 167 & 222 & 258 & 303 & 336 & 369 & .161 & 165 & 221 & 260 & 310 & 347 & 386 & .15 & 165 & 221 & & 31 & 348 & & 60 \\
\hline 1421111 & 59 & 85 & 102 & 124 & 142 & 159 & .066 & 59 & 84 & 102 & 125 & 143 & 162 & .044 & 59 & 84 & 102 & 125 & 143 & 161 & 15 \\
\hline 14211120 & 38 & 58 & 7.3 & 91 & 106 & 120 & .220 & 37 & 58 & 74 & 95 & 112 & 131 & .296 & 36 & 58 & 75 & 100 & 121 & 145 & 5.0 \\
\hline 14211130 & 92 & 130 & 155 & 187 & 212 & 236 & .239 & 91 & 129 & 156 & 192 & 222 & 252 & .327 & 90 & 129 & 157 & 195 & 227 & 260 & 25 \\
\hline & 36 & 50 & 60 & 71 & 80 & 89 & .386 & 35 & 50 & 60 & 75 & 87 & 100 & .567 & 35 & 49 & 61 & 77 & 90 & 105 & 5.0 \\
\hline 14211450 & 25 & 35 & 42 & 50 & 56 & 63 & -.563 & 26 & 35 & 40 & 46 & 50 & 53 & -.892 & 27 & 35 & 39 & 44 & 46 & 48 & 3.0 \\
\hline 14211500 & 1,310 & 1,830 & 2,180 & 2,620 & 2,960 & 3,300 & .164 & 1,290 & 1,820 & 2,190 & 2,680 & 3,060 & 3,450 & .205 & 1,290 & 1,820 & 2,190 & 2,700 & 3,090 & 3,500 & 300 \\
\hline $3 / 14211500$ & 1,150 & 1,830 & 2,320 & 3,000 & 3,530 & 4,100 & -.097 & 1,160 & 1,830 & 2,320 & 2,970 & 3,480 & 4,000 & -.796 & 1,230 & 1,840 & 2,190 & 2,560 & 2,800 & 3,000 & \\
\hline 14211604 & 249 & 357 & 431 & 527 & 600 & 675 & .205 & 245 & 355 & 435 & 543 & 629 & 720 & .272 & 244 & 354 & 436 & 548 & 638 & 735 & 20 \\
\hline & 23 & & & 516 & 58 & 667 & .211 & 233 & 34 & 423 & 532 & 62 & 712 & .281 & 232 & 342 & 424 & 53 & 631 & & 7.0 \\
\hline 14211614 & 228 & 344 & 42 & 53 & & & .295 & 226 & & 430 & 55 & 64 & & .418 & 221 & 340 & & & & & 5.0 \\
\hline 14211617 & 95 & 141 & 174 & 218 & 2. & 286 & .077 & 94 & 141 & 175 & 220 & 2. & 29 & .0 & 94 & 141 & 1 & 2 & 256 & & 0 \\
\hline 14211618 & 51 & 88 & 118 & 162 & 198 & 237 & -.020 & 51 & 89 & 118 & 160 & 195 & 233 & -.096 & 51 & 89 & 118 & 158 & 191 & 277 & 0 \\
\hline 14211625 & 155 & 245 & 311 & 400 & 472 & 547 & -.091 & 158 & 246 & 306 & 385 & 445 & 504 & -.212 & 158 & 246 & 306 & 384 & 443 & .502 & 3.5 \\
\hline & 10 & 37 & 216 & & & 400 & .016 & 102 & 167 & 216 & & 34 & 402 & -.037 & 102 & 167 & 21 & 28 & 33 & & 2.5 \\
\hline 14211800 & 13 & 180 & 211 & 25 & 27 & 308 & -.181 & 13 & 180 & 21 & 24 & 27 & 29 & -.359 & 136 & 181 & 2 & 23 & 26 & & 25 \\
\hline $4 / 14211800$ & 104 & 168 & 217 & & 34 & 40 & .100 & 104 & 168 & 217 & 28 & 34 & 40 & -.036 & 105 & 169 & 216 & 28 & 330 & 38 & $-\cdots$ \\
\hline & 16 & 25 & 31 & 40 & 47 & 54 & .055 & 16 & 25 & 31 & 40 & 48 & 56 & .027 & 16 & 25 & 31 & 40 & 47 & 55 & 0 \\
\hline 14213040 & 86 & 143 & 186 & 246 & 295 & 348 & .333 & 82 & 143 & 190 & 269 & 334 & 413 & .480 & 82 & 140 & 190 & 270 & 343 & 428 & 12 \\
\hline
\end{tabular}

1/ Time-weighted skew based on guidelines in WRC report (1977).

$\frac{1}{2} /$ Average base flow used in calibration and added to similated peaks.

$\frac{3}{4} /$ Actual discharge data for Johnson Creek (1941-78). 
Included in table 4 are peak discharges based on actual field data for Johnson and Sa1tzman Creeks. These data have been included so that comparisons can be made with modeled data. The modeled frequency curves have 0.01 exceedance-probability peak discharges that deviate by -14 and -27 percent from station discharge values for Johnson Creek and Saltzman Creek, respectively. A better indicator of bias, however, might be obtained by comparing data derived from actual station skews, where the 0.01 exceedance-probability peaks deviate by +17 and -27 percent for Johnson and Saltzman Creeks, respectively. The maximum deviations are generally the same magnitude as the mode1 calibration errors of 20 and 22 percent for Johnson and Saltzman Creeks, respectively. Statistically, areal variability of rainfall is assumed to be eliminated because of the large sample size of the synthetic data used.

Storm runoffs derived using station skew (table 5) were used in the final regression analysis. Skews based on WRC guidelines do not apply to runoff data.

\section{Storm Base Flow}

In this report, base flow during a storm is defined as that component of runoff not attributed to overland flow and is highly variable from storm to storm and from basin to basin. Base flow is influenced by antecedent conditions and can be attributed to the inflow of ground water, interflow between the stream and the unsaturated zone, and return flow from diversions. For combined sewers, the base flow is the flow of sewage.

For the individual model calibrations, base flows were defined by the observed discharge hydrograph. Flows prior to and after the storm event were averaged to define storm base flow for individual peaks. In synthesis, base flow had to be estimated for the individual basins. Because only the larger peaks defined the segment of the log-Pearson type-III frequency curve used in the analysis, the average base flow of the higher peaks was used as the estimate. This estimate was applied uniformly, regardless of peak size, in model synthesis for the individual basin. For peak data in most basins, base flows were normally less than 10 percent of the total flow.

For a few streams at exceedance probabilities between 0.5 and 0.1 , the base-flow component could be higher than the runoff component from overland flow (see table 5).

Storm base-flow variability was analyzed, but no well-defined relation between basin parameters or antecedent conditions could be developed. To accommodate the separation of base flow for storms, two sets of regression equations are provided with and without storm base flow. Subtraction of discharges derived by the two equations is not considered a reliable means for deriving base flow. 
Table 5. --peak-discharge yields and storm runoff for selected flood frequencles at gaged sites, derived by synthesizing from historical rainfall data (Portiand, Oreg.,

Customs House, 1903-73)

\begin{tabular}{|c|c|c|c|c|c|c|c|c|c|c|c|c|c|c|c|c|c|c|c|c|c|}
\hline \multirow[b]{2}{*}{$\begin{array}{l}\text { Station } \\
\text { numbex }\end{array}$} & \multirow{2}{*}{ 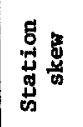 } & \multicolumn{6}{|c|}{$\begin{array}{c}\text { Peak yleld, in }\left(\mathrm{ft}^{3} / \mathrm{s}\right) / \mathrm{mi}^{2} \text {, for exceedance } \\
\text { probabllities (recurrence interva 1) }\end{array}$} & \multirow{2}{*}{ 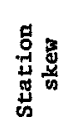 } & \multicolumn{6}{|c|}{$\begin{array}{l}\text { Runoff with base flow, in inches, for exceed- } \\
\text { ance probabilities (recurrence interva1) }\end{array}$} & \multirow{2}{*}{ 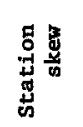 } & \multicolumn{6}{|c|}{$\begin{array}{l}\text { Runoff less base flow, in inches, for exceed- } \\
\text { ance probabilities (recurrence interva) }\end{array}$} \\
\hline & & \begin{tabular}{|l|}
0.5 \\
$(2 \mathrm{yr})$
\end{tabular} & $\begin{array}{c}0.2 \\
(5 \mathrm{yr})\end{array}$ & $\begin{array}{c}0.10 \\
(10 \mathrm{yr})\end{array}$ & $\begin{array}{ll}0.04 \\
(25 \mathrm{yr})\end{array}$ & $\begin{array}{c}0 . \overline{02} \\
(50 \mathrm{yr})\end{array}$ & $\begin{array}{c}0.01 \\
(100 \mathrm{yr})\end{array}$ & & $\begin{array}{ll}0.5 \\
(2 \mathrm{yr})\end{array}$ & $\begin{array}{c}0.2 \\
(5 \mathrm{yr})\end{array}$ & $\begin{array}{c}0.10 \\
(10 \mathrm{yx})\end{array}$ & $\begin{array}{c}0.04 \\
(25 \mathrm{yr})\end{array}$ & $\begin{array}{c}0.02 \\
(50 \mathrm{yr})\end{array}$ & $\begin{array}{c}0.01 \\
(100 \mathrm{yx})\end{array}$ & & $\begin{array}{l}0.5 \\
(2 \mathrm{yr})\end{array}$ & $\begin{array}{c}0.2 \\
(5 \mathrm{yr})\end{array}$ & $\begin{array}{c}0.10 \\
(10 \mathrm{yr})\end{array}$ & $\begin{array}{c}0.04 \\
(25 \mathrm{yr})\end{array}$ & $\begin{array}{c}0.02 \\
(50 \mathrm{yr})\end{array}$ & $\begin{array}{c}0.01 \\
(100 \mathrm{yr})\end{array}$ \\
\hline $\begin{array}{l}14142580 \\
14144690 \\
14206320 \\
14206330 \\
14206470\end{array}$ & $\begin{array}{r}0.145 \\
-.364 \\
-.320 \\
.772 \\
-.182\end{array}$ & $\begin{array}{r}65 \\
126 \\
49 \\
57 \\
63\end{array}$ & $\begin{array}{r}103 \\
206 \\
72 \\
90 \\
93\end{array}$ & $\begin{array}{r}132 \\
260 \\
87 \\
114 \\
113\end{array}$ & $\begin{array}{l}173 \\
330 \\
105 \\
157 \\
138\end{array}$ & $\begin{array}{l}206 \\
381 \\
118 \\
200 \\
156\end{array}$ & $\begin{array}{l}242 \\
432 \\
130 \\
243 \\
176\end{array}$ & $\begin{array}{l}0.131 \\
-.140 \\
-.121 \\
-.301 \\
-.078\end{array}$ & $\begin{array}{r}1.58 \\
.45 \\
1.37 \\
.80 \\
1.48\end{array}$ & $\begin{array}{r}2.39 \\
.87 \\
2.18 \\
1.17 \\
2.26\end{array}$ & $\begin{array}{l}2.99 \\
1.20 \\
2.77 \\
1.42 \\
2.80\end{array}$ & $\begin{array}{l}3.81 \\
1.70 \\
3.55 \\
1.72 \\
3.52\end{array}$ & $\begin{array}{l}4.47 \\
2.11 \\
4.16 \\
1.94 \\
4.07\end{array}$ & $\begin{array}{l}5.18 \\
2.56 \\
4.79 \\
2.16 \\
4.63\end{array}$ & $\begin{array}{l}0.001 \\
-.140 \\
-.334 \\
-.160 \\
-.215\end{array}$ & $\begin{array}{r}0.98 \\
.45 \\
1.26 \\
.25 \\
.75\end{array}$ & $\begin{array}{r}1.67 \\
.87 \\
2.05 \\
.45 \\
1.35\end{array}$ & $\begin{array}{r}2.22 \\
1.20 \\
2.60 \\
.60 \\
1.80\end{array}$ & $\begin{array}{l}2.99 \\
1.70 \\
3.29 \\
.82 \\
2.42\end{array}$ & $\begin{array}{r}3.63 \\
2.11 \\
3.82 \\
.99 \\
2.92\end{array}$ & $\begin{array}{l}4.32 \\
2.56 \\
4.33 \\
1.18 \\
3.45\end{array}$ \\
\hline $\begin{array}{l}14206900 \\
14207800 \\
14210400 \\
14211110 \\
14211120\end{array}$ & $\begin{array}{r}-.008 \\
.166 \\
.199 \\
.044 \\
.296\end{array}$ & $\begin{array}{l}90 \\
50 \\
81 \\
57 \\
49\end{array}$ & $\begin{array}{r}130 \\
79 \\
108 \\
82 \\
78\end{array}$ & $\begin{array}{r}158 \\
96 \\
127 \\
99 \\
101\end{array}$ & $\begin{array}{l}194 \\
125 \\
152 \\
121 \\
135\end{array}$ & $\begin{array}{l}222 \\
146 \\
171 \\
139 \\
164\end{array}$ & $\begin{array}{l}250 \\
171 \\
190 \\
156 \\
196\end{array}$ & $\begin{array}{r}-.235 \\
.329 \\
-.092 \\
.141 \\
.054\end{array}$ & $\begin{array}{l}1.80 \\
1.61 \\
3.42 \\
2.04 \\
1.00\end{array}$ & $\begin{array}{l}2.65 \\
2.54 \\
4.79 \\
3.12 \\
1.60\end{array}$ & $\begin{array}{l}3.21 \\
3.28 \\
5.70 \\
3.93 \\
2.06\end{array}$ & $\begin{array}{l}3.90 \\
4.37 \\
6.83 \\
5.05 \\
2.70\end{array}$ & $\begin{array}{l}4.41 \\
5.30 \\
7.67 \\
5.95 \\
3.21\end{array}$ & $\begin{array}{l}4.92 \\
6.32 \\
8.50 \\
6.92 \\
3.76\end{array}$ & $\begin{array}{l}-.313 \\
.106 \\
-.472 \\
-.153 \\
-.062\end{array}$ & $\begin{array}{r}.78 \\
.81 \\
1.00 \\
.78 \\
.45\end{array}$ & $\begin{array}{r}1.36 \\
1.53 \\
1.80 \\
1.48 \\
.88\end{array}$ & $\begin{array}{l}1.77 \\
2.14 \\
2.37 \\
2.06 \\
1.24\end{array}$ & $\begin{array}{l}2.32 \\
3.08 \\
3.11 \\
2.90 \\
1.78\end{array}$ & $\begin{array}{l}2.74 \\
3.91 \\
3.66 \\
3.60 \\
2.24\end{array}$ & $\begin{array}{l}3.17 \\
4.86 \\
4.20 \\
4.36 \\
2.76\end{array}$ \\
\hline $\begin{array}{l}14211130 \\
14211301 \\
14211450 \\
14211500 \\
14211604\end{array}$ & $\begin{array}{r}.327 \\
.567 \\
-.892 \\
.205 \\
.272\end{array}$ & $\begin{array}{r}37 \\
97 \\
129 \\
49 \\
123\end{array}$ & $\begin{array}{r}53 \\
136 \\
167 \\
69 \\
179\end{array}$ & $\begin{array}{r}65 \\
169 \\
186 \\
83 \\
220\end{array}$ & $\begin{array}{r}81 \\
214 \\
210 \\
102 \\
277\end{array}$ & $\begin{array}{r}94 \\
250 \\
219 \\
117 \\
322\end{array}$ & $\begin{array}{l}107 \\
292 \\
229 \\
132 \\
371\end{array}$ & $\begin{array}{r}.245 \\
-.290 \\
-.182 \\
.114 \\
-.302\end{array}$ & $\begin{array}{l}1.78 \\
1.80 \\
2.38 \\
2.30 \\
1.56\end{array}$ & $\begin{array}{l}2.60 \\
2.68 \\
3.52 \\
3.38 \\
2.39\end{array}$ & $\begin{array}{l}3.21 \\
3.26 \\
4.28 \\
4.16 \\
2.95\end{array}$ & $\begin{array}{l}4.04 \\
3.98 \\
5.24 \\
5.20 \\
3.65\end{array}$ & $\begin{array}{l}4.72 \\
4.50 \\
5.96 \\
6.03 \\
4.17\end{array}$ & $\begin{array}{l}5.44 \\
5.01 \\
6.67 \\
6.89 \\
4.67\end{array}$ & $\begin{array}{l}-.027 \\
-.294 \\
-.536 \\
-.292 \\
-.319\end{array}$ & $\begin{array}{r}.91 \\
.64 \\
1.27 \\
1.36 \\
.75\end{array}$ & $\begin{array}{l}1.56 \\
1.13 \\
2.11 \\
2.26 \\
1.34\end{array}$ & $\begin{array}{l}2.05 \\
1.50 \\
2.67 \\
2.90 \\
1.77\end{array}$ & $\begin{array}{l}2.76 \\
2.00 \\
3.35 \\
3.73 \\
2.35\end{array}$ & $\begin{array}{l}3.33 \\
2.38 \\
3.83 \\
4.36 \\
2.80\end{array}$ & $\begin{array}{l}3.95 \\
2.78 \\
4.29 \\
4.99 \\
3.26\end{array}$ \\
\hline $\begin{array}{l}14211610 \\
14211614 \\
14211617 \\
14211618 \\
14211625\end{array}$ & $\begin{array}{r}.281 \\
.418 \\
.063 \\
-.096 \\
-.212\end{array}$ & $\begin{array}{r}152 \\
162 \\
99 \\
150 \\
259\end{array}$ & $\begin{array}{l}224 \\
250 \\
148 \\
262 \\
403\end{array}$ & $\begin{array}{l}277 \\
319 \\
184 \\
347 \\
502\end{array}$ & $\begin{array}{l}352 \\
421 \\
232 \\
465 \\
630\end{array}$ & $\begin{array}{l}412 \\
508 \\
270 \\
562 \\
726\end{array}$ & $\begin{array}{l}477 \\
604 \\
308 \\
668 \\
823\end{array}$ & $\begin{array}{r}-.069 \\
-.101 \\
.006 \\
-.219 \\
-.263\end{array}$ & $\begin{array}{r}1.34 \\
1.10 \\
.38 \\
.50 \\
1.34\end{array}$ & $\begin{array}{r}2.12 \\
1.83 \\
.66 \\
.92 \\
2.15\end{array}$ & $\begin{array}{r}2.69 \\
2.37 \\
.90 \\
1.25 \\
2.71\end{array}$ & $\begin{array}{l}3.45 \\
3.11 \\
1.23 \\
1.71 \\
3.44\end{array}$ & $\begin{array}{l}4.05 \\
3.70 \\
1.50 \\
2.08 \\
4.00\end{array}$ & $\begin{array}{l}4.68 \\
4.32 \\
1.81 \\
2.48 \\
4.55\end{array}$ & $\begin{array}{r}-.063 \\
-.092 \\
.006 \\
-.219 \\
-.276\end{array}$ & $\begin{array}{l}.91 \\
.82 \\
.38 \\
.50 \\
.88\end{array}$ & $\begin{array}{r}1.56 \\
1.47 \\
.66 \\
.92 \\
1.56\end{array}$ & $\begin{array}{r}2.06 \\
1.97 \\
.90 \\
1.25 \\
2.08\end{array}$ & $\begin{array}{l}2.76 \\
2.70 \\
1.23 \\
1.71 \\
2.78\end{array}$ & $\begin{array}{l}3.34 \\
3.29 \\
1.50 \\
2.08 \\
3.22\end{array}$ & $\begin{array}{l}3.95 \\
3.94 \\
1.81 \\
2.48 \\
3.88\end{array}$ \\
\hline $\begin{array}{l}14211630 \\
14211800 \\
14211950 \\
14213040\end{array}$ & $\begin{array}{r}-.037 \\
-.359 \\
.027 \\
.480\end{array}$ & $\begin{array}{r}189 \\
92 \\
36 \\
29\end{array}$ & $\begin{array}{r}309 \\
122 \\
57 \\
49\end{array}$ & $\begin{array}{r}400 \\
141 \\
70 \\
66\end{array}$ & $\begin{array}{r}524 \\
161 \\
91 \\
94\end{array}$ & $\begin{array}{l}624 \\
176 \\
106 \\
119\end{array}$ & $\begin{array}{l}730 \\
189 \\
125 \\
149\end{array}$ & $\begin{array}{r}-.143 \\
.021 \\
.008 \\
-.132\end{array}$ & $\begin{array}{r}1.06 \\
2.99 \\
.21 \\
.75\end{array}$ & $\begin{array}{r}1.73 \\
4.31 \\
.38 \\
1.16\end{array}$ & $\begin{array}{l}2.21 \\
5.23 \\
.50 \\
1.44\end{array}$ & $\begin{array}{r}2.85 \\
6.43 \\
.69 \\
1.81\end{array}$ & $\begin{array}{r}3.36 \\
7.35 \\
.84 \\
2.09\end{array}$ & $\begin{array}{l}3.88 \\
8.29 \\
1.00 \\
2.37\end{array}$ & $\begin{array}{r}-.148 \\
-.535 \\
.008 \\
-.334\end{array}$ & $\begin{array}{r}.71 \\
1.36 \\
.21 \\
.41\end{array}$ & $\begin{array}{r}1.27 \\
2.31 \\
.38 \\
.72\end{array}$ & $\begin{array}{r}1.71 \\
2.95 \\
.50 \\
.95\end{array}$ & $\begin{array}{r}2.32 \\
3.74 \\
.69 \\
1.26\end{array}$ & $\begin{array}{r}2.82 \\
4.30 \\
.84 \\
1.49\end{array}$ & $\begin{array}{l}3.35 \\
4.84 \\
1.00 \\
1.73\end{array}$ \\
\hline
\end{tabular}




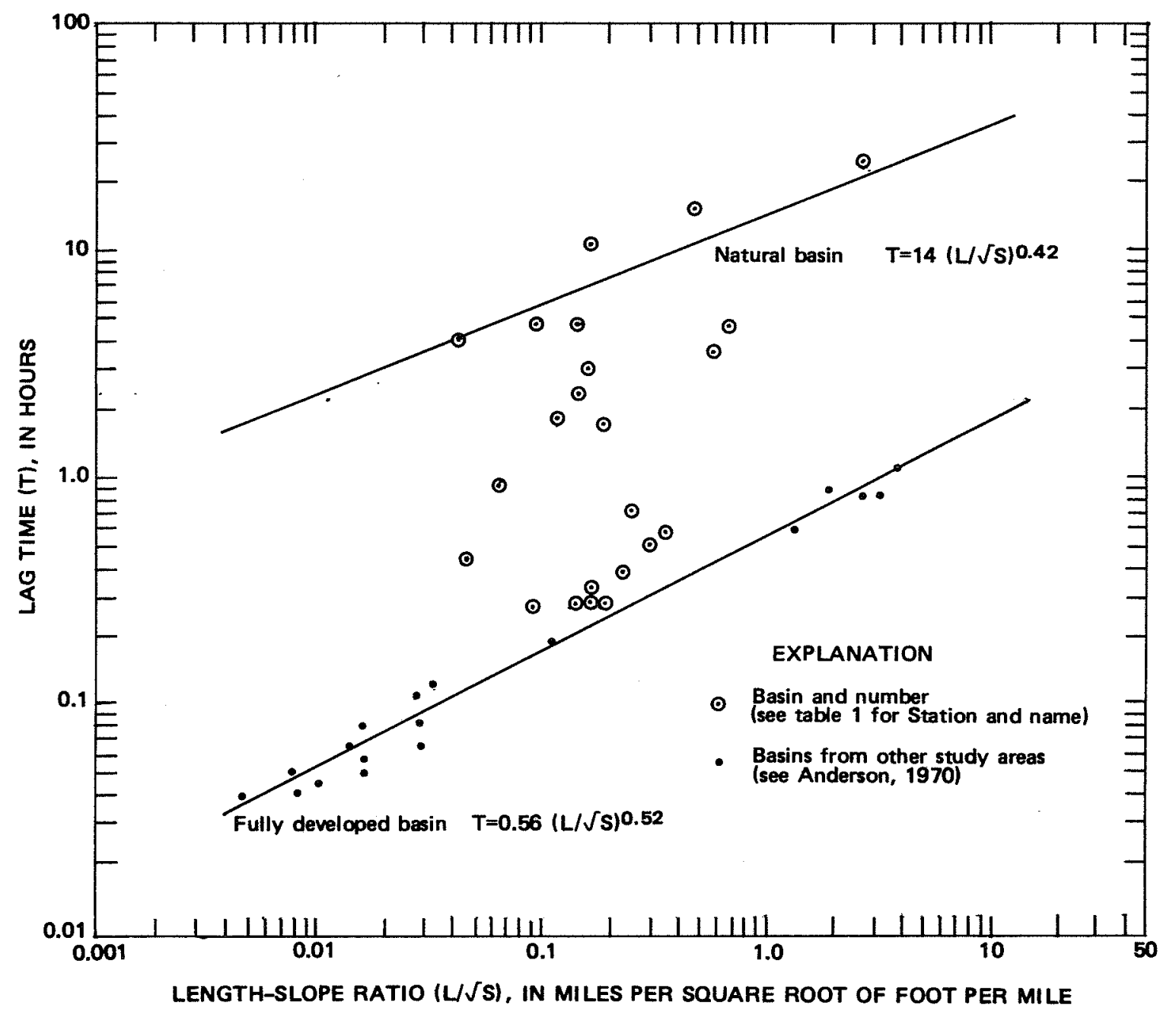

Figure 11.-Relation of lag time to length-slope ratio

\section{Lag-Time Relations}

One of the early analyses made in this study was to define the relation of lag time to the length-slope ratio (channel length divided by the square root of the slope). Relations for basins in this area plotted in a random pattern; some highly developed urban basins showed the same relation as did natural basins. The causes of this random pattern are apparently (1) large differences between the mapped impervious area and its effectiveness, (2) differences in topography associated with the pervious terrace areas which create and modify the response, and (3) man's alterations which do not always improve channel conditions. The relations shown in figure 11 , however, define boundary conditions and are helpful in determining what may be occurring in a basin. The lag-time relation for natural basins in this area is higher than for other basins (Anderson, 1970). Saltzman and Johnson Creeks were used to define the natural relation shown in figure 11, whereas the slope of the line is from relations shown by Anderson (1970). 


\section{UNIQUENESS OF SELECTED INDIVIDUAI BASINS}

Natural and marmade conditions in a basin make it unique in its response to any rainfall event. Each basin studied had to be scrutinized to define its hydraulic conditions so that the analysis used would be valid.

In planning this study, (1) problem basins were excluded, especially those with variable backwater at the proposed gaging site and with upstream storage problems thought to be untypical of the study area; and (2) urban development had to be minima1. Even with this screening of the network, many basin characteristics were less than ideal. Following is a discussion concerning basins that were not ideal, but from which usable data were obtained.

\section{$\underline{\text { Ke11y Creek (14142580) }}$}

Urban development in Kelly Creek was extensive during the period of data collection. Mapped impervious area increased from 9 to about 16 percent of the total area. Because not enough data were collected to provide a large statistical sample to define different periods, the calibrated model used all peaks collected and a "median" relation was developed. It appears, however, that the magnitude for the lower peaks modeled increased about 60 percent from 1975 to 1978. The SEE for model calibration for this basin was greater than for other basins, probably because of the increase in urban development.

\section{Vancouver Sewer (14144690)}

Early calibrations of the Vancouver sewer basin showed that something was amiss with the impervious value determined by mapping techniques. A field survey revealed that many of the roofs in this basin, as well as in much of the Vancouver area, drained directly into dry wells. However, field assessment to determine the volume of water drained into dry we11s for any one storm event is difficult. Dry wells in this area have been in use for at least 30 to 75 years, collecting organic material and clogging the gravel. Many downspout tiles have overflow holes, and all tiles can overflow if they are plugged or if their infiltration rates are exceeded. For field-estimating purposes, a11 roofs and paved areas were subtracted from the total impervious area where overflow drained onto lawns. No attempt was made to modify the size of the drainage area that is effectively smaller because of the use of dry wells. In other parts of the basin, paved areas drained into unimproved ditches and swales and were subtracted from the total impervious area. The remaining impervious areas of streets, sidewalks, some downtown buildings, and the freeway are directly connected by a storm-sewer system.

\section{Beaverton Creek (14206320)}

Peak discharges for this site are modified significantly because of upstream storage caused by several undersized culverts in the main channel. Volume data are not affected. The magnitude of this anomaly was not realized until the basin was modeled. An excellent simulation was defined, as shown by the high correlation coefficient (table 3); however, the extremely long lag time (fig. 11) and low peak yields (table 4) were inconsistent considering 
basin size. This inconsistency might be considered to be an example of the urban paradox where channel modifications reduce peak flows and back up water. In addition to the storage created by channel modifications, Beaverton Creek has substantial storage in lakes and reservoirs, and some storage in detention facilities. The effect of new county codes requiring detention-storage facilities for new construction cannot be assessed at this time.

The log-Pearson type-III frequency analysis for peak discharges for this basin is probably valid to at least the 0.04 exceedance probability. For less than 0.04 exceedance probability, it can be postulated that the stored water will likely either back up or overflow. At what probability this will occur or to what magnitude is unknown unless a detailed backwater analysis is made. When flood-plain storage ( 0.9 percent) is excluded from the equation computation, regression equations developed later in this report show a 20-percent increase in peak magnitude for the 0.01 exceedance-probability peak.

\section{Beaverton Creek Tributary (14206330)}

Peak discharges for the Beaverton Creek tributary site are slightly modified because of detention-storage facilities in the basin. Only about 1 acre is in detention storage within the basin; however, because of the sma11 total drainage involved, it has a significant impact on peak flows. Additional storage area is created by natural depressions and low areas.

\section{Butternut Creek (14206470)}

Urban development in the Butternut Creek basin increased extensively during the period of data collection. The mapped impervious area increased from 8 to about 12 percent of the total area. Al1 peak discharges were used to define the median relation. In contrast to Kelly Creek for the same datacollection period, no difference in flood magnitudes was detected from 1975 to 1978. Differences in soil and natural vegetation between the two areas may have lessened the impact of urbanization in this area.

\section{Singer Creek (14207800)}

As in the Beaverton Creek basin, the Singer Creek basin has reduced peak flows and increased lag times compared to most urban basins. Much of the storage in Singer Creek basin is variable, however, and is primarily caused by debris continually clogging upstream culverts and sewers. This stream is typical of urban streams with deep canyons and "high-fill" culvert crossings. Also typical is the fact that considerable urban refuse finds its way into the stream channels, thereby impeding flow through the culverts. A significant number of peaks at the stream-gage location at Singer Creek had to be deleted from the record because of debris jams caused by refuse. Because of these storage problems, the SEE for the model calibration of Singer Creek was greater than that for most other sites. Debris jams also caused considerable loss of data at other stream-gage locations. 
$\underline{\text { Kellogg Creek, Vancouver Lake Tributary, and Cougar Creek (14211130), }}$ $14211950,14213040)$

The Kellogg Creek, Vancouver Lake tributary, and Cougar Creek basins are a11 on terraces. Topographic depressions in the terrace surfaces restrict drainage and store water in each basin. In Vancouver Lake tributary and Cougar Creek, this stored water is lost to the streamflow system so that peak storm volumes are decreased (see table 4). City sewer gages for areas on the terrace also record decreased runoff volumes. Kellogg Creek, however, eventually receives most of the water stored in depressions back through interflow, as indicated by the large storage component (KSW) of its hydrograph. Kellogg Creek basin also has additional storage in the form of manmade ponds and natura1 marshes along its channe1. Cougar Creek has a minor amount of storage caused by backwater at small culverts in the upper basin.

\section{Tryon Creek Tributary (14211301)}

A significant segment of the Tryon Creek tributary basin loses rainwater through improper connections of roof drains to the sanitary-sewer system. Although this condition occurs frequently in many basins, it is more extensive in this basin than in most others. Six percent of the basin, or 17 percent of the impervious area, is affected, according to a study by the city of Portland Department of Public Works, Bureau of Sanitary Engineering.

\section{Saltzman Creek (14211800)}

Saltzman Creek basin was the only totally forested basin and also the steepest basin in the study area (table 1). Because vegetation and forest litter provided significant water retardation and storage, only the longest duration rainstorms had sufficient runoff to model. Rain from thunderstorms was absorbed in the basin with virtually no runoff, and light winter rains tended only to increase base flow. When the basin was saturated, however, peak flows were high in magnitude because of fast runoff from the steep terrain. The runoff hydrograph is complicated by the presence of a storage reservoir (generally full in winter) and an undersized culvert in the upper basin.

\section{REGIONALIZATION OF FLOOD-PEAK AND STORM-RUNOFF CHARACTERISTICS}

Peak discharges and runoff volumes, determined by $10 \mathrm{~g}$-Pearson type-III analyses, were regressed against basin parameters. Effective impervious area proved to be a better indicator of urbanization than mapped impervious area, decreasing the SEE by approximately 10 percent. The combination of land-uses $I$ and II and street-gutter density had a good correlation with effective impervious area ( $R$ - square $=0.804$ and $\mathrm{SEE}=32$ percent). The equation is as follows: $E T A=25$ LU12-0.29 (GUTR +0.1$)^{0.16}$. The land-use and gutter parameters, regressed in separate analyses to define peak discharge and storm runoff, showed sensitivities and SEE's similar to those using the effective impervious area parameter. A11 basin parameters defined in this report were included in the regression analyses; however, only those that were statistically significant and that improved results are included in the regression 
results shown in tables 7 through 12 . The following equations are extracted from tables 7 through 12 because they have acceptable SEE's and utilize the most practical basin characteristics available:

Equation 8, table 8.--Peak discharge, in cubic feet per second, for exceedance probabilities shown (recurrence intervals are shown in parentheses):

$$
\begin{aligned}
& Q_{0.5}(2 \mathrm{yr})=79 \mathrm{DA}^{0.93} \mathrm{LU12}{ }^{-0.12}\left(\mathrm{GUTR}^{0.1}\right)^{0.05}(\mathrm{ST}+0.1)^{-0.27} \\
& \mathrm{Q}_{0.2}(5 \mathrm{yr})=127 \mathrm{DA}^{0.93} \mathrm{LU12}-0.14(\text { GUIR }+0.1)^{0.06}(\mathrm{ST}+0.1)^{-0.26} \\
& \mathrm{Q}_{0.1}(10 \mathrm{yr})=.162 \mathrm{DA}^{0.94} \mathrm{LU12}-0.16 \text { (GUTR+0.1) } 0.06(\mathrm{ST}+0.1)^{-0.25} \\
& \mathrm{Q}_{0.04}(25 \mathrm{yr})=214 \mathrm{DA}^{0.94} \mathrm{LU12}-0.17(\text { GUTR+0.1 })^{0.07}(\mathrm{ST}+0.1)^{-0.24} \\
& \mathrm{Q}_{0.02}(50 \mathrm{yr})=256 \mathrm{DA}^{0.93 \mathrm{LU12}}-0.18(\mathrm{GUTR}+0.1)^{0.07}(\mathrm{ST}+0.1)^{-0.23} \\
& Q_{0.01}(100 \mathrm{yr})=303 \mathrm{DA}^{0.94} \mathrm{LU12}-0.19(\text { GUTR+0.1 })^{0.08}(\mathrm{ST}+0.1)^{-0.22}
\end{aligned}
$$

The above equations yield an average $R$-square of 0.97 and have an average SEE of 23 percent. Figure 12 is the residual plot for the individual basins at the 0.5 exceedance-probability level.

Equation 5, table 10.--Storm runoff, less base flow, in inches, for exceedance probabilities shown:

$$
\begin{aligned}
& R_{0.5}(2 \mathrm{yr})=0.39(\mathrm{RI}-1.7)^{0.70} \mathrm{BSL}^{0.34} \mathrm{LU12}^{-0.07} \\
& \mathrm{R}_{0.2}(5 \mathrm{yr})=0.48(\mathrm{RI}-1.7)^{0.60} \mathrm{BSL}^{0.39} \mathrm{LU}^{-0.11} \\
& \mathrm{R}_{0.1}(10 \mathrm{yr})=0.66(\mathrm{RI}-\mathrm{I} .7)^{0.60} \mathrm{BSL}^{0.39} \mathrm{LU} 12^{-0.12} \\
& \mathrm{R}_{0.04}(25 \mathrm{yr})=0.96(\mathrm{RI}-1.7)^{0.60} \mathrm{BSL}^{0.38} \mathrm{LU12}^{-0.13} \\
& \mathrm{R}_{0.02}(50 \mathrm{yr})=1.22(\mathrm{RI}-1.7)^{0.60} \mathrm{BSL}^{0.37} \mathrm{LU}^{-0.13} \\
& \mathrm{R}_{0.01}(100 \mathrm{yr})=1.52(\mathrm{RI}-1.7)^{0.59} \mathrm{BSL}^{0.36} \mathrm{LU}^{-0.14}
\end{aligned}
$$

The above equations yield an average $R$-square of 0.62 and have an average SEE of 32 percent. Figure 13 is the residual plot for the individual basins at the 0.5 exceedance-probability leve1. 
DEVIATION, IN PERCENT

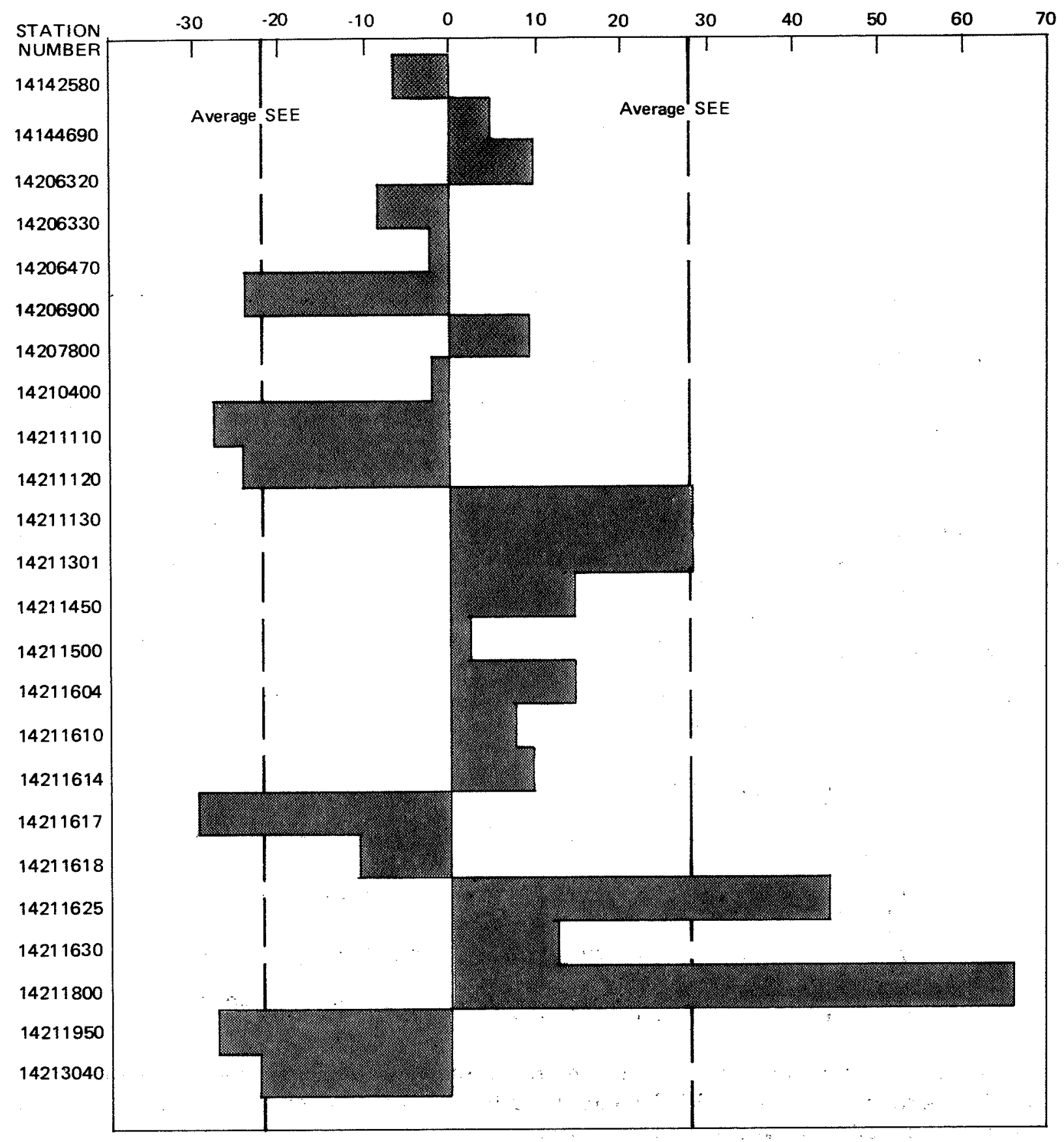

Figure 12.- Residuals of peak discharge for 0.5 exceedance probability for individual basins 
DEVIATION, IN PERCENT

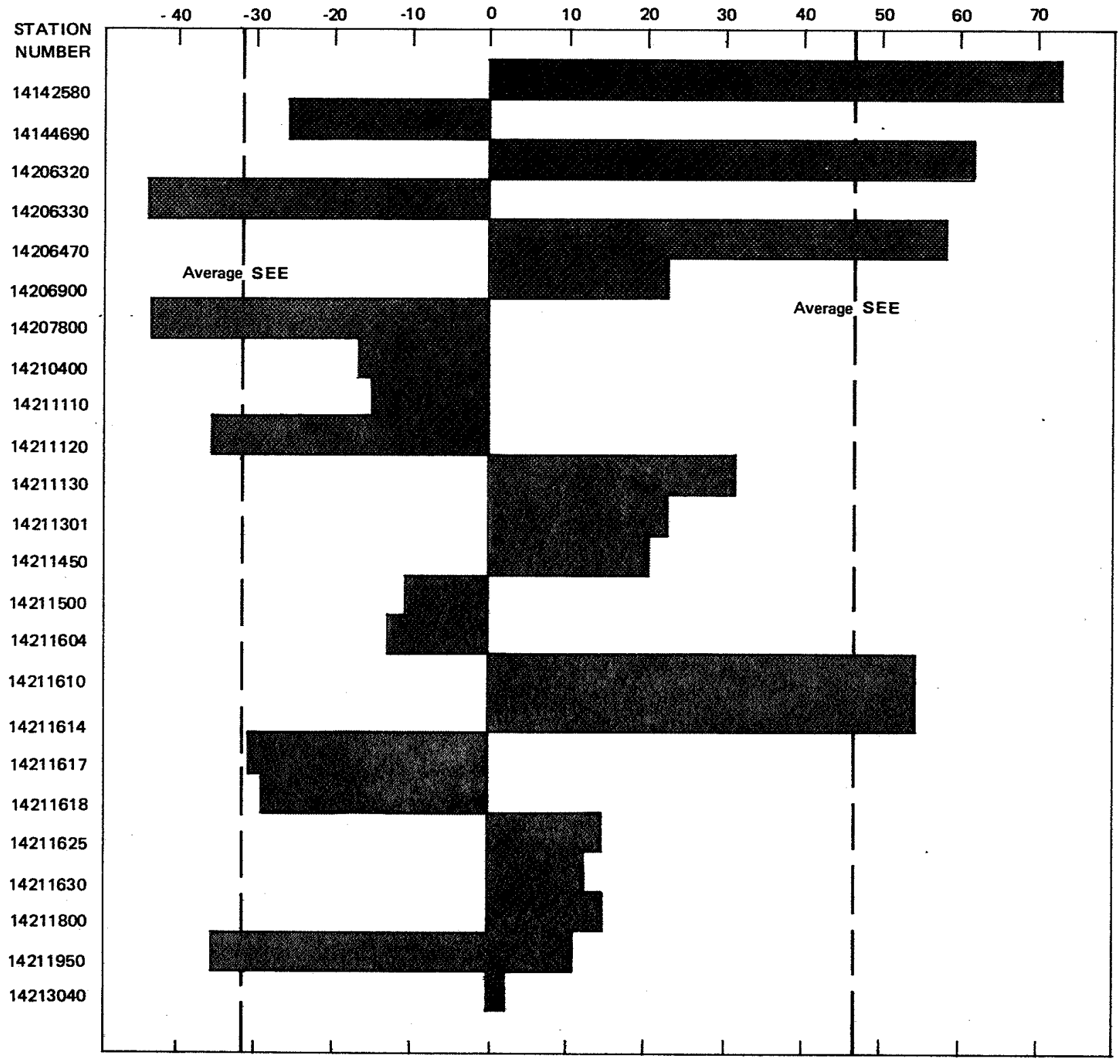

Figure 13.-Residuals of storm runoff for 0.5 exceedance probability for individual basins. 
Equation 7, table 12.--Storm runoff, with base flow, in inches, for the exceedance probabilities shown:

$$
\begin{aligned}
& \mathrm{R}_{0.5}(2 \mathrm{yr})=0.078(\mathrm{RI}-1.7)^{0.49} \mathrm{BSL}^{0.44} \mathrm{LU12}^{-0.15_{\text {INFL }}}{ }^{-0.72} \\
& \mathrm{R}_{0.2}(5 \mathrm{yr})=0.17(\mathrm{RI}-1.7)^{0.49_{\mathrm{BSL}^{0}}}{ }^{0.42} \mathrm{LU12}^{-0.15_{\text {INFL }}-0.61} \\
& R_{0.1}(10 \mathrm{yr})=0.26(\mathrm{RI}-1.7)^{0.50_{\mathrm{BSL}}}{ }^{0.41_{\mathrm{LU} 12}-0.16_{\text {INFL }}}-0.55 \\
& R_{0.04}(25 \mathrm{yr})=0.41(\mathrm{RI}-1.7)^{0.51_{\mathrm{BSL}}}{ }^{0.40_{\mathrm{LU12}}}{ }^{-0.15_{\text {INFL }}}-0.49 \\
& \mathrm{R}_{0.02}(50 \mathrm{yr})=0.54(\mathrm{RI}-1.7)^{0.52} \mathrm{BSL}^{0.40_{\mathrm{LU} 12}-0.15_{\mathrm{INFL}}-0.44} \\
& \mathrm{R}_{0.01}(100 \mathrm{yr})=0.69(\mathrm{RI}-1.7)^{0.53_{\mathrm{BSL}}}{ }^{0.40_{\mathrm{LU12}}}{ }^{-0.15_{\text {INFL }}}-0.40
\end{aligned}
$$

The above equations yield an average $R$-square of 0.68 and have an average SEE of 37 percent.

Equation 3 from both tables 8 and 10 can be used instead of the foregoing equations if the user feels he has enough data to accurately define the effective impervious area. Adequate field surveys can be made, but this requires considerable time and expense.

A1I regression equations shown in this report have associated standard errors of estimate and should be used only within the range of values shown in table 1 (p.13) to be within this standard error.

\section{Example}

The foregoing equations can be used to determine the peak discharge and the runoff volume of an event having a 0.04 exceedance probability (25 yr) for a basin in the Portland area, and the following is an example to illustrate the use of the equations: From a topographic map, the drainage boundary is defined and the drainage area determined to be $2.85 \mathrm{mi}^{2}$. The map shows no definable area in lakes, ponds, depressions, nor detention-storage facilities, and none is known to be in the basin. Forests, parks, agriculture, and vacant lots can be determined from MSD land-use maps or from aerial photography. The LU12 is found to be 53 percent. From city or county drainage maps or aerial photography, streets with gutters and catch basins can be determined. Measure their total length, multiply by 2 if both sides of the street have gutters, and divide by the total drainage area. The gutter density is found to be $12 \mathrm{mi} / \mathrm{mi}^{2}$. Add 0.1 to this value. Now these values can be substituted into the discharge equation:

$$
\begin{aligned}
Q_{0.04}(25 \mathrm{yr}) & =214(2.85)^{0.94}(53)^{-0.17}(12.1)^{0.07}(0.1)^{-0.24} \\
& =603 \mathrm{ft}^{3} / \mathrm{s}
\end{aligned}
$$

Therefore, a discharge of $600 \mathrm{ft}^{3} / \mathrm{s}$ has one chance in 25 of being exceeded in any one year in this basin. 
Storm runoff (less base flow) can now be calculated for this same basin. Basin slope is computed from a topographic map and is determined to be $290 \mathrm{ft} / \mathrm{mi}$. The 50-year, 6-hour rainfal1 intensity obtained from the isopluvial map (National Weather Service, 1973) or figure 2 of this report averaged $1.9 \mathrm{in}$. for this basin. Subtract $1.7 \mathrm{in}$. from this value. Now these values can be substituted into the volume equation:

$$
\begin{aligned}
& \mathrm{R}_{0.04}(25 \mathrm{yr})=0.96(0.2)^{0.60}(290)^{0.38}(53)^{-0.13} \\
& =1.88 \mathrm{in} \text {. }
\end{aligned}
$$

Therefore, 1.9 in. of runoff will have one chance in 25 of being exceeded in any one year in this basin. This value, however, does not include the base flow of the stream.

Storm runoff with base flow for the example above, including the infiltration rate of $0.10 \mathrm{in.} / \mathrm{h}$, can be calculated as follows:

$$
\begin{aligned}
\mathrm{R}_{0.04}(25 \mathrm{yr}) & =0.41(0.2)^{0.51}(290)^{0.40}(53)^{-0.15}(0.10)^{-0.49} \\
& =2.97 \mathrm{in} .
\end{aligned}
$$

Therefore, $3.0 \mathrm{in}$. of runoff, including base flow, will have one chance in 25 of being exceeded in any one year in this basin.

As noted on page 27, subtraction of discharges computed from the last two equations above is not a reliable means of deriving base flow.

\section{Sensitivity}

Regression equations were used to determine the sensitivity of physical basin parameters in the study area. Specific parameters were varied while all other parameters were held constant. Equations utilizing both the land-use and street-gutter parameters (recommended equations) and the effective impervious area (alternative equations) were used in this analysis. To examine the effect of each parameter, realistic maximum and minimum parameter values were substituted in the equations and the results compared. Table 6 shows these results.

Table 6 can be roughly interpreted (by evaluating the EIA parameter and the LU12 and GUTR parameters) to show that the change, caused by urbanization, from a natural basin (minimum parameter value) to a fully developed basin (maximum parameter value) will increase peak discharge more than threefold, whereas storm runoff will increase twofold. In addition to the sensitivity of storage shown in table 6 , figure 14 shows graphically how storage will affect peak discharge in a 1-square-mile basin. For example, figure 14 shows that when 1 percent of the basin area is used for storage, the peak discharge for 0.09 exceedance probability is decreased approximately 40 percent and that when 10 percent of the basin is used for storage, peak discharge is decreased approximately 70 percent. Similar decreases apply to larger and smaller basins in the study area for other exceedance probabilities. 
Table 6.--Sensitivity analysis of parameters in regression equations

\begin{tabular}{|c|c|c|c|c|c|c|c|c|c|c|}
\hline \multirow[b]{2}{*}{ Parameter name } & \multicolumn{2}{|c|}{ eak discharge equations } & \multicolumn{6}{|c|}{$\begin{array}{l}Q_{e p}=a D^{b} \cdot E_{A}^{c}(S T+0.1)^{d} \\
\left.Q_{e p}=e D A^{f} \text { LU128 (GUIR }+0.1\right)^{h}(S T+0.1)^{k}\end{array}$} & & \multirow{2}{*}{$\begin{array}{l}\text { Average percent } \\
\text { range of } \\
\text { discharge }\end{array}$} \\
\hline & $\begin{array}{l}\text { Acro- } \\
\text { nym }\end{array}$ & \multicolumn{2}{|c|}{$\begin{array}{l}\text { Range of parameter values } \\
\text { expected in study area }\end{array}$} & \multicolumn{6}{|c|}{$\begin{array}{c}\text { Percent range in discharge }(Q) \text { for selected } \\
\text { exceedance probabilities (ep) resulting } \\
\text { from range in parameter values } \\
\end{array}$} & \\
\hline Effective impervious area & EIA & 50 percent & 2 percent & 280 & 320 & 340 & 390 & 410 & 440 & 360 \\
\hline $\begin{array}{l}\text { Land uses I and II (forests, } \\
\text { parks, agriculture, vacant } \\
\text { lots) } \\
\text { Street-gutter density }\end{array}$ & $\begin{array}{l}\text { LU12 } \\
\text { GUIR }\end{array}$ & $\begin{array}{l}1 / 1 \text { percent } \\
60 \mathrm{mi} / \mathrm{mi}^{2}\end{array}$ & $\begin{array}{l}1 / 99 \text { percent } \\
0 \mathrm{mi} / \mathrm{mi}^{2}\end{array}$ & 240 & 280 & 310 & 340 & 360 & 400 & 320 \\
\hline Storage & ST & 10 percent & 0.1 percent & -71 & -70 & -68 & -67 & -65 & -64 & -68 \\
\hline Drainage area & $\mathrm{DA}$ & $30 \mathrm{mi}^{2}$ & $0.2 \mathrm{mi}^{2}$ & 1,100 & 1,100 & 1,100 & 1,100 & 1,100 & 1,100 & 1,100 \\
\hline . & & \multicolumn{8}{|c|}{ 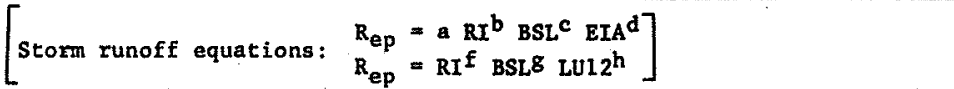 } & \\
\hline & Acro- & \multicolumn{2}{|c|}{$\begin{array}{l}\text { Range of parameter values } \\
\text { expected in study area }\end{array}$} & \multicolumn{6}{|c|}{$\begin{array}{l}\text { Percent range in runoff (R) for selected } \\
\text { exceedance probabilities (ep) resulting } \\
\text { from range in parameter values }\end{array}$} & $\begin{array}{l}\text { Average percent } \\
\text { range of }\end{array}$ \\
\hline Paxameter name & & Kaximum & Minimum & 0.5 & 0.2 & 0.1 & 0.04 & 0.02 & 0.01 & runoff \\
\hline Effective impervious area & ELA & 50 percent & 2 percent & 250 & 240 & 240 & 230 & 230 & 230 & 240 \\
\hline $\begin{array}{l}\text { Land uses I and II (forests, } \\
\text { parks, agriculture, vacant } \\
\text { lots) }\end{array}$ & LU12 & $1 / 1$ percent & $\underline{1} / 99$ percent & 140 & 170 & 170 & 180 & 180 & 190 & 170 \\
\hline Rainfall intensity & RI & $3.0 \mathrm{in} . / 6 \mathrm{~h}$ & $1.8 \mathrm{in} .16 \mathrm{~h}$ & 600 & 470 & 470 & 470 & 470 & 450 & 490 \\
\hline Basin slope & BSL & $2,000 \mathrm{ft} / \mathrm{mi}$ & $80 \mathrm{ft} / \mathrm{mi}$ & 300 & 350 & 350 & 340 & 330 & 320 & 330 \\
\hline
\end{tabular}

1/ LO12, is used as an inverse indication of uxbanization; therefore, maximum urbanization is a minimum percentage of land uses I and II. 


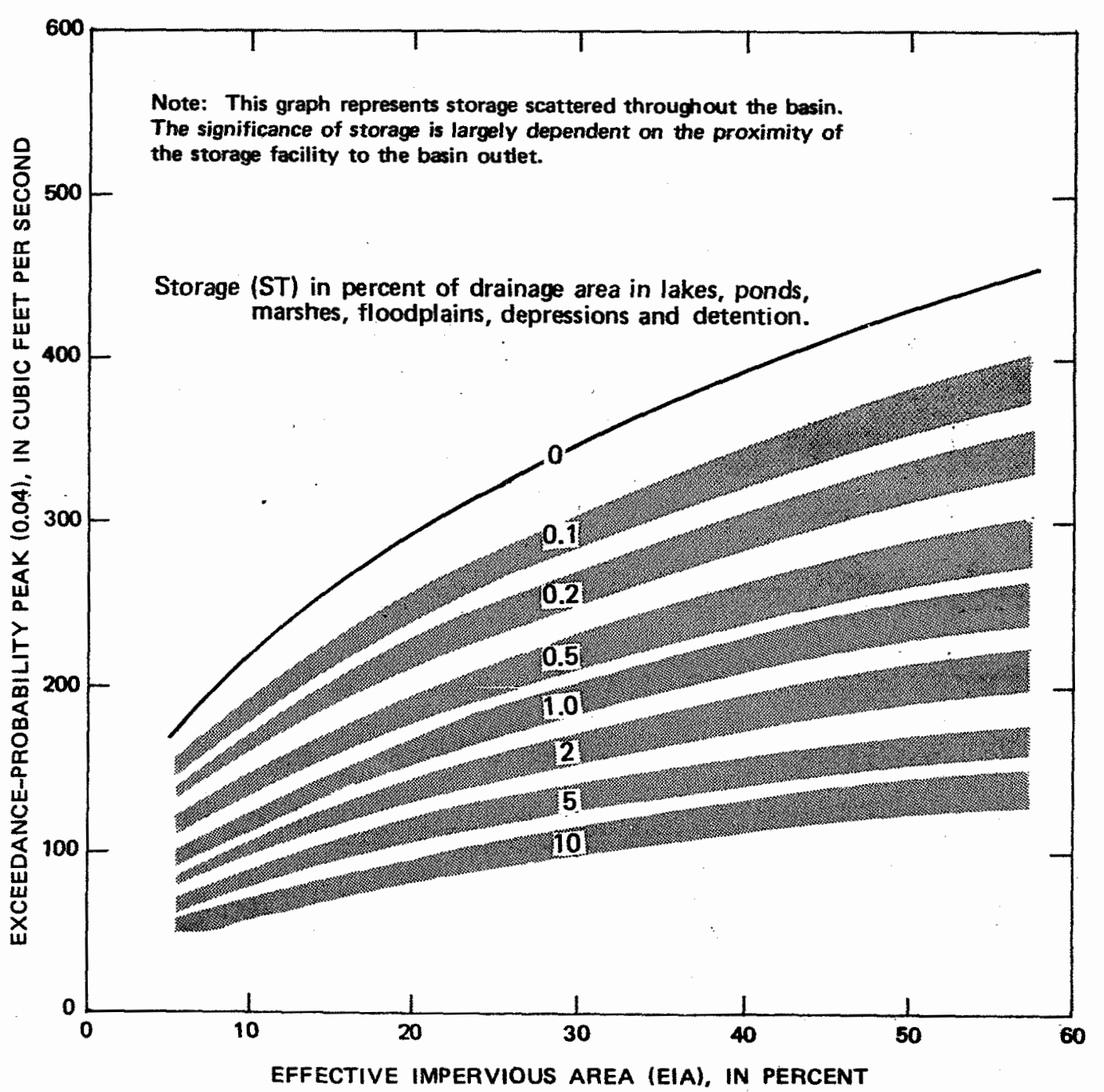

Figure 14.-Sensitivity of storage for basins of one square mile.

\section{ASSESSMENT OF PEAK DISCHARGES FOR HISTORIC EXIREMES PRIOR TO PERIOD OF STUDY}

As noted in the "Rainfa11 Characteristics" section of this report, two 24-hour extremes have been recorded outside the period of record used to synthesize the frequency analysis and generate the regression equations. Do these storms significantly affect the relations developed? This was evaluated by relating historic storm events to discharges from the long-term gaging station on Johnson Creek (14211500).

Realizing that spatial variations in rainfa11 will exist between the Customs House and Johnson Creek drainage, and recognizing that Johnson Creek has a response ( $\mathrm{lag}$ time $=25 \mathrm{hr}$ ) close to 24 hours, peak discharges versus 24-hour storm extremes for Johnson Creek can be plotted for all winter events. This data plot yields a fair relation (fig. 15). Data that were used to calibrate the model of Johnson Creek are plotted and show less scatter than the previous data mentioned, probably because there is no spatial variation in rainfa11 (rainfa11 data are weighted data from three drainages in the Johnson Creek basin). A lower boundary can be estimated for these relations and can 


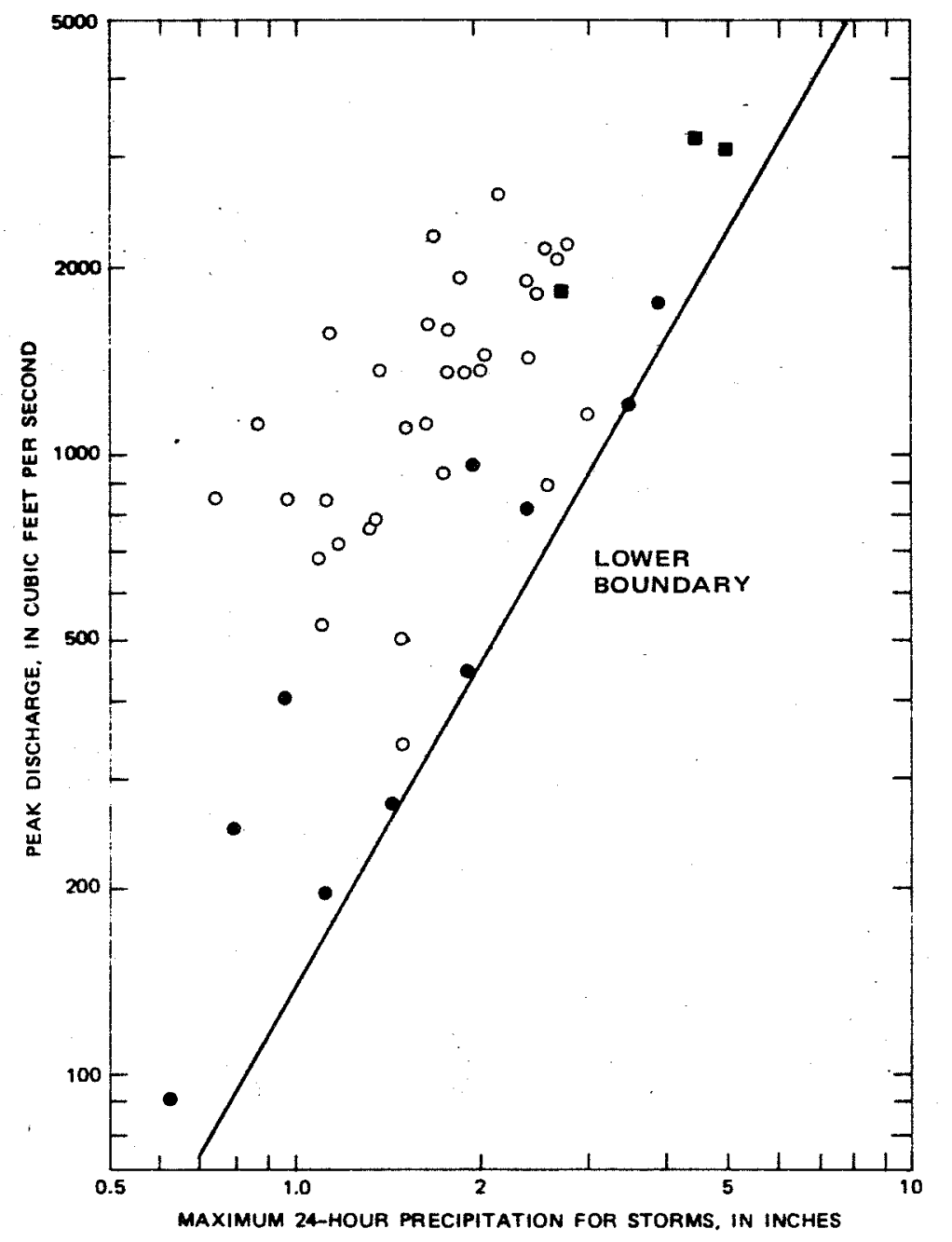

EXPLANATION

\begin{tabular}{c|c|c}
\hline SYmbol & \multicolumn{1}{|c|}{ Precipitation dats } & Peak-discharge dato \\
\hline & From U.S. Customs House & $\begin{array}{l}\text { Meximum synthesized historic } \\
\text { peals }(1903-73)\end{array}$ \\
\hline 0 & From U.S. Custorns House & Observed peaks (1949-73) \\
\hline 0 & $\begin{array}{l}\text { Weighted average from } \\
\text { rain geges in besin }\end{array}$ & $\begin{array}{l}\text { Oberved pealo (1974-78) } \\
\text { used in model calibration }\end{array}$ \\
\hline
\end{tabular}

Figure 15.-Relation of maximum 24-hour precipitation to peak discharge for Johnson Creek. 
be extended to the 7.66-inch extreme of 1882, from which a corresponding discharge can be estimated. Thus, it can be stated with some confidence that, under present conditions, a storm with the intensity of the December 1882 storm on Johnson Creek would yield a discharge of at least $5,000 \mathrm{ft} / \mathrm{s}$. A discharge of this magnitude would be the largest in at least the last 105 years, and larger than the 100-year log-Pearson type-III frequency peak discharge. Papers and periodicals of 1882 substantiate that this was an extreme event to some degree. The Oregonian newspaper of Thursday, December 14, 1882 , V. XXII, listed among other flood statistics the fact that there was major flooding on Johnson Creek, with some sewers and sidewalks gone. River rises on the Willamette, Tualatin, and Yamhil1 Rivers were extreme, reportedly ranging from 4 in. per. hour to 1 ft per hour, and stages were high, washing out many railroad bridges along these streams and their tributaries. Tanner Creek, in west Portland, washed out the bridge on Canyon Road (Oregon State Highway 26). Fatalities were reported, along with considerable property damage, among the Chinese community living along the creek. Newspaper articles indicated that the storm probably never exceeded an hourly rate of 0.4 in. (1-hour duration, 2-yr frequency).

No we11-defined relations exist between 24-hour extremes and peak discharges for basins smaller than the Johnson Creek basin, because the small basins respond more quickly. Excellent relations, however, can be established by correlating shorter duration extreme precipitation with peak discharges. For example, figure 16 relates the 1-hour maximum intensity to peak discharge for Fanno Creek (Fanno Creek has a lag time of $1.2 \mathrm{hr}$ ).

The inclusion of historic storm events in the storm analysis did not significantly change any of the analyses, except for Johnson Creek. Imposing a historic peak of $5,000 \mathrm{ft}^{3} / \mathrm{s}$, with a known period of at least 105 years of record $3 /$, on the log-Pearson type-III flood-frequency analysis for Johnson Creek, results in a curve that shows slightly higher results than the systematic (station) curve (see fig. 17). This trend is also valid for slightly larger drainage areas. The December 188248 -hour extreme of 10.75 in. also indicates that larger basins may have experienced a more extreme peak. LogPearson results for Johnson Creek, regardless of the skew or the inclusion of an estimated peak of record, show the estimated peak for 1882 may have been at least a 500-year event.

\section{CONCLUSIONS}

Urban development brings with it impervious cover and generally improved storm-drainage systems. Man does his best to drain water from his property during storm events. His design for accelerating storm-water drainage is varied and complex and sometimes inadequate.

3/ The 105 years is a minimum period of record. The interval between peaks of this magnitude may be much longer. 


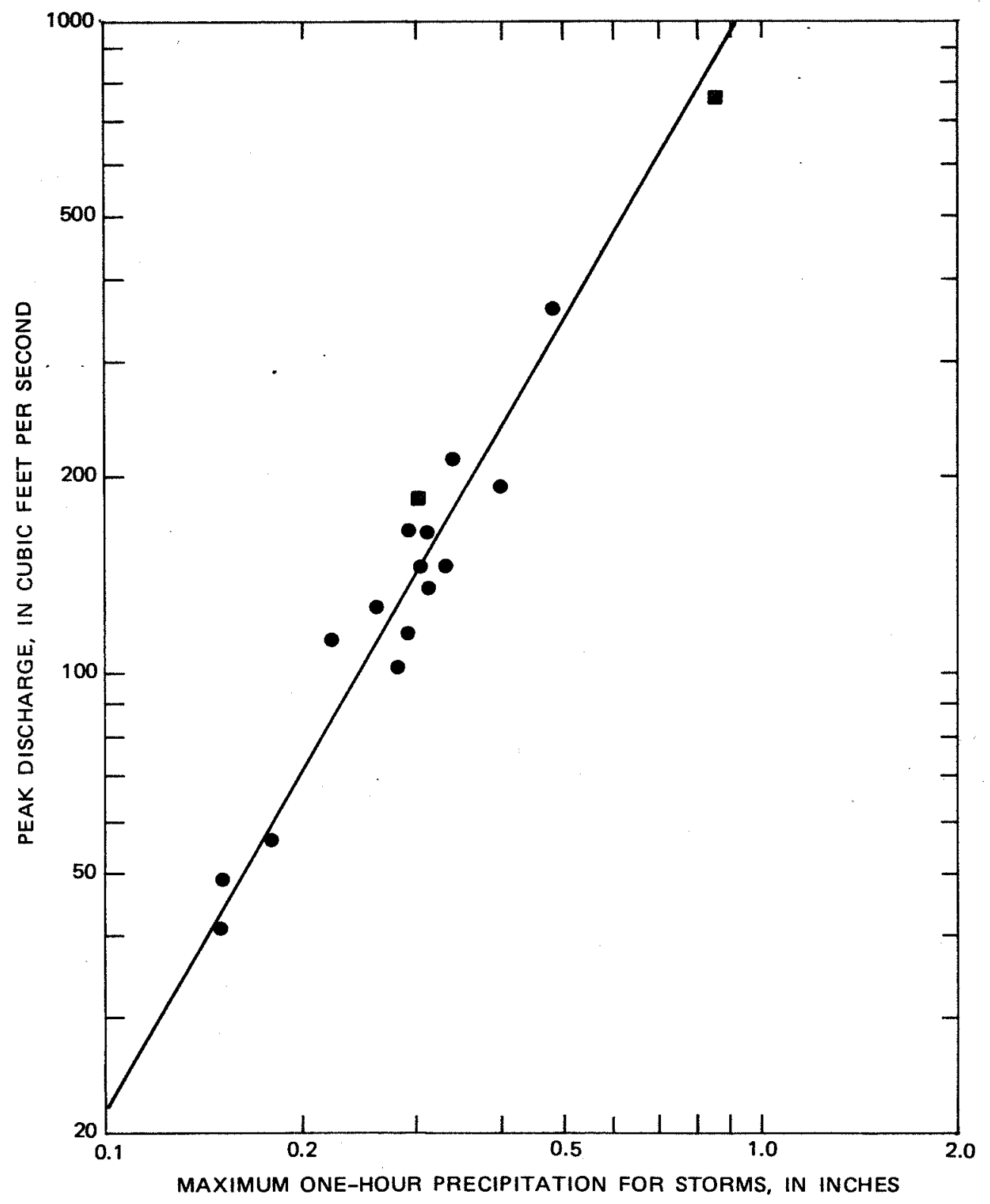

EXPLANATION

\begin{tabular}{c|l|l}
\hline Symbol & \multicolumn{1}{|c|}{ Precipitation data } & Peak-discharge data \\
\hline$\square$ & From U.S. Customs House gage & $\begin{array}{l}\text { Maximum synthesized } \\
\text { historic peaks (1903-73) }\end{array}$ \\
\hline$\bullet$ & $\begin{array}{l}\text { Weighted average from } \\
\text { gages in basin }\end{array}$ & $\begin{array}{l}\text { Observed peaks (1974-78) } \\
\text { used in model calibration }\end{array}$ \\
\hline
\end{tabular}

Figure 16.-Relation of maximum one hour precipitation to peak discharge for Fanno Creek. 


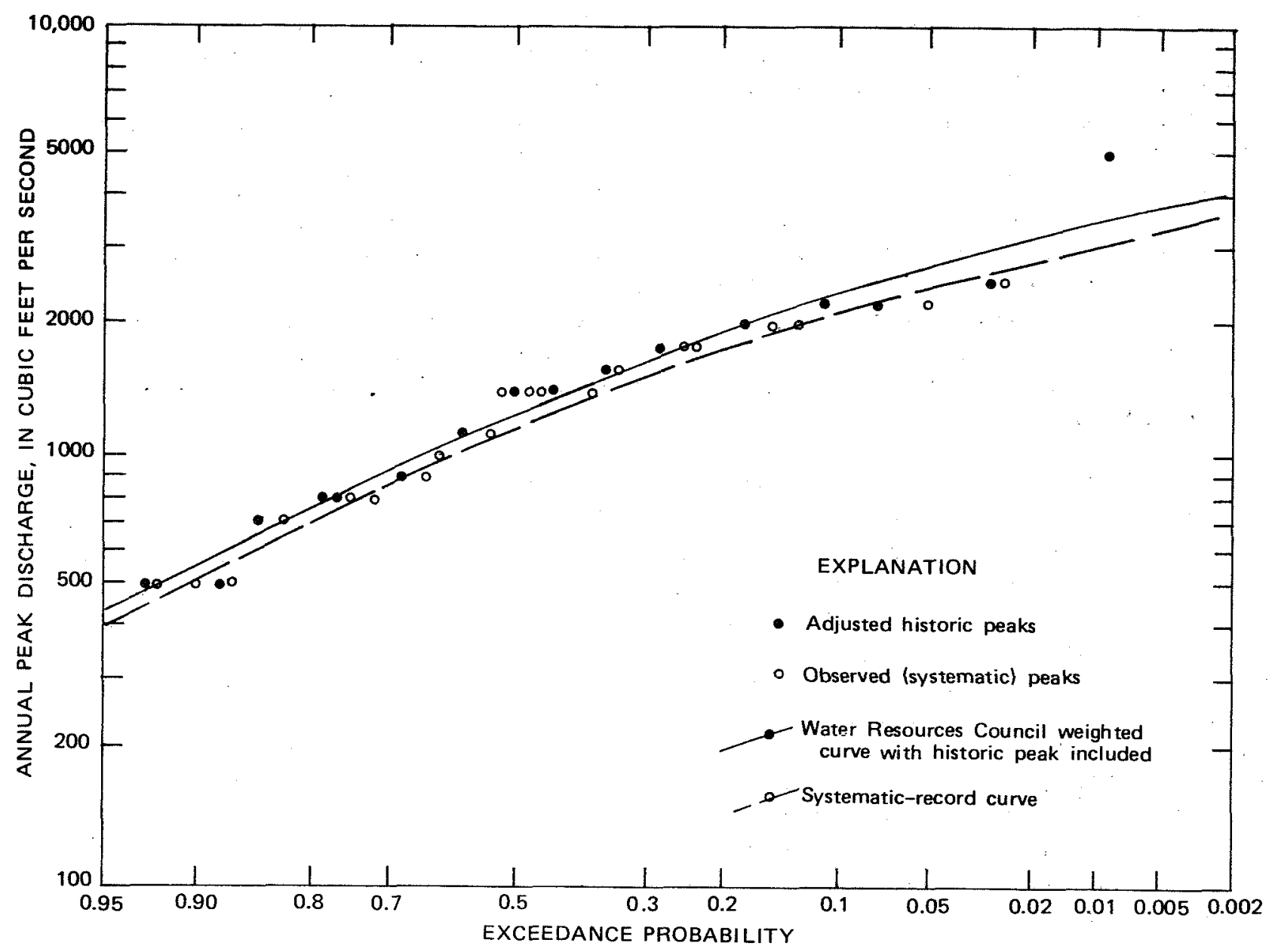

Figure 17.- Log Pearson Type-III frequency curves for Johnson Creek.

In this study, the best index of urbanization in a basin was found to be effective impervious area, which is related to the total impervious cover and its linkage to the main channel (or trunk sewer). Effective impervious area can be costly to determine because of the time involved to measure this basin characteristic in the field. For most basins in this report, a digital model was used to approximate this characteristic.

Effective impervious area, although developed in this report, is not recommended for use by most users in estimating peak flows at ungaged sites. The combination of land uses I and II and the street-gutter density in a basin shows significant correlation to effective impervious area and is recommended as a substitute index of urbanization. Land uses $I$ and II, which categorize al1 forest, park, agricultura1, and vacant-lot land uses, prove to be an inverse indicator of urban development. Street-gutter density, with somewhat less significance than land uses I and II, helps to identify the effects of the increased response of an urban basin. Current maps are available through city and county agencies to define both land-use and street-gutter parameters. 
Storage, as defined in this report, proved to be another significant parameter affecting runoff in the Portland-Vancouver area. However, graphs and percentages shown in this report should be used only as estimates. Storage was sma11 compared to the overal1 drainage, but it influenced discharge considerably. The proximity of the storage to the outlet of the basin was not considered. Several basins with significant area in storage coincidentally had culverts that would restrict high flows. Only six of the basins studied had significant amounts of storage. Al1 these factors combined tend to reduce the accuracy to which this parameter can be predicted from data in this report. Wherever possible, detention storage was included in total storage; however, detention storage proved to be a significant part of the total in only one basin. This'study shows that storage will reduce peak flows significantly.

A variety of local conditions were sampled to make the statistical analysis for this study as valid as possible. The average standard error of estimate for all model calibrations was approximately 30 percent. The verification analysis of the simulation and the regression error analysis showed a similar standard error. The verification analysis indicated that little bias was introduced from digital-model calibration and simulation. Regression equations are shown on pages 33 and 36 of this report. Peak-discharge equations have an associated average SEE of 23 percent, storm-runoff (less base flow) equations have an average SEE of 32 percent, and storm-runoff (with base flow) equations have an average SEE of 37 percent. A sensitivity analysis of these equations is given on pages 37 and 38 of this report. This analysis shows that a fully developed urbanized basin in the Portland area will have peak discharge three times greater and storm runoff two times greater than a natura1 basin. 
Table 7.--Summary of statistics for regression analysis of peak discharge for selected exceedance probabilities (recurrence intervals)

\begin{tabular}{|c|c|c|c|c|c|c|c|c|c|c|c|c|c|c|c|c|c|c|c|c|c|}
\hline \multirow{3}{*}{$\begin{array}{c}\text { Equa- } \\
\text { tion } \\
\text { no. }\end{array}$} & \multicolumn{10}{|c|}{ Exceedance probability 0.5 (2-year) } & \multirow{3}{*}{$\begin{array}{l}\text { Equa- } \\
\text { tion } \\
\text { no. }\end{array}$} & \multicolumn{10}{|c|}{ Exceedance probability 0.04 (25-year) } \\
\hline & \multicolumn{8}{|c|}{ Parameter "F" value } & \multirow[b]{2}{*}{$\begin{array}{c}\text { R- } \\
\text { square }\end{array}$} & \multirow[b]{2}{*}{$\begin{array}{l}\text { Avg } \\
\text { SEE }\end{array}$} & & \multicolumn{8}{|c|}{ Parameter "F" value, } & \multirow[b]{2}{*}{$\begin{array}{c}R- \\
\text { square }\end{array}$} & \multirow[b]{2}{*}{$\begin{array}{l}\text { Avg } \\
\text { SEE }\end{array}$} \\
\hline & $\mathrm{DA}$ & EIA & LU12 & GUTR & ST & $\mathrm{BSL}^{1 /}$ & $\mathrm{RI}^{1} /$ & $\operatorname{INFL}^{\prime}$ & & & & DA & EIA & LU12 & GUTR & ST & $\mathrm{BSL}=1 /$ & $\mathrm{RI}^{1} /$ & INFL $\underline{\underline{1}}$ & & \\
\hline 1 & 74 & -- & -- & -- & -- & -- & -- & -- & 0.771 & 57.6 & 1 & 68 & -- & -- & -- & -- & -- & -- & -- & 0.757 & 58.5 \\
\hline 2 & 102 & 7.8 & -- & -- & -- & -- & -- & -- & .833 & 49.8 & 2 & 114 & 13.4 & - & -- & -- & $\cdots$ & - & - & .851 & 45.9 \\
\hline 3 & 433 & 17.9 & -- & -- & 67.2 & -- & - - & -- & .962 & 23.8 & 3 & 431 & 32.1 & -- & -- & 57.6 & -- & -- & -- & .962 & 23.3 \\
\hline 4 & 432 & 18.3 & -- & -- & 70.2 & 1.75 & -- & - & .965 & 23.3 & 4 & 403 & 22.7 & -- & -- & 55.4 & 0.19 & -- & -- & .962 & 23.8 \\
\hline 5 & 392 & 20.7 & - & -- & 55.6 & -- & 1.93 & - & .965 & 23.2 & 5 & 379 & 32.7 & - & -- & 46.8 & -- & 1.08 & -- & .964 & 23.3 \\
\hline 6 & 412 & 10.8 & - & -- & 64.0 & -- & -- & 0.25 & .962 & 24.2 & 6 & 485 & 17.4 & -- & -- & 62.7 & -- & -- & 3.40 & .967 & 22.0 \\
\hline 7 & 361 & -- & 12.2 & -- & 47.4 & $\cdots$ & -- & -- & .955 & 25.8 & 7 & 383 & -- & 25.6 & -- & 38.5 & $\cdots$ & $\cdots$ & - & .956 & 25.0 \\
\hline 8 & 384 & -- & 4.4 & 2.3 & 51.8 & $\cdots$ & -- & -- & .960 & 24.9 & 8 & 482 & -- & 10.7 & 6.2 & 50.8 & - & $\cdots$ & - & .967 & 22.2 \\
\hline
\end{tabular}

Exceedance probability 0.2 (5-year)

Exceedance probability 0.02 (50-year)

\begin{tabular}{|c|c|c|c|c|c|c|c|c|c|c|c|c|c|c|c|c|c|c|c|c|c|}
\hline 1 & 72 & - & -- & - & -- & -- & -- & -- & .766 & 57.6 & 1 & 67 & $=-$ & -- & - & -- & -- & -- & -- & .754 & 58.7 \\
\hline 2 & 108 & 10.2 & $-\cdots$ & -- & -- & $\cdots$ & -- & $\cdots$ & .842 & 47.7 & 2 & 117 & 14.8 & - & -- & -- & - & - & -- & .855 & 45.1 \\
\hline 3 & 456 & 25.3 & - & -- & 66.9 & -- & -- & - & .964 & 22.8 & 3 & 409 & 33.7 & -- & - & 51.8 & -- & -- & -- & .960 & 23.9 \\
\hline 4 & 437 & 21.3 & -- & $\cdots$ & 66.7 & .87 & $\cdots$ & -- & .965 & 22.9 & 4 & 380 & 22.7 & $\cdots$ & -- & 49.5 & .07 & - & $\cdots$ & .960 & 24.5 \\
\hline 5 & 411 & 27.8 & -- & -- & 55.2 & -- & 1.74 & - & .967 & 22.4 & 5 & 356 & 33.3 & $\cdots$ & -- & 41.8 & $\sim$ & .80 & $-\overline{1}$ & .961 & 24.0 \\
\hline 6 & 463 & 13.8 & -- & -- & 66.9 & -- & - & 1.40 & .966 & 22.6 & 6 & 477 & 18.3 & - & -- & 58.1 & - & -- & 4.19 & .967 & 22.1 \\
\hline 7 & 389 & $\cdots$ & 18.7 & -- & 45.8 & -- & -- & -- & .957 & 24.7 & 7 & 368 & $\cdots$ & 27.2 & - & 34.1 & -- & -. & -- & .954 & 25.5 \\
\hline 8 & 450 & -- & 7.2 & 4.2 & 54.9 & -- & -- & -- & .965 & 22.9 & 8 & 475 & $\cdots$ & 11.6 & 6.9 & 46.5 & $\cdots$ & $\ldots$ & -- & .966 & 22.4 \\
\hline \multicolumn{11}{|c|}{ Exceedance probability 0.10 (10-year) } & \multicolumn{11}{|c|}{ Exceedance probability 0.01 (100-year) } \\
\hline 1 & 70 & -- & -- & - & -- & -- & -- & $\cdots$ & .761 & 58.3 & 1 & 66 & -- & - & -- & $\cdots$ & -- & -- & -- & .750 & 59.1 \\
\hline 2 & 110 & 11.4 & -- & -- & -- & -- & -- & - & .845 & 47.2 & 2 & 120 & 16.2 & -- & -- & -- & -- & -- & -- & .859 & 44.5 \\
\hline 3 & 456 & 29.0 & -- & -- & 65.5 & -- & -- & -- & .964 & 22.8 & 3 & 383 & 34.7 & -- & -- & 45.9 & -- & - & -- & .957 & 24.6 \\
\hline 4 & 431 & 22.3 & -- & $\cdots$ & 64.0 & .48 & -- & -- & .965 & 23.1 & 4 & 357 & 22.4 & - & -- & 43.6 & .01 & $\cdots$ & -- & .957 & 25.2 \\
\hline 5 & 406 & 30.7 & $\cdots$ & -- & 53.7 & -- & 1.42 & -- & .966 & 22.6 & 5 & 331 & 33.1 & - & $m$ & 37.0 & -- & .52 & -- & .958 & 24.9 \\
\hline 6 & 486 & 15.6 & -- & - & 68.1 & - & -- & 2.30 & .968 & 22.1 & 6 & 459 & 18.9 & -- & -- & 52.5 & - & $\cdots$ & 4.73 & .966 & 22.5 \\
\hline 7 & 399 & -- & 22.5 & $\cdots$ & 44.6 & - & -- & -- & .958 & 24.5 & 7 & 350 & -- & 28.4 & -- & 29.8 & -- & - & -- & .952 & 26.2 \\
\hline 8 & 476 & -- & 9.1 & 5.0 & 55.5 & -- & $\cdots$ & -- & .967 & 22.4 & 8 & 457 & -- & 12.3 & 7.2 & 41.3 & -- & $\cdots$ & -- & .965 & 22.8 \\
\hline
\end{tabular}

1/. Outside of 95 percent significance level. 
Table 8.-- Summary of regression-equation coefficients and exponents for peak discharge for selected exceedance probabilities (recurrence interva1s)

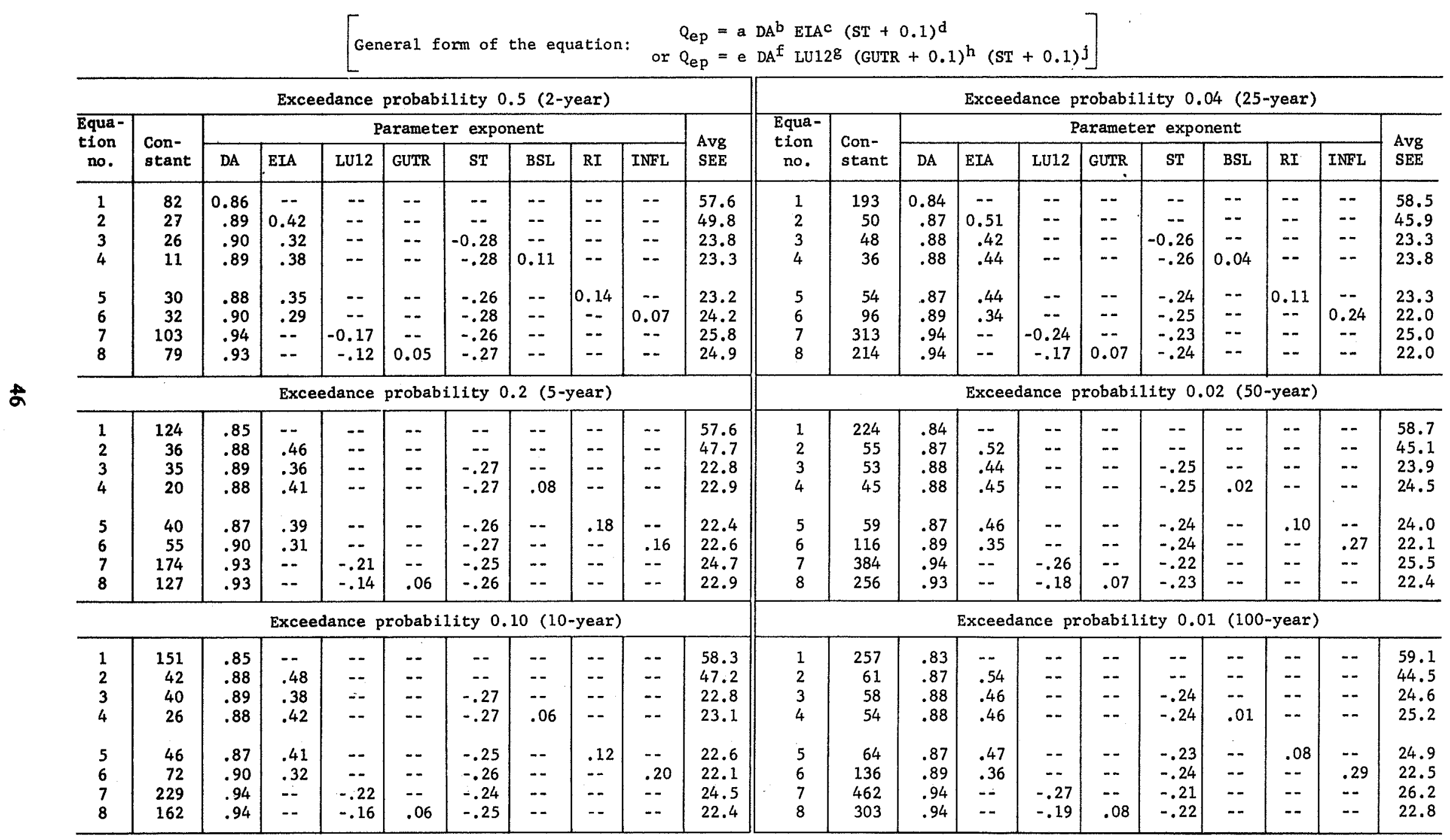


Table 9.--Sumary of statistics for regression analysis of storm runoff without base flow for selected exceedance probabilities (recurrence intervals)

\begin{tabular}{|c|c|c|c|c|c|c|c|c|c|c|c|c|c|c|c|c|c|}
\hline \multirow{3}{*}{$\begin{array}{c}\text { Equa- } \\
\text { tion } \\
\text { no. }\end{array}$} & \multicolumn{8}{|c|}{ Exceedance probability 0.5 (2-year) } & \multicolumn{9}{|c|}{ Exceedance probability 0.04 (25-year) } \\
\hline & \multicolumn{6}{|c|}{ Parameter "F" value } & \multirow{2}{*}{$\begin{array}{c}\mathrm{R}- \\
\text { square }\end{array}$} & \multirow{2}{*}{$\begin{array}{l}\text { Avg } \\
\text { SEE }\end{array}$} & \multirow{2}{*}{$\begin{array}{l}\text { Equa- } \\
\text { tion } \\
\text { no. }\end{array}$} & \multicolumn{6}{|c|}{ Parameter "F" value } & \multirow{2}{*}{$\begin{array}{c}R- \\
\text { square }\end{array}$} & \multirow{2}{*}{$\begin{array}{l}\text { Avg } \\
\text { SEE }\end{array}$} \\
\hline & RI & BSL & EIA & LU12 & GUTR $1 /$ & $\mathrm{ST}=1 /$ & & & & RI & BSL & EIA & LU12 & GUTR $1 /$ & $\mathrm{ST}$ 는 & & \\
\hline $\begin{array}{l}1 \\
2 \\
3 \\
4 \\
5 \\
6\end{array}$ & $\begin{array}{l}16.2 \\
19.8 \\
26.2 \\
21.7 \\
20.0 \\
19.5\end{array}$ & $\begin{array}{r}-- \\
6.1 \\
10.7 \\
10.2 \\
5.8 \\
5.9\end{array}$ & $\begin{array}{l}-- \\
-- \\
3.8 \\
3.2 \\
-- \\
--\end{array}$ & $\begin{array}{l}-- \\
-- \\
-- \\
-- \\
0.60 \\
.28\end{array}$ & $\begin{array}{l}-- \\
-- \\
-- \\
-- \\
-- \\
0.41\end{array}$ & $\begin{array}{c}- \\
- \\
\cdots \\
0.13 \\
- \\
--\end{array}$ & $\begin{array}{r}0.424 \\
.554 \\
.626 \\
.628 \\
.568 \\
.577\end{array}$ & \begin{tabular}{|l}
43.2 \\
38.7 \\
36.2 \\
37.1 \\
39.1 \\
39.7
\end{tabular} & $\begin{array}{l}1 \\
2 \\
3 \\
4 \\
5 \\
6\end{array}$ & $\begin{array}{l}14.6 \\
19.0 \\
27.2 \\
21.9 \\
24.7 \\
21.6\end{array}$ & \begin{tabular}{r}
\multicolumn{1}{c}{-} \\
7.9 \\
14.2 \\
13.6 \\
12.5 \\
9.5
\end{tabular} & $\begin{array}{l}-- \\
-- \\
4.9 \\
3.9 \\
-- \\
--\end{array}$ & $\begin{array}{l}-- \\
-- \\
-- \\
-- \\
3.7 \\
3.3\end{array}$ & $\begin{array}{l}- \\
- \\
- \\
-- \\
-- \\
0.01\end{array}$ & $\begin{array}{c}-- \\
-- \\
-- \\
0.46 \\
-- \\
--\end{array}$ & $\begin{array}{r}0.399 \\
.564 \\
.649 \\
.657 \\
.632 \\
.632\end{array}$ & $\begin{array}{l}36.5 \\
31.7 \\
29.0 \\
29.4 \\
29.8 \\
30.5\end{array}$ \\
\hline \multicolumn{9}{|c|}{ Exceedance probability 0.2 (5-year) } & \multicolumn{9}{|c|}{ Exceedance probability 0.02 (50-year) } \\
\hline $\begin{array}{l}1 \\
2 \\
3 \\
4 \\
5 \\
6\end{array}$ & $\begin{array}{l}12.9 \\
17.0 \\
23.9 \\
19.3 \\
20.4 \\
18.6\end{array}$ & \begin{tabular}{r}
\multicolumn{1}{c}{} \\
8.2 \\
13.8 \\
13.2 \\
10.8 \\
9.1
\end{tabular} & $\begin{array}{l}-- \\
-- \\
4.4 \\
3.5 \\
-- \\
--\end{array}$ & $\begin{array}{c}-- \\
-- \\
-- \\
-- \\
2.42 \\
1.89\end{array}$ & $\begin{array}{l}-- \\
-- \\
-- \\
-- \\
.05\end{array}$ & $\begin{array}{l}- \\
\cdots \\
-- \\
.37 \\
\therefore-\end{array}$ & $\begin{array}{l}.370 \\
.547 \\
.628 \\
.636 \\
.596 \\
.597\end{array}$ & \begin{tabular}{|l}
39.8 \\
34.3 \\
31.8 \\
32.3 \\
33.2 \\
34.0
\end{tabular} & $\begin{array}{l}1 \\
2 \\
3 \\
4 \\
5 \\
6\end{array}$ & $\begin{array}{l}15.3 \\
19.6 \\
28.0 \\
22.6 \\
26.1 \\
22.6\end{array}$ & \begin{tabular}{r}
\multicolumn{1}{|c}{-} \\
7.5 \\
13.8 \\
13.2 \\
12.7 \\
9.3
\end{tabular} & $\begin{array}{l}-- \\
-- \\
4.9 \\
3.9 \\
-- \\
--\end{array}$ & $\begin{array}{l}=- \\
=- \\
=- \\
4.2 \\
3.9\end{array}$ & $\begin{array}{l}\cdots \\
\cdots \\
\cdots \\
-- \\
.06\end{array}$ & $\begin{array}{l}-- \\
-- \\
-4 \\
.41 \\
--\end{array}$ & $\begin{array}{l}.410 \\
.565 \\
.651 \\
.658 \\
.640 \\
.641\end{array}$ & $\begin{array}{l}35.4 \\
31.0 \\
28.4 \\
28.8 \\
28.9 \\
29.6\end{array}$ \\
\hline \multicolumn{9}{|c|}{ Exceedance probability 0.10 (10-year) } & \multicolumn{9}{|c|}{ Exceedance probability 0.01 (100-year) } \\
\hline $\begin{array}{l}1 \\
2 \\
3 \\
4 \\
5 \\
6\end{array}$ & $\begin{array}{l}13.7 \\
18.0 \\
25.6 \\
20.6 \\
22.4 \\
20.1\end{array}$ & $\begin{array}{r}-- \\
8.2 \\
14.2 \\
13.6 \\
11.8 \\
9.4\end{array}$ & $\begin{array}{l}-. \\
-- \\
4.6 \\
3.7 \\
-- \\
--\end{array}$ & $\begin{array}{c}-- \\
-- \\
-- \\
-. \\
3.0 \\
2.5\end{array}$ & $\begin{array}{l}-- \\
-- \\
-- \\
-- \\
-- \\
.01\end{array}$ & $\begin{array}{l}-- \\
- \\
-. \\
.46 \\
-- \\
--\end{array}$ & $\begin{array}{l}.384 \\
.557 \\
.641 \\
.649 \\
.615 \\
.615\end{array}$ & $\begin{array}{l}38.4 \\
33.1 \\
30.5 \\
30.9 \\
31.6 \\
32.4\end{array}$ & $\begin{array}{l}1 \\
2 \\
3 \\
4 \\
5 \\
6\end{array}$ & $\begin{array}{l}15.7 \\
19.7 \\
28.5 \\
23.1 \\
27.2 \\
23.4\end{array}$ & $\begin{array}{r}-- \\
6.8 \\
13.3 \\
12.7 \\
12.8 \\
9.2\end{array}$ & $\begin{array}{l}-- \\
-- \\
5.2 \\
4.2 \\
-- \\
--\end{array}$ & $\begin{array}{l}-- \\
-- \\
-- \\
-- \\
4.8 \\
4.6\end{array}$ & $\begin{array}{l}\ldots \\
-- \\
-- \\
-- \\
.14\end{array}$ & $\begin{array}{l}-- \\
-- \\
-38 \\
.- \\
--\end{array}$ & $\begin{array}{l}.417 \\
.560 \\
.650 \\
.657 \\
.645 \\
.648\end{array}$ & $\begin{array}{l}34.6 \\
30.7 \\
28.0 \\
28.4 \\
28.2 \\
28.8\end{array}$ \\
\hline
\end{tabular}

1/ Outside of 95 percent significance level. 
Table 10.--Sumary of regression-equation coefficients and exponents for storm runoff without base flow for selected exceedance probabilities (recurrence intervals)

General form of the equation: $\left.\begin{array}{rl}R_{e p} & =a(R I-1.7)^{b} B^{3} L^{c} \text { EIA } d \\ \text { or } R_{e p} & =e(R I-1.7)^{f} \text { BSLG LUI2 }\end{array}\right]$

\begin{tabular}{|c|c|c|c|c|c|c|c|c|c|c|c|c|c|c|c|c|c|}
\hline \multicolumn{9}{|c|}{ Exceedance probability 0.5 (2-year) } & \multicolumn{9}{|c|}{ Exceedance probability 0.04 (25-year) } \\
\hline \multirow{2}{*}{$\begin{array}{c}\text { Equa- } \\
\text { tion } \\
\text { no. }\end{array}$} & \multirow{2}{*}{$\begin{array}{l}\text { Con- } \\
\text { stant }\end{array}$} & \multicolumn{6}{|c|}{ Parameter exponent } & \multirow{2}{*}{$\begin{array}{l}\text { Avg } \\
\text { SEE }\end{array}$} & \multirow{2}{*}{$\begin{array}{c}\text { Equa- } \\
\text { tion } \\
\text { no. }\end{array}$} & \multirow{2}{*}{$\begin{array}{l}\text { Con- } \\
\text { stant }\end{array}$} & \multicolumn{6}{|c|}{ Parameter exponent } & \multirow{2}{*}{$\begin{array}{l}\text { Avg } \\
\text { SEE }\end{array}$} \\
\hline & & RI & BSL & EIA & LU12 & GUTR & ST & & & & RI & BSL & EIA & LU12 & GUTR & ST & \\
\hline 1 & & 0.67 & -- & -- & -- & -- & -- & 43.2 & 1 & 5.3 & 0.54 & $\ldots$ & -. & -- & $=$ & & 6.5 \\
\hline 2 & .44 & .67 & 0.27 & -- & -- & - & -- & & 2 & 1. & .54 & 0.25 & -. & -- & -. & -- & 31.7 \\
\hline 3 & .096 & .76 & .43 & 0.28 & -. & -- & -. & 36.2 & 3 & .30 & .63 & .40 & 0.26 & -- & -- & -- & 29.0 \\
\hline 4 & .096 & .75 & .43 & .27 & -- & -- & -0.02 & 37.1 & 4 & .30 & .60 & .40 & .24 & -- & -- & -0.03 & 29.4 \\
\hline 5 & .39 & .70 & .34 & -- & -0.07 & -. & -. & 39.1 & 5 & .96 & .60 & .38 & -. & -0.13 & -- & -- & 29.8 \\
\hline 6 & .28 & .72 & .38 & -- & -.05 & 0.04 & -- & 39.7 & 6 & .99 & .59 & .37 & -- & -.13 & -0.004 & -- & 30.5 \\
\hline \multicolumn{9}{|c|}{ Exceedance probability 0.2 (5-year) } & \multicolumn{9}{|c|}{ Exceedance probability 0.02 (50-year) } \\
\hline 1 & 3.0 & .55 & -- & -- & -- & -- & -- & 39.8 & 1 & 6.4 & .54 & -- & -- & -- & - & -- & 35.4 \\
\hline 2 & .60 & .55 & .28 & -- & -- & -- & -- & 34 . & 2 & 1.55 & .54 & .24 & -- & -- & -- & -- & 31.0 \\
\hline 3 & .14 & .64 & .43 & .27 & -- & -- & -- & 31. & 3 & .40 & .6 & .38 & .26 & -- & -- & -- & 28.4 \\
\hline 4 & .14 & .62 & .43 & .25 & -- & -- & -.03 & 32. & 4 & .39 & .60 & .38 & .24 & -- & -- & -.03 & \\
\hline 5 & .48 & .60 & .39 & -- & -.11 & -- & -- & 33.2 & 5 & 1.22 & .60 & .37 & -- & -.13 & -- & -- & 28.9 \\
\hline 6 & .43 & .61 & .41 & -- & -.11 & .01 & -- & 34.0 & 6 & 1.34 & .59 & .36 & -- & -.14 & -.01 & -- & 29.6 \\
\hline \multicolumn{9}{|c|}{ Exceedance probability 0.10 (10-year) } & \multicolumn{9}{|c|}{ Exceedance probability 0.01 (100-year) } \\
\hline 1 & 4.0 & .55 & -- & -. & $\cdots$ & -. & $\cdots$ & 38. & 1 & 7. & & -- & - & -- & -- & -- & 34.6 \\
\hline 2 & .83 & .55 & .27 & -- & -- & -. & -- & & 2 & 1.97 & .53 & .23 & .- & -- & -- & -- & 30.7 \\
\hline 3 & .20 & .64 & .42 & .27 & -- & -- & -- & 30. & 3 & .5 & .6 & .37 & .26 & -- & -- & 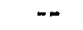 & \\
\hline 4 & .20 & .61 & .42 & .25 & -- & -- & -.03 & 30. & 4 & .49 & .60 & .37 & .24 & -. & -- & -.03 & 28.4 \\
\hline 5 & .66 & .60 & .39 & -- & -.12 & -- & -- & 31. & 5 & 1.52 & .59 & .36 & -- & -.14 & -- & -- & 28.2 \\
\hline 6 & .64 & .61 & .40 & -- & -.12 & .004 & -- & 32.4 & 6 & 1.75 & .58 & .35 & -- & -.14 & -.02 & -- & 28.8 \\
\hline
\end{tabular}


Table 11.--Summary of statistics for regression analysis of storm runoff with base flow for selected exceedance probabilities (recurrence intervals)

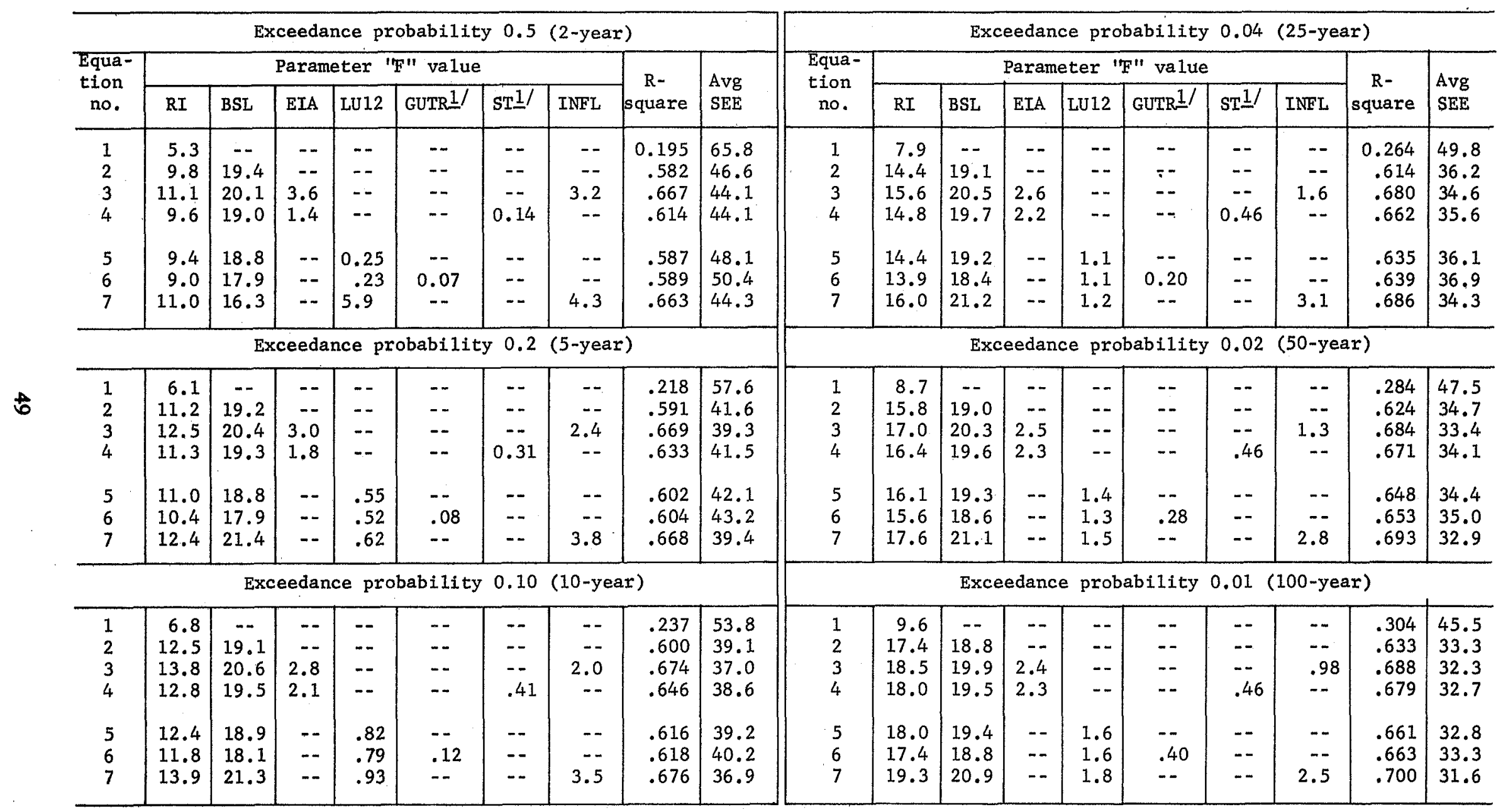

1/ Outside of 95 percent significance level. 
Table 12.--Summary of regression-equation coefficients and exponents for storm runoff with base flow for selected exceedance probabilities (recurrence intervals)

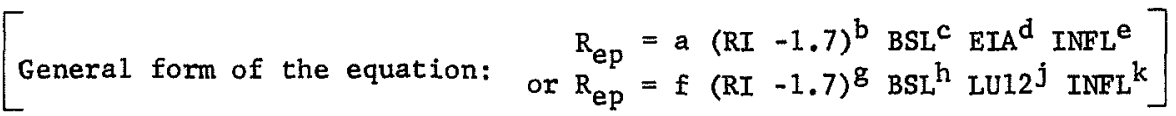

\begin{tabular}{|c|c|c|c|c|c|c|c|c|c|c|c|c|c|c|c|c|c|c|c|}
\hline \multicolumn{10}{|c|}{ Exceedance probability 0.5 (2-year) } & \multicolumn{10}{|c|}{ Exceedance probability 0.04 (25-year) } \\
\hline \multirow{2}{*}{$\begin{array}{l}\text { Equa- } \\
\text { tion } \\
\text { no. }\end{array}$} & \multirow{2}{*}{$\begin{array}{l}\text { Con- } \\
\text { stant }\end{array}$} & \multicolumn{7}{|c|}{ Parameter exponent } & \multirow{2}{*}{$\begin{array}{l}\text { Avg } \\
\text { SEE }\end{array}$} & \multirow{2}{*}{$\begin{array}{c}\text { Equa- } \\
\text { tion } \\
\text { no. }\end{array}$} & \multirow{2}{*}{$\begin{array}{l}\text { Con- } \\
\text { stant }\end{array}$} & \multicolumn{7}{|c|}{ Parametèr exponent } & \multirow{2}{*}{$\begin{array}{l}\text { Avg } \\
\text { SEE }\end{array}$} \\
\hline & & RI & BSL & EIA & LU12 & GUTR & ST & INFL & & & & RI & BSL & EIA & LU12 & GUTR & ST & INFL & \\
\hline $\begin{array}{l}1 \\
2 \\
3 \\
4 \\
\\
5 \\
6 \\
7\end{array}$ & $\begin{array}{l}3.0 \\
.10 \\
.025 \\
.030 \\
.093 \\
.11 \\
.078\end{array}$ & $\begin{array}{r}0.56 \\
.56 \\
.55 \\
.61 \\
\\
.58 \\
.57 \\
.49\end{array}$ & $\begin{array}{c}-. \\
0.58 \\
.50 \\
.70 \\
\\
.63 \\
.61 \\
.44\end{array}$ & $\begin{array}{c}-- \\
-- \\
0.26 \\
.21 \\
-- \\
-- \\
--\end{array}$ & $\begin{array}{r}-- \\
-- \\
-- \\
-- \\
-0.05 \\
-.06 \\
-.15\end{array}$ & $\begin{array}{c}-- \\
-- \\
-- \\
-- \\
-- \\
-0.02 \\
--\end{array}$ & $\begin{array}{c}-- \\
-- \\
- \\
-0.03 \\
- \\
-- \\
--\end{array}$ & $\begin{array}{c}- \\
-- \\
-0.56 \\
-- \\
-- \\
- \\
-.72\end{array}$ & $\begin{array}{l}65.8 \\
46.6 \\
44.1 \\
44.1 \\
48.1 \\
50.4 \\
44.3\end{array}$ & $\begin{array}{l}1 \\
2 \\
3 \\
4 \\
\\
5 \\
6 \\
7\end{array}$ & $\begin{array}{c}7.3 \\
.54 \\
.16 \\
.17 \\
\\
.46 \\
.57 \\
.41\end{array}$ & $\begin{array}{l}0.54 \\
.53 \\
.55 \\
.57 \\
\\
.57 \\
.55 \\
.51\end{array}$ & $\begin{array}{r}-. \\
0.45 \\
.45 \\
.56 \\
\\
.53 \\
.51 \\
.40\end{array}$ & $\begin{array}{c}-- \\
-- \\
0.23 \\
.19 \\
-- \\
-- \\
--\end{array}$ & $\begin{array}{r}-- \\
-- \\
-- \\
-- \\
-0.08 \\
-.10 \\
-.15\end{array}$ & $\begin{array}{c}-- \\
-- \\
-- \\
-- \\
- \\
-0.03 \\
--\end{array}$ & $\begin{array}{c}-- \\
-- \\
-0.04 \\
-- \\
-- \\
--\end{array}$ & $\begin{array}{c}-- \\
- \\
-0.31 \\
-- \\
-- \\
-. \\
-.49\end{array}$ & $\begin{array}{l}49.8 \\
36.2 \\
34.6 \\
35.6 \\
\\
36.1 \\
36.9 \\
34.3\end{array}$ \\
\hline \multicolumn{10}{|c|}{ Exceedance probability 0.2 (5-year) } & \multicolumn{10}{|c|}{ Exceedance probability 0.02 (50-year) } \\
\hline $\begin{array}{l}1 \\
2 \\
3 \\
4 \\
\\
5 \\
6 \\
7\end{array}$ & $\begin{array}{l}4.6 \\
.23 \\
.060 \\
.068 \\
\\
.20 \\
.24 \\
.17\end{array}$ & $\begin{array}{l}.54 \\
.53 \\
.54 \\
.58 \\
\\
.56 \\
.55 \\
.49\end{array}$ & $\begin{array}{l}-. \\
.51 \\
.48 \\
.64 \\
\\
.58 \\
.56 \\
.42\end{array}$ & $\begin{array}{l}-- \\
-- \\
.25 \\
.20 \\
-- \\
-- \\
--\end{array}$ & $\begin{array}{c}-- \\
-- \\
-- \\
-- \\
-.07 \\
-.08 \\
-.015\end{array}$ & $\begin{array}{c}-- \\
-- \\
-- \\
-- \\
-- \\
-.02 \\
--\end{array}$ & $\begin{array}{l}-- \\
-- \\
-- \\
-.03 \\
-- \\
-- \\
--\end{array}$ & $\begin{array}{c}- \\
\cdots \\
-.44 \\
-- \\
-- \\
-- \\
-.61\end{array}$ & $\begin{array}{l}57.6 \\
41.6 \\
39.3 \\
41.5 \\
42.1 \\
43.2 \\
39.4\end{array}$ & $\begin{array}{l}1 \\
2 \\
3 \\
4 \\
\\
5 \\
6 \\
7\end{array}$ & $\begin{array}{c}8.6 \\
.71 \\
.21 \\
.23 \\
\\
.60 \\
.76 \\
.54\end{array}$ & $\begin{array}{l}.54 \\
.53 \\
.56 \\
.57 \\
\\
.57 \\
.55 \\
.52\end{array}$ & $\begin{array}{l}-. \\
.43 \\
.44 \\
.54 \\
\\
.52 \\
.49 \\
.40\end{array}$ & $\begin{array}{l}-- \\
-- \\
.23 \\
.18 \\
-- \\
-- \\
--\end{array}$ & $\begin{array}{c}-- \\
-- \\
-- \\
-- \\
-.09 \\
-.10 \\
-.15\end{array}$ & $\begin{array}{l}-- \\
-- \\
-- \\
-- \\
- \\
-.03 \\
--\end{array}$ & $\begin{array}{l}-- \\
-- \\
-- \\
-.03 \\
-- \\
-- \\
--\end{array}$ & $\begin{array}{l}-- \\
-- \\
-.27 \\
-- \\
-- \\
-- \\
-.44\end{array}$ & $\begin{array}{l}47.5 \\
34.7 \\
33.4 \\
34.1 \\
34.4 \\
35.0 \\
32.9\end{array}$ \\
\hline \multicolumn{10}{|c|}{ Exceedance probability 0.10 (10-year) } & \multicolumn{10}{|c|}{ Exceedance probability 0.01 (100-year) } \\
\hline $\begin{array}{l}1 \\
2 \\
3 \\
4\end{array}$ & $\begin{array}{l}5.7 \\
.35 \\
.092 \\
.10\end{array}$ & $\begin{array}{l}.53 \\
.53 \\
.54 \\
.57\end{array}$ & $\begin{array}{l}.- \\
.48 \\
.47 \\
.60\end{array}$ & $\begin{array}{l}-- \\
-- \\
.25 \\
.20\end{array}$ & $\begin{array}{l}-- \\
-- \\
-- \\
--\end{array}$ & $\begin{array}{l}-- \\
-- \\
-- \\
--\end{array}$ & $\begin{array}{c}- \\
-- \\
-- \\
-.04\end{array}$ & $\begin{array}{c}-- \\
-- \\
-.38 \\
--\end{array}$ & $\begin{array}{l}53.8 \\
39.1 \\
37.0 \\
38.6\end{array}$ & $\begin{array}{l}1 \\
2 \\
3 \\
4\end{array}$ & $\begin{array}{r}10 \\
.92 \\
.29 \\
.31\end{array}$ & $\begin{array}{l}.54 \\
.54 \\
.57 \\
.57\end{array}$ & $\begin{array}{l}. .41 \\
.44 \\
.52\end{array}$ & $\begin{array}{l}-- \\
-- \\
.22 \\
.18\end{array}$ & $\begin{array}{l}-- \\
-- \\
-- \\
--\end{array}$ & $\begin{array}{l}-- \\
-- \\
-- \\
--\end{array}$ & $\begin{array}{c}-- \\
- \\
-- \\
-.03\end{array}$ & $\begin{array}{c}-- \\
-- \\
-.23 \\
--\end{array}$ & $\begin{array}{l}45.5 \\
33.3 \\
32.3 \\
32.7\end{array}$ \\
\hline $\begin{array}{l}5 \\
6 \\
7\end{array}$ & $\begin{array}{l}.30 \\
.36 \\
.26\end{array}$ & $\begin{array}{l}.56 \\
.55 \\
.50\end{array}$ & $\begin{array}{l}.56 \\
.54 \\
.41\end{array}$ & $\begin{array}{l}-- \\
-- \\
--\end{array}$ & $\begin{array}{l}-.08 \\
-.09 \\
-.16\end{array}$ & $\begin{array}{c}-- \\
-.02 \\
--\end{array}$ & $\begin{array}{l}-- \\
--\end{array}$ & $\begin{array}{c}-- \\
-- \\
-.55\end{array}$ & $\begin{array}{l}39.2 \\
40.2 \\
36.9\end{array}$ & $\begin{array}{l}5 \\
6 \\
7\end{array}$ & $\begin{array}{l}.77 \\
1.0 \\
.69\end{array}$ & $\begin{array}{l}.58 \\
.56 \\
.53\end{array}$ & $\begin{array}{l}.50 \\
.47 \\
.40\end{array}$ & $\begin{array}{l}-- \\
-- \\
--\end{array}$ & $\begin{array}{l}-.09 \\
-.11 \\
-.15\end{array}$ & $\begin{array}{c}-- \\
-.03 \\
--\end{array}$ & $\begin{array}{l}-- \\
--\end{array}$ & $\begin{array}{c}-- \\
-. \\
-.40\end{array}$ & $\begin{array}{l}32.8 \\
33.3 \\
31.6\end{array}$ \\
\hline
\end{tabular}


TABLE 13.-DAILY PRECIPITATION

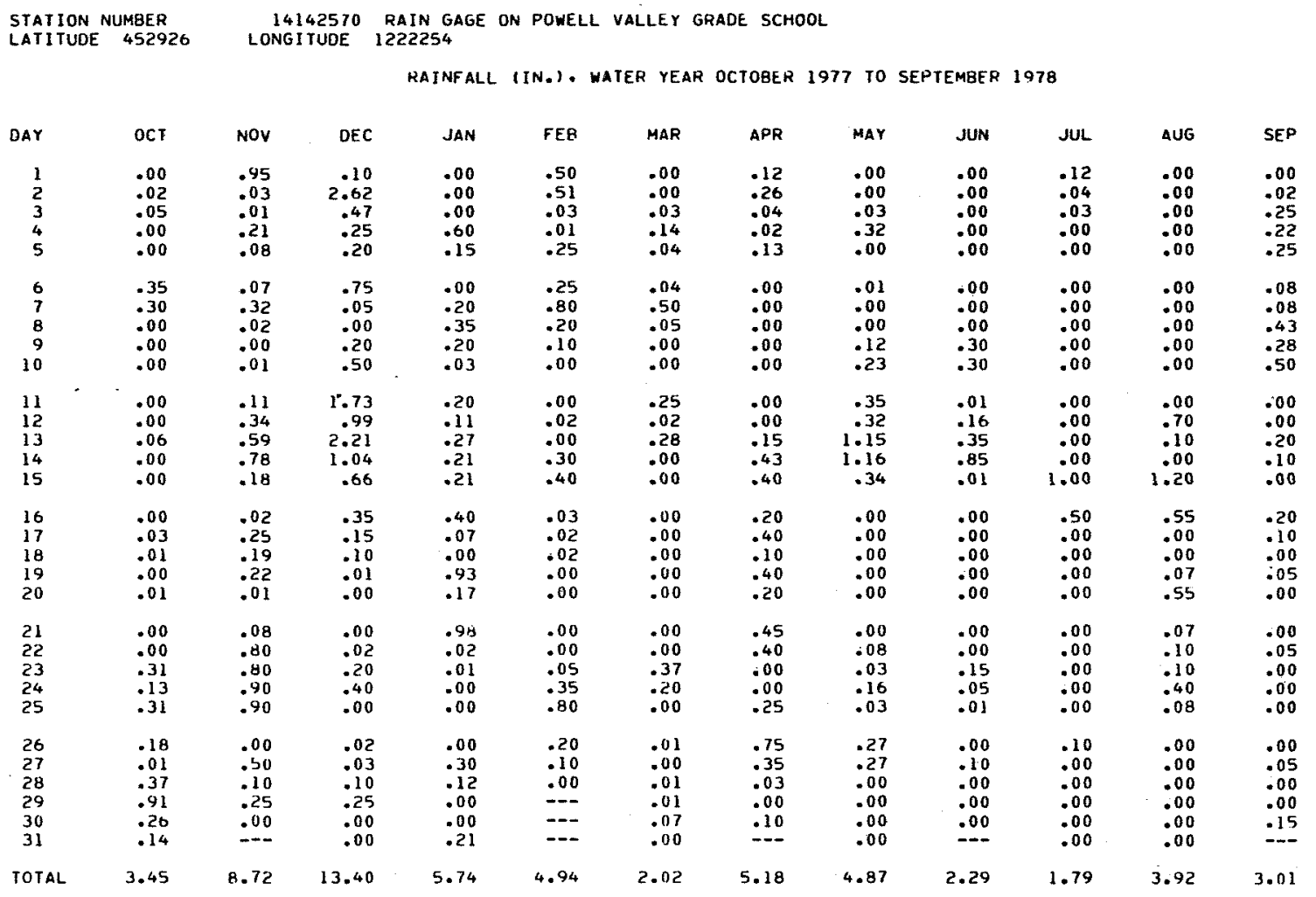

WTR YR 1978 TOTAL 59.33

STATION NUMBER 14144680 RAIN GAGE ON VANCOUVER CITY HALL

LATITUDE 453754 LONGITUDE 1224008

RAINFALL (IN.), WAIEK YEAR OCTUBEM IY77 TO SEPTEMBER 1У78

\begin{tabular}{|c|c|c|c|c|c|c|c|c|c|c|c|c|}
\hline DAY & $O C T$ & NUV & DEC & JAN & FEG & $M A R$ & APK & MAY & JUN & JUL & $\triangle \cup U$ & Sip \\
\hline $\begin{array}{l}1 \\
2 \\
3 \\
4 \\
5\end{array}$ & $\begin{array}{l}.01 \\
.00 \\
.00 \\
.00 \\
.00\end{array}$ & $\begin{array}{l}.36 \\
.01 \\
.00 \\
.09 \\
.15\end{array}$ & $\begin{array}{r}.00 \\
1.37 \\
.12 \\
.00 \\
.17\end{array}$ & $\begin{array}{l}.13 \\
.10 \\
.08 \\
.35 \\
.41\end{array}$ & $\begin{array}{l}.45 \\
.27 \\
.00 \\
.00 \\
.23\end{array}$ & $\begin{array}{l}.00 \\
.00 \\
.04 \\
.06 \\
.00\end{array}$ & $\begin{array}{l}.01 \\
.02 \\
.02 \\
.15 \\
.18\end{array}$ & $\begin{array}{l}.01 \\
.00 \\
.00 \\
.14 \\
.00\end{array}$ & $\begin{array}{l}.00 \\
.00 \\
.00 \\
.00 \\
.00\end{array}$ & $\begin{array}{l}.00 \\
.15 \\
.02 \\
.00 \\
.01\end{array}$ & $\begin{array}{l}.00 \\
.00 \\
.00 \\
.00 \\
.00\end{array}$ & $\begin{array}{l}.00 \\
.00 \\
.>0 \\
.05 \\
.01\end{array}$ \\
\hline $\begin{array}{r}6 \\
7 \\
8 \\
9 \\
10\end{array}$ & $\begin{array}{l}.19 \\
.43 \\
.00 \\
.00 \\
.00\end{array}$ & $\begin{array}{l}.06 \\
.11 \\
.00 \\
.02 \\
.07\end{array}$ & $\begin{array}{l}.14 \\
.03 \\
.00 \\
.12 \\
.51\end{array}$ & $\begin{array}{l}.00 \\
.19 \\
.34 \\
.30 \\
.00\end{array}$ & $\begin{array}{l}.10 \\
.51 \\
.08 \\
.00 \\
.00\end{array}$ & $\begin{array}{l}.10 \\
.48 \\
.00 \\
.00 \\
.00\end{array}$ & $\begin{array}{l}.03 \\
.00 \\
.00 \\
.00 \\
.00\end{array}$ & $\begin{array}{l}.00 \\
.00 \\
.00 \\
.00 \\
.00\end{array}$ & $\begin{array}{l}.00 \\
.00 \\
.00 \\
.11 \\
.10\end{array}$ & $\begin{array}{l}.00 \\
.00 \\
.00 \\
.00 \\
.00\end{array}$ & $\begin{array}{l}.00 \\
.00 \\
.00 \\
.00 \\
.00\end{array}$ & $\begin{array}{l}.00 \\
.02 \\
.35 \\
.49 \\
.12\end{array}$ \\
\hline $\begin{array}{l}11 \\
12 \\
13 \\
14 \\
15\end{array}$ & $\begin{array}{l}.00 \\
.00 \\
.00 \\
.00 \\
.00\end{array}$ & $\begin{array}{l}.03 \\
.35 \\
.15 \\
.14 \\
.11\end{array}$ & $\begin{array}{r}.40 \\
.79 \\
1.62 \\
.51 \\
.85\end{array}$ & $\begin{array}{l}.08 \\
.00 \\
.25 \\
.08 \\
.12\end{array}$ & $\begin{array}{l}.00 \\
.00 \\
.00 \\
.10 \\
.04\end{array}$ & $\begin{array}{l}.10 \\
.03 \\
.04 \\
.00 \\
.00\end{array}$ & $\begin{array}{l}.00 \\
.00 \\
.26 \\
.15 \\
.33\end{array}$ & $\begin{array}{r}.22 \\
.30 \\
1.17 \\
.67 \\
.07\end{array}$ & $\begin{array}{l}.01 \\
.01 \\
.10 \\
.30 \\
.01\end{array}$ & $\begin{array}{l}.00 \\
.00 \\
.00 \\
.00 \\
.81\end{array}$ & $\begin{array}{l}.01 \\
.21 \\
.07 \\
.00 \\
.66\end{array}$ & $\begin{array}{l}.111 \\
.00 \\
.20 \\
.04 \\
.00\end{array}$ \\
\hline $\begin{array}{l}16 \\
17 \\
18 \\
19 \\
20\end{array}$ & $\begin{array}{l}.00 \\
.00 \\
.00 \\
.00 \\
.00\end{array}$ & $\begin{array}{l}.11 \\
.06 \\
.03 \\
.02 \\
.10\end{array}$ & $\begin{array}{l}.26 \\
.04 \\
.00 \\
.00 \\
.00\end{array}$ & $\begin{array}{l}.19 \\
.19 \\
.32 \\
.05 \\
.00\end{array}$ & $\begin{array}{l}.02 \\
.02 \\
.00 \\
.00 \\
.00\end{array}$ & $\begin{array}{l}.00 \\
.00 \\
.00 \\
.00 \\
.00\end{array}$ & $\begin{array}{r}.29 \\
.33 \\
.30 \\
.24 \\
.03\end{array}$ & $\begin{array}{l}.00 \\
.01 \\
.00 \\
.00 \\
.00\end{array}$ & $\begin{array}{l}.00 \\
.00 \\
.00 \\
.00 \\
.00\end{array}$ & $\begin{array}{l}.44 \\
.00 \\
.00 \\
.00 \\
.00\end{array}$ & $\begin{array}{l}.11 \\
.01 \\
.00 \\
.05 \\
.38\end{array}$ & $\begin{array}{l}.01 \\
.16 \\
.01 \\
.00 \\
.08\end{array}$ \\
\hline $\begin{array}{l}21 \\
22 \\
23 \\
24 \\
25\end{array}$ & $\begin{array}{l}.00 \\
.00 \\
.07 \\
.27 \\
.30\end{array}$ & $\begin{array}{l}.14 \\
.35 \\
.36 \\
.35 \\
.87\end{array}$ & $\begin{array}{l}.00 \\
.00 \\
.21 \\
.11 \\
.00\end{array}$ & $\begin{array}{l}.27 \\
.00 \\
.00 \\
.00 \\
.12\end{array}$ & $\begin{array}{l}.00 \\
.00 \\
.02 \\
.25 \\
1.07\end{array}$ & $\begin{array}{l}.00 \\
.00 \\
.30 \\
.10 \\
.02\end{array}$ & $\begin{array}{l}.14 \\
.16 \\
.00 \\
.00 \\
.10\end{array}$ & $\begin{array}{l}.00 \\
.10 \\
.01 \\
.18 \\
.01\end{array}$ & $\begin{array}{l}.00 \\
.00 \\
.14 \\
.00 \\
.00\end{array}$ & $\begin{array}{l}.00 \\
.00 \\
.00 \\
.00 \\
.00\end{array}$ & $\begin{array}{l}.08 \\
.07 \\
.14 \\
.16 \\
.00\end{array}$ & $\begin{array}{l}.01 \\
.00 \\
.00 \\
.00 \\
.00\end{array}$ \\
\hline $\begin{array}{l}26 \\
27 \\
28 \\
29 \\
30 \\
31\end{array}$ & $\begin{array}{l}.00 \\
.00 \\
.22 \\
.38 \\
.21 \\
.04\end{array}$ & $\begin{array}{l}.00 \\
.11 \\
.13 \\
.03 \\
.00 \\
-\cdots\end{array}$ & $\begin{array}{l}.00 \\
.00 \\
.14 \\
.29 \\
.11 \\
.00\end{array}$ & $\begin{array}{l}.00 \\
.00 \\
.05 \\
.00 \\
.00 \\
.51\end{array}$ & \begin{tabular}{l}
.07 \\
.00 \\
.00 \\
\hdashline-0 \\
-0
\end{tabular} & $\begin{array}{l}.00 \\
.00 \\
.00 \\
.00 \\
.03 \\
.00\end{array}$ & $\begin{array}{l}.35 \\
.04 \\
.05 \\
.00 \\
.07 \\
-.\end{array}$ & $\begin{array}{l}.22 \\
.13 \\
.00 \\
000 \\
.00 \\
.00\end{array}$ & $\begin{array}{l}.01 \\
.00 \\
.00 \\
.00 \\
.00 \\
-0 .\end{array}$ & $\begin{array}{l}.04 \\
.00 \\
.00 \\
.00 \\
.00 \\
.00\end{array}$ & $\begin{array}{l}.00 \\
.00 \\
.00 \\
.00 \\
.00 \\
.00\end{array}$ & $\begin{array}{l}.00 \\
.00 \\
.00 \\
.00 \\
.10 \\
-.-\end{array}$ \\
\hline
\end{tabular}

$\begin{array}{llllllllllllll}\text { TOTAL } & 2.12 & 4.71 & 7.44 & 4.11 & .3 .31 & 1.31 & 3.34 & 3.36 & 0.87 & 1.47 & 1.96 & .0 .74\end{array}$

WTR YR 197H. TUTAL 30.48 


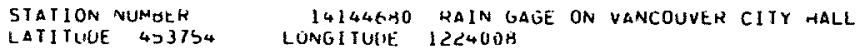

RAINFALL IIN.1. WATER VEAK OCTUBEK 1978 TO SEPTEMBER 1979

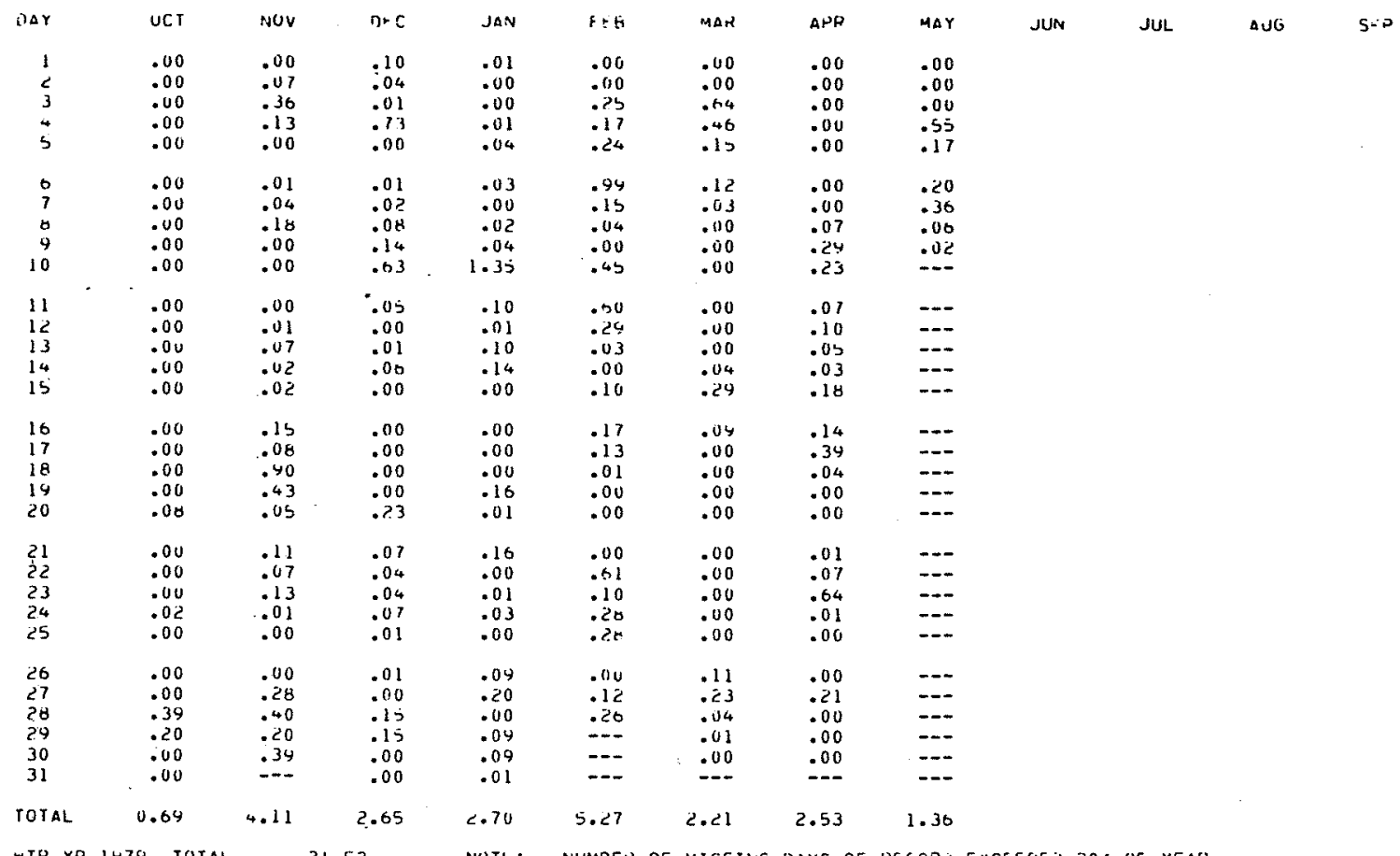

WTR YR 1479 TOTAL 21.52 NUTE: NUMBER OF MISSING DAYS OF RECORU EXCEEUEU 200 OF YEAR

STATION NUMBER
LATITUDE
452937

RAINFALL (IN,), WATER YEAR OCTOBER 1977 TO SEPTEMBER 1978

\begin{tabular}{|c|c|c|c|c|c|c|c|c|c|c|c|c|}
\hline DAY & OCT & NOV & DEC & JAN & FEB & MAK & APR & MAY & SUN & JUL & AUG & SE? \\
\hline $\begin{array}{l}1 \\
2 \\
3 \\
4 \\
5\end{array}$ & $\begin{array}{l}.00 \\
.00 \\
.00 \\
.00 \\
.00\end{array}$ & $\begin{array}{l}.37 \\
.10 \\
.01 \\
.09 \\
.15\end{array}$ & $\begin{array}{r}.05 \\
1.44 \\
.04 \\
.15 \\
.02\end{array}$ & $\begin{array}{l}.10 \\
.02 \\
.60 \\
.00 \\
.70\end{array}$ & $\begin{array}{l}.63 \\
.24 \\
.04 \\
.00 \\
.26\end{array}$ & $\begin{array}{l}.00 \\
.00 \\
.00 \\
.09 \\
.00\end{array}$ & $\begin{array}{l}.06 \\
.20 \\
.05 \\
.01 \\
.03\end{array}$ & $\begin{array}{l}.01 \\
.00 \\
.00 \\
.00 \\
.00\end{array}$ & $\begin{array}{l}.00 \\
.00 \\
.00 \\
.00 \\
.00\end{array}$ & $\begin{array}{l}.00 \\
.05 \\
.00 \\
.00 \\
.00\end{array}$ & $\begin{array}{l}.00 \\
.00 \\
.00 \\
.00 \\
.00\end{array}$ & $\begin{array}{l}.00 \\
.00 \\
.45 \\
.09 \\
.10\end{array}$ \\
\hline $\begin{array}{r}6 \\
7 \\
8 \\
9 \\
10\end{array}$ & $\begin{array}{l}.24 \\
.29 \\
.00 \\
.00 \\
.00\end{array}$ & $\begin{array}{l}.18 \\
.07 \\
.01 \\
.00 \\
.01\end{array}$ & $\begin{array}{l}.15 \\
.03 \\
.01 \\
.20 \\
.44\end{array}$ & $\begin{array}{l}.01 \\
.22 \\
.34 \\
.27 \\
.04\end{array}$ & $\begin{array}{r}.21 \\
.90 \\
.14 \\
.07 \\
.00\end{array}$ & $\begin{array}{l}.02 \\
.45 \\
.07 \\
.00 \\
.00\end{array}$ & $\begin{array}{l}.01 \\
.00 \\
.00 \\
.00 \\
.00\end{array}$ & $\begin{array}{l}.00 \\
.00 \\
.00 \\
.00 \\
.04\end{array}$ & $\begin{array}{l}.21 \\
.12 \\
.01 \\
.05 \\
.26\end{array}$ & $\begin{array}{l}.00 \\
.00 \\
.00 \\
.00 \\
.00\end{array}$ & $\begin{array}{l}.00 \\
.00 \\
.00 \\
.00 \\
.00\end{array}$ & $\begin{array}{l}.01 \\
.26 \\
.23 \\
.81 \\
.57\end{array}$ \\
\hline $\begin{array}{l}11 \\
12 \\
13 \\
14 \\
15\end{array}$ & $\begin{array}{l}.00 \\
.00 \\
.00 \\
.00 \\
.00\end{array}$ & $\begin{array}{l}.18 \\
.43 \\
.20 \\
.31 \\
.09\end{array}$ & $\begin{array}{r}.93 \\
.88 \\
1.96 \\
.77 \\
1.32\end{array}$ & $\begin{array}{l}.10 \\
.01 \\
.30 \\
.14 \\
.28\end{array}$ & $\begin{array}{l}.00 \\
.06 \\
.00 \\
.07 \\
.04\end{array}$ & $\begin{array}{l}.15 \\
.02 \\
.14 \\
.00 \\
.00\end{array}$ & $\begin{array}{l}.00 \\
.00 \\
.20 \\
.16 \\
.22\end{array}$ & $\begin{array}{r}.20 \\
.19 \\
1.25 \\
.82 \\
.50\end{array}$ & $\begin{array}{l}.30 \\
.01 \\
.08 \\
.16 \\
.00\end{array}$ & $\begin{array}{l}.00 \\
.00 \\
.00 \\
.00 \\
.46\end{array}$ & $\begin{array}{l}.00 \\
.27 \\
.07 \\
.00 \\
.70\end{array}$ & $\begin{array}{l}.06 \\
.01 \\
.18 \\
.01 \\
.00\end{array}$ \\
\hline $\begin{array}{l}16 \\
17 \\
18 \\
19 \\
20\end{array}$ & $\begin{array}{l}.00 \\
.00 \\
.00 \\
.00 \\
.00\end{array}$ & $\begin{array}{l}.02 \\
.25 \\
.17 \\
.00 \\
.08\end{array}$ & $\begin{array}{l}.40 \\
.02 \\
.03 \\
.00 \\
.00\end{array}$ & $\begin{array}{l}.26 \\
.24 \\
.42 \\
.03 \\
.04\end{array}$ & $\begin{array}{l}.04 \\
.01 \\
.00 \\
.00 \\
.00\end{array}$ & $\begin{array}{l}.00 \\
.00 \\
.00 \\
.00 \\
.00\end{array}$ & $\begin{array}{l}.03 \\
.26 \\
.20 \\
.15 \\
.06\end{array}$ & $\begin{array}{l}.00 \\
.00 \\
.01 \\
.00 \\
.00\end{array}$ & $\begin{array}{l}.00 \\
.00 \\
.00 \\
.00 \\
.00\end{array}$ & $\begin{array}{l}.13 \\
.00 \\
.00 \\
.00 \\
.00\end{array}$ & $\begin{array}{l}.00 \\
.01 \\
.00 \\
.02 \\
.59\end{array}$ & $\begin{array}{l}.10 \\
.37 \\
.01 \\
.00 \\
.05\end{array}$ \\
\hline $\begin{array}{l}21 \\
22 \\
23 \\
24 \\
25\end{array}$ & $\begin{array}{l}.00 \\
.00 \\
.11 \\
.49 \\
.48\end{array}$ & $\begin{array}{r}.08 \\
.50 \\
.35 \\
.55 \\
1.20\end{array}$ & $\begin{array}{l}.00 \\
.02 \\
.15 \\
.10 \\
.01\end{array}$ & $\begin{array}{l}.42 \\
.04 \\
.00 \\
.00 \\
.13\end{array}$ & $\begin{array}{l}.00 \\
.00 \\
.00 \\
.04 \\
.42\end{array}$ & $\begin{array}{l}.00 \\
.00 \\
.41 \\
.18 \\
.00\end{array}$ & $\begin{array}{l}.22 \\
.23 \\
.00 \\
.01 \\
.15\end{array}$ & $\begin{array}{l}.00 \\
.14 \\
.10 \\
.15 \\
.01\end{array}$ & $\begin{array}{l}.00 \\
.00 \\
.08 \\
.00 \\
.00\end{array}$ & $\begin{array}{l}.00 \\
.00 \\
.00 \\
.00 \\
.00\end{array}$ & $\begin{array}{l}.03 \\
.03 \\
.07 \\
.27 \\
.00\end{array}$ & $\begin{array}{l}.01 \\
.00 \\
.01 \\
.01 \\
.00\end{array}$ \\
\hline $\begin{array}{l}26 \\
27 \\
28 \\
29 \\
30 \\
.31\end{array}$ & $\begin{array}{l}.00 \\
.00 \\
.33 \\
.57 \\
.25 \\
.07\end{array}$ & $\begin{array}{l}.00 \\
110 \\
10 \\
115 \\
.00 \\
-\end{array}$ & $\begin{array}{l}.00 \\
.00 \\
.15 \\
.35 \\
.05 \\
.00\end{array}$ & $\begin{array}{l}.01 \\
.01 \\
.09 \\
.00 \\
.00 \\
.68\end{array}$ & \begin{tabular}{l}
.01 \\
000 \\
000 \\
\hdashline-0 \\
\hdashline-
\end{tabular} & $\begin{array}{l}.00 \\
.00 \\
.00 \\
.00 \\
.04 \\
.00\end{array}$ & $\begin{array}{l}.50 \\
.12 \\
.11 \\
.03 \\
.05 \\
-.-\end{array}$ & $\begin{array}{l}.26 \\
.18 \\
.00 \\
.00 \\
.00 \\
.00\end{array}$ & $\begin{array}{l}.00 \\
.00 \\
.00 \\
.00 \\
.00 \\
-\end{array}$ & $\begin{array}{l}.01 \\
.00 \\
.00 \\
.00 \\
.00 \\
.00\end{array}$ & $\begin{array}{l}.01 \\
.00 \\
.00 \\
.00 \\
.00 \\
.00\end{array}$ & $\begin{array}{l}.00 \\
.00 \\
.00 \\
.00 \\
.04 \\
-\end{array}$ \\
\hline TOTYAL & 2.83 & 5.73 & 9.67 & 5.50 & 3.18 & 1.57 & 3.12 & 3.86 & 1.28 & 0.70 & 2.13 & 3.43 \\
\hline
\end{tabular}


TABLE 13.-DAILY PRECIPITATION-Continued

STATION NUMBER 14206315 RAIN GAGE AT BEAVERTON CITY HALL

RAINFALL (IN.), WATER YEAK OCTOBEK 1977 TO SEPTEMBER 1978

\begin{tabular}{|c|c|c|c|c|c|c|c|c|c|c|c|c|}
\hline DAY & OCT & NOV & DEC & JAN & FEB & MAF & APK & MAY & JUN & JUL & AUG & SEP \\
\hline $\begin{array}{l}1 \\
2 \\
3 \\
4 \\
5\end{array}$ & $\begin{array}{l}.01 \\
.00 \\
.00 \\
.00 \\
.00\end{array}$ & $\begin{array}{l}.37 \\
.11 \\
.01 \\
.13 \\
.18\end{array}$ & $\begin{array}{r}.06 \\
1.44 \\
.05 \\
.15 \\
.02\end{array}$ & $\begin{array}{l}.12 \\
.03 \\
.65 \\
.00 \\
.70\end{array}$ & $\begin{array}{l}.62 \\
.22 \\
.00 \\
.00 \\
.25\end{array}$ & $\begin{array}{l}.00 \\
.00 \\
.08 \\
.10 \\
.00\end{array}$ & $\begin{array}{l}.07 \\
.21 \\
.06 \\
.17 \\
.32\end{array}$ & $\begin{array}{l}.00 \\
.00 \\
.00 \\
.05 \\
.00\end{array}$ & $\begin{array}{l}.00 \\
.00 \\
.00 \\
.00 \\
.00\end{array}$ & $\begin{array}{l}.00 \\
.06 \\
.00 \\
.00 \\
.00\end{array}$ & $\begin{array}{l}.00 \\
.00 \\
.00 \\
.00 \\
.00\end{array}$ & $\begin{array}{l}.01 \\
.01 \\
.46 \\
.10 \\
.11\end{array}$ \\
\hline $\begin{array}{r}6 \\
7 \\
8 \\
9 \\
10\end{array}$ & $\begin{array}{l}.19 \\
.33 \\
.00 \\
.00 \\
.00\end{array}$ & $\begin{array}{l}.13 \\
.06 \\
.00 \\
.01 \\
.01\end{array}$ & $\begin{array}{l}.14 \\
.03 \\
.01 \\
.18 \\
.44\end{array}$ & $\begin{array}{l}.01 \\
.30 \\
.34 \\
.31 \\
.01\end{array}$ & $\begin{array}{l}.22 \\
.75 \\
.22 \\
.06 \\
.00\end{array}$ & $\begin{array}{l}.04 \\
.50 \\
.06 \\
.00 \\
.00\end{array}$ & $\begin{array}{l}.00 \\
.00 \\
.00 \\
.00 \\
.00\end{array}$ & $\begin{array}{l}.00 \\
.00 \\
.00 \\
.02 \\
.10\end{array}$ & $\begin{array}{l}.00 \\
.00 \\
.00 \\
.19 \\
.11\end{array}$ & $\begin{array}{l}.00 \\
.00 \\
.00 \\
.00 \\
.00\end{array}$ & $\begin{array}{l}.00 \\
.00 \\
.00 \\
.00 \\
.00\end{array}$ & $\begin{array}{l}.01 \\
.21 \\
.25 \\
.84 \\
.49\end{array}$ \\
\hline $\begin{array}{l}11 \\
12 \\
13 \\
14 \\
15\end{array}$ & $\begin{array}{l}.00 \\
.00 \\
.02 \\
.00 \\
.00\end{array}$ & $\begin{array}{l}.16 \\
.33 \\
.23 \\
.32 \\
.07\end{array}$ & $\begin{array}{r}.93 \\
.88 \\
1.96 \\
.77 \\
1.32\end{array}$ & $\begin{array}{l}.10 \\
.00 \\
.29 \\
.09 \\
.25\end{array}$ & $\begin{array}{l}.00 \\
.01 \\
.00 \\
.22 \\
.09\end{array}$ & $\begin{array}{l}.13 \\
.01 \\
.11 \\
.00 \\
.00\end{array}$ & $\begin{array}{l}.00 \\
.00 \\
.29 \\
.15 \\
.20\end{array}$ & $\begin{array}{r}.17 \\
.18 \\
1.31 \\
.76 \\
.13\end{array}$ & $\begin{array}{l}.00 \\
.11 \\
.09 \\
.15 \\
.00\end{array}$ & $\begin{array}{l}.00 \\
.00 \\
.00 \\
.00 \\
.71\end{array}$ & $\begin{array}{l}.00 \\
.21 \\
.08 \\
.00 \\
.49\end{array}$ & $\begin{array}{l}.13 \\
.02 \\
.19 \\
.01 \\
.00\end{array}$ \\
\hline $\begin{array}{l}16 \\
17 \\
18 \\
19 \\
20\end{array}$ & $\begin{array}{l}.00 \\
.00 \\
.00 \\
.00 \\
.00\end{array}$ & $\begin{array}{l}.05 \\
.23 \\
.08 \\
.00 \\
.00\end{array}$ & $\begin{array}{l}.37 \\
.02 \\
.03 \\
.00 \\
.00\end{array}$ & $\begin{array}{l}.24 \\
.24 \\
.41 \\
.00 \\
.01\end{array}$ & $\begin{array}{l}.07 \\
.00 \\
.00 \\
.00 \\
.00\end{array}$ & $\begin{array}{l}.00 \\
.00 \\
.00 \\
.00 \\
.00\end{array}$ & $\begin{array}{l}.01 \\
.29 \\
.13 \\
.13 \\
.02\end{array}$ & $\begin{array}{l}.02 \\
.00 \\
.00 \\
.00 \\
.00\end{array}$ & $\begin{array}{l}.00 \\
.00 \\
.00 \\
.00 \\
.00\end{array}$ & $\begin{array}{l}.23 \\
.00 \\
.00 \\
.00 \\
.00\end{array}$ & $\begin{array}{l}.04 \\
.00 \\
.00 \\
.03 \\
.57\end{array}$ & $\begin{array}{l}.00 \\
.31 \\
.01 \\
.01 \\
.07\end{array}$ \\
\hline $\begin{array}{l}21 \\
22 \\
23 \\
24 \\
25\end{array}$ & $\begin{array}{l}.00 \\
.00 \\
.11 \\
.53 \\
.33\end{array}$ & $\begin{array}{r}.06 \\
.50 \\
.33 \\
.54 \\
1.20\end{array}$ & $\begin{array}{l}.00 \\
.02 \\
.14 \\
.08 \\
.01\end{array}$ & $\begin{array}{l}.41 \\
.02 \\
.00 \\
.00 \\
.09\end{array}$ & $\begin{array}{l}.00 \\
.00 \\
.04 \\
.19 \\
.36\end{array}$ & $\begin{array}{l}.00 \\
.00 \\
.42 \\
.16 \\
.00\end{array}$ & $\begin{array}{l}.18 \\
.27 \\
.00 \\
.00 \\
.17\end{array}$ & $\begin{array}{l}.00 \\
.19 \\
.02 \\
.03 \\
.02\end{array}$ & $\begin{array}{l}.00 \\
.00 \\
.08 \\
.00 \\
.00\end{array}$ & $\begin{array}{l}.00 \\
.00 \\
.00 \\
.00 \\
.00\end{array}$ & $\begin{array}{l}.14 \\
.03 \\
.09 \\
.18 \\
.05\end{array}$ & $\begin{array}{l}.04 \\
.00 \\
.00 \\
.00 \\
.04\end{array}$ \\
\hline $\begin{array}{l}26 \\
27 \\
28 \\
29 \\
30 \\
31\end{array}$ & $\begin{array}{l}.01 \\
.00 \\
.31 \\
.65 \\
.32 \\
.04\end{array}$ & $\begin{array}{l}.00 \\
.11 \\
.10 \\
.14 \\
.00 \\
.0\end{array}$ & $\begin{array}{l}.00 \\
.00 \\
.13 \\
.36 \\
.04 \\
.00\end{array}$ & $\begin{array}{l}.00 \\
.00 \\
.06 \\
.00 \\
.00 \\
.60\end{array}$ & $\begin{array}{l}.04 \\
.02 \\
.00 \\
-0 . \\
-0 .\end{array}$ & $\begin{array}{l}.00 \\
.00 \\
.00 \\
.00 \\
.02 \\
.00\end{array}$ & $\begin{array}{l}.34 \\
.06 \\
.04 \\
.00 \\
.05 \\
-.-\end{array}$ & $\begin{array}{l}.30 \\
.16 \\
.00 \\
.00 \\
.00 \\
.00\end{array}$ & $\begin{array}{l}.00 \\
.00 \\
.00 \\
.00 \\
.00 \\
-0\end{array}$ & $\begin{array}{l}.12 \\
.00 \\
.00 \\
.00 \\
.00 \\
.00\end{array}$ & $\begin{array}{l}.01 \\
.00 \\
.01 \\
.02 \\
.00 \\
.00\end{array}$ & $\begin{array}{l}.08 \\
.00 \\
.00 \\
.07 \\
.05 \\
-.\end{array}$ \\
\hline TOTAL & 2.85 & 5.46 & 9.58 & 5.28 & 3.36 & 1.63 & 3.16 & 3.40 & 0.73 & 1.12 & 1.95 & 3.52 \\
\hline
\end{tabular}

WTR YR 1978 TOTAL $\quad 42.12$

STATION NUMBER 14206330 BEAVERTON CR TRIS ON SW MURRAY QLVD

LATITUUE 452808 LONGITUUE 1224928

RAINFALL (IN.). WATER YEAR OCTOBER 1977 TO SEPTEMGEH 1978

\begin{tabular}{|c|c|c|c|c|c|c|c|c|c|c|c|c|}
\hline DAY & OCT & NOV & DEC & JAN & FES & MAR & $A P R$ & MAY & JUN & JUE & AUG & SFP \\
\hline $\begin{array}{l}1 \\
2 \\
3 \\
4 \\
5\end{array}$ & $\begin{array}{l}.00 \\
.00 \\
.00 \\
.00 \\
.00\end{array}$ & $\begin{array}{l}.43 \\
.09 \\
.01 \\
.15 \\
.19\end{array}$ & $\begin{array}{r}.06 \\
1.61 \\
.04 \\
.10 \\
.02\end{array}$ & $\begin{array}{l}.10 \\
.02 \\
.60 \\
.20 \\
.75\end{array}$ & $\begin{array}{l}.06 \\
.26 \\
.05 \\
.00 \\
.25\end{array}$ & $\begin{array}{l}.00 \\
.00 \\
.10 \\
.10 \\
.00\end{array}$ & $\begin{array}{l}.12 \\
.22 \\
.09 \\
.21 \\
.31\end{array}$ & $\begin{array}{l}.01 \\
.00 \\
.01 \\
.19 \\
.00\end{array}$ & $\begin{array}{l}.00 \\
.00 \\
.00 \\
.00 \\
.00\end{array}$ & $\begin{array}{l}.01 \\
.19 \\
.00 \\
.00 \\
.00\end{array}$ & $\begin{array}{l}.00 \\
.00 \\
.00 \\
.00 \\
.00\end{array}$ & $\begin{array}{l}.01 \\
.00 \\
.43 \\
.12 \\
.11\end{array}$ \\
\hline $\begin{array}{l}6 \\
7 \\
8 \\
9 \\
10\end{array}$ & $\begin{array}{l}.20 \\
.45 \\
.00 \\
.00 \\
.00\end{array}$ & $\begin{array}{l}11 \\
.05 \\
.00 \\
.00 \\
.00\end{array}$ & $\begin{array}{l}.16 \\
.05 \\
.00 \\
.20 \\
.40\end{array}$ & $\begin{array}{l}.01 \\
.30 \\
.36 \\
.36 \\
.02\end{array}$ & $\begin{array}{l}.25 \\
.75 \\
.25 \\
.09 \\
.00\end{array}$ & $\begin{array}{l}.07 \\
.51 \\
.03 \\
.00 \\
.01\end{array}$ & $\begin{array}{l}.00 \\
.00 \\
.00 \\
.00 \\
.00\end{array}$ & $\begin{array}{l}.00 \\
.00 \\
.00 \\
.04 \\
.11\end{array}$ & $\begin{array}{l}.00 \\
.00 \\
.00 \\
.12 \\
.12\end{array}$ & $\begin{array}{l}.00 \\
.00 \\
.00 \\
.00 \\
.00\end{array}$ & $\begin{array}{l}.00 \\
.00 \\
.00 \\
.00 \\
.00\end{array}$ & $\begin{array}{l}.01 \\
.19 \\
.27 \\
.86 \\
.50\end{array}$ \\
\hline $\begin{array}{l}11 \\
12 \\
13 \\
14 \\
15\end{array}$ & $\begin{array}{l}.00 \\
.01 \\
.01 \\
.00 \\
.04\end{array}$ & $\begin{array}{l}.10 \\
.30 \\
.20 \\
.35 \\
.07\end{array}$ & $\begin{array}{r}.80 \\
.85 \\
2.00 \\
.80 \\
1.30\end{array}$ & $\begin{array}{l}.12 \\
.02 \\
.35 \\
.11 \\
.31\end{array}$ & $\begin{array}{l}.00 \\
.05 \\
.00 \\
.27 \\
.13\end{array}$ & $\begin{array}{l}.17 \\
.04 \\
.14 \\
.01 \\
.00\end{array}$ & $\begin{array}{l}.00 \\
.00 \\
.32 \\
.14 \\
.20\end{array}$ & $\begin{array}{r}.26 \\
.18 \\
1.21 \\
.75 \\
.12\end{array}$ & $\begin{array}{l}.00 \\
.08 \\
.10 \\
.20 \\
.01\end{array}$ & $\begin{array}{l}.00 \\
.00 \\
.00 \\
.00 \\
.83\end{array}$ & $\begin{array}{l}.00 \\
.19 \\
.06 \\
.00 \\
.56\end{array}$ & $\begin{array}{l}.10 \\
.00 \\
.20 \\
.00 \\
.00\end{array}$ \\
\hline $\begin{array}{l}16 \\
17 \\
18 \\
19 \\
20\end{array}$ & $\begin{array}{l}.00 \\
.00 \\
.00 \\
.00 \\
.00\end{array}$ & $\begin{array}{l}.05 \\
.20 \\
.05 \\
.00 \\
.00\end{array}$ & $\begin{array}{l}.40 \\
.02 \\
.02 \\
.00 \\
.00\end{array}$ & $\begin{array}{l}.29 \\
.24 \\
.44 \\
.04 \\
.05\end{array}$ & $\begin{array}{l}.09 \\
.02 \\
.01 \\
.01 \\
.00\end{array}$ & $\begin{array}{l}.00 \\
.00 \\
.00 \\
.00 \\
.00\end{array}$ & $\begin{array}{l}.02 \\
.34 \\
.15 \\
.12 \\
.01\end{array}$ & $\begin{array}{l}.01 \\
.00 \\
.00 \\
.00 \\
.00\end{array}$ & $\begin{array}{l}.00 \\
.01 \\
.00 \\
.00 \\
.00\end{array}$ & $\begin{array}{l}.16 \\
.00 \\
.00 \\
.00 \\
.00\end{array}$ & $\begin{array}{l}.14 \\
.00 \\
.00 \\
.07 \\
.75\end{array}$ & $\begin{array}{l}.00 \\
.30 \\
.00 \\
.00 \\
.10\end{array}$ \\
\hline $\begin{array}{l}21 \\
22 \\
23 \\
24 \\
25\end{array}$ & $\begin{array}{l}.00 \\
.00 \\
.15 \\
.53 \\
.25\end{array}$ & $\begin{array}{r}.05 \\
.50 \\
.40 \\
.60 \\
1.10\end{array}$ & $\begin{array}{l}.00 \\
.03 \\
.15 \\
.10 \\
.00\end{array}$ & $\begin{array}{l}.40 \\
.05 \\
.00 \\
.00 \\
.13\end{array}$ & $\begin{array}{l}.00 \\
.00 \\
.00 \\
.10 \\
.40\end{array}$ & $\begin{array}{l}.00 \\
.00 \\
.41 \\
.22 \\
.01\end{array}$ & $\begin{array}{l}.21 \\
.23 \\
.00 \\
.00 \\
.22\end{array}$ & $\begin{array}{l}.00 \\
.35 \\
.20 \\
.02 \\
.04\end{array}$ & $\begin{array}{l}.00 \\
.01 \\
.10 \\
.01 \\
.00\end{array}$ & $\begin{array}{l}.00 \\
.00 \\
.00 \\
.00 \\
.00\end{array}$ & $\begin{array}{l}.07 \\
.01 \\
.09 \\
.19 \\
.07\end{array}$ & $\begin{array}{l}.05 \\
.00 \\
.00 \\
.00 \\
.05\end{array}$ \\
\hline $\begin{array}{l}26 \\
27 \\
28 \\
29 \\
30 \\
31\end{array}$ & $\begin{array}{l}.00 \\
.00 \\
.34 \\
.52 \\
.32 \\
.05\end{array}$ & $\begin{array}{l}.00 \\
110 \\
110 \\
110 \\
.00 \\
-.-0\end{array}$ & $\begin{array}{l}.00 \\
.00 \\
.10 \\
.40 \\
.05 \\
.00\end{array}$ & $\begin{array}{l}.01 \\
.01 \\
.09 \\
.00 \\
.02 \\
.62\end{array}$ & $\begin{array}{l}.00 \\
.00 \\
.00 \\
-0 \\
-\end{array}$ & $\begin{array}{l}.00 \\
.00 \\
.00 \\
.01 \\
.03 \\
.01\end{array}$ & $\begin{array}{l}.34 \\
.11 \\
.04 \\
.00 \\
.06 \\
-.0\end{array}$ & $\begin{array}{l}.32 \\
.12 \\
.00 \\
.00 \\
.00 \\
.00\end{array}$ & $\begin{array}{l}.00 \\
.00 \\
.00 \\
.00 \\
.00 \\
.\end{array}$ & $\begin{array}{l}.08 \\
.00 \\
.00 \\
.00 \\
.00 \\
.00\end{array}$ & $\begin{array}{l}.00 \\
.00 \\
.01 \\
.01 \\
.00 \\
.00\end{array}$ & $\begin{array}{l}.05 \\
.00 \\
.00 \\
.05 \\
.05 \\
-\cdots\end{array}$ \\
\hline TOTAL & 2.87 & 5.30 & 9.66 & 6.02 & 3.64 & 1.87 & 3.46 & 3.94 & 0.76 & 1.27 & 2.22 & 3.45 \\
\hline
\end{tabular}

WTR YR 1978 TOTAL 44.46 
TABLE 13.-DAILY PRECIPITATION-Continued

STATION NUMBER
LATITUUE 452852 LONGITUDE 1225141

RAINFALL (IN.), WAIEK YEAK OCTOBEK 1977 TO SERTEMBER 1978

\begin{tabular}{|c|c|c|c|c|c|c|c|c|c|c|c|c|}
\hline DAY & $\mathrm{OCr}$ & NOV & DEC & JAN & FEB & MAR & $\triangle P K$ & MAY & JUN & JUL & AUG & $5 F^{\circ}$ \\
\hline $\begin{array}{l}1 \\
2 \\
3 \\
4 \\
5\end{array}$ & $\begin{array}{l}.01 \\
.00 \\
.00 \\
.00 \\
.00\end{array}$ & $\begin{array}{l}.35 \\
.06 \\
.01 \\
.17 \\
.17\end{array}$ & $\begin{array}{r}.02 \\
1.36 \\
.01 \\
.10 \\
.02\end{array}$ & $\begin{array}{l}.02 \\
.00 \\
.19 \\
.62 \\
.78\end{array}$ & $\begin{array}{l}.63 \\
.24 \\
.05 \\
.00 \\
.29\end{array}$ & $\begin{array}{l}.00 \\
.00 \\
.05 \\
.06 \\
.00\end{array}$ & $\begin{array}{l}.11 \\
.25 \\
.05 \\
.17 \\
.25\end{array}$ & $\begin{array}{l}.02 \\
.00 \\
.00 \\
.03 \\
.04\end{array}$ & $\begin{array}{l}.00 \\
.00 \\
.00 \\
.00 \\
.00\end{array}$ & $\begin{array}{l}.05 \\
.14 \\
.00 \\
.00 \\
.00\end{array}$ & $\begin{array}{l}.00 \\
.00 \\
.00 \\
.00 \\
.00\end{array}$ & $\begin{array}{l}.00 \\
.00 \\
.45 \\
.10 \\
.10\end{array}$ \\
\hline $\begin{array}{r}6 \\
7 \\
8 \\
9 \\
10\end{array}$ & $\begin{array}{l}.19 \\
.28 \\
.00 \\
.00 \\
.00\end{array}$ & $\begin{array}{l}.14 \\
.08 \\
.01 \\
.01 \\
.00\end{array}$ & $\begin{array}{l}.16 \\
.02 \\
.01 \\
.17 \\
.41\end{array}$ & $\begin{array}{l}.03 \\
.30 \\
.38 \\
.38 \\
.02\end{array}$ & $\begin{array}{l}.18 \\
.65 \\
.22 \\
.08 \\
.01\end{array}$ & $\begin{array}{l}.07 \\
.49 \\
.03 \\
.00 \\
.00\end{array}$ & $\begin{array}{l}.00 \\
.00 \\
.00 \\
.00 \\
.00\end{array}$ & $\begin{array}{l}.00 \\
.00 \\
.00 \\
.05 \\
.08\end{array}$ & $\begin{array}{l}.00 \\
.00 \\
.00 \\
.16 \\
.13\end{array}$ & $\begin{array}{l}.00 \\
.00 \\
.00 \\
.00 \\
.00\end{array}$ & $\begin{array}{l}.00 \\
.00 \\
.00 \\
.00 \\
.00\end{array}$ & $\begin{array}{l}.00 \\
.70 \\
.23 \\
.00 \\
.37\end{array}$ \\
\hline $\begin{array}{l}11 \\
12 \\
13 \\
14 \\
15\end{array}$ & $\begin{array}{l}.00 \\
.00 \\
.02 \\
.00 \\
.00\end{array}$ & $\begin{array}{l}.09 \\
.27 \\
.14 \\
.33 \\
.07\end{array}$ & $\begin{array}{r}.78 \\
.79 \\
2.05 \\
.79 \\
1.25\end{array}$ & $\begin{array}{l}.11 \\
.01 \\
.28 \\
.11 \\
.25\end{array}$ & $\begin{array}{l}.00 \\
.01 \\
.00 \\
.28 \\
.13\end{array}$ & $\begin{array}{l}.16 \\
.04 \\
.12 \\
.00 \\
.00\end{array}$ & $\begin{array}{l}.00 \\
.00 \\
.35 \\
.08 \\
.18\end{array}$ & $\begin{array}{r}.17 \\
.14 \\
1.20 \\
.57 \\
.08\end{array}$ & $\begin{array}{l}.00 \\
.03 \\
.00 \\
.04 \\
.00\end{array}$ & $\begin{array}{l}.00 \\
.00 \\
.00 \\
.00 \\
.92\end{array}$ & $\begin{array}{l}.00 \\
.20 \\
.05 \\
.00 \\
.50\end{array}$ & $\begin{array}{l}.03 \\
.00 \\
.24 \\
.01 \\
.00\end{array}$ \\
\hline $\begin{array}{l}16 \\
17 \\
18 \\
19 \\
20\end{array}$ & $\begin{array}{l}.00 \\
.00 \\
.00 \\
.00 \\
.00\end{array}$ & $\begin{array}{l}.02 \\
.20 \\
.05 \\
.00 \\
.00\end{array}$ & $\begin{array}{l}.39 \\
.03 \\
.03 \\
.00 \\
.00\end{array}$ & $\begin{array}{l}.26 \\
.18 \\
.32 \\
.03 \\
.02\end{array}$ & $\begin{array}{l}.07 \\
.01 \\
.01 \\
.01 \\
.00\end{array}$ & $\begin{array}{l}.00 \\
.00 \\
.00 \\
.00 \\
.00\end{array}$ & $\begin{array}{l}.03 \\
.29 \\
.20 \\
.11 \\
.21\end{array}$ & $\begin{array}{l}.01 \\
.00 \\
.00 \\
.00 \\
.00\end{array}$ & $\begin{array}{l}.00 \\
.00 \\
.00 \\
.00 \\
.00\end{array}$ & $\begin{array}{l}.18 \\
.00 \\
.00 \\
.00 \\
.00\end{array}$ & $\begin{array}{l}.05 \\
.00 \\
.00 \\
.05 \\
.65\end{array}$ & $\begin{array}{l}.00 \\
.14 \\
.00 \\
.00 \\
.13\end{array}$ \\
\hline $\begin{array}{l}21 \\
22 \\
23 \\
24 \\
25\end{array}$ & $\begin{array}{l}.00 \\
.00 \\
.09 \\
.32 \\
.31\end{array}$ & $\begin{array}{l}.01 \\
.45 \\
.46 \\
.70 \\
1.09\end{array}$ & $\begin{array}{l}.00 \\
.04 \\
.15 \\
.07 \\
.00\end{array}$ & $\begin{array}{l}.37 \\
.05 \\
.00 \\
.00 \\
.11\end{array}$ & $\begin{array}{l}.00 \\
.00 \\
.00 \\
.09 \\
.29\end{array}$ & $\begin{array}{l}.00 \\
.00 \\
.30 \\
.18 \\
.01\end{array}$ & $\begin{array}{l}.17 \\
.31 \\
.00 \\
.00 \\
.07\end{array}$ & $\begin{array}{l}.00 \\
.09 \\
.02 \\
.04 \\
.03\end{array}$ & $\begin{array}{l}.00 \\
.01 \\
.13 \\
.00 \\
.00\end{array}$ & $\begin{array}{l}.00 \\
.00 \\
.00 \\
.00 \\
.00\end{array}$ & $\begin{array}{l}.10 \\
.00 \\
.10 \\
.20 \\
.05\end{array}$ & $\begin{array}{l}.00 \\
.00 \\
.00 \\
.00 \\
.00\end{array}$ \\
\hline $\begin{array}{l}26 \\
27 \\
28 \\
29 \\
30 \\
31\end{array}$ & $\begin{array}{l}.01 \\
.00 \\
.32 \\
.57 \\
.38 \\
.03\end{array}$ & $\begin{array}{l}.00 \\
.11 \\
.14 \\
.06 \\
.00 \\
.-\end{array}$ & $\begin{array}{l}.01 \\
.00 \\
.14 \\
.41 \\
.03 \\
.00\end{array}$ & $\begin{array}{l}.00 \\
.01 \\
.08 \\
.00 \\
.03 \\
.58\end{array}$ & $\begin{array}{l}.07 \\
.03 \\
.00 \\
--- \\
----\end{array}$ & $\begin{array}{l}.00 \\
.00 \\
.00 \\
.00 \\
.01 \\
.01\end{array}$ & $\begin{array}{r}.42 \\
.05 \\
.03 \\
.01 \\
.04 \\
-.-\end{array}$ & $\begin{array}{l}.24 \\
.10 \\
.00 \\
.00 \\
.00 \\
.00\end{array}$ & $\begin{array}{l}.00 \\
.00 \\
.00 \\
.00 \\
.00 \\
.0\end{array}$ & $\begin{array}{l}.03 \\
.00 \\
.00 \\
.00 \\
.00 \\
.00\end{array}$ & $\begin{array}{l}.00 \\
.00 \\
.03 \\
.00 \\
.00 \\
.00\end{array}$ & $\begin{array}{l}.00 \\
.00 \\
00 \\
.00 \\
.04 \\
-.-\end{array}$ \\
\hline TOTAL & 2.53 & 5.19 & 9.24 & 5.52 & 3.35 & 1.53 & 3.38 & 2.91 & 0.61 & 1.32 & 1.98 & 2.94 \\
\hline
\end{tabular}

WTR YR 1978 TOTAL $\quad 40.50$

STATION NUMBEK 14206950 RAIN GAGE AT KPAM-EM RAUIO UN COUNCIL CREST

KAINFALL (IN.), WAIER YEAR OCTUBEK 1977 TO SEPTFMHER 191A

\begin{tabular}{|c|c|c|c|c|c|c|c|c|c|c|c|c|}
\hline DAY & OCT & NOV & ot $\mathrm{C}$ & JAN & FEb & MAR & $A P H$ & MAY & $\therefore$ JUN & JUL & AUS & SFD \\
\hline $\begin{array}{l}1 \\
2 \\
3 \\
4 \\
5\end{array}$ & $\begin{array}{l}.00 \\
.00 \\
.00 \\
.00 \\
.00\end{array}$ & $\begin{array}{l}.43 \\
.02 \\
.00 \\
.08 \\
.15\end{array}$ & $\begin{array}{l}.05 \\
2.13 \\
.07 \\
.19 \\
.05\end{array}$ & $\begin{array}{l}.00 \\
.00 \\
.52 \\
.02 \\
.91\end{array}$ & $\begin{array}{l}.71 \\
.24 \\
.01 \\
.00 \\
.27\end{array}$ & $\begin{array}{l}.00 \\
.02 \\
.00 \\
.09 \\
.00\end{array}$ & $\begin{array}{l}.04 \\
.20 \\
.04 \\
.15 \\
.36\end{array}$ & $\begin{array}{l}.00 \\
.00 \\
.03 \\
.01 \\
.00\end{array}$ & $\begin{array}{l}.00 \\
.00 \\
.00 \\
.00 \\
.00\end{array}$ & $\begin{array}{l}.00 \\
.09 \\
.00 \\
.00 \\
.00\end{array}$ & $\begin{array}{l}.00 \\
.00 \\
.00 \\
.00 \\
.00\end{array}$ & $\begin{array}{l}.00 \\
.00 \\
.41 \\
.17 \\
.09\end{array}$ \\
\hline $\begin{array}{r}6 \\
7 \\
8 \\
9 \\
10\end{array}$ & $\begin{array}{l}.19 \\
.44 \\
.00 \\
.00 \\
.00\end{array}$ & $\begin{array}{l}.15 \\
.00 \\
.00 \\
.00 \\
.00\end{array}$ & $\begin{array}{r}.20 \\
.04 \\
.00 \\
.13 \\
.34\end{array}$ & $\begin{array}{l}.04 \\
.20 \\
.31 \\
.25 \\
.01\end{array}$ & $\begin{array}{r}.19 \\
.64 \\
.20 \\
.03 \\
.00\end{array}$ & $\begin{array}{l}.02 \\
.41 \\
.04 \\
.00 \\
.00\end{array}$ & $\begin{array}{l}.00 \\
.00 \\
.00 \\
.00 \\
.00\end{array}$ & $\begin{array}{l}.00 \\
.00 \\
.00 \\
.02 \\
.09\end{array}$ & $\begin{array}{l}.00 \\
.00 \\
.00 \\
.12 \\
.17\end{array}$ & $\begin{array}{l}.00 \\
.00 \\
.00 \\
.00 \\
.00\end{array}$ & $\begin{array}{l}.00 \\
.00 \\
.00 \\
.00 \\
.00\end{array}$ & $\begin{array}{l}.01 \\
.18 \\
.18 \\
.73 \\
.69\end{array}$ \\
\hline $\begin{array}{l}11 \\
12 \\
13 \\
14 \\
15\end{array}$ & $\begin{array}{l}.00 \\
.00 \\
.00 \\
.00 \\
.00\end{array}$ & $\begin{array}{l}.13 \\
.52 \\
.23 \\
.36 \\
.09\end{array}$ & $\begin{array}{l}1.09 \\
.95 \\
2.56 \\
.83 \\
1.15\end{array}$ & $\begin{array}{l}.07 \\
.02 \\
.24 \\
.07 \\
.25\end{array}$ & $\begin{array}{l}.00 \\
.00 \\
.00 \\
.27 \\
.08\end{array}$ & $\begin{array}{l}.16 \\
.03 \\
.17 \\
.00 \\
.00\end{array}$ & $\begin{array}{l}.00 \\
.00 \\
.23 \\
.20 \\
.27\end{array}$ & $\begin{array}{r}.23 \\
.11 \\
.91 \\
.29 \\
.11\end{array}$ & $\begin{array}{l}.00 \\
.10 \\
.04 \\
.21 \\
.00\end{array}$ & $\begin{array}{l}.00 \\
.00 \\
.00 \\
.00 \\
.71\end{array}$ & $\begin{array}{l}.00 \\
.50 \\
.05 \\
.00 \\
.84\end{array}$ & $\begin{array}{l}.00 \\
.00 \\
.18 \\
.00 \\
.00\end{array}$ \\
\hline $\begin{array}{l}16 \\
17 \\
18 \\
19 \\
20\end{array}$ & $\begin{array}{l}.00 \\
.00 \\
.00 \\
.00 \\
.00\end{array}$ & $\begin{array}{l}.04 \\
.08 \\
.16 \\
.00 \\
.00\end{array}$ & $\begin{array}{r}.43 \\
.03 \\
.00 \\
.00 \\
.00\end{array}$ & $\begin{array}{l}.28 \\
.25 \\
.34 \\
.06 \\
.05\end{array}$ & $\begin{array}{l}.04 \\
.01 \\
.00 \\
.00 \\
.00\end{array}$ & $\begin{array}{l}.00 \\
.00 \\
.00 \\
.00 \\
.00\end{array}$ & $\begin{array}{r}.03 \\
.29 \\
.17 \\
.113 \\
.13 \\
.07\end{array}$ & $\begin{array}{l}.00 \\
.00 \\
.00 \\
.00 \\
.00\end{array}$ & $\begin{array}{l}.00 \\
.00 \\
.00 \\
.00 \\
.00\end{array}$ & $\begin{array}{l}.33 \\
.00 \\
.00 \\
.00 \\
.00\end{array}$ & $\begin{array}{l}.02 \\
.00 \\
.00 \\
.04 \\
.52\end{array}$ & $\begin{array}{l}.05 \\
.28 \\
.00 \\
.00 \\
.05\end{array}$ \\
\hline $\begin{array}{l}21 \\
22 \\
23 \\
24 \\
25\end{array}$ & $\begin{array}{l}.00 \\
.00 \\
.13 \\
.32 \\
.57\end{array}$ & $\begin{array}{l}.00 \\
.55 \\
.40 \\
.57 \\
1.29\end{array}$ & $\begin{array}{r}.00 \\
.00 \\
.02 \\
.02 \\
.16 \\
.01\end{array}$ & $\begin{array}{l}.51 \\
.02 \\
.00 \\
.00 \\
.14\end{array}$ & $\begin{array}{l}.00 \\
.00 \\
.05 \\
.18 \\
.64\end{array}$ & $\begin{array}{l}.00 \\
.00 \\
.39 \\
.23 \\
.00\end{array}$ & $\begin{array}{r}.12 \\
.12 \\
.00 \\
.00 \\
.16\end{array}$ & $\begin{array}{l}.00 \\
.05 \\
.00 \\
.15 \\
.00\end{array}$ & $\begin{array}{l}.00 \\
.00 \\
.12 \\
.00 \\
.00\end{array}$ & $\begin{array}{l}.00 \\
.00 \\
.00 \\
.00 \\
.00\end{array}$ & $\begin{array}{l}.06 \\
.00 \\
.09 \\
.36 \\
.11\end{array}$ & $\begin{array}{l}.00 \\
.00 \\
.00 \\
.00 \\
.00\end{array}$ \\
\hline $\begin{array}{l}26 \\
27 \\
28 \\
29 \\
30 \\
31\end{array}$ & $\begin{array}{l}.01 \\
.00 \\
.34 \\
.67 \\
.26 \\
.09\end{array}$ & $\begin{array}{l}.00 \\
.13 \\
.11 \\
.16 \\
.00 \\
.--\end{array}$ & $\begin{array}{r}.00 \\
.00 \\
.00 \\
.21 \\
.04 \\
.00\end{array}$ & $\begin{array}{l}.00 \\
.00 \\
.08 \\
.00 \\
.00 \\
.78\end{array}$ & $\begin{array}{r}.20 \\
.00 \\
.00 \\
--0 \\
---\end{array}$ & $\begin{array}{l}.00 \\
.00 \\
.00 \\
.00 \\
.09 \\
.00\end{array}$ & $\because \begin{array}{r}.50 \\
.09 \\
.04 \\
.00 \\
.04 \\
.0-0\end{array}$ & $\begin{array}{l}.25 \\
.16 \\
.00 \\
.00 \\
.00 \\
.00 \\
.00\end{array}$ & $\begin{array}{l}.00 \\
.00 \\
.00 \\
.00 \\
.00 \\
. .-\end{array}$ & $\begin{array}{l}.01 \\
.00 \\
.00 \\
.00 \\
.00 \\
.00\end{array}$ & $\begin{array}{l}.00 \\
.00 \\
.00 \\
.00 \\
.00 \\
.00\end{array}$ & $\begin{array}{l}.00 \\
.00 \\
.00 \\
.00 \\
.07 \\
. .0\end{array}$ \\
\hline IOTAL & 3.02 & 6.21 & 10.72 & $=5.47$ & 3.81 & l.bs & 3.25 & 2.41 & 0.61 & 1.13 & 2.65 & 3.04 \\
\hline
\end{tabular}


STAIION NUMBER
LATITUUE 452917 LONGITUDE 1224401

HAI NFALL (IN.), WATER YEAR OCTUBEA 1977 TO SEPTEMBER 1978

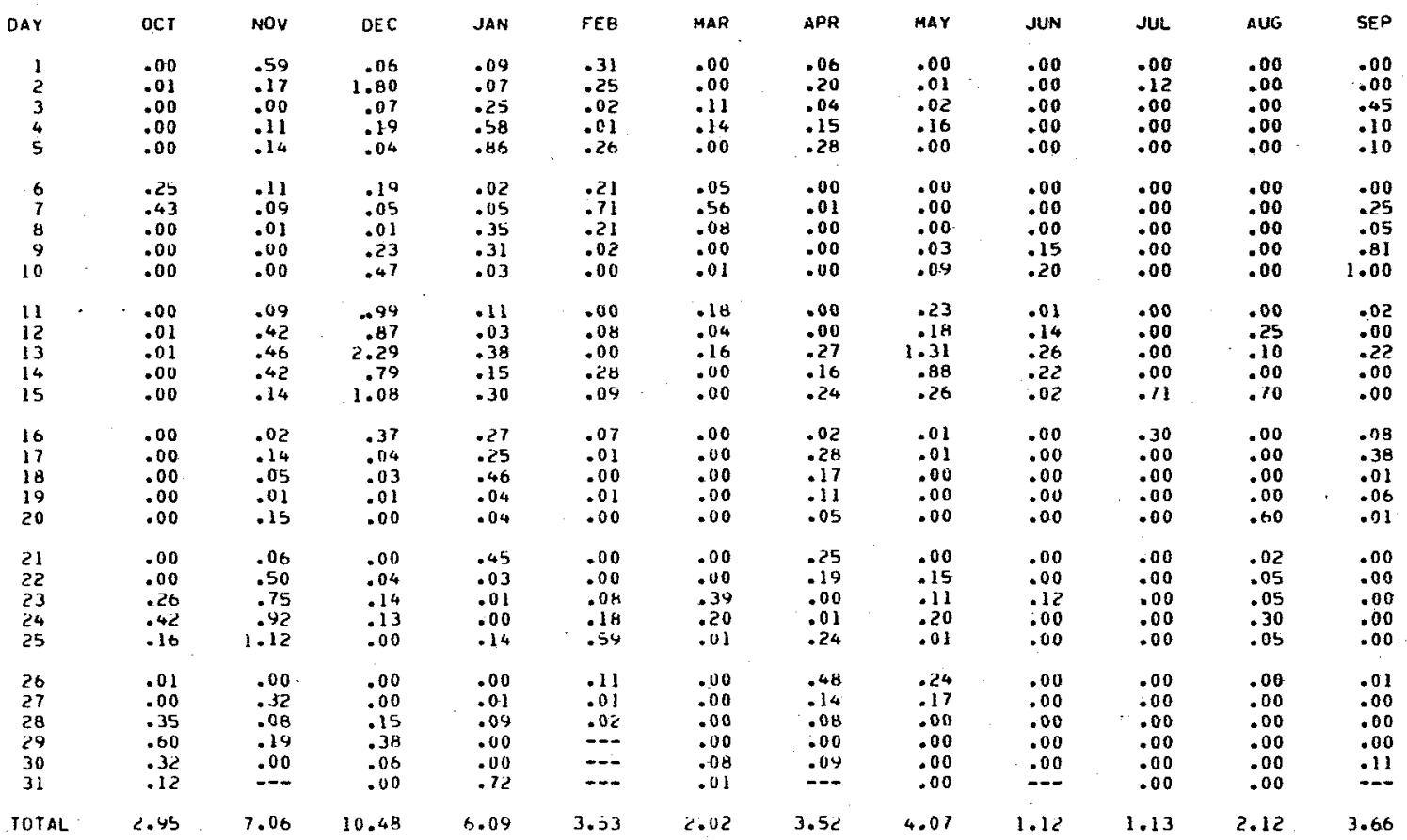

WT YK 1970 TUTAL 47.75

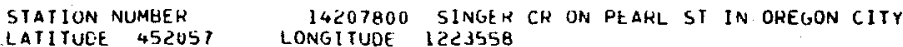

HAINFALL (IN.), WATEH YEAR OCTUBER 1977 TO SEPTEMBER IY78

\begin{tabular}{|c|c|c|c|c|c|c|c|c|c|c|c|c|}
\hline DAY & OCI & NuV & DF C & JAN & $F \varepsilon_{\forall}$ & MAH & $A P R$ & MAY & JUN & JUL & AUG & SFP \\
\hline $\begin{array}{l}1 \\
2 \\
3 \\
4 \\
5\end{array}$ & $\begin{array}{l}.01 \\
.00 \\
.01 \\
.01 \\
.00\end{array}$ & $\begin{array}{l}.59 \\
.17 \\
.00 \\
.11 \\
.14\end{array}$ & $\begin{array}{r}.10 \\
2.21 \\
.27 \\
.09 \\
.04\end{array}$ & $\begin{array}{l}.33 \\
.06 \\
.42 \\
.31 \\
.68\end{array}$ & $\begin{array}{l}.53 \\
.40 \\
.06 \\
.00 \\
.20\end{array}$ & $\begin{array}{l}.00 \\
.00 \\
.09 \\
.19 \\
.00\end{array}$ & $\begin{array}{l}.14 \\
.39 \\
.04 \\
.17 \\
.53\end{array}$ & $\begin{array}{l}.00 \\
.00 \\
.02 \\
.09 \\
.00\end{array}$ & $\begin{array}{l}.00 \\
.00 \\
.00 \\
.00 \\
.00\end{array}$ & $\begin{array}{l}.00 \\
.35 \\
.09 \\
.00 \\
.00\end{array}$ & $\begin{array}{l}.00 \\
.00 \\
.00 \\
.00 \\
.00\end{array}$ & $\begin{array}{l}.00 \\
.00 \\
.30 \\
.10 \\
.15\end{array}$ \\
\hline $\begin{array}{r}6 \\
7 \\
8 \\
9 \\
10\end{array}$ & $\begin{array}{l}.39 \\
.21 \\
.00 \\
.00 \\
.00\end{array}$ & $\begin{array}{l}.11 \\
.09 \\
.01 \\
.00 \\
.00\end{array}$ & $\begin{array}{l}.04 \\
.05 \\
.01 \\
.20 \\
.50\end{array}$ & $\begin{array}{l}.06 \\
.25 \\
.36 \\
.20 \\
.07\end{array}$ & $\begin{array}{l}.25 \\
.75 \\
.20 \\
.05 \\
.00\end{array}$ & $\begin{array}{l}.05 \\
.40 \\
.08 \\
.00 \\
.00\end{array}$ & $\begin{array}{l}.01 \\
.00 \\
.00 \\
.00 \\
.00\end{array}$ & $\begin{array}{l}.01 \\
.00 \\
.00 \\
.10 \\
.26\end{array}$ & $\begin{array}{l}.00 \\
.00 \\
.00 \\
.31 \\
.50\end{array}$ & $\begin{array}{l}.00 \\
.00 \\
.00 \\
.00 \\
.00\end{array}$ & $\begin{array}{l}.00 \\
.00 \\
.00 \\
.00 \\
.00\end{array}$ & $\begin{array}{r}.29 \\
.25 \\
.33 \\
.41 \\
.10\end{array}$ \\
\hline $\begin{array}{l}11 \\
12 \\
13 \\
14 \\
15\end{array}$ & $\begin{array}{l}.00 \\
.00 \\
.05 \\
.00 \\
.00\end{array}$ & $\begin{array}{l}.09 \\
.42 \\
.46 \\
.42 \\
.14\end{array}$ & $\begin{array}{r}1.29 \\
.77 \\
1.96 \\
.95 \\
.99\end{array}$ & $\begin{array}{l}.12 \\
.15 \\
.40 \\
.10 \\
.35\end{array}$ & $\begin{array}{l}.00 \\
.02 \\
.00 \\
.20 \\
.10\end{array}$ & $\begin{array}{l}.38 \\
.01 \\
.14 \\
.00 \\
.00\end{array}$ & $\begin{array}{l}.00 \\
.00 \\
.24 \\
.48 \\
.27\end{array}$ & $\begin{array}{r}.11 \\
.70 \\
1.45 \\
1.08 \\
.02\end{array}$ & $\begin{array}{l}.02 \\
.13 \\
.24 \\
.19 \\
.04\end{array}$ & $\begin{array}{l}.00 \\
.00 \\
.00 \\
.00 \\
.87\end{array}$ & $\begin{array}{l}.00 \\
.26 \\
.10 \\
.00 \\
.75\end{array}$ & $\begin{array}{l}.01 \\
.19 \\
.01 \\
.02 \\
.05\end{array}$ \\
\hline $\begin{array}{l}16 \\
17 \\
18 \\
19 \\
20\end{array}$ & $\begin{array}{l}.00 \\
.00 \\
.00 \\
.00 \\
.00\end{array}$ & $\begin{array}{l}.02 \\
.14 \\
.05 \\
.01 \\
.15\end{array}$ & $\begin{array}{l}.35 \\
.10 \\
.10 \\
.02 \\
.00\end{array}$ & $\begin{array}{l}.40 \\
.25 \\
.55 \\
.05 \\
.10\end{array}$ & $\begin{array}{l}.03 \\
.00 \\
.03 \\
.00 \\
.00\end{array}$ & $\begin{array}{l}.00 \\
.00 \\
.00 \\
.00 \\
.00\end{array}$ & $\begin{array}{l}.14 \\
.26 \\
.20 \\
.31 \\
.24\end{array}$ & $\begin{array}{l}.00 \\
.00 \\
.01 \\
.00 \\
.00\end{array}$ & $\begin{array}{l}.00 \\
.00 \\
.00 \\
.00 \\
.00\end{array}$ & $\begin{array}{l}.26 \\
.00 \\
.00 \\
.00 \\
.00\end{array}$ & $\begin{array}{l}.30 \\
.00 \\
.00 \\
.05 \\
.55\end{array}$ & $\begin{array}{l}.26 \\
.01 \\
.00 \\
.04 \\
.01\end{array}$ \\
\hline $\begin{array}{l}26 \\
27 \\
28 \\
29 \\
30 \\
31\end{array}$ & $\begin{array}{l}.01 \\
.00 \\
.35 \\
.60 \\
.32 \\
.12\end{array}$ & $\begin{array}{l}.00 \\
.32 \\
.08 \\
.19 \\
.00 \\
.0\end{array}$ & $\begin{array}{l}.00 \\
.00 \\
.15 \\
.50 \\
.05 \\
.00\end{array}$ & $\begin{array}{l}.00 \\
.00 \\
.05 \\
.00 \\
.03 \\
.07\end{array}$ & \begin{tabular}{l}
.23 \\
.00 \\
.00 \\
$-0-$ \\
\hdashline-0
\end{tabular} & $\begin{array}{l}.00 \\
.00 \\
.00 \\
.00 \\
.16 \\
.11\end{array}$ & $\begin{array}{l}.75 \\
.02 \\
.02 \\
.00 \\
.05 \\
-.-\end{array}$ & $\begin{array}{l}.30 \\
.20 \\
.00 \\
.00 \\
.00 \\
.00\end{array}$ & $\begin{array}{l}.00 \\
.00 \\
.00 \\
.00 \\
.00 \\
.00\end{array}$ & $\begin{array}{l}.06 \\
.00 \\
.00 \\
.00 \\
.00 \\
.00\end{array}$ & $\begin{array}{l}.00 \\
.00 \\
.00 \\
.00 \\
.00 \\
.00\end{array}$ & $\begin{array}{l}.00 \\
.00 \\
.00 \\
.00 \\
.05 \\
-0\end{array}$ \\
\hline TOTAL & 2.98 & 7.06 & 11.75 & 5.98 & 4.09 & 2.16 & 5.59 & 4.49 & 1.77 & 1.63 & 2.611 & 2.84 \\
\hline
\end{tabular}



STATION NUMBER
LATI 14210400 NOTE 452506
LONGITUDE 1222431

RAINFALL (IN.), WATER YEAR OCTOBER 1977 TO SEPTEMBER 1978

\begin{tabular}{|c|c|c|c|c|c|c|c|c|c|c|c|c|}
\hline OAY & OCT & Nov & $D E C$ & JAN & FEB & MAR & APR & MAY & JUN & JUL & AUG & SEP \\
\hline $\begin{array}{l}1 \\
2 \\
3 \\
4 \\
5\end{array}$ & $\begin{array}{l}.01 \\
.00 \\
.00 \\
.00 \\
.00\end{array}$ & $\begin{array}{l}.67 \\
.22 \\
.01 \\
.16 \\
.19\end{array}$ & $\begin{array}{r}.07 \\
1.68 \\
.36 \\
.09 \\
.11\end{array}$ & $\begin{array}{l}.00 \\
.00 \\
.00 \\
.50 \\
.10\end{array}$ & $\begin{array}{l}.55 \\
.34 \\
.05 \\
.00 \\
.21\end{array}$ & $\begin{array}{l}.00 \\
.00 \\
.07 \\
.19 \\
.00\end{array}$ & $\begin{array}{l}.05 \\
.17 \\
.15 \\
.29 \\
.23\end{array}$ & $\begin{array}{l}.00 \\
.00 \\
.02 \\
.35 \\
.01\end{array}$ & $\begin{array}{l}.00 \\
.00 \\
.00 \\
.00 \\
.00\end{array}$ & $\begin{array}{l}.12 \\
.04 \\
.00 \\
.00 \\
.00\end{array}$ & $\begin{array}{l}.00 \\
.00 \\
.00 \\
-00 \\
.00\end{array}$ & $\begin{array}{l}.01 \\
.01 \\
.20 \\
.15 \\
.25\end{array}$ \\
\hline $\begin{array}{r}6 \\
7 \\
8 \\
9 \\
10\end{array}$ & $\begin{array}{l}.42 \\
.34 \\
.00 \\
.00 \\
.00\end{array}$ & $\begin{array}{l}.10 \\
.16 \\
.06 \\
.00 \\
.00\end{array}$ & $\begin{array}{l}.45 \\
.02 \\
.03 \\
.20 \\
.46\end{array}$ & $\begin{array}{l}.00 \\
.20 \\
.30 \\
.15 \\
.07\end{array}$ & $\begin{array}{l}.23 \\
.57 \\
.14 \\
.06 \\
.01\end{array}$ & $\begin{array}{l}.00 \\
.00 \\
.00 \\
.00 \\
.00\end{array}$ & $\begin{array}{l}.01 \\
.01 \\
.00 \\
.00 \\
.00\end{array}$ & $\begin{array}{l}.00 \\
.00 \\
.00 \\
.17 \\
.17\end{array}$ & $\begin{array}{l}.00 \\
.00 \\
.00 \\
.29 \\
.35\end{array}$ & $\begin{array}{l}.00 \\
.00 \\
.00 \\
.00 \\
.00\end{array}$ & $\begin{array}{l}.00 \\
.00 \\
.00 \\
.00 \\
.00\end{array}$ & $\begin{array}{l}.01 \\
.24 \\
.23 \\
.21 \\
.44\end{array}$ \\
\hline $\begin{array}{l}11 \\
12 \\
13 \\
14 \\
15\end{array}$ & $\begin{array}{l}.00 \\
.00 \\
.07 \\
.00 \\
.00\end{array}$ & $\begin{array}{l}.08 \\
.24 \\
.45 \\
.33 \\
.13\end{array}$ & $\begin{array}{r}1.67 \\
.68 \\
1.69 \\
1.11 \\
.42\end{array}$ & $\begin{array}{l}.18 \\
.10 \\
.31 \\
.19 \\
.23\end{array}$ & $\begin{array}{l}.00 \\
.02 \\
.00 \\
.25 \\
.10\end{array}$ & $\begin{array}{l}.00 \\
.00 \\
.00 \\
.00 \\
.00\end{array}$ & $\begin{array}{l}.00 \\
.00 \\
.12 \\
.45 \\
.34\end{array}$ & $\begin{array}{r}.23 \\
.26 \\
1.14 \\
1.20 \\
.12\end{array}$ & $\begin{array}{l}.01 \\
.15 \\
.34 \\
.89 \\
.01\end{array}$ & $\begin{array}{r}.00 \\
.00 \\
.00 \\
.00 \\
1.00\end{array}$ & $\begin{array}{r}.00 \\
.63 \\
.11 \\
.00 \\
1.47\end{array}$ & $\begin{array}{l}.01 \\
.00 \\
.19 \\
.09 \\
.00\end{array}$ \\
\hline $\begin{array}{l}16 \\
17 \\
18 \\
19 \\
20\end{array}$ & $\begin{array}{l}.00 \\
.00 \\
.00 \\
.00 \\
.00\end{array}$ & $\begin{array}{l}.01 \\
.22 \\
.19 \\
.14 \\
.12\end{array}$ & $\begin{array}{l}.30 \\
.15 \\
.10 \\
.01 \\
.00\end{array}$ & $\begin{array}{l}.49 \\
.23 \\
.54 \\
.16 \\
.09\end{array}$ & $\begin{array}{l}.03 \\
.04 \\
.02 \\
.00 \\
.01\end{array}$ & $\begin{array}{l}.00 \\
.00 \\
.00 \\
.00 \\
.00\end{array}$ & $\begin{array}{l}.13 \\
.37 \\
.10 \\
.39 \\
.16\end{array}$ & $\begin{array}{l}.00 \\
.00 \\
.00 \\
.00 \\
.00\end{array}$ & $\begin{array}{l}.00 \\
.00 \\
.00 \\
.00 \\
.00\end{array}$ & $\begin{array}{l}.40 \\
.00 \\
.00 \\
.00 \\
.00\end{array}$ & $\begin{array}{l}.34 \\
.00 \\
.00 \\
.09 \\
.57\end{array}$ & $\begin{array}{l}.11 \\
.15 \\
.00 \\
.04 \\
.00\end{array}$ \\
\hline $\begin{array}{l}21 \\
22 \\
23 \\
.24 \\
25\end{array}$ & $\begin{array}{l}.00 \\
.00 \\
.19 \\
.41 \\
.32\end{array}$ & $\begin{array}{l}.08 \\
.55 \\
.80 \\
.86 \\
.93\end{array}$ & $\begin{array}{l}.00 \\
.02 \\
.20 \\
.30 \\
.00\end{array}$ & $\begin{array}{l}.59 \\
.09 \\
.00 \\
.01 \\
.23\end{array}$ & $\begin{array}{l}.00 \\
.00 \\
.03 \\
.43 \\
.70\end{array}$ & $\begin{array}{l}.00 \\
.00 \\
.25 \\
.15 \\
.06\end{array}$ & $\begin{array}{l}.33 \\
.40 \\
.00 \\
.00 \\
.29\end{array}$ & $\begin{array}{l}.00 \\
.02 \\
.01 \\
.21 \\
.01\end{array}$ & $\begin{array}{l}.00 \\
.00 \\
.16 \\
.06 \\
.00\end{array}$ & $\begin{array}{l}.00 \\
.00 \\
.00 \\
.00 \\
.00\end{array}$ & $\begin{array}{l}.09 \\
.17 \\
.11 \\
.42 \\
.10\end{array}$ & $\begin{array}{l}.01 \\
.04 \\
.01 \\
.00 \\
.00\end{array}$ \\
\hline $\begin{array}{r}26 \\
27 \\
.28 \\
29 \\
30 \\
31\end{array}$ & $\begin{array}{l}.00 \\
.00 \\
.33 \\
.47 \\
.41 \\
.23\end{array}$ & $\begin{array}{l}.00 \\
.52 \\
.10 \\
.25 \\
.00 \\
. .0\end{array}$ & $\begin{array}{l}.02 \\
.03 \\
.10 \\
.20 \\
.00 \\
.00\end{array}$ & $\begin{array}{l}.01 \\
.02 \\
.21 \\
.00 \\
.00 \\
.52\end{array}$ & $\begin{array}{l}.28 \\
.07 \\
.00 \\
-0- \\
-\end{array}$ & $\begin{array}{r}.00 \\
.18 \\
.00 \\
.00 \\
.13 \\
.00\end{array}$ & $\begin{array}{l}.95 \\
.48 \\
.03 \\
.01 \\
.11 \\
\end{array}$ & $\begin{array}{l}.20 \\
.29 \\
.00 \\
.00 \\
.00 \\
.00\end{array}$ & $\begin{array}{l}.00 \\
.00 \\
.00 \\
.00 \\
.00 \\
-00\end{array}$ & $\begin{array}{l}.01 \\
.00 \\
.00 \\
.00 \\
.00 \\
.00\end{array}$ & $\begin{array}{l}.01 \\
.01 \\
.02 \\
.00 \\
.00 \\
.00\end{array}$ & $\begin{array}{l}.00 \\
.05 \\
.00 \\
.00 \\
.12 \\
-12\end{array}$ \\
\hline TOTAL & 3.20 & 7.57 & 10.46 & 5.52 & 4.14 & 1.03 & 5.57 & 4.41 & 2.26 & 1.57 & 4.14 & 2.57 \\
\hline
\end{tabular}

WTR YR 1978 TOTAL 52.44

STATION NUMBER 14211105 RAIN GAGE ON VIEW DR IN ROBINHOOO

LATITUOE 453224 LONGITUDE 1223853

RAINFALL (IN.), WATER YEAR OCTOBER 1977 TO SEPTEMBER 1978

\begin{tabular}{|c|c|c|c|c|c|c|c|c|c|c|c|c|}
\hline DAY & OCT & NOV & DEC & JAN & FEB & MAR & APR & MAY & JUN & JUL & AUG & SEP \\
\hline $\begin{array}{l}1 \\
2 \\
3 \\
4 \\
5\end{array}$ & $\begin{array}{l}.00 \\
.00 \\
.00 \\
.01 \\
.00\end{array}$ & $\begin{array}{l}.64 \\
.19 \\
.00 \\
.11 \\
.17\end{array}$ & $\begin{array}{r}.15 \\
2.43 \\
.20 \\
.09 \\
.06\end{array}$ & $\begin{array}{l}.08 \\
.00 \\
.06 \\
.76 \\
.68\end{array}$ & $\begin{array}{l}.63 \\
.43 \\
.05 \\
.00 \\
.27\end{array}$ & $\begin{array}{l}.00 \\
.00 \\
.08 \\
.19 \\
.00\end{array}$ & $\begin{array}{l}.08 \\
.41 \\
.04 \\
.13 \\
.33\end{array}$ & $\begin{array}{l}.00 \\
.00 \\
.02 \\
.07 \\
.00\end{array}$ & $\begin{array}{l}.00 \\
.00 \\
.00 \\
.00 \\
.00\end{array}$ & $\begin{array}{l}.00 \\
.20 \\
.01 \\
.00 \\
.00\end{array}$ & $\begin{array}{l}.00 \\
.00 \\
.00 \\
.00 \\
.00\end{array}$ & $\begin{array}{l}.01 \\
.02 \\
.38 \\
.15 \\
.17\end{array}$ \\
\hline $\begin{array}{r}6 \\
7 \\
8 \\
9 \\
10\end{array}$ & $\begin{array}{l}.42 \\
.28 \\
.01 \\
.00 \\
.00\end{array}$ & $\begin{array}{l}.09 \\
.16 \\
.01 \\
.00 \\
.00\end{array}$ & $\begin{array}{l}.77 \\
.04 \\
.02 \\
.22 \\
.50\end{array}$ & $\begin{array}{l}.11 \\
.28 \\
.37 \\
.20 \\
.04\end{array}$ & $\begin{array}{l}.23 \\
.89 \\
.20 \\
.07 \\
.00\end{array}$ & $\begin{array}{l}.04 \\
.43 \\
.07 \\
.00 \\
.00\end{array}$ & $\begin{array}{l}.01 \\
.00 \\
.00 \\
.00 \\
.00\end{array}$ & $\begin{array}{l}.00 \\
.00 \\
.00 \\
.05 \\
.19\end{array}$ & $\begin{array}{l}.00 \\
.00 \\
.00 \\
.18 \\
.38\end{array}$ & $\begin{array}{l}.00 \\
.00 \\
.00 \\
.00 \\
.00\end{array}$ & $\begin{array}{l}.00 \\
.00 \\
.00 \\
.00 \\
.00\end{array}$ & $\begin{array}{l}.01 \\
.27 \\
.27 \\
.53 \\
.42\end{array}$ \\
\hline $\begin{array}{l}11 \\
12 \\
13 \\
14 \\
15\end{array}$ & $\begin{array}{l}.00 \\
.00 \\
.03 \\
.00 \\
.00\end{array}$ & $\begin{array}{l}.10 \\
.43 \\
.44 \\
.50 \\
.13\end{array}$ & $\begin{array}{l}1.71 \\
.85 \\
2.01 \\
1.00 \\
1.01\end{array}$ & $\begin{array}{l}.14 \\
.09 \\
: 36 \\
.12 \\
.31\end{array}$ & $\begin{array}{r}.00 \\
.03 \\
.00 \\
.24 \\
.10\end{array}$ & $\begin{array}{l}.25 \\
.02 \\
.20 \\
.00 \\
.00\end{array}$ & $\begin{array}{l}.00 \\
.00 \\
.19 \\
.34 \\
.28\end{array}$ & $\begin{array}{r}.19 \\
.31 \\
1.49 \\
1.08 \\
.17\end{array}$ & $\begin{array}{l}.02 \\
.16 \\
.28 \\
.73 \\
.02\end{array}$ & $\begin{array}{l}.00 \\
.00 \\
.00 \\
.00 \\
.87\end{array}$ & $\begin{array}{l}.00 \\
.44 \\
.05 \\
.00 \\
.81\end{array}$ & $\begin{array}{l}.01 \\
.00 \\
.18 \\
.01 \\
.00\end{array}$ \\
\hline $\begin{array}{l}16 \\
1.7 \\
18 \\
19 \\
20\end{array}$ & $\begin{array}{l}.00 \\
.00 \\
.00 \\
.00 \\
.00\end{array}$ & $\begin{array}{l}.01 \\
.22 \\
.21 \\
.01 \\
.15\end{array}$ & $\begin{array}{l}.39 \\
.10 \\
.08 \\
.02 \\
.00\end{array}$ & $\begin{array}{l}.40 \\
.24 \\
.54 \\
.12 \\
.02\end{array}$ & $\begin{array}{l}.03 \\
.02 \\
.00 \\
.00 \\
.00\end{array}$ & $\begin{array}{l}.00 \\
.00 \\
.00 \\
.00 \\
.00\end{array}$ & $\begin{array}{l}.23 \\
.33 \\
.13 \\
.27 \\
.19\end{array}$ & $\begin{array}{l}.00 \\
.00 \\
.00 \\
.00 \\
.00\end{array}$ & $\begin{array}{l}.00 \\
.00 \\
.00 \\
.00 \\
.00\end{array}$ & $\begin{array}{l}.29 \\
.00 \\
.00 \\
.00 \\
.00\end{array}$ & $\begin{array}{r}.43 \\
.00 \\
.01 \\
.06 \\
.56\end{array}$ & $\begin{array}{l}.00 \\
.26 \\
.01 \\
.00 \\
.06\end{array}$ \\
\hline $\begin{array}{l}21 \\
22 \\
23 \\
24 \\
25\end{array}$ & $\begin{array}{l}.00 \\
.00 \\
.31 \\
.57 \\
.25\end{array}$ & $\begin{array}{r}.06 \\
.50 \\
.85 \\
.92 \\
1.12\end{array}$ & $\begin{array}{l}.00 \\
.04 \\
.17 \\
.25 \\
.00\end{array}$ & $\begin{array}{r}.44 \\
.03 \\
.00 \\
.00 \\
.00 \\
.16\end{array}$ & $\begin{array}{l}.00 \\
.01 \\
.04 \\
.26 \\
.76\end{array}$ & $\begin{array}{r}.00 \\
.00 \\
.53 \\
.31 \\
.02\end{array}$ & $\begin{array}{l}.47 \\
.53 \\
.01 \\
.00 \\
.33\end{array}$ & $\begin{array}{l}.00 \\
.02 \\
.01 \\
.07 \\
.00\end{array}$ & $\begin{array}{l}.00 \\
.00 \\
.19 \\
.01 \\
.00\end{array}$ & $\begin{array}{l}.00 \\
.00 \\
.00 \\
.00 \\
.00\end{array}$ & $\begin{array}{l}.03 \\
.01 \\
.16 \\
.67 \\
.12\end{array}$ & $\begin{array}{l}.00 \\
.04 \\
.00 \\
.00 \\
.00\end{array}$ \\
\hline $\begin{array}{l}26 \\
27 \\
28 \\
29 \\
30 \\
31\end{array}$ & $\begin{array}{r}.01 \\
.00 \\
.39 \\
1.04 \\
.30 \\
.13\end{array}$ & $\begin{array}{l}.00 \\
.32 \\
.08 \\
.19 \\
.00 \\
-0 .\end{array}$ & $\begin{array}{r}.00 \\
.00 \\
.16 \\
.48 \\
.08 \\
.00\end{array}$ & $\begin{array}{l}.00 \\
.01 \\
.14 \\
.00 \\
.03 \\
.61\end{array}$ & $\begin{array}{l}.17 \\
.00 \\
.02 \\
-0 . \\
--\end{array}$ & $\begin{array}{l}.00 \\
.00 \\
.00 \\
.00 \\
.13 \\
.01\end{array}$ & $\begin{array}{l}.61 \\
.02 \\
.06 \\
.00 \\
.07 \\
-.-\end{array}$ & $\begin{array}{l}.29 \\
.21 \\
.00 \\
.00 \\
.00 \\
.00\end{array}$ & $\begin{array}{l}.01 \\
.00 \\
.00 \\
.00 \\
.00 \\
\end{array}$ & $\begin{array}{l}.14 \\
.00 \\
.00 \\
.00 \\
.00 \\
.00\end{array}$ & $\begin{array}{l}.02 \\
.01 \\
.01 \\
.01 \\
.00 \\
.00\end{array}$ & $\begin{array}{l}.00 \\
.00 \\
.00 \\
.00 \\
.05 \\
-.-\end{array}$ \\
\hline TOTAL & 3.75 & 7.61 & 12.83 & 6.34 & +.45 & 2.28 & 5.06 & 4.17 & 1.98 & 1.51 & 3.40 & 2.85 \\
\hline
\end{tabular}


TABLE 13-DAILY PRECIPITATION-Continued

STATION NUMBER 14211115 RAIN GAGE ON OAK LODGE RFPD NO. 4 IN OAK GROVE

LATITUDE 452457 LONGITUDE 1223753

RAINFALL (IN.), WA!ER YEAR OCTOBER 1977 TO SEPTEMBER 1978

\begin{tabular}{|c|c|c|c|c|c|c|c|c|c|c|c|c|}
\hline DAY & OCT & NOV & DEC & JAN & FEB & MAR & APR & MAY & JUN & JUL & AUG & SEP \\
\hline $\begin{array}{l}1 \\
2 \\
3 \\
4 \\
5\end{array}$ & $\begin{array}{l}.01 \\
.00 \\
.00 \\
.00 \\
.00\end{array}$ & $\begin{array}{l}.60 \\
.14 \\
.01 \\
.12 \\
.19\end{array}$ & $\begin{array}{r}.09 \\
2.21 \\
.20 \\
.05 \\
.03\end{array}$ & $\begin{array}{l}.33 \\
.06 \\
.42 \\
.31 \\
.68\end{array}$ & $\begin{array}{r}.57 \\
.34 \\
.02 \\
.00 \\
.20\end{array}$ & $\begin{array}{l}.00 \\
.00 \\
.05 \\
.14 \\
.00\end{array}$ & $\begin{array}{l}.07 \\
.28 \\
.05 \\
.15 \\
.37\end{array}$ & $\begin{array}{l}.00 \\
.00 \\
.00 \\
.11 \\
.00\end{array}$ & $\begin{array}{l}.00 \\
.00 \\
.00 \\
.00 \\
.00\end{array}$ & $\begin{array}{l}.00 \\
.20 \\
.02 \\
.00 \\
.00\end{array}$ & $\begin{array}{l}.00 \\
.00 \\
.00 \\
.00 \\
.00\end{array}$ & $\begin{array}{l}.01 \\
.01 \\
.40 \\
.13 \\
.17\end{array}$ \\
\hline $\begin{array}{r}6 \\
7 \\
8 \\
9 \\
10\end{array}$ & $\begin{array}{l}.35 \\
.36 \\
.01 \\
.00 \\
.00\end{array}$ & $\begin{array}{l}.11 \\
.15 \\
.02 \\
.00 \\
.00\end{array}$ & $\begin{array}{l}.81 \\
.01 \\
.01 \\
.21 \\
.48\end{array}$ & $\begin{array}{l}.06 \\
.25 \\
.36 \\
.09 \\
.03\end{array}$ & $\begin{array}{l}.19 \\
.76 \\
.18 \\
.03 \\
.00\end{array}$ & $\begin{array}{l}.03 \\
.39 \\
.05 \\
.00 \\
.00\end{array}$ & $\begin{array}{l}.01 \\
.00 \\
.00 \\
.00 \\
.00\end{array}$ & $\begin{array}{l}.00 \\
.00 \\
.00 \\
.02 \\
.17\end{array}$ & $\begin{array}{l}.00 \\
.00 \\
.00 \\
.15 \\
.18\end{array}$ & $\begin{array}{l}.00 \\
.00 \\
.00 \\
.00 \\
.00\end{array}$ & $\begin{array}{l}.00 \\
.00 \\
00 \\
.00 \\
.00\end{array}$ & $\begin{array}{l}.02 \\
.18 \\
.24 \\
.53 \\
.70\end{array}$ \\
\hline $\begin{array}{l}11 \\
12 \\
13 \\
14 \\
15\end{array}$ & $\begin{array}{l}.00 \\
.00 \\
.08 \\
.00 \\
.00\end{array}$ & $\begin{array}{l}.06 \\
.44 \\
.34 \\
.41 \\
.11\end{array}$ & $\begin{array}{r}1.29 \\
.77 \\
1.96 \\
.95 \\
.98\end{array}$ & $\begin{array}{l}.13 \\
.07 \\
.34 \\
.10 \\
.26\end{array}$ & $\begin{array}{l}.00 \\
.00 \\
.00 \\
.18 \\
.06\end{array}$ & $\begin{array}{l}.17 \\
.01 \\
.17 \\
.00 \\
.00\end{array}$ & $\begin{array}{l}.00 \\
.00 \\
.22 \\
.29 \\
.27\end{array}$ & $\begin{array}{r}.27 \\
.26 \\
1.24 \\
.97 \\
.10\end{array}$ & $\begin{array}{l}.01 \\
.16 \\
.19 \\
.36 \\
.02\end{array}$ & $\begin{array}{l}.00 \\
.00 \\
.00 \\
.00 \\
.74\end{array}$ & $\begin{array}{l}.00 \\
.55 \\
.09 \\
.00 \\
.74\end{array}$ & $\begin{array}{l}.01 \\
.01 \\
.17 \\
.01 \\
.01\end{array}$ \\
\hline $\begin{array}{l}16 \\
17 \\
18 \\
19 \\
20\end{array}$ & $\begin{array}{l}.00 \\
.00 \\
.00 \\
.00 \\
.00\end{array}$ & $\begin{array}{l}.01 \\
.21 \\
.15 \\
.01 \\
.15\end{array}$ & $\begin{array}{l}.36 \\
.08 \\
.10 \\
.02 \\
.00\end{array}$ & $\begin{array}{l}.36 \\
.19 \\
.53 \\
.07 \\
.01\end{array}$ & $\begin{array}{l}.03 \\
.00 \\
.15 \\
.01 \\
.00\end{array}$ & $\begin{array}{l}.00 \\
.00 \\
.00 \\
.00 \\
.00\end{array}$ & $\begin{array}{l}.24 \\
.29 \\
.06 \\
.34 \\
.11\end{array}$ & $\begin{array}{l}.00 \\
.01 \\
.01 \\
.00 \\
.00\end{array}$ & $\begin{array}{l}.00 \\
.00 \\
.00 \\
.00 \\
.00\end{array}$ & $\begin{array}{l}.28 \\
.00 \\
.00 \\
.00 \\
.00\end{array}$ & $\begin{array}{l}.23 \\
.01 \\
.00 \\
.05 \\
.51\end{array}$ & $\begin{array}{l}.01 \\
.31 \\
.02 \\
.00 \\
.04\end{array}$ \\
\hline $\begin{array}{l}21 \\
22 \\
23 \\
24 \\
25\end{array}$ & $\begin{array}{r}.00 \\
.00 \\
.29 \\
.70 \\
.37\end{array}$ & $\begin{array}{r}.05 \\
.50 \\
.85 \\
.92 \\
1.12\end{array}$ & $\begin{array}{l}.00 \\
.03 \\
.13 \\
.23 \\
.00\end{array}$ & $\begin{array}{l}.44 \\
.00 \\
.00 \\
.00 \\
.12\end{array}$ & $\begin{array}{l}.00 \\
.00 \\
.01 \\
.25 \\
.40\end{array}$ & $\begin{array}{l}.00 \\
.00 \\
.41 \\
.25 \\
.05\end{array}$ & $\begin{array}{l}.56 \\
.46 \\
.00 \\
.00 \\
.27\end{array}$ & $\begin{array}{l}.00 \\
.04 \\
.01 \\
.14 \\
.00\end{array}$ & $\begin{array}{l}.00 \\
.00 \\
.22 \\
.00 \\
.00\end{array}$ & $\begin{array}{l}.00 \\
.00 \\
.00 \\
.00 \\
.00\end{array}$ & $\begin{array}{l}.02 \\
.02 \\
.16 \\
.48 \\
.09\end{array}$ & $\begin{array}{l}.01 \\
.00 \\
.01 \\
.00 \\
.00\end{array}$ \\
\hline $\begin{array}{l}26 \\
27 \\
28 \\
29 \\
30 \\
31\end{array}$ & $\begin{array}{l}.02 \\
.01 \\
.47 \\
.95 \\
.17 \\
.10\end{array}$ & $\begin{array}{r}.00 \\
.30 \\
.10 \\
.20 \\
.00 \\
-\end{array}$ & $\begin{array}{l}.00 \\
.00 \\
.13 \\
.49 \\
.07 \\
.00\end{array}$ & $\begin{array}{l}.00 \\
.08 \\
.00 \\
.00 \\
.00 \\
.59\end{array}$ & \begin{tabular}{l}
.15 \\
00 \\
000 \\
-0. \\
\hdashline-0
\end{tabular} & $\begin{array}{l}.00 \\
.00 \\
.00 \\
.00 \\
.11 \\
.00\end{array}$ & $\begin{array}{l}.59 \\
.03 \\
.25 \\
.00 \\
.06 \\
-.-\end{array}$ & $\begin{array}{l}.29 \\
.20 \\
.00 \\
.00 \\
.00 \\
.00\end{array}$ & $\begin{array}{l}.00 \\
.00 \\
.00 \\
.00 \\
.00 \\
-0\end{array}$ & $\begin{array}{l}.10 \\
.00 \\
.00 \\
.00 \\
.00 \\
.00\end{array}$ & $\begin{array}{l}.03 \\
.01 \\
.03 \\
.01 \\
.00 \\
.00\end{array}$ & $\begin{array}{l}.00 \\
.00 \\
.00 \\
.00 \\
.03 \\
-.0\end{array}$ \\
\hline TOTAL & 3.81 & 7.27 & 11,69 & 5.88 & 3.53 & 1.83 & 4.87 & 3.84 & 1.29 & 1.34 & 3.03 & 3.03 \\
\hline
\end{tabular}

WTR YR 1978 TOTAI 51.41

STATION NUMBER 14211125 RAIN GAGE ON BILOUEST SCHOOL NR CLACKAMAS

LATITUDE 452434 LONGITUDE 1223518

RAINFALL (IN.). WATER YEAR OCTOBER 1977 TO SEPTEMBER $197 \%$

\begin{tabular}{|c|c|c|c|c|c|c|c|c|c|c|c|c|}
\hline DAY & OCT & NOV & DEC & JAN & FEB & MAR & APR & MAY & JUN & JULL & AUG & SEP \\
\hline $\begin{array}{l}1 \\
2 \\
3 \\
4 \\
5\end{array}$ & $\begin{array}{l}.00 \\
.00 \\
.00 \\
.00 \\
.00\end{array}$ & $\begin{array}{l}.59 \\
.18 \\
.06 \\
.14 \\
.18\end{array}$ & $\begin{array}{r}.06 \\
2.04 \\
.23 \\
.31 \\
.03\end{array}$ & $\begin{array}{l}.18 \\
.04 \\
.69 \\
.09 \\
.67\end{array}$ & $\begin{array}{l}.00 \\
.00 \\
.03 \\
.00 \\
.22\end{array}$ & $\begin{array}{l}.00 \\
.00 \\
.10 \\
.15 \\
.02\end{array}$ & $\begin{array}{l}.07 \\
.31 \\
.04 \\
.13 \\
.27\end{array}$ & $\begin{array}{l}.01 \\
.00 \\
.00 \\
.11 \\
.01\end{array}$ & $\begin{array}{l}.00 \\
.00 \\
.00 \\
.00 \\
.00\end{array}$ & $\begin{array}{l}.00 \\
.13 \\
.02 \\
.00 \\
.0 C\end{array}$ & $\begin{array}{l}.00 \\
.00 \\
.00 \\
.00 \\
.00\end{array}$ & $\begin{array}{l}.00 \\
.01 \\
.31 \\
.10 \\
.17\end{array}$ \\
\hline $\begin{array}{r}6 \\
7 \\
8 \\
9 \\
10\end{array}$ & $\begin{array}{l}.42 \\
.20 \\
.00 \\
.00 \\
.00\end{array}$ & $\begin{array}{l}.06 \\
.16 \\
.02 \\
.00 \\
.01\end{array}$ & $\begin{array}{r}1.00 \\
.43 \\
.06 \\
.77 \\
.54\end{array}$ & $\begin{array}{l}.03 \\
.41 \\
.22 \\
.13 \\
.05\end{array}$ & $\begin{array}{l}.25 \\
.70 \\
.17 \\
.06 \\
.00\end{array}$ & $\begin{array}{l}.04 \\
.38 \\
.08 \\
.00 \\
.00\end{array}$ & $\begin{array}{l}.01 \\
.00 \\
.00 \\
.00 \\
.00\end{array}$ & $\begin{array}{l}.00 \\
.00 \\
.00 \\
.06 \\
.16\end{array}$ & $\begin{array}{l}.00 \\
.00 \\
.00 \\
.22 \\
.27\end{array}$ & $\begin{array}{l}.00 \\
.00 \\
.00 \\
.00 \\
.00\end{array}$ & $\begin{array}{l}.00 \\
.00 \\
.00 \\
.00 \\
.00\end{array}$ & $\begin{array}{l}.01 \\
.11 \\
.25 \\
.42 \\
.59\end{array}$ \\
\hline $\begin{array}{l}11 \\
12 \\
13 \\
14 \\
15\end{array}$ & $\begin{array}{l}.00 \\
.00 \\
.03 \\
.00 \\
.00\end{array}$ & $\begin{array}{r}.05 \\
.35 \\
.32 \\
.35 \\
.15\end{array}$ & $\begin{array}{r}1.48 \\
.72 \\
1.74 \\
.44 \\
.61\end{array}$ & $\begin{array}{l}.15 \\
.09 \\
.36 \\
.13 \\
.21\end{array}$ & $\begin{array}{l}.01 \\
.05 \\
.00 \\
.19 \\
.09\end{array}$ & $\begin{array}{l}.24 \\
.01 \\
.15 \\
.00 \\
.00\end{array}$ & $\begin{array}{l}.00 \\
.00 \\
.18 \\
.34 \\
.33\end{array}$ & $\begin{array}{r}.20 \\
.26 \\
1.42 \\
1.06 \\
.11\end{array}$ & $\begin{array}{l}.00 \\
.12 \\
.30 \\
.58 \\
.00\end{array}$ & $\begin{array}{l}.00 \\
.00 \\
.00 \\
.00 \\
.05\end{array}$ & $\begin{array}{l}.00 \\
.28 \\
.11 \\
.00 \\
.77\end{array}$ & $\begin{array}{l}.00 \\
.02 \\
.14 \\
.03 \\
.01\end{array}$ \\
\hline $\begin{array}{l}16 \\
17 \\
18 \\
19 \\
20\end{array}$ & $\begin{array}{l}.00 \\
.00 \\
.00 \\
.00 \\
.00\end{array}$ & $\begin{array}{l}.01 \\
.18 \\
.14 \\
.01 \\
.04\end{array}$ & $\begin{array}{l}.47 \\
.40 \\
.10 \\
.08 \\
.01\end{array}$ & $\begin{array}{l}.46 \\
.16 \\
.56 \\
.01 \\
.17\end{array}$ & $\begin{array}{l}.03 \\
.01 \\
.16 \\
.02 \\
.00\end{array}$ & $\begin{array}{l}.00 \\
.00 \\
.00 \\
.00 \\
.00\end{array}$ & $\begin{array}{l}.14 \\
.30 \\
.14 \\
.37 \\
.15\end{array}$ & $\begin{array}{l}.01 \\
.00 \\
.01 \\
.00 \\
.00\end{array}$ & $\begin{array}{l}.00 \\
.00 \\
.00 \\
.00 \\
.00\end{array}$ & $\begin{array}{l}.28 \\
.00 \\
.00 \\
.00 \\
.00\end{array}$ & $\begin{array}{l}.32 \\
.00 \\
.00 \\
.04 \\
.56\end{array}$ & $\begin{array}{l}.01 \\
.21 \\
.02 \\
.00 \\
.02\end{array}$ \\
\hline $\begin{array}{l}21 \\
22 \\
23 \\
24 \\
25\end{array}$ & $\begin{array}{l}.00 \\
.00 \\
.33 \\
.74 \\
.33\end{array}$ & $\begin{array}{l}.04 \\
.55 \\
.97 \\
.89 \\
.94\end{array}$ & $\begin{array}{l}.00 \\
.05 \\
.15 \\
.28 \\
.00\end{array}$ & $\begin{array}{l}.45 \\
.00 \\
.00 \\
.00 \\
.15\end{array}$ & $\begin{array}{l}.00 \\
.01 \\
.03 \\
.28 \\
.60\end{array}$ & $\begin{array}{l}.00 \\
.00 \\
.38 \\
.24 \\
.02\end{array}$ & $\begin{array}{l}.34 \\
.41 \\
.00 \\
.01 \\
.28\end{array}$ & $\begin{array}{l}.00 \\
.00 \\
.01 \\
.08 \\
.00\end{array}$ & $\begin{array}{l}.00 \\
.00 \\
.21 \\
.00 \\
.00\end{array}$ & $\begin{array}{l}.00 \\
.00 \\
.00 \\
.00 \\
.00\end{array}$ & $\begin{array}{l}.02 \\
.05 \\
.12 \\
.45 \\
.07\end{array}$ & $\begin{array}{l}.00 \\
.02 \\
.01 \\
.00 \\
.00\end{array}$ \\
\hline $\begin{array}{l}26 \\
27 \\
28 \\
29 \\
30 \\
31\end{array}$ & $\begin{array}{l}.01 \\
.01 \\
.32 \\
.79 \\
.18 \\
.09\end{array}$ & $\begin{array}{l}.00 \\
.25 \\
.06 \\
.24 \\
.00 \\
.\end{array}$ & $\begin{array}{l}.00 \\
.07 \\
.47 \\
.32 \\
.03 \\
.00\end{array}$ & $\begin{array}{l}.00 \\
.00 \\
.10 \\
.00 \\
.00 \\
.60\end{array}$ & $\begin{array}{l}18 \\
.00 \\
.00 \\
0.0 \\
\end{array}$ & $\begin{array}{l}.00 \\
.00 \\
.00 \\
.00 \\
.11 \\
.00\end{array}$ & $\begin{array}{l}.04 \\
.09 \\
.11 \\
.01 \\
.05 \\
-.0\end{array}$ & $\begin{array}{l}.24 \\
.23 \\
.00 \\
.00 \\
.00 \\
.00\end{array}$ & $\begin{array}{l}.00 \\
.00 \\
.00 \\
.00 \\
.00 \\
.00\end{array}$ & $\begin{array}{l}.15 \\
.00 \\
.00 \\
.00 \\
.00 \\
.00\end{array}$ & $\begin{array}{l}.02 \\
.00 \\
.00 \\
.00 \\
.00 \\
.00\end{array}$ & $\begin{array}{l}.01 \\
.00 \\
.00 \\
.00 \\
.00 \\
-0 .\end{array}$ \\
\hline TOTAL & 3.45 & 6.94 & 12.89 & 6.03 & 3.09 & 1.92 & 4.72 & 3.98 & 1.70 & 1.43 & 2.81 & 2.47 \\
\hline
\end{tabular}

WTR YR 1978 TOTAL 51.43 
TABLE 13.-DAILY PRECIPITATION-Continued

STATION NUMBER 14211301 TRYON CREEK TRIB AT OOLPH CT AT PORTLANO,OREG.

LATITUDE 452743 LONGITUDE 1224218

RAINFALL (IN,), WAIER YEAR OCTOBER 1977 TO SEPTEMBER 1978

\begin{tabular}{|c|c|c|c|c|c|c|c|c|c|c|c|c|}
\hline DAY & $\mathrm{OCT}$ & NOV & DEC & JAN & FEB & MAR & APR & MAY & JUN & JUL & AUG & SEP \\
\hline $\begin{array}{l}1 \\
2 \\
3 \\
4 \\
5\end{array}$ & $\begin{array}{l}.00 \\
.00 \\
.00 \\
.00 \\
.00\end{array}$ & $\begin{array}{l}.42 \\
.10 \\
.01 \\
.11 \\
.17\end{array}$ & $\begin{array}{r}.03 \\
1.97 \\
.03 \\
.13 \\
.03\end{array}$ & $\begin{array}{l}.14 \\
.00 \\
.00 \\
.06 \\
.46\end{array}$ & $\begin{array}{l}.65 \\
.31 \\
.03 \\
.00 \\
.30\end{array}$ & $\begin{array}{l}.00 \\
.00 \\
.11 \\
.17 \\
.00\end{array}$ & $\begin{array}{l}.08 \\
.26 \\
.06 \\
.37 \\
.38\end{array}$ & $\begin{array}{l}.00 \\
.00 \\
.00 \\
.08 \\
.00\end{array}$ & $\begin{array}{l}.00 \\
.00 \\
.00 \\
.00 \\
.00\end{array}$ & $\begin{array}{l}.00 \\
.12 \\
.04 \\
.00 \\
.00\end{array}$ & $\begin{array}{l}.00 \\
.00 \\
.00 \\
.00 \\
.00\end{array}$ & $\begin{array}{l}.00 \\
.00 \\
.40 \\
.10 \\
.10\end{array}$ \\
\hline $\begin{array}{r}6 \\
7 \\
8 \\
9 \\
10\end{array}$ & $\begin{array}{l}.28 \\
.51 \\
.00 \\
.00 \\
.00\end{array}$ & $\begin{array}{l}.16 \\
.09 \\
.01 \\
.00 \\
.00\end{array}$ & $\begin{array}{l}.24 \\
.04 \\
.01 \\
.29 \\
.47\end{array}$ & $\begin{array}{l}.04 \\
.29 \\
.38 \\
.33 \\
.02\end{array}$ & $\begin{array}{l}.12 \\
.62 \\
.31 \\
.13 \\
.00\end{array}$ & $\begin{array}{l}.09 \\
.49 \\
.10 \\
.00 \\
.00\end{array}$ & $\begin{array}{l}.00 \\
.01 \\
.00 \\
.00 \\
.00\end{array}$ & $\begin{array}{l}.00 \\
.00 \\
.00 \\
.05 \\
.13\end{array}$ & $\begin{array}{l}.00 \\
.00 \\
.00 \\
.21 \\
.22\end{array}$ & $\begin{array}{l}.00 \\
.00 \\
.00 \\
.00 \\
.00\end{array}$ & $\begin{array}{l}.00 \\
.00 \\
.00 \\
.00 \\
.00\end{array}$ & $\begin{array}{l}.00 \\
.20 \\
.20 \\
.70 \\
.70\end{array}$ \\
\hline $\begin{array}{l}11 \\
12 \\
13 \\
14 \\
15\end{array}$ & $\begin{array}{l}.00 \\
.00 \\
.00 \\
.00 \\
.00\end{array}$ & $\begin{array}{l}.11 \\
.45 \\
.21 \\
.31 \\
.08\end{array}$ & $\begin{array}{r}1.11 \\
.96 \\
2.40 \\
: 99 \\
.98\end{array}$ & $\begin{array}{l}.10 \\
.07 \\
.39 \\
.12 \\
.18\end{array}$ & $\begin{array}{l}.00 \\
.01 \\
.00 \\
.30 \\
.07\end{array}$ & $\begin{array}{l}.22 \\
.05 \\
.19 \\
.00 \\
.02\end{array}$ & $\begin{array}{l}.00 \\
.00 \\
.29 \\
.22 \\
.28\end{array}$ & $\begin{array}{r}.51 \\
.21 \\
1.24 \\
.87 \\
.31\end{array}$ & $\begin{array}{l}.01 \\
.17 \\
.20 \\
.41 \\
.02\end{array}$ & $\begin{array}{l}.00 \\
.00 \\
.00 \\
.00 \\
.70\end{array}$ & $\begin{array}{l}.00 \\
.55 \\
.05 \\
.00 \\
.85\end{array}$ & $\begin{array}{l}.00 \\
.00 \\
.20 \\
.00 \\
.00\end{array}$ \\
\hline $\begin{array}{l}16 \\
17 \\
18 \\
19 \\
20\end{array}$ & $\begin{array}{l}.00 \\
.00 \\
.00 \\
.00 \\
.00\end{array}$ & $\begin{array}{l}.05 \\
.17 \\
.29 \\
.01 \\
.15\end{array}$ & $\begin{array}{l}.48 \\
.03 \\
.05 \\
.00 \\
.00\end{array}$ & $\begin{array}{l}.45 \\
.33 \\
.27 \\
.28 \\
.09\end{array}$ & $\begin{array}{l}.09 \\
.01 \\
.00 \\
.01 \\
.00\end{array}$ & $\begin{array}{l}.00 \\
.00 \\
.00 \\
.00 \\
.00\end{array}$ & $\begin{array}{l}.05 \\
.32 \\
.23 \\
.27 \\
.33\end{array}$ & $\begin{array}{l}.00 \\
.00 \\
.01 \\
.00 \\
.00\end{array}$ & $\begin{array}{l}.00 \\
.00 \\
.00 \\
.00 \\
.00\end{array}$ & $\begin{array}{l}.22 \\
.00 \\
.00 \\
.00 \\
.00\end{array}$ & $\begin{array}{l}.02 \\
.00 \\
.00 \\
.05 \\
.50\end{array}$ & $\begin{array}{l}.05 \\
.30 \\
.00 \\
.00 \\
.05\end{array}$ \\
\hline $\begin{array}{l}26 \\
27 \\
28 \\
29 \\
30 \\
31\end{array}$ & $\begin{array}{l}.01 \\
.01 \\
.36 \\
.67 \\
.18 \\
.09\end{array}$ & $\begin{array}{l}.00 \\
.16 \\
.20 \\
.10 \\
.00 \\
-\end{array}$ & $\begin{array}{l}.00 \\
.02 \\
.35 \\
.28 \\
.06 \\
.00\end{array}$ & $\begin{array}{l}.01 \\
.01 \\
.11 \\
.00 \\
.00 \\
.57\end{array}$ & \begin{tabular}{r}
.10 \\
.00 \\
.00 \\
\hdashline-0 \\
-0
\end{tabular} & $\begin{array}{l}.00 \\
.00 \\
.00 \\
.00 \\
.10 \\
.02\end{array}$ & $\begin{array}{l}.48 \\
.09 \\
.11 \\
.00 \\
.08 \\
-.-\end{array}$ & $\begin{array}{l}.27 \\
.20 \\
.00 \\
.00 \\
.00 \\
.00\end{array}$ & $\begin{array}{l}.01 \\
.00 \\
.00 \\
.00 \\
.00 \\
-.0\end{array}$ & $\begin{array}{l}.00 \\
.00 \\
.00 \\
.00 \\
.00 \\
.00\end{array}$ & $\begin{array}{l}.00 \\
.00 \\
.00 \\
.00 \\
.00 \\
.00\end{array}$ & $\begin{array}{l}.00 \\
.00 \\
.00 \\
.00 \\
.05 \\
-\cdots\end{array}$ \\
\hline TOTAL & 3.35 & 6.52 & 11.29 & 5.46 & 3.98 & 2.24 & 4.93 & 4.43 & 1.47 & 1.08 & 2.62 & 3.05 \\
\hline
\end{tabular}

WTR YR 1978 TOTAL. 50.42

STATION NUMBER
LATITUOE
452926
LONGITUDE I 1222522

RAINFALL (IN.), WATER YEAR OCTOBEH 1977 TO SEPTEMBER 1978

\begin{tabular}{|c|c|c|c|c|c|c|c|c|c|c|c|c|}
\hline DAY & OCT & NOV & DEC & JAN & FEB & MAF & $A P R$ & MAY & JUN & JUL & AUL & SEP \\
\hline $\begin{array}{l}1 \\
2 \\
3 \\
4 \\
5\end{array}$ & $\begin{array}{l}.01 \\
.00 \\
.00 \\
.00 \\
.00\end{array}$ & $\begin{array}{l}.59 \\
.04 \\
.01 \\
.22 \\
.15\end{array}$ & $\begin{array}{r}.10 \\
2.62 \\
.47 \\
.23 \\
.22\end{array}$ & $\begin{array}{l}.01 \\
.00 \\
.01 \\
.51 \\
.11\end{array}$ & $\begin{array}{l}.02 \\
.36 \\
.05 \\
.00 \\
.33\end{array}$ & $\begin{array}{l}.00 \\
.00 \\
.08 \\
.16 \\
.00\end{array}$ & $\begin{array}{l}.05 \\
.17 \\
.15 \\
.29 \\
.23\end{array}$ & $\begin{array}{l}.00 \\
.00 \\
.00 \\
.32 \\
.00\end{array}$ & $\begin{array}{l}.00 \\
.00 \\
.00 \\
.00 \\
.00\end{array}$ & $\begin{array}{l}.12 \\
.04 \\
.03 \\
.00 \\
.00\end{array}$ & $\begin{array}{l}.00 \\
.00 \\
.00 \\
.00 \\
.00\end{array}$ & $\begin{array}{l}.00 \\
.01 \\
.75 \\
.25 \\
.25\end{array}$ \\
\hline $\begin{array}{r}6 \\
7 \\
8 \\
9 \\
10\end{array}$ & $\begin{array}{l}.37 \\
.31 \\
.00 \\
.00 \\
.00\end{array}$ & $\begin{array}{l}.12 \\
.08 \\
.02 \\
.00 \\
.01\end{array}$ & $\begin{array}{l}.74 \\
.06 \\
.00 \\
.19 \\
.49\end{array}$ & $\begin{array}{l}.00 \\
.17 \\
.33 \\
.16 \\
.05\end{array}$ & $\begin{array}{r}.32 \\
.82 \\
.19 \\
.10 \\
.01\end{array}$ & $\begin{array}{l}.02 \\
.50 \\
.07 \\
.00 \\
.01\end{array}$ & $\begin{array}{r}.00 \\
.00 \\
.00 \\
.00 \\
.00\end{array}$ & $\begin{array}{l}.01 \\
.00 \\
.00 \\
.08 \\
.23\end{array}$ & $\begin{array}{l}.00 \\
.00 \\
.00 \\
.35 \\
.23\end{array}$ & $\begin{array}{l}.00 \\
.00 \\
.00 \\
.00 \\
.00\end{array}$ & $\begin{array}{l}.00 \\
.00 \\
.00 \\
.00 \\
.00\end{array}$ & $\begin{array}{l}.05 \\
.08 \\
.22 \\
.21 \\
.53\end{array}$ \\
\hline $\begin{array}{l}11 \\
12 \\
13 \\
14 \\
15\end{array}$ & $\begin{array}{l}.00 \\
.00 \\
.06 \\
.00 \\
.00\end{array}$ & $\begin{array}{l}.08 \\
.30 \\
.55 \\
.80 \\
.20\end{array}$ & $\begin{array}{r}1.73 \\
.99 \\
2.21 \\
1.04 \\
.66\end{array}$ & $\begin{array}{l}.17 \\
.08 \\
.29 \\
.21 \\
.22\end{array}$ & $\begin{array}{l}.00 \\
.03 \\
.00 \\
.27 \\
.42\end{array}$ & $\begin{array}{l}.26 \\
.01 \\
.30 \\
.00 \\
.00\end{array}$ & $\begin{array}{l}.00 \\
.00 \\
.16 \\
.42 \\
.44\end{array}$ & $\begin{array}{r}.43 \\
.32 \\
1.15 \\
1.16 \\
.34\end{array}$ & $\begin{array}{l}.01 \\
.17 \\
.37 \\
.76 \\
.01\end{array}$ & $\begin{array}{l}.00 \\
.00 \\
.00 \\
.00 \\
.98\end{array}$ & $\begin{array}{l}.00 \\
.77 \\
.09 \\
.00 \\
.79\end{array}$ & $\begin{array}{r}.05 \\
.00 \\
.19 \\
.07 \\
.04\end{array}$ \\
\hline $\begin{array}{l}16 \\
17 \\
18 \\
19 \\
20\end{array}$ & $\begin{array}{l}.00 \\
.00 \\
.00 \\
.00 \\
.00\end{array}$ & $\begin{array}{l}.02 \\
.25 \\
.20 \\
.20 \\
.00\end{array}$ & $\begin{array}{l}.36 \\
.17 \\
.10 \\
.01 \\
.00\end{array}$ & $\begin{array}{l}.44 \\
.26 \\
.50 \\
.07 \\
.15\end{array}$ & $\begin{array}{l}.03 \\
.02 \\
.02 \\
.01 \\
.00\end{array}$ & $\begin{array}{l}.00 \\
.00 \\
.00 \\
.00 \\
.00\end{array}$ & $\begin{array}{l}.26 \\
.47 \\
.08 \\
.45 \\
.25\end{array}$ & $\begin{array}{l}.01 \\
.00 \\
.00 \\
.00 \\
.00\end{array}$ & $\begin{array}{l}.01 \\
.00 \\
.00 \\
.00 \\
.00\end{array}$ & $\begin{array}{l}.47 \\
.00 \\
.00 \\
.00 \\
.00\end{array}$ & $\begin{array}{l}.72 \\
.01 \\
.00 \\
.05 \\
.45\end{array}$ & $\begin{array}{l}.21 \\
.07 \\
.00 \\
.00 \\
.01\end{array}$ \\
\hline $\begin{array}{l}21 \\
22 \\
23 \\
24 \\
25\end{array}$ & $\begin{array}{l}.00 \\
.00 \\
.23 \\
.67 \\
.46\end{array}$ & $\begin{array}{l}.08 \\
.80 \\
.80 \\
.70 \\
.90\end{array}$ & $\begin{array}{l}.00 \\
.02 \\
.23 \\
.38 \\
.01\end{array}$ & $\begin{array}{l}.55 \\
.03 \\
.00 \\
.00 \\
.25\end{array}$ & $\begin{array}{l}.00 \\
.00 \\
.05 \\
.36 \\
.82\end{array}$ & $\begin{array}{l}.00 \\
.00 \\
.26 \\
.15 \\
.09\end{array}$ & $\begin{array}{l}.59 \\
.42 \\
.00 \\
.01 \\
.22\end{array}$ & $\begin{array}{r}.00 \\
.11 \\
.03 \\
.11 \\
.03\end{array}$ & $\begin{array}{l}.00 \\
.00 \\
.13 \\
.05 \\
.01\end{array}$ & $\begin{array}{l}.00 \\
.00 \\
.00 \\
.00 \\
.00\end{array}$ & $\begin{array}{l}.05 \\
.06 \\
.09 \\
.36 \\
.07\end{array}$ & $\begin{array}{l}.01 \\
.06 \\
.00 \\
.00 \\
.00\end{array}$ \\
\hline $\begin{array}{l}26 \\
27 \\
28 \\
29 \\
30 \\
31\end{array}$ & $\begin{array}{l}.01 \\
.00 \\
.30 \\
.70 \\
.18 \\
.13\end{array}$ & $\begin{array}{l}.00 \\
.50 \\
.10 \\
.25 \\
.00 \\
-.0\end{array}$ & $\begin{array}{l}.01 \\
.03 \\
.12 \\
.24 \\
.00 \\
.00\end{array}$ & $\begin{array}{l}.01 \\
.00 \\
.11 \\
.01 \\
.00 \\
.88\end{array}$ & $\begin{array}{l}.16 \\
.00 \\
.00 \\
-0 . \\
-0 .\end{array}$ & $\begin{array}{l}.00 \\
.18 \\
.00 \\
.13 \\
.00 \\
.00\end{array}$ & $\begin{array}{l}.62 \\
.23 \\
.03 \\
.00 \\
.07 \\
. .-\end{array}$ & $\begin{array}{l}.27 \\
.28 \\
.00 \\
.00 \\
.00 \\
.00\end{array}$ & $\begin{array}{r}.00 \\
.11 \\
.01 \\
.00 \\
.00 \\
.0\end{array}$ & $\begin{array}{l}.08 \\
.00 \\
.00 \\
.00 \\
.00 \\
.00\end{array}$ & $\begin{array}{l}.00 \\
.00 \\
.01 \\
.00 \\
.00 \\
.00\end{array}$ & $\begin{array}{l}.00 \\
.00 \\
.00 \\
.01 \\
.04 \\
.0\end{array}$ \\
\hline TOTAL & 3.43 & 8.17 & 13.43 & 5.58 & 4.99 & 2.22 & 5.61 & 4.88 & 2.22 & 1.72 & 3.52 & 2.61 \\
\hline
\end{tabular}


STATION NUMBER 14211800 SALTZMAN CREEK AT PORTLAND,OKEG.

LATITUDE 453354 LONGITUDE 1224438

RAINFALL (IN.), WATER YEAR OCTU8ER 1977 TO SEPTEMBER 1978

\begin{tabular}{|c|c|c|c|c|c|c|c|c|c|c|c|c|c|}
\hline DAY & OCT & NOV & DEC & SAN & FEB & MAR & APR & MAY & JUN & JUL & AUG & & SEP \\
\hline $\begin{array}{l}1 \\
2 \\
3 \\
4 \\
5\end{array}$ & $\begin{array}{l}.01 \\
.00 \\
.01 \\
.00 \\
.00\end{array}$ & $\begin{array}{l}.35 \\
.08 \\
.00 \\
.12 \\
.22\end{array}$ & $\begin{array}{r}.05 \\
1.77 \\
.05 \\
.12 \\
.12\end{array}$ & $\begin{array}{l}.00 \\
.15 \\
.26 \\
.00 \\
.55\end{array}$ & $\begin{array}{l}.60 \\
.31 \\
.04 \\
.00 \\
.29\end{array}$ & $\begin{array}{l}.00 \\
.00 \\
.11 \\
.10 \\
.00\end{array}$ & $\begin{array}{l}.06 \\
.11 \\
.11 \\
.30 \\
.25\end{array}$ & $\begin{array}{l}.01 \\
.00 \\
.00 \\
.22 \\
.00\end{array}$ & $\begin{array}{l}.00 \\
.00 \\
.00 \\
.00 \\
.00\end{array}$ & $\begin{array}{l}.00 \\
.13 \\
.02 \\
.00 \\
.01\end{array}$ & $\begin{array}{l}.00 \\
.00 \\
.00 \\
.00 \\
.00\end{array}$ & & $\begin{array}{l}.00 \\
.00 \\
.44 \\
.09 \\
.08\end{array}$ \\
\hline $\begin{array}{r}6 \\
7 \\
8 \\
9 \\
10\end{array}$ & $\begin{array}{l}.28 \\
.41 \\
.00 \\
.00 \\
.00\end{array}$ & $\begin{array}{l}.15 \\
.09 \\
.00 \\
.03 \\
.04\end{array}$ & $\begin{array}{l}.28 \\
.16 \\
.00 \\
.26 \\
.57\end{array}$ & $\begin{array}{r}.03 \\
.27 \\
.35 \\
.45 \\
.02\end{array}$ & $\begin{array}{l}.23 \\
.72 \\
.20 \\
.04 \\
.00\end{array}$ & $\begin{array}{l}.07 \\
.62 \\
.02 \\
.00 \\
.00\end{array}$ & $\begin{array}{l}.00 \\
.00 \\
.00 \\
.00 \\
.00\end{array}$ & $\begin{array}{l}.00 \\
.00 \\
.00 \\
.03 \\
.09\end{array}$ & $\begin{array}{l}.00 \\
.00 \\
.00 \\
.26 \\
.40\end{array}$ & $\begin{array}{l}.00 \\
.00 \\
.00 \\
.00 \\
.00\end{array}$ & $\begin{array}{l}.00 \\
.00 \\
.00 \\
.02 \\
.00\end{array}$ & & $\begin{array}{r}.01 \\
.10 \\
.30 \\
.91 \\
.39\end{array}$ \\
\hline $\begin{array}{l}11 \\
12 \\
13 \\
14 \\
15\end{array}$ & $\begin{array}{l}.00 \\
.00 \\
.00 \\
.00 \\
.00\end{array}$ & $\begin{array}{l}.09 \\
.40 \\
.22 \\
.44 \\
.11\end{array}$ & $\begin{array}{r}.71 \\
.92 \\
2.22 \\
.64 \\
1.15\end{array}$ & $\begin{array}{l}.12 \\
.01 \\
.35 \\
.20 \\
.25\end{array}$ & $\begin{array}{l}.00 \\
.00 \\
.00 \\
.33 \\
.13\end{array}$ & $\begin{array}{l}.14 \\
.03 \\
.13 \\
.00 \\
.00\end{array}$ & $\begin{array}{l}.00 \\
.00 \\
.30 \\
.25 \\
.35\end{array}$ & $\begin{array}{r}.25 \\
.32 \\
1.33 \\
.89 \\
.12\end{array}$ & $\begin{array}{l}.00 \\
.08 \\
.08 \\
.23 \\
.02\end{array}$ & $\begin{array}{l}.00 \\
.00 \\
.00 \\
.00 \\
.95\end{array}$ & $\begin{array}{l}.00 \\
.04 \\
.02 \\
.00 \\
.36\end{array}$ & & $\begin{array}{l}.04 \\
.01 \\
.24 \\
.01 \\
.00\end{array}$ \\
\hline $\begin{array}{l}16 \\
17 \\
18 \\
19 \\
20\end{array}$ & $\begin{array}{l}.00 \\
.00 \\
.00 \\
.00 \\
.00\end{array}$ & $\begin{array}{l}.13 \\
.32 \\
.05 \\
.00 \\
.01\end{array}$ & $\begin{array}{r}.53 \\
.37 \\
.10 \\
.00 \\
.00\end{array}$ & $\begin{array}{l}.27 \\
.28 \\
.40 \\
.07 \\
.07\end{array}$ & $\begin{array}{l}.03 \\
.01 \\
.00 \\
.01 \\
.00\end{array}$ & $\begin{array}{l}.00 \\
.00 \\
.00 \\
.00 \\
.00\end{array}$ & $\begin{array}{l}.30 \\
.33 \\
.28 \\
.28 \\
.04\end{array}$ & $\begin{array}{l}.00 \\
.00 \\
.01 \\
.00 \\
.00\end{array}$ & $\begin{array}{l}.01 \\
.00 \\
.00 \\
.00 \\
.00\end{array}$ & $\begin{array}{l}.30 \\
.00 \\
.00 \\
.00 \\
.00\end{array}$ & $\begin{array}{l}.37 \\
.02 \\
.01 \\
.07 \\
.58\end{array}$ & & $\begin{array}{l}.00 \\
.22 \\
.01 \\
.00 \\
.07\end{array}$ \\
\hline $\begin{array}{l}21 \\
22 \\
23 \\
24 \\
25\end{array}$ & $\begin{array}{l}.00 \\
.00 \\
.06 \\
.38 \\
.19\end{array}$ & $\begin{array}{r}.00 \\
.50 \\
.66 \\
.71 \\
1.14\end{array}$ & $\begin{array}{l}.00 \\
.00 \\
.20 \\
.10 \\
.00\end{array}$ & $\begin{array}{l}.47 \\
.02 \\
.00 \\
.00 \\
.18\end{array}$ & $\begin{array}{l}.00 \\
.00 \\
.01 \\
.24 \\
.70\end{array}$ & $\begin{array}{l}.00 \\
.00 \\
.41 \\
.21 \\
.07\end{array}$ & $\begin{array}{l}.24 \\
.27 \\
.00 \\
.01 \\
.11\end{array}$ & $\begin{array}{l}.00 \\
.52 \\
.03 \\
.00 \\
.00\end{array}$ & $\begin{array}{l}.00 \\
.00 \\
.06 \\
.00 \\
.00\end{array}$ & $\begin{array}{l}.00 \\
.00 \\
.00 \\
.00 \\
.00\end{array}$ & $\begin{array}{l}.02 \\
.07 \\
.12 \\
.21 \\
.13\end{array}$ & & $\begin{array}{l}.00 \\
.02 \\
.00 \\
.00 \\
.00\end{array}$ \\
\hline $\begin{array}{l}26 \\
27 \\
28 \\
29 \\
30 \\
31\end{array}$ & $\begin{array}{l}.01 \\
.00 \\
.31 \\
.63 \\
.39 \\
.09\end{array}$ & $\begin{array}{l}.01 \\
.21 \\
.29 \\
.05 \\
.00 \\
-\end{array}$ & $\begin{array}{l}.00 \\
.00 \\
.15 \\
.30 \\
.07 \\
.00\end{array}$ & $\begin{array}{l}.02 \\
.02 \\
.16 \\
.01 \\
.01 \\
.72\end{array}$ & $\begin{array}{l}.05 \\
.00 \\
.00 \\
-0 \\
-\end{array}$ & $\begin{array}{l}.00 \\
.00 \\
.03 \\
.03 \\
.11 \\
.00\end{array}$ & $\begin{array}{l}.44 \\
.13 \\
.04 \\
.00 \\
.07 \\
-0\end{array}$ & $\begin{array}{l}.08 \\
.19 \\
.00 \\
.00 \\
.00 \\
.00\end{array}$ & $\begin{array}{l}.00 \\
.00 \\
.00 \\
.00 \\
.00 \\
-\end{array}$ & $\begin{array}{l}.04 \\
.00 \\
.00 \\
.00 \\
.00 \\
.00\end{array}$ & $\begin{array}{l}.00 \\
.00 \\
.00 \\
.00 \\
.00 \\
.00\end{array}$ & 。 & $\begin{array}{l}.00 \\
.00 \\
.00 \\
.00 \\
.00 \\
-\end{array}$ \\
\hline TOTAL & 2.77 & 6.42 & 10.85 & 5.71 & 3.94 & 2.08 & 4.27 & 4.09 & 1.14 & 1.45 & 2.04 & & 2.94 \\
\hline
\end{tabular}

WTR YR 1978 TOTAL $\quad 47.70$

STATION NUMEER 14211950 VAACOUVER LAKE TRIB NR VANCOUVER

LATITUDE 454136 LONGITUDE 1224203

RAINFALL (IN.), WAIER YEAR OCTOBEK 1977 TO JEPTEMBER 1978

\begin{tabular}{|c|c|c|c|c|c|c|c|c|c|c|c|c|}
\hline DAY & OCI & NOV & OEC & JAN & fES & MAR & APR & MAY & JUN & JUL & AUG & SEP \\
\hline $\begin{array}{l}1 \\
2 \\
3 \\
4 \\
5\end{array}$ & $\begin{array}{l}.00 \\
.00 \\
.00 \\
.00 \\
.00\end{array}$ & $\begin{array}{l}.46 \\
.26 \\
.01 \\
.11 \\
.14\end{array}$ & $\begin{array}{r}.03 \\
1.50 \\
.19 \\
.13 \\
.12\end{array}$ & $\begin{array}{l}.04 \\
.07 \\
.02 \\
.77 \\
.67\end{array}$ & $\begin{array}{l}.48 \\
.58 \\
.28 \\
.00 \\
.00\end{array}$ & $\begin{array}{l}.00 \\
.00 \\
.13 \\
.08 \\
.00\end{array}$ & $\begin{array}{l}.03 \\
.06 \\
.06 \\
.18 \\
.26\end{array}$ & $\begin{array}{l}.01 \\
.00 \\
.00 \\
.20 \\
.00\end{array}$ & $\begin{array}{l}.00 \\
.00 \\
.04 \\
.10 \\
.00\end{array}$ & $\begin{array}{l}.00 \\
.15 \\
.02 \\
.00 \\
.00\end{array}$ & $\begin{array}{l}.00 \\
.00 \\
.00 \\
.00 \\
.00\end{array}$ & $\begin{array}{l}.00 \\
.00 \\
.35 \\
.10 \\
.01\end{array}$ \\
\hline $\begin{array}{r}6 \\
7 \\
8 \\
9 \\
10\end{array}$ & $\begin{array}{l}.25 \\
.30 \\
.00 \\
.00 \\
.00\end{array}$ & $\begin{array}{l}.14 \\
.07 \\
.00 \\
.06 \\
.14\end{array}$ & $\begin{array}{l}.25 \\
.19 \\
.00 \\
.15 \\
.49\end{array}$ & $\begin{array}{l}.00 \\
.33 \\
.42 \\
.43 \\
.02\end{array}$ & $\begin{array}{l}.41 \\
.22 \\
.52 \\
.15 \\
.04\end{array}$ & $\begin{array}{l}.10 \\
.50 \\
.00 \\
.00 \\
.00\end{array}$ & $\begin{array}{l}.01 \\
.00 \\
.00 \\
.00 \\
.00\end{array}$ & $\begin{array}{l}.00 \\
.00 \\
.00 \\
.02 \\
.11\end{array}$ & $\begin{array}{l}.00 \\
.00 \\
.00 \\
.17 \\
.16\end{array}$ & $\begin{array}{l}.00 \\
.00 \\
.00 \\
.00 \\
.00\end{array}$ & $\begin{array}{l}.00 \\
.00 \\
.00 \\
.00 \\
.00\end{array}$ & $\begin{array}{l}.01 \\
.00 \\
.32 \\
.93 \\
.25\end{array}$ \\
\hline $\begin{array}{l}11 \\
12 \\
13 \\
14 \\
15\end{array}$ & $\begin{array}{l}.00 \\
.02 \\
.00 \\
.00 \\
.00\end{array}$ & $\begin{array}{r}.03 \\
.39 \\
.15 \\
.38 \\
.12\end{array}$ & $\begin{array}{r}.47 \\
.97 \\
1.66 \\
.64 \\
.84\end{array}$ & $\begin{array}{l}.11 \\
.02 \\
.38 \\
.17 \\
.15\end{array}$ & $\begin{array}{l}.00 \\
.00 \\
.00 \\
.00 \\
.35\end{array}$ & $\begin{array}{l}.24 \\
.02 \\
.10 \\
.00 \\
.00\end{array}$ & $\begin{array}{l}.00 \\
.00 \\
.31 \\
.19 \\
.35\end{array}$ & $\begin{array}{r}.23 \\
.30 \\
1.28 \\
.60 \\
.03\end{array}$ & $\begin{array}{l}.00 \\
.08 \\
.15 \\
.25 \\
.02\end{array}$ & $\begin{array}{l}.00 \\
.00 \\
.00 \\
.00 \\
.60\end{array}$ & $\begin{array}{l}.00 \\
.80 \\
.05 \\
.00 \\
.60\end{array}$ & $\begin{array}{l}.02 \\
.00 \\
.25 \\
.05 \\
.00\end{array}$ \\
\hline $\begin{array}{l}16 \\
17 \\
18 \\
19 \\
20\end{array}$ & $\begin{array}{l}.00 \\
.00 \\
.00 \\
.00 \\
.00\end{array}$ & $\begin{array}{l}.11 \\
.05 \\
.05 \\
.04 \\
.06\end{array}$ & $\begin{array}{l}.25 \\
.10 \\
.02 \\
.00 \\
.00\end{array}$ & $\begin{array}{l}.29 \\
.24 \\
.43 \\
.02 \\
.01\end{array}$ & $\begin{array}{l}.06 \\
.00 \\
.00 \\
.00 \\
.00\end{array}$ & $\begin{array}{l}.00 \\
.00 \\
.00 \\
.00 \\
.00\end{array}$ & $\begin{array}{l}.25 \\
.43 \\
.28 \\
.28 \\
.04\end{array}$ & $\begin{array}{l}.00 \\
.00 \\
.00 \\
.00 \\
.01\end{array}$ & $\begin{array}{l}.00 \\
.00 \\
.00 \\
.00 \\
.00\end{array}$ & $\begin{array}{l}.40 \\
.00 \\
.00 \\
.00 \\
.00\end{array}$ & $\begin{array}{l}.20 \\
.00 \\
.00 \\
.20 \\
.50\end{array}$ & $\begin{array}{l}.10 \\
.15 \\
.00 \\
.00 \\
.10\end{array}$ \\
\hline $\begin{array}{l}21 \\
22 \\
23 \\
24 \\
25\end{array}$ & $\begin{array}{l}.00 \\
.00 \\
.13 \\
.19 \\
.32\end{array}$ & $\begin{array}{r}.02 \\
.50 \\
.50 \\
.33 \\
1.31\end{array}$ & $\begin{array}{l}.00 \\
.00 \\
.30 \\
.25 \\
.02\end{array}$ & $\begin{array}{l}.25 \\
.00 \\
.00 \\
.00 \\
.18\end{array}$ & $\begin{array}{l}.00 \\
.00 \\
.00 \\
.00 \\
.40\end{array}$ & $\begin{array}{l}.00 \\
.00 \\
.38 \\
.17 \\
.08\end{array}$ & $\begin{array}{l}.21 \\
.17 \\
.00 \\
.01 \\
.14\end{array}$ & $\begin{array}{l}.00 \\
.31 \\
.01 \\
.26 \\
.07\end{array}$ & $\begin{array}{l}.00 \\
.00 \\
.15 \\
.00 \\
.00\end{array}$ & $\begin{array}{l}.00 \\
.00 \\
.00 \\
.00 \\
.00\end{array}$ & $\begin{array}{l}.35 \\
.20 \\
.15 \\
.25 \\
.25\end{array}$ & $\begin{array}{l}.00 \\
.00 \\
.00 \\
.00 \\
.00\end{array}$ \\
\hline $\begin{array}{l}26 \\
27 \\
28 \\
29 \\
30 \\
31\end{array}$ & $\begin{array}{l}.01 \\
.00 \\
.27 \\
.45 \\
.23 \\
.10\end{array}$ & $\begin{array}{l}.00 \\
.17 \\
.23 \\
.03 \\
.00 \\
.0-\end{array}$ & $\begin{array}{l}.00 \\
.00 \\
.15 \\
.35 \\
.20 \\
.02\end{array}$ & $\begin{array}{l}.00 \\
.00 \\
.11 \\
.00 \\
.00 \\
.01\end{array}$ & $\begin{array}{l}.67 \\
.05 \\
.04 \\
-0 \\
-0\end{array}$ & $\begin{array}{l}.00 \\
.00 \\
.01 \\
.00 \\
.05 \\
.01\end{array}$ & $\begin{array}{l}.40 \\
.06 \\
.05 \\
.00 \\
.08 \\
-.0\end{array}$ & $\begin{array}{l}.34 \\
.22 \\
.00 \\
.00 \\
.00 \\
.00\end{array}$ & $\begin{array}{l}.00 \\
.00 \\
.00 \\
.00 \\
.00 \\
\end{array}$ & $\begin{array}{l}.04 \\
.00 \\
.00 \\
.00 \\
.00 \\
.00\end{array}$ & $\begin{array}{l}.02 \\
.00 \\
.00 \\
.00 \\
.03 \\
.00\end{array}$ & $\begin{array}{l}.00 \\
.00 \\
.00 \\
.00 \\
.10 \\
-\end{array}$ \\
\hline TOTAL & 2.27 & 5.86 & 9.29 & 5.14 & 4.27 & 1.87 & 3.85 & 4.05 & 1.12 & 1.21 & 3.60 & 2.74 \\
\hline
\end{tabular}


TABLE 13.-DAILY PRECIPITATION-Continued

STATION NUMBER
LATITUDE
L54136
LONGITUDE 12211950 VANCOUVER LAKE TRIB NR VANCOUVER

RAINFALL (IN.), WATER YEAK OCTOBER 1978 TO SEPTEMBER 1979

\begin{tabular}{|c|c|c|c|c|c|c|c|c|}
\hline DAY & OCT & NOV & DEC & JAN & FES & MAR & APR & MAY \\
\hline $\begin{array}{l}1 \\
2 \\
3 \\
4 \\
5\end{array}$ & $\begin{array}{l}.00 \\
.00 \\
.00 \\
.00 \\
.00\end{array}$ & $\begin{array}{l}.00 \\
.10 \\
.40 \\
.02 \\
.00\end{array}$ & $\begin{array}{l}.13 \\
.03 \\
.11 \\
.62 \\
.00\end{array}$ & $\begin{array}{l}.00 \\
.00 \\
.00 \\
.00 \\
.03\end{array}$ & $\begin{array}{l}.06 \\
.01 \\
.09 \\
.26 \\
.29\end{array}$ & $\begin{array}{l}.01 \\
.01 \\
.62 \\
.55 \\
.20\end{array}$ & $\begin{array}{l}.30 \\
.10 \\
.01 \\
.00 \\
.01\end{array}$ & $\begin{array}{l}.00 \\
.00 \\
.00 \\
.92 \\
.34\end{array}$ \\
\hline $\begin{array}{r}6 \\
7 \\
8 \\
9 \\
10\end{array}$ & $\begin{array}{l}.00 \\
.00 \\
.00 \\
.00 \\
.00\end{array}$ & $\begin{array}{l}.01 \\
.15 \\
.20 \\
.01 \\
.02\end{array}$ & $\begin{array}{l}.01 \\
.00 \\
.03 \\
.16 \\
.73\end{array}$ & $\begin{array}{r}.01 \\
.04 \\
.00 \\
.10 \\
1.20\end{array}$ & $\begin{array}{r}1.02 \\
.23 \\
.10 \\
.05 \\
.59\end{array}$ & $\begin{array}{l}.12 \\
.01 \\
.00 \\
.00 \\
.00\end{array}$ & $\begin{array}{l}.00 \\
.00 \\
.19 \\
.21 \\
.34\end{array}$ & $\begin{array}{l}.24 \\
.24 \\
.00 \\
-0- \\
---\end{array}$ \\
\hline $\begin{array}{l}11 \\
12 \\
13 \\
14 \\
15\end{array}$ & $\begin{array}{l}.00 \\
.00 \\
.00 \\
.00 \\
.00\end{array}$ & $\begin{array}{l}.00 \\
.01 \\
.04 \\
.03 \\
.05\end{array}$ & $\begin{array}{l}.08 \\
.01 \\
.04 \\
.11 \\
.01\end{array}$ & $\begin{array}{l}.20 \\
.01 \\
.00 \\
.25 \\
.00\end{array}$ & $\begin{array}{l}.60 \\
.30 \\
.12 \\
.01 \\
.18\end{array}$ & $\begin{array}{l}.00 \\
.00 \\
.00 \\
.05 \\
.33\end{array}$ & $\begin{array}{l}.06 \\
.20 \\
.02 \\
.06 \\
.14\end{array}$ & $\begin{array}{l}--- \\
=- \\
-\cdots\end{array}$ \\
\hline $\begin{array}{l}16 \\
17 \\
18 \\
19 \\
20\end{array}$ & $\begin{array}{l}.00 \\
.00 \\
.00 \\
.00 \\
.08\end{array}$ & $\begin{array}{r}.20 \\
.04 \\
.40 \\
.30 \\
.15\end{array}$ & $\begin{array}{l}.01 \\
.05 \\
.00 \\
.00 \\
.22\end{array}$ & $\begin{array}{l}.01 \\
.04 \\
.01 \\
.25 \\
.00\end{array}$ & $\begin{array}{l}.34 \\
.20 \\
.06 \\
.05 \\
.05\end{array}$ & $\begin{array}{l}.25 \\
.02 \\
.00 \\
.01 \\
.00\end{array}$ & $\begin{array}{l}.18 \\
.18 \\
.33 \\
.01 \\
.01\end{array}$ & $\begin{array}{l}=- \\
=- \\
=-\end{array}$ \\
\hline $\begin{array}{l}21 \\
22 \\
23 \\
24 \\
25\end{array}$ & $\begin{array}{l}.00 \\
.00 \\
.00 \\
.02 \\
.00\end{array}$ & $\begin{array}{l}.06 \\
.02 \\
.03 \\
.00 \\
.01\end{array}$ & $\begin{array}{l}.05 \\
.02 \\
.0 .3 \\
.08 \\
.00\end{array}$ & $\begin{array}{l}.15 \\
.01 \\
.10 \\
.07 \\
.00\end{array}$ & $\begin{array}{l}.01 \\
.71 \\
.22 \\
.53 \\
.33\end{array}$ & $\begin{array}{l}.00 \\
.00 \\
.00 \\
.00 \\
.00\end{array}$ & $\begin{array}{l}.00 \\
.07 \\
.57 \\
.01 \\
.00\end{array}$ & $\overline{-}=\overline{-}$ \\
\hline $\begin{array}{l}26 \\
27 \\
28 \\
29 \\
30 \\
31\end{array}$ & $\begin{array}{l}.00 \\
.00 \\
.30 \\
.30 \\
.01 \\
.00\end{array}$ & $\begin{array}{l}.00 \\
.35 \\
.38 \\
.28 \\
.69 \\
.-\end{array}$ & $\begin{array}{l}.00 \\
.01 \\
.19 \\
.11 \\
.00 \\
.00\end{array}$ & $\begin{array}{r}.05 \\
.27 \\
.01 \\
.06 \\
.08 \\
.10\end{array}$ & $\begin{array}{l}.01 \\
.31 \\
.65 \\
- \\
-0 \\
-\end{array}$ & $\begin{array}{l}.13 \\
.20 \\
.06 \\
.02 \\
.04 \\
.06\end{array}$ & $\begin{array}{l}.00 \\
.27 \\
.03 \\
.00 \\
.00 \\
.0\end{array}$ & $\begin{array}{l}=- \\
\square- \\
\square- \\
-\cdots\end{array}$ \\
\hline TOTAL & 0.71 & 4.45 & 2.84 & 3.05 & 7.40 & 2.69 & 3.30 & 1.74 \\
\hline
\end{tabular}

WTR YR 1979 TOTAL 26.18 NOTE: NUMBER OF MISSING DAYS OF RECORD EXCEEUED 203 OF YEAR

STATION NUMBER 14213030 RAIN GAGE ON COLUMBIA $R$ HIGH SCHOOL

RAINFALL (IN.), WATER YEAR OCTGBER 1977 TO SEPTEMBER 1978

\begin{tabular}{|c|c|c|c|c|c|c|c|c|c|c|c|c|}
\hline DAY & UCT & NOV & DEC & JAN & $F E B$ & MAR & APR & MAY & JUN & JUL & AUG & SEP \\
\hline $\begin{array}{l}1 \\
2 \\
3 \\
4 \\
.5\end{array}$ & $\begin{array}{l}.00 \\
.00 \\
.00 \\
.00 \\
.00\end{array}$ & $\begin{array}{l}.46 \\
.18 \\
.01 \\
.10 \\
.14\end{array}$ & $\begin{array}{r}.03 \\
1.39 \\
.23 \\
.14 \\
.13\end{array}$ & $\begin{array}{l}.00 \\
.01 \\
.15 \\
.71 \\
.71\end{array}$ & $\begin{array}{l}.62 \\
.31 \\
.02 \\
.00 \\
.44\end{array}$ & $\begin{array}{r}.01 \\
.00 \\
.10 \\
.06 \\
.00\end{array}$ & $\begin{array}{l}.06 \\
.07 \\
.07 \\
.17 \\
.32\end{array}$ & $\begin{array}{l}.00 \\
.00 \\
.00 \\
.20 \\
.00\end{array}$ & $\begin{array}{l}.00 \\
.01 \\
.01 \\
.00 \\
.00\end{array}$ & $\begin{array}{l}.00 \\
.12 \\
.03 \\
.00 \\
.00\end{array}$ & $\begin{array}{l}.00 \\
.00 \\
.00 \\
.00 \\
.00\end{array}$ & $\begin{array}{l}.00 \\
.00 \\
.35 \\
.10 \\
.07\end{array}$ \\
\hline $\begin{array}{r}6 \\
7 \\
8 \\
9 \\
10\end{array}$ & $\begin{array}{l}.26 \\
.32 \\
.01 \\
.01 \\
.00\end{array}$ & $\begin{array}{l}.16 \\
.06 \\
.00 \\
.06 \\
.13\end{array}$ & $\begin{array}{l}.20 \\
.19 \\
.00 \\
.14 \\
.54\end{array}$ & $\begin{array}{r}.01 \\
.30 \\
.40 \\
.42 \\
.04\end{array}$ & $\begin{array}{l}.25 \\
.63 \\
.18 \\
.08 \\
.01\end{array}$ & $\begin{array}{l}.08 \\
.48 \\
.01 \\
.00 \\
.00\end{array}$ & $\begin{array}{l}.02 \\
.00 \\
.00 \\
.00 \\
.00\end{array}$ & $\begin{array}{l}.00 \\
.00 \\
.00 \\
.01 \\
.13\end{array}$ & $\begin{array}{l}.00 \\
.00 \\
.00 \\
.24 \\
.20\end{array}$ & $\begin{array}{l}.01 \\
.00 \\
.00 \\
.00 \\
.00\end{array}$ & $\begin{array}{l}.00 \\
.00 \\
.00 \\
.00 \\
.00\end{array}$ & $\begin{array}{l}.00 \\
.01 \\
.27 \\
.85 \\
.19\end{array}$ \\
\hline $\begin{array}{l}11 \\
12 \\
13 \\
14 \\
15\end{array}$ & $\begin{array}{l}.00 \\
.03 \\
.01 \\
.00 \\
.00\end{array}$ & $\begin{array}{l}.03 \\
.44 \\
.18 \\
.35 \\
.11\end{array}$ & $\begin{array}{r}.49 \\
.97 \\
1.66 \\
.64 \\
.84\end{array}$ & $\begin{array}{l}.12 \\
.04 \\
.35 \\
.16 \\
.17\end{array}$ & $\begin{array}{r}.00 \\
.01 \\
.01 \\
.38 \\
.11\end{array}$ & $\begin{array}{l}.19 \\
.02 \\
.11 \\
.00 \\
.00\end{array}$ & $\begin{array}{l}.00 \\
.00 \\
.29 \\
.25 \\
.39\end{array}$ & $\begin{array}{r}.21 \\
.30 \\
1.25 \\
.62 \\
.06\end{array}$ & $\begin{array}{l}.00 \\
.18 \\
.26 \\
.19 \\
.03\end{array}$ & $\begin{array}{l}.00 \\
.00 \\
.00 \\
.00 \\
.54\end{array}$ & $\begin{array}{l}.00 \\
.78 \\
.05 \\
.00 \\
.63\end{array}$ & $\begin{array}{l}.02 \\
.00 \\
.24 \\
.03 \\
.00\end{array}$ \\
\hline $\begin{array}{l}16 \\
17 \\
18 \\
19 \\
20\end{array}$ & $\begin{array}{l}.00 \\
000 \\
.00 \\
.00 \\
000\end{array}$ & $\begin{array}{l}.10 \\
.07 \\
.09 \\
.04 \\
.04\end{array}$ & $\begin{array}{l}.26 \\
.12 \\
.02 \\
.00 \\
.00\end{array}$ & $\begin{array}{l}.31 \\
.27 \\
.43 \\
.04 \\
.05\end{array}$ & $\begin{array}{l}.02 \\
.01 \\
.01 \\
.01 \\
.00\end{array}$ & $\begin{array}{l}.00 \\
.00 \\
.00 \\
.00 \\
.00\end{array}$ & $\begin{array}{l}.36 \\
.42 \\
.42 \\
.30 \\
.05\end{array}$ & $\begin{array}{l}.00 \\
.00 \\
.00 \\
.00 \\
.00\end{array}$ & $\begin{array}{l}.01 \\
.01 \\
.00 \\
.00 \\
.00\end{array}$ & $\begin{array}{l}.35 \\
.00 \\
.00 \\
.00 \\
.00\end{array}$ & $\begin{array}{l}.21 \\
.01 \\
.00 \\
.19 \\
.53\end{array}$ & $\begin{array}{l}.08 \\
.16 \\
.01 \\
.00 \\
.09\end{array}$ \\
\hline $\begin{array}{l}21 \\
22 \\
23 \\
24 \\
25\end{array}$ & $\begin{array}{l}.00 \\
.00 \\
.11 \\
.21 \\
.41\end{array}$ & $\begin{array}{r}.00 \\
.50 \\
.00 \\
.44 \\
1.32\end{array}$ & $\begin{array}{l}.00 \\
.01 \\
.30 \\
.26 \\
.02\end{array}$ & $\begin{array}{l}.36 \\
.03 \\
.00 \\
.00 \\
.22\end{array}$ & $\begin{array}{l}.00 \\
.01 \\
.00 \\
.39 \\
.73\end{array}$ & $\begin{array}{l}.00 \\
.00 \\
.38 \\
.16 \\
.09\end{array}$ & $\begin{array}{l}.23 \\
.21 \\
.01 \\
.00 \\
.12\end{array}$ & $\begin{array}{l}.00 \\
.35 \\
.01 \\
.26 \\
.06\end{array}$ & $\begin{array}{l}.00 \\
.01 \\
.16 \\
.00 \\
.00\end{array}$ & $\begin{array}{l}.00 \\
.00 \\
.00 \\
.00 \\
.00\end{array}$ & $\begin{array}{l}.34 \\
.15 \\
.15 \\
.25 \\
.24\end{array}$ & $\begin{array}{l}.01 \\
.00 \\
.00 \\
.01 \\
.00\end{array}$ \\
\hline $\begin{array}{l}26 \\
27 \\
28 \\
29 \\
30 \\
31\end{array}$ & $\begin{array}{l}.01 \\
.00 \\
.24 \\
.47 \\
.23 \\
.11\end{array}$ & $\begin{array}{l}.00 \\
.20 \\
.20 \\
.03 \\
.01 \\
-.-\end{array}$ & $\begin{array}{l}.01 \\
.00 \\
.17 \\
.34 \\
.20 \\
.02\end{array}$ & $\begin{array}{l}.01 \\
.00 \\
.25 \\
.08 \\
.00 \\
.49\end{array}$ & $\begin{array}{r}.09 \\
.00 \\
.02 \\
-2 \\
-0\end{array}$ & $\begin{array}{l}.01 \\
.00 \\
.00 \\
.00 \\
.04 \\
.00\end{array}$ & $\begin{array}{l}.43 \\
.06 \\
.08 \\
.00 \\
.09 \\
.-\end{array}$ & $\begin{array}{l}.38 \\
.24 \\
.00 \\
.00 \\
.00 \\
.00\end{array}$ & $\begin{array}{l}.00 \\
.00 \\
.00 \\
.00 \\
.00 \\
\end{array}$ & $\begin{array}{l}.01 \\
.00 \\
.00 \\
.00 \\
.00 \\
.00\end{array}$ & $\begin{array}{l}.02 \\
.00 \\
.00 \\
.00 \\
.02 \\
.01\end{array}$ & $\begin{array}{l}.00 \\
.00 \\
.00 \\
.00 \\
.10 \\
-\end{array}$ \\
\hline TOTAL & 2.43 & 6.05 & 9.32 & 6.13 & 4.34 & 1.74 & 4.42 & 4.08 & 1.31 & 1.06 & $3.5 B$ & 2.59 \\
\hline
\end{tabular}

WTR YR 1978 TOTAL $\quad 47.05$ 
TABLE 13,-DAILY PRECIPITATION-Continued

STATION NUMBER
LATITUDE
L54138

RAINFALL (IN,), WATEK YEAR OCTOBER 1978 TO SEPTEMBER 1979

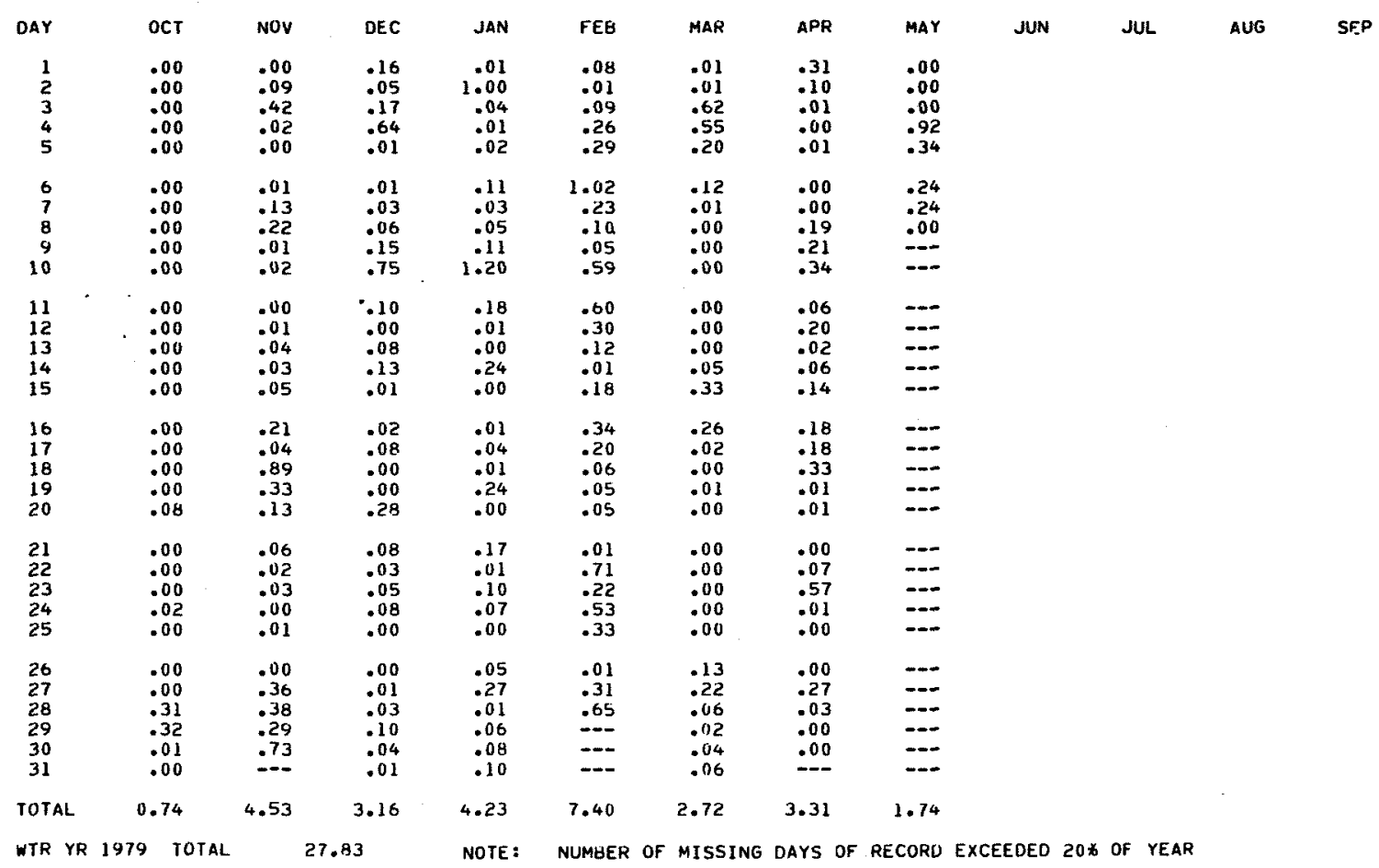


Station number and name: 14142580 - Kelly Creek

Location: Lat $45^{\circ} 30^{\prime} 44^{\prime \prime}$, long $122^{\circ} 23^{\prime} 56^{\prime \prime}$.

Control: At low stages, it is a rock and gravel riffle; at high stages, it is a large 13- by $8 \frac{1}{2}$-ft arch culvert (type II flow). Datum: Zero datum is $0.08 \mathrm{ft}$ below upstream invert.

Rain gage (1) gtation no. 14142570

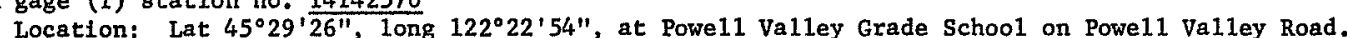

\begin{tabular}{|c|c|c|c|c|c|c|c|c|c|c|c|c|c|c|c|c|c|c|c|c|c|c|c|c|}
\hline \multirow{2}{*}{\multicolumn{8}{|c|}{ Storm }} & \multirow{5}{*}{ 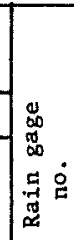 } & \multirow{3}{*}{\multicolumn{7}{|c|}{ Precipitation (inches) }} & \multirow{5}{*}{ 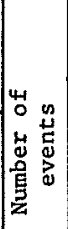 } & \multicolumn{7}{|c|}{ Discharge peak. } & \multirow[b]{5}{*}{ Remarks } \\
\hline & & & & & & & & & & & & & & & & & & & Time & & & Magni & tude & \\
\hline \multirow{3}{*}{$\underset{D}{J}$} & \multicolumn{3}{|c|}{ Begin } & \multicolumn{4}{|c|}{ End } & & & & & & & & & & \multirow{3}{*}{ 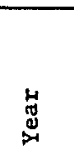 } & \multirow{3}{*}{$\begin{array}{l}\text { 䓌 } \\
\text { 号 }\end{array}$} & \multirow[b]{3}{*}{ 害 } & \multirow{3}{*}{ 岁 } & \multirow{3}{*}{ 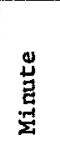 } & \multirow{3}{*}{ 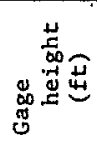 } & \multirow{3}{*}{ 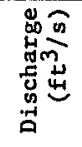 } & \\
\hline & 专 & & $H$ & & تئي & & 4 & & & inute & sing & 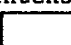 & ours & & \multirow[b]{2}{*}{ Tota 1} & & & & & & & & & \\
\hline & 产 & 合 & 票 & $\stackrel{g}{2}$ & $\frac{0}{2}$ & 咅 & 옥 & & 5 & 15 & 30 & 1 & 6 & 24 & & & & & & & & & & \\
\hline 1978 & 05 & 13 & 0 & 1978 & 05 & 14 & 24 & 1 & 0.02 & 0.05 & 0.09 & 0.16 & 0.5 & 1.41 & 2.31 & 1 & 1978 & 05 & 14 & 20 & 20 & 2.66 & 83.00 & \\
\hline
\end{tabular}

Station number and name: 14144690 - Vancouver sewer outfal1

Location: Lat $45^{\circ} 37^{\prime} 21^{\prime \prime}$, long $122^{\circ} 40^{\prime} 14^{\prime \prime}$.

Contro1: A $90^{\circ}$ sharp-crested weir set on the end of a 5 -foot-dtameter concrete sewer pipe set 0.15 in. above pipe invert.

Datum: Zero datum is at bottom of weir notch.

Rain gage (1) station no. 14144680

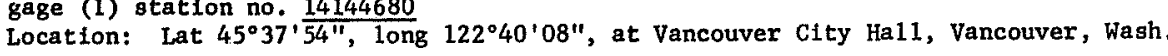

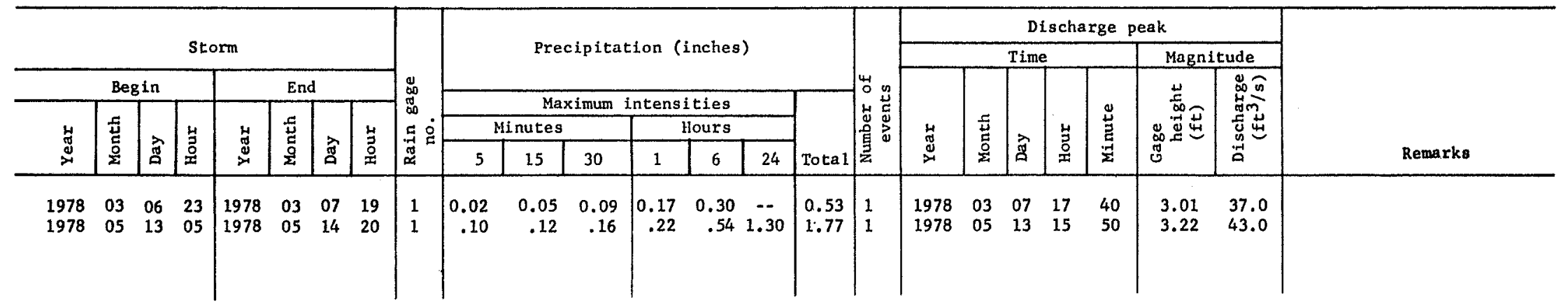


Station number and name: 14206320 - Beaverton Creek near Cedar Hills Boulevard at Beaverton, Oreg.

Location: Lat $45^{\circ} 29^{\prime} 02^{\prime \prime}$, long $122^{\circ} 48^{\prime} 11^{\prime \prime}$.

Control: At low stages, a grass and silt riffle; at high stages, channel control subject to backwater.

Datum: Zero datum.
Rain gage (1) station no. 14206310

Location: Lat $45^{\circ} 29^{\prime} 3^{\prime \prime}$, long $122^{\circ} 45^{\prime} 21^{\prime \prime}$, at Raleigh Park Grade School above Raleigh Park in West Slope.

Rain gage (2) station no. 14206315

Location: Lat $45^{\circ} 29^{\prime} 02^{\prime \prime}$, long $122^{\circ} 48^{\prime} 11^{\prime \prime}$, on Beaverton City Hall on Hall Boulevard in Beaverton.

\begin{tabular}{|c|c|c|c|c|c|c|c|c|c|c|c|c|c|c|c|c|c|c|c|c|c|c|c|c|}
\hline \multirow{2}{*}{\multicolumn{8}{|c|}{ Storm }} & \multirow{5}{*}{ 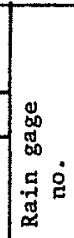 } & \multirow{3}{*}{\multicolumn{7}{|c|}{ Precipitation (inches) }} & \multirow{5}{*}{ 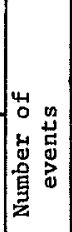 } & \multicolumn{7}{|c|}{ Discharge peak } & \multirow[b]{5}{*}{ Remarks } \\
\hline & & & & & & & & & & & & & & & & & \multirow{4}{*}{ yु } & \multicolumn{3}{|c|}{ Time } & & \multicolumn{2}{|c|}{ Magnitude } & \\
\hline \multirow{3}{*}{ 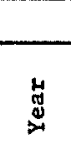 } & \multicolumn{3}{|c|}{ Begin } & \multicolumn{4}{|c|}{ End } & & & & & & & & & & & \multirow{3}{*}{ 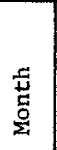 } & \multirow[b]{3}{*}{ 空 } & \multirow{3}{*}{ 岁 } & \multirow{3}{*}{ 岂 } & \multirow{3}{*}{ 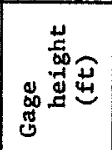 } & \multirow{3}{*}{ 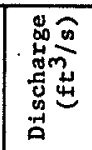 } & \\
\hline & 도 & & & & ᄃ & & & & \multicolumn{6}{|c|}{ Maximum intensities } & \multirow[b]{2}{*}{ Tota 1} & & & & & & & & & \\
\hline & : & 高 & 胥 & 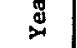 & 尧 & 弇 & 亭 & & 5 & 15 & 30 & 1 & 6 & 24 & & & & & & & & & & \\
\hline 1978 & 05 & 13 & 04 & 1978 & 05 & 15 & 19 & $\begin{array}{l}1 \\
2\end{array}$ & $\begin{array}{r}0.17 \\
.12\end{array}$ & $\begin{array}{r}0.35 \\
.19\end{array}$ & $\begin{array}{r}0.38 \\
.20\end{array}$ & $\begin{array}{r}0.42 \\
.25\end{array}$ & $\begin{array}{r}0.57 \\
.59\end{array}$ & $\begin{array}{l}1.48 \\
1.47\end{array}$ & $\begin{array}{l}2.55 \\
2.24\end{array}$ & 3 & 1978 & 05 & 13 & 17 & 30 & 4.25 & 126.0 & \\
\hline 1978 & 09 & 08 & 23 & 1978 & 09 & 11 & 16 & $\begin{array}{l}1 \\
2\end{array}$ & $\begin{array}{l}.13 \\
.10\end{array}$ & $\begin{array}{l}.24 \\
.19\end{array}$ & $\begin{array}{l}.29 \\
.25\end{array}$ & $\begin{array}{l}.34 \\
.29\end{array}$ & $\begin{array}{l}.57 \\
.59\end{array}$ & $\begin{array}{l}.83 \\
.85\end{array}$ & $\begin{array}{l}1.45 \\
1.55\end{array}$ & $\begin{array}{l}3 \\
3\end{array}$ & 1978 & 09 & 09 & 08 & 25 & 3.79 & 104.0 & \\
\hline
\end{tabular}

Station number and name: 14206330 - Beaverton Creek tributary at SW. Murray Boulevard at Beaverton, Oreg.

Location: Lat $45^{\circ} 20^{\prime} 08^{\prime \prime}$, long $122^{\circ} 51^{\prime} 41^{\prime \prime}$.

Control: A 2-foot-diameter concrete culvert (type I to $\mathrm{V}$ control).

Datum: Zero datum is $0.07 \mathrm{ft}$ above upstream culvert invert.

Rain gage (1) at stream-gage site.

\begin{tabular}{|c|c|c|c|c|c|c|c|c|c|c|c|c|c|c|c|c|c|c|c|c|c|c|c|c|}
\hline \multirow{2}{*}{\multicolumn{8}{|c|}{ Storm }} & \multirow{6}{*}{ 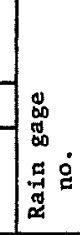 } & \multirow{3}{*}{\multicolumn{7}{|c|}{ Precipitation (inches) }} & \multirow{6}{*}{ 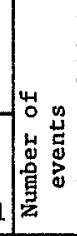 } & \multicolumn{7}{|c|}{ Discharge peak } & \multirow[b]{6}{*}{ Remarke } \\
\hline & & & & & & & & & & & & & & & & & \multirow{5}{*}{ 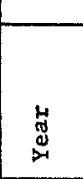 } & \multicolumn{3}{|c|}{ Time } & & \multicolumn{2}{|c|}{ Magnitude } & \\
\hline \multirow{4}{*}{ है } & \multicolumn{3}{|c|}{ Begin } & \multirow{2}{*}{\multicolumn{4}{|c|}{ End }} & & & & & & & & & & & & & & \multirow{4}{*}{ 胥 } & \multirow{4}{*}{ 崖 } & \multirow{4}{*}{ 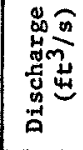 } & \\
\hline & \multirow{3}{*}{$\begin{array}{l}\text { 펼 } \\
\text { 일 }\end{array}$} & \multirow{3}{*}{ 究 } & & & & & & & \multicolumn{6}{|c|}{ Maximum intensities } & \multirow{3}{*}{ Tota 1} & & & \multirow{3}{*}{ 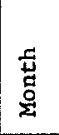 } & & \multirow{3}{*}{ 岂 } & & & & \\
\hline & & & \multirow{2}{*}{ 崫 } & \multirow{2}{*}{ 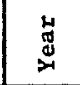 } & \multirow{2}{*}{ 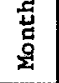 } & \multirow{2}{*}{ 总 } & \multirow{2}{*}{ 岂 } & & \multicolumn{3}{|c|}{ Minutes } & \multicolumn{3}{|c|}{ Hours } & & & & & \multirow{2}{*}{ 梁 } & & & & & \\
\hline & & & & & & & & & 5 & 15 & 30 & 1 & 6 & 24 & & & & & & & & & & \\
\hline 1978 & 04 & 27 & 17 & 1978 & 04 & 27 & 18 & 1 & 0.07 & 0.10 & 0.10 & 0.10 & -- & -- & 0.10 & 1 & 1978 & 04 & 27 & 17 & 35 & & 5.1 & \\
\hline 1978 & 05 & 13 & 04 & 1978 & 05 & 14 & 20 & 1 & .08 & .15 & .17 & .20 & 0.55 & 1.37 & 1.95 & 2 & 1978 & 05 & 13 & 15 & 25 & 1.77 & 12.0 & \\
\hline 1978 & 05 & 22 & 11 & 1978 & 05 & 22 & 20 & 1 & .13 & .23 & .27 & .28 & .32 & -- & .34 & 1 & 1978 & 05 & 22 & 17 & 20 & 1.83 & 13.0 & \\
\hline 1978 & 07 & 15 & 17 & 1978 & 07 & 15 & 21 & 1 & .09 & .21 & .33 & .45 & .77 & -- & .77 & 1 & 1978 & 07 & 15 & 18 & 10 & 1.89 & 14.0 & \\
\hline
\end{tabular}




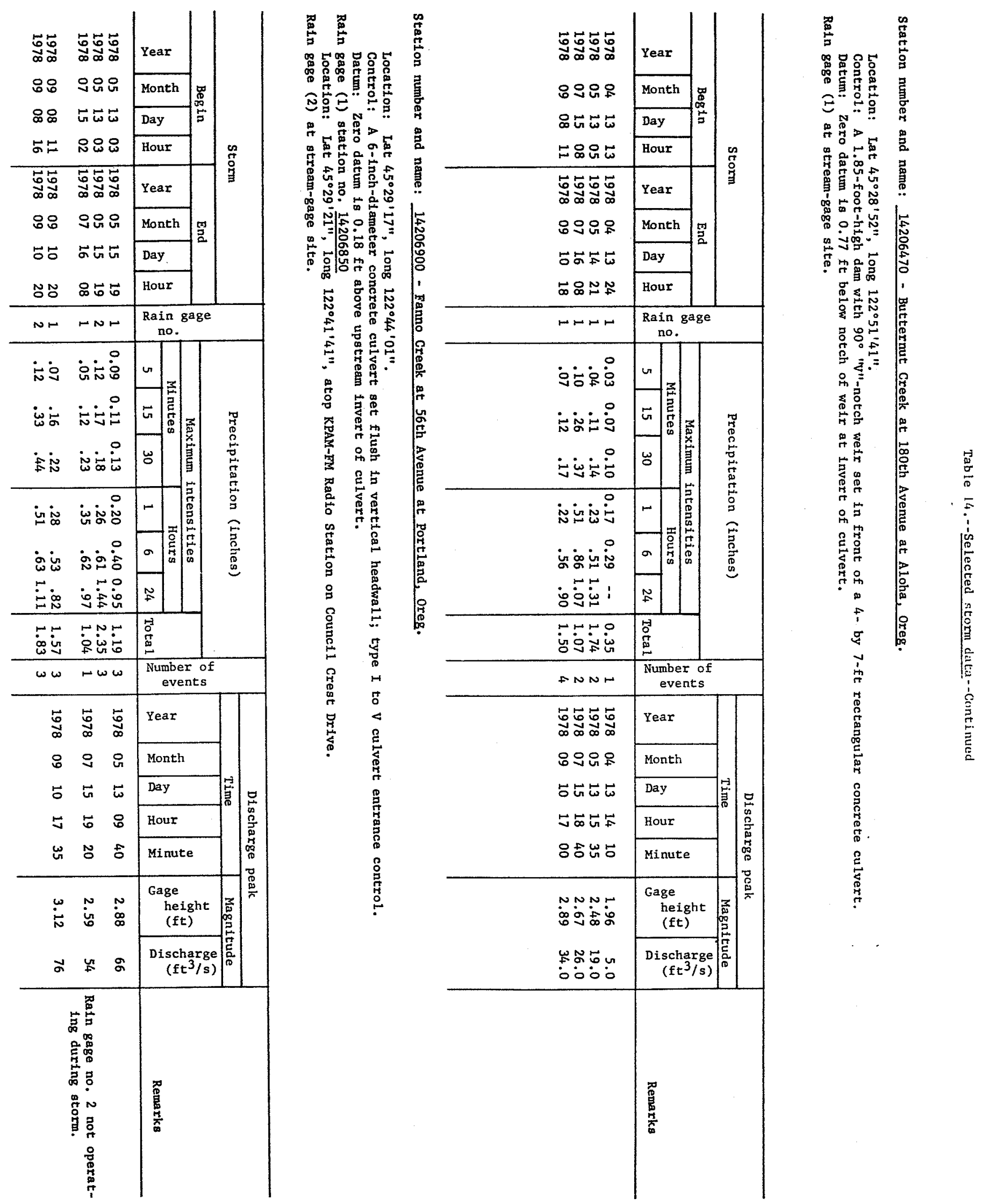




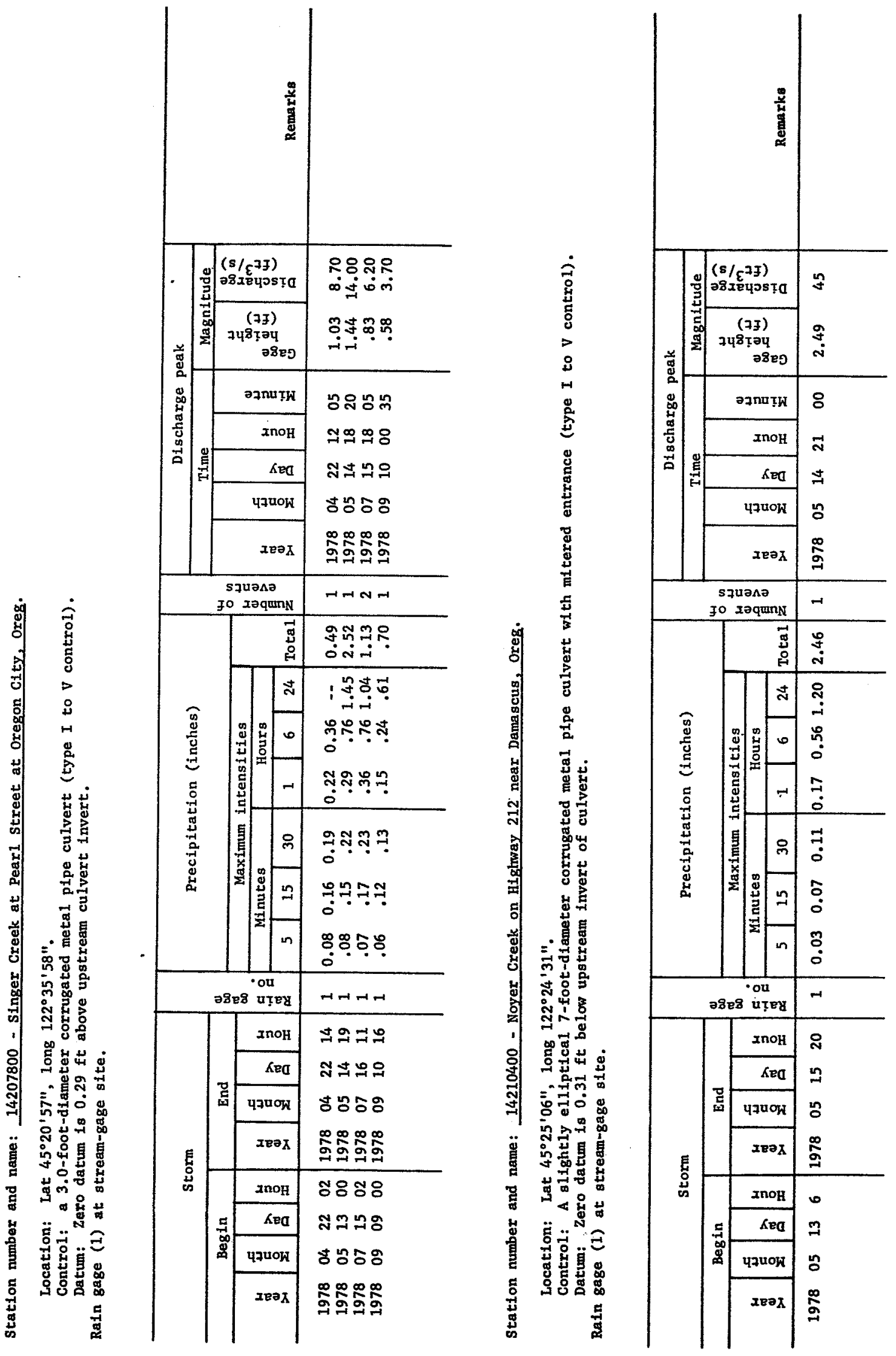


Station number and name: 14211110 - Willamette River tributary at Old River Road at Robinwood, Oreg.

Location: Lat $45^{\circ} 24^{\prime} 01^{\prime \prime}$, long $122^{\circ} 38^{\prime} 37^{\prime \prime}$.

Control: A 5-foot-diameter corrugated metal pipe culvert (type I to $\mathrm{V}$ control).

Datum: Zero datum is $0.10 \mathrm{ft}$ above upstream invert of culvert.

Rain gage (1) station no. $\frac{14211105}{24^{\prime \prime}, 10 n}$

Location: Lat $45^{\circ} 23^{\prime} 24^{\prime \prime}$, long $122^{\circ} 38^{\prime} 53^{\prime \prime}$, on View Drive, located near large water tanks at Robinwood, Oreg.

\begin{tabular}{|c|c|c|c|c|c|c|c|c|c|c|c|c|c|c|c|c|c|c|c|c|c|c|c|c|}
\hline \multirow{2}{*}{\multicolumn{8}{|c|}{ Storm }} & \multirow{5}{*}{ 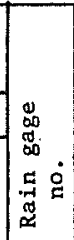 } & \multirow{3}{*}{\multicolumn{7}{|c|}{ Precipitation (inches) }} & \multirow{5}{*}{ 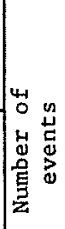 } & \multicolumn{7}{|c|}{ Discharge peak } & \multirow[b]{5}{*}{ Remarks } \\
\hline & & & & & & & & & & & & & & & & & & & Time & & & Magn & tude & \\
\hline \multirow{3}{*}{$\underset{\text { d્ર }}{\stackrel{\text { J }}{2}}$} & \multicolumn{3}{|c|}{ Begin } & \multicolumn{4}{|c|}{ End } & & & & & & & & & & \multirow{3}{*}{ 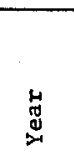 } & \multirow{3}{*}{ 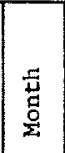 } & \multirow[b]{3}{*}{ 要 } & \multirow{3}{*}{ 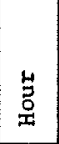 } & \multirow{3}{*}{ 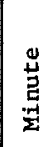 } & \multirow{3}{*}{ 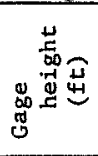 } & \multirow{3}{*}{ 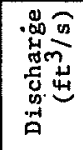 } & \\
\hline & & & & & & & & & \multicolumn{6}{|c|}{ Maximum intensities } & \multirow{2}{*}{\begin{tabular}{|c|} 
Tota 1 \\
\end{tabular}} & & & & & & & & & \\
\hline & 泀 & 窟 & $\stackrel{\vec{g}}{g}$ & 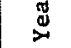 & 胥 & त् & 胥 & & 5 & 15 & 30 & 1 & 6 & 24 & & & & & & & & & & \\
\hline $\begin{array}{l}1978 \\
1978\end{array}$ & $\begin{array}{l}04 \\
05\end{array}$ & $\begin{array}{l}22 \\
13\end{array}$ & $\begin{array}{l}0 \\
1\end{array}$ & $\begin{array}{l}1978 \\
1978\end{array}$ & $\begin{array}{l}04 \\
05\end{array}$ & $\begin{array}{l}22 \\
15\end{array}$ & $\begin{array}{r}24 \\
4\end{array}$ & $\begin{array}{l}1 \\
1\end{array}$ & $\begin{array}{r}0.09 \\
.06\end{array}$ & $\begin{array}{r}0.16 \\
.12\end{array}$ & $\begin{array}{r}0.18 \\
.20\end{array}$ & $\begin{array}{r}0.22 \\
.31\end{array}$ & $\begin{array}{r}0.39 \\
.75\end{array}$ & $\begin{array}{l}0.52 \\
1.57\end{array}$ & $\begin{array}{l}0.53 \\
2.74\end{array}$ & $\begin{array}{l}1 \\
1\end{array}$ & $\begin{array}{l}1978 \\
1978\end{array}$ & $\begin{array}{l}04 \\
05\end{array}$ & $\begin{array}{l}22 \\
14\end{array}$ & $\begin{array}{l}12 \\
19\end{array}$ & $\begin{array}{l}35 \\
45\end{array}$ & $\begin{array}{l}1.13 \\
1.55\end{array}$ & $\begin{array}{l}10 \\
18\end{array}$ & \\
\hline
\end{tabular}

Station number and name: 14211120 - Willamette River tributary at SE. River Road at Oak Grove, Oreg.

Location: Lat $45^{\circ} 24^{\prime} 34^{\prime \prime}$, long $122^{\circ} 38^{\prime} 39^{\prime \prime}$.

Control: A 4.6-foot-diameter corrugated metal pipe culvert (type I to V contro1).

Datum: Zero datum is $0.16 \mathrm{ft}$ above upstream Invert of culvert.

Rain gage (1) station no. 1411115

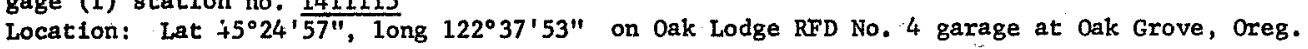

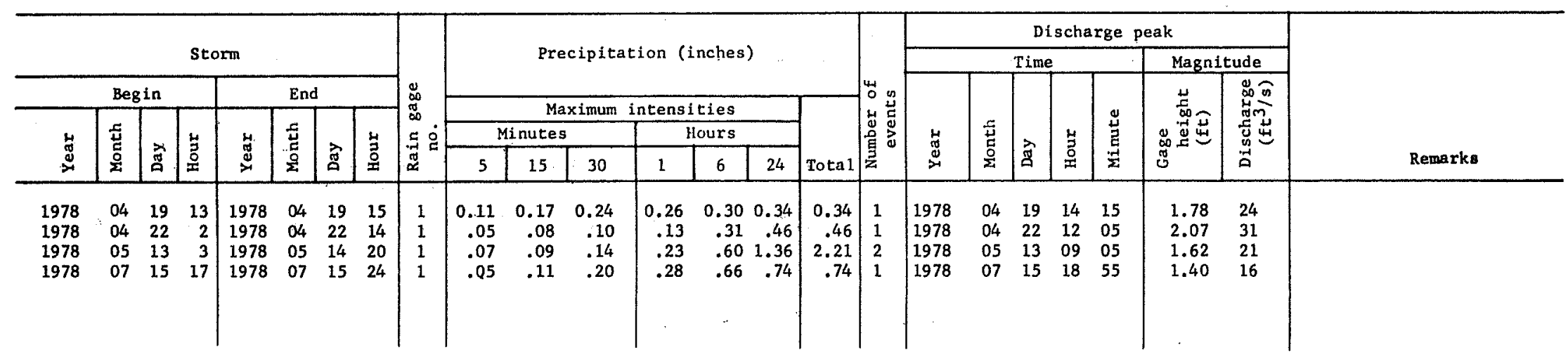


Station number and name: 14211130 - Kellogg Creek at Rusk Road at Milwaukie, Oreg.

Location: Lat $45^{\circ} 25^{\prime} 23^{\prime \prime}$, long $122^{\circ} 36^{\prime} 09^{\prime \prime}$.

Control: Two paralle1 2.5-foot-diameter concrete culverts (type I to $\mathrm{V}$ control).

Datum: Zero datum.1s $0.20 \mathrm{ft}$ above upstream invert of right bank culvert.

Rain gage (1) station no. 14211125

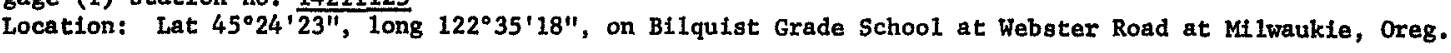

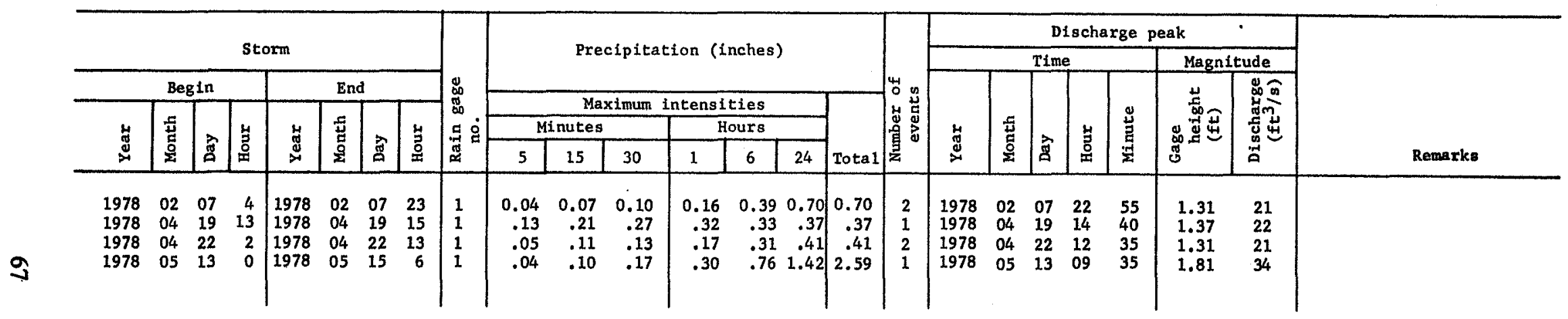

Station number and name: 14211301 - Tryon Creek tributary at Dolph Court at Portland, Oreg.

Location: Lat $45^{\circ} 27^{\prime} 43^{\prime \prime}$, long $122^{\circ} 42^{\prime} 18^{\prime \prime}$.

Control: A 3.0-foot-diameter corrugated metal pipe culvert (type I to V contro1).

Datum: Zero datum is $0.03 \mathrm{ft}$ above upstream invert of culvert.

Rain gage (1) at atream-gage site.

\begin{tabular}{|c|c|c|c|c|c|c|c|c|c|c|c|c|c|c|c|c|c|c|c|c|c|c|c|c|}
\hline \multirow{2}{*}{\multicolumn{8}{|c|}{ Storm }} & \multirow{5}{*}{ 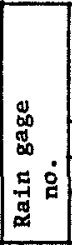 } & \multirow{3}{*}{\multicolumn{6}{|c|}{ Precipitation (inches) }} & & \multirow{5}{*}{ 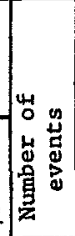 } & \multicolumn{7}{|c|}{ Discharge peak } & \multirow[b]{5}{*}{ Remarke } \\
\hline & & & & & & & & & & & & & & & & & \multicolumn{5}{|c|}{ Time } & \multicolumn{2}{|c|}{ Magnitude } & \\
\hline \multirow{3}{*}{ 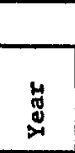 } & \multicolumn{3}{|c|}{ Begin } & \multicolumn{4}{|c|}{ End } & & & & & & & & & & \multirow{3}{*}{$\underset{\nu}{\stackrel{y}{d y ~}}$} & \multirow{3}{*}{ 营 } & \multirow[b]{3}{*}{. } & \multirow{3}{*}{ 岂 } & \multirow{3}{*}{ 莡 } & \multirow{3}{*}{ 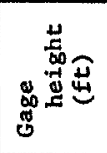 } & \multirow{3}{*}{ 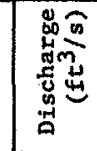 } & \\
\hline & \multirow{2}{*}{$\begin{array}{l}\text { 돌 } \\
\text { 온 }\end{array}$} & \multirow[b]{2}{*}{ 曋 } & \multirow{2}{*}{ 疋 } & \multirow{2}{*}{ 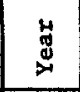 } & \multirow{2}{*}{$\begin{array}{l}\text { 펼 } \\
\text { 열 }\end{array}$} & \multirow{2}{*}{ 票 } & \multirow{2}{*}{ 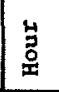 } & & \multicolumn{3}{|c|}{ Minutes } & \multicolumn{3}{|c|}{\begin{tabular}{|l|} 
Hours \\
\end{tabular}} & \multirow{2}{*}{ Tota 1} & & & & & & & & & \\
\hline & & & & & & & & & 5 & 15 & 30 & 1 & 6 & 24 & & & & & & & & & & \\
\hline $\begin{array}{l}1978 \\
1978 \\
1978\end{array}$ & $\begin{array}{l}04 \\
05 \\
07\end{array}$ & $\begin{array}{l}19 \\
13 \\
15\end{array}$ & $\begin{array}{r}13 \\
6 \\
2\end{array}$ & \begin{tabular}{|l}
1978 \\
1978 \\
1978
\end{tabular} & $\begin{array}{l}04 \\
05 \\
07\end{array}$ & $\begin{array}{l}20 \\
13 \\
15\end{array}$ & $\begin{array}{l}18 \\
24 \\
22\end{array}$ & $\begin{array}{l}1 \\
1 \\
1\end{array}$ & $\begin{array}{r}0.11 \\
.07 \\
.04\end{array}$ & $\begin{array}{r}0.15 \\
.10 \\
.10\end{array}$ & $\begin{array}{r}0.17 \\
.13 \\
.22\end{array}$ & $\begin{array}{r}0.22 \\
.22 \\
.39\end{array}$ & $\begin{array}{r}0.49 \\
.54 \\
.57\end{array}$ & $\begin{array}{r}0.60 \\
1.24 \\
.70\end{array}$ & $\begin{array}{r}0.61 \\
1.24 \\
.70\end{array}$ & $\begin{array}{l}2 \\
2 \\
1\end{array}$ & $\begin{array}{l}1978 \\
1978 \\
1978\end{array}$ & $\begin{array}{l}04 \\
05 \\
07\end{array}$ & $\begin{array}{l}19 \\
13 \\
15\end{array}$ & $\begin{array}{l}19 \\
15 \\
18\end{array}$ & $\begin{array}{l}35 \\
55 \\
25\end{array}$ & $\begin{array}{l}1.31 \\
1.64 \\
1.45\end{array}$ & $\begin{array}{l}8.70 \\
13 \\
10\end{array}$ & \\
\hline
\end{tabular}



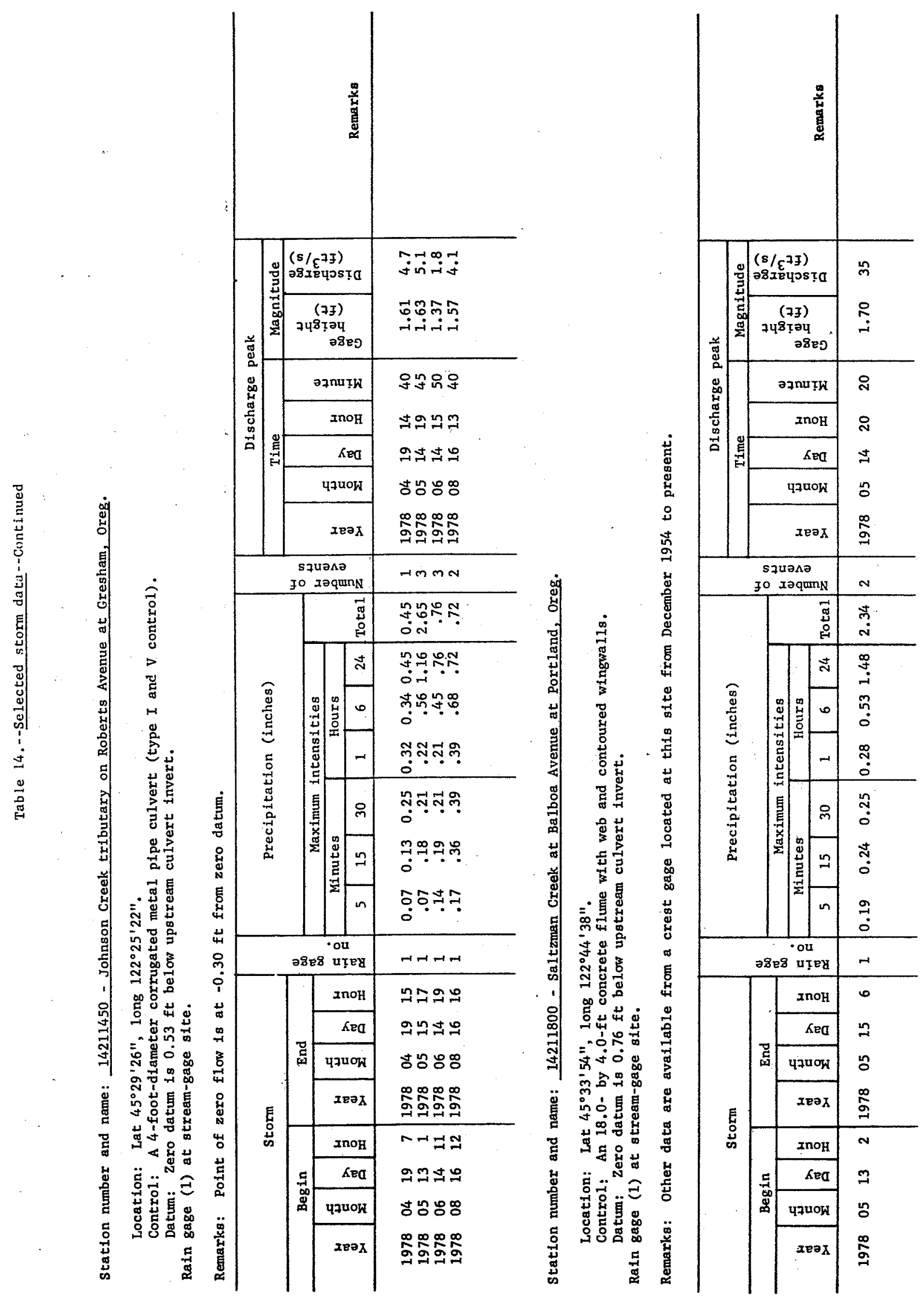

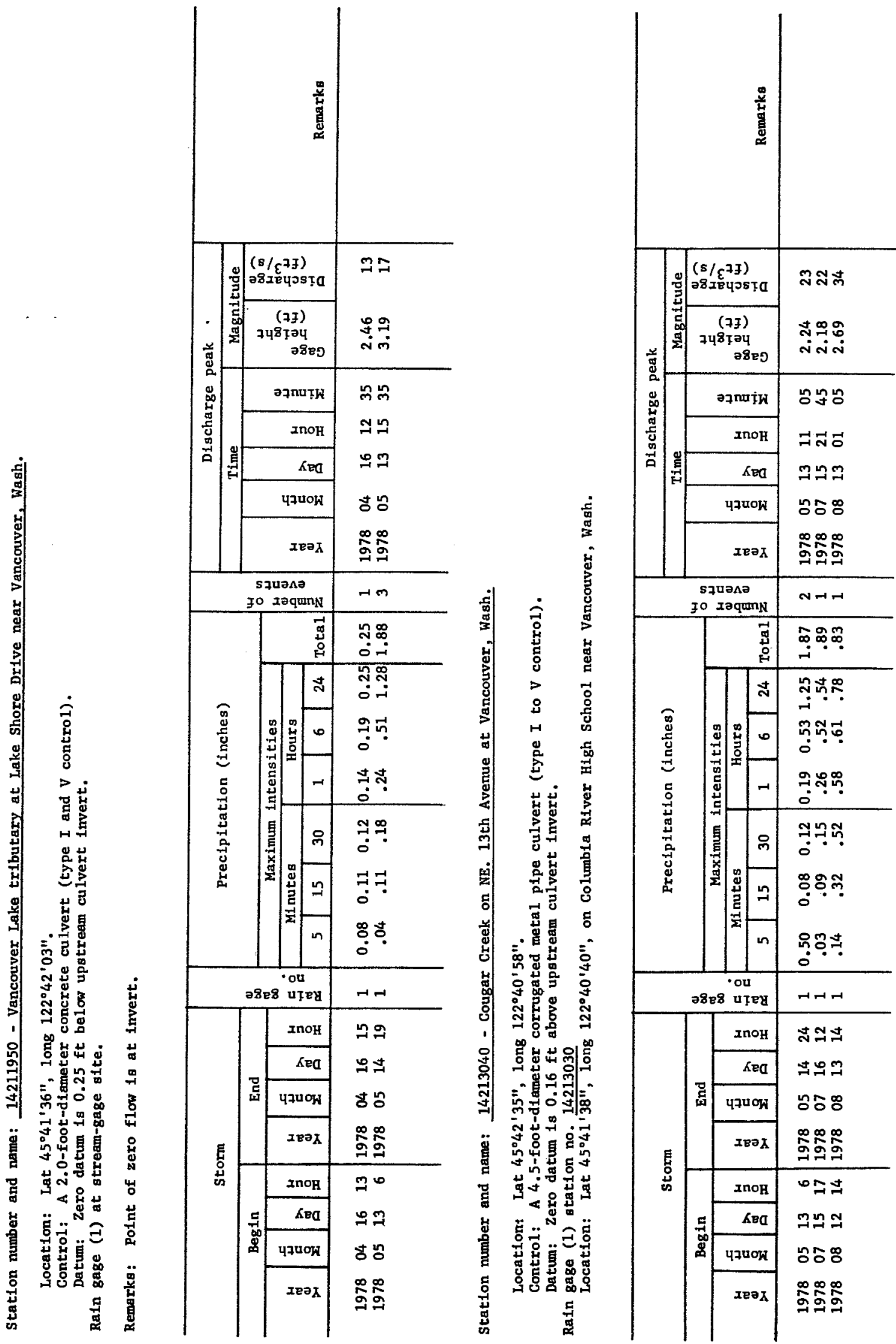


\section{SELECTED REFERENCES}

Allison, I. S., 1978, Late Pleistocene sediments and floods in the Willamette Valley: The Ore Bin, v. 40, nos. 11 and 12 .

Anderson, D. G., 1970, Effects of urban development on floods in northern Virginia: U.S. Geological Survey Water-Supply Paper 2001-C, 22 p.

Brown, S. G., 1963, Problems of utilizing ground water in the west-side business district of Portland, Oregon: U.S. Geological Survey WaterSupply Paper 1619-0, 42 p.

Dawdy, D. R., Lichty, R. W., and Bergmann, J. M., 1972, A rainfa11-runoff simulation model for estimation of flood peaks for small drainage basins: U.S. Geologica1 Survey Professional Paper 506-B, 28 p.

Dempster, G. R., Jr., 1974, Effects of urbanization on floods in the Dallas, Texas, metropolitan area: U.S. Geological Survey Water-Resources Investigations $60-73,51 \mathrm{p}$.

Hogenson, G. M., and Foxworthy, B. L., 1973, Ground water in the East Portland area, Oregon: U.S. Geological Survey Water-Supply Paper 1793, 78 p.

Laenen, Antonius, and Solin, G. L., 1978, Rainfa11-runoff data for selected basins, Portland, Oregon, and Vancouver, Washington, 1973-77: U.S. Geologica1 Survey Open-File Report 78-291, 48 p.

Mundorff, M. J., 1964, Geology and ground-water conditions of clark County, Washington, with a description of major alluvial aquifers along the Columbia River: U.S. Geologica1 Survey Water-Supply Paper 1600, 268 p.

National Oceanic and Atmospheric Administration, 1973a, Precipitationfrequency atlas of the Western United States, NOAA Atlas 2, volume IX Washington: Silver Spring, Md。, 43 p.

1973b, Precipitation-frequency atlas of the Western United States, NOAA Atlas 2, volume X - Oregon: Silver Spring, Md., 43 p.

Phillip, J. R., 1954, An infiltration equation with physical significance: Soil Science Society American Proceedings, v. 77, p. 153-157.

Putnam, A. L., 1972, Effect of urban development on floods in the piedmont province of North Carolina: U.S. Geological Survey Open-File Report, 87 p.

Sherman, L. K., 1932, streamflow from rainfa11 by the unit hydrograph method: Engineering News Record, v. 108, p. 501-505.

U.S. Soil Conservation Service, 1975, Urban hydrology for small watersheds: U.S. Department of Agriculture Technical Release 55, 92 p. 
U.S. Weather Bureau, 1955, Rainfa11 intensity-duration-frequency curves for selected stations in the United States, Alaska, Hawaiian Islands, and Puerto Rico: U.S. Weather Bureau Technical Paper 25.

1963, Maximum recorded United States point rainfall for 5 minutes to 24 hours at 296 first-order stations: U.S. Weather Bureau Technical Paper 2 (revised), $56 \mathrm{p}$.

U.S. Water Resources Counci1, rev. 1977, Guidelines for determining floodflow frequency: Bulletin 17A of the Hydrology Committee.

Wisler, C. 0., and Brater, E. F., 1959, Hydrology (2d ed.): New York, John Wiley, $408 \mathrm{p}$. 
